\title{
GESTÃO COM PESSOAS - Gestão, COMUNICAÇÃO e Pessoas: Comunicação como Competência de Apoio para a Gestão alcançar Resultados Humanos
}

Tese de Doutorado apresentada ao Programa de Pós-graduação em Ciências da Comunicação, Área de Interfaces Sociais da Comunicação, Linha de Pesquisa: Políticas e Estratégias de Comunicação da Escola de Comunicações e Artes da Universidade de São Paulo- USP, como exigência parcial para obtenção do Título de Doutora em Ciências da Comunicação, sob a orientação da Prof. ${ }^{a}$ Dra Sidinéia Gomes Freitas.

São Paulo 
ISABEL MACARENCO

\section{GESTÃO COM PESSOAS - Gestão, COMUNICAÇÃO e Pessoas: Comunicação como Competência de Apoio para a Gestão alcançar Resultados Humanos}

Tese de Doutorado apresentada ao Programa de Pós-graduação em Ciências da Comunicação, Área de Interfaces Sociais da Comunicação, Linha de Pesquisa: Políticas e Estratégias de Comunicação da Escola de Comunicações e Artes da Universidade de São Paulo- USP, como exigência parcial para obtenção do Título de Doutora em Ciências da Comunicação, sob a orientação da Prof. ${ }^{a}$ Dra Sidinéia Gomes Freitas. 
MACARENCO, Isabel.

GESTÃO COM PESSOAS - Gestão, COMUNICAÇÃO e Pessoas: Comunicação como Competência de Apoio para a Gestão alcançar Resultados Humanos / Universidade de São Paulo - USP, Isabel Macarenco. São Paulo, 2006, 233 pág.

1. Ciências da Comunicação 2. Interfaces Sociais da Comunicação do Curso de Ciências da Comunicação. 3. Gestão com Pessoas 


\section{INTERFACES SOCIAIS DA COMUNICAÇÃO DO CURSO DE CIÊNCIAS DA COMUNICAÇÃO}

Tese apresentada em ___ _ _ _ _ de 2007 como requisito parcial para a obtenção do grau de Doutor em Ciências da Comunicação pela banca formada pelos professores:

NOTA ( ) aprovado ( ) reprovado

Presidente e Orientadora: Profa. Dra. Sidinéia Gomes Freitas

Assinatura

Prof. Dr.

Assinatura

Prof. Dr.

Assinatura

Prof. Dr.

Assinatura

Prof. Dr.

Assinatura 


\section{Agradecimentos}

À Prof ${ }^{a}$ Dra. Sidinéia Gomes Freitas pela orientação, por ter me permitido ser sua aprendiz, amizade e consideração, e pelo estímulo às idéias inovadoras e coragem para expressá-las.

Á Prof ${ }^{a}$ Dra. Margarida Maria Krohling Kunsch por seu comprometimento com o universo acadêmico, pela indicação bibliográfica, e organização das idéias no exame de qualificação.

Ao Prof ${ }^{o}$ Dr. Fernando César Almada Santos por seu cuidado e propósito construtivo ao apresentar suas recomendações e sugestões.

A minha estimada amiga Maria de Lurdes Zamora Damião pelo apoio, por idéias compactuadas, suporte técnico, compartilhamento nas pesquisas e por ser presente.

Á Prof ${ }^{a}$ Denise Fabretti Moraes pelo apoio na Língua Portuguesa e profissionalismo.

Á existência por me conduzir pelos caminhos da ética, transparência e do amor. 
Dedico a meus pais a vida que gentilmente me ofereceram, a meus filhos por demonstrarem que possuo a magia de gerar vida, e à vida, que por meio de seus caminhos desencontrados, me fez tornar uma buscadora de mim. 
Beber a vida num trago, e nesse trago Todas as sensações que a vida dá Em todas as suas formas [...] .

Fernando Pessoa 


\section{RESUMO}

MACARENCO, Isabel, GESTÃo COM PESSOAS - Gestão, COMUNICAÇÃo e Pessoas: Comunicação como Competência de Apoio para a Gestão alcançar Resultados. São Paulo, 2006. 233 p. Tese (Ciências da Comunicação) Universidade de São Paulo - USP, 2006.

A gestão de pessoas é um conceito a ser aprendido nas organizações. A nova aprendizagem indica um caminho a ser trilhado pela administração de recursos humanos e por gestores para construção de uma visão ampliada de "competência” aplicada ao desenvolvimento do potencial do Ser Humano, envolvendo as suas capacidades de pensar, sentir e agir; a introdução dos conceitos de convivencialidade; a comunicação autêntica; a inteligência social, e o alinhamento entre conhecimento e sabedoria. O modelo proposto para gestão COM pessoas refere-se a uma visão inovadora da comunicação como competência de apoio para o grande desafio de administração de recursos humanos - gerar resultados humanos. Para alcançar resultados humanos é preciso ir além dos resultados econômicos almejados pelas organizações e pode ocorrer a partir de uma readequação da idéias e conceitos sobre o trabalho compreendido além de um meio para sobrevivência, mas como uma oportunidade de transformação de seres humanos, que podem aprender sobre conduta humana a partir dos cinco A' s - Abertura, Autenticidade, Anseio pela Inteireza, Atitude e Autoridade Interna.

Palavras-chave: comunicação, convivencialidade, gestão, pessoas, resultados humanos. 


\section{ABSTRACT}

MACARENCO, Isabel, MANAGEMENT WITH PEOPLE - Management, COMMUNICATION and People: Communication as Ability of Support Management to reach Results. São Paulo, 2006. 233 p. Tese (Ciências da Comunicação) Universidade de São Paulo - USP, 2006.

The management of people is a concept to be learnt at organizations. The new learning indicates a path to be followed by human resources administration and by managers for the construction of a broad view of competence applied to the development of the human being potential, involving the abilities of thinking, feeling and acting; an introduction of living-togetherness concept; the authentic communication; the social intelligence, and the lining of knowledge and wisdom. The proposed model for management with people refers to an innovative vision of communication as a support competence for the big challenge of human resources administration - provide human results. In order to achieve human results it is needed to go beyond the economic results aimed by organizations and it may happen upon a reorganization of ideas and concepts about work understood beyond a means of survival, but as a transformation opportunity of human beings, who can learn about human behavior from these five topics - Willingness, Authenticity, Desire for the Whole, Attitude and Internal Authority.

Key-words: communication, human results, living-togetherness, management, people. 


\section{LISTA DE QUADROS}

Quadro I- Administração Científica e Perspectivas Humanas 43

Quadro II- Teorias Administrativas e Nomenclatura da Relação Trabalho/Trabalhador 49

Quadro III- Recursos Humanos no Momento Presente 58

Quadro IV- Concepção Teórica, Clássica e Contemporânea da Comunicação 130

Quadro V- Interesses Históricos em Comunicação Organizacional 131

Quadro VI - Programas de Pesquisa em Comunicação 132 


\section{LISTA DE TABELA}

Tabela 1 - CHAVE 


\section{LISTA DE FIGURAS}

Figura I - Repercussões do alinhamento da Razão à Emoção 171

$\begin{array}{ll}\text { Figura II- Fluxo de Comunicação } & 178\end{array}$

Figura III- Roda da Comunicação 182

Figura IV- “Modelo em Construção” para Gestão COM Pessoas 189

Figura V- RH como Resultados Humanos 193

Figura VI - Recursos e Resultados Humanos

202 


\section{SUMÁRIO}

$\begin{array}{ll}\text { INTRODUÇÃO } & 01\end{array}$

$\begin{array}{ll}\text { A Escolha do Tema } & 07\end{array}$

$\begin{array}{ll}\text { A Justificativa } & 14\end{array}$

O Problema de Pesquisa

A hipótese $\quad 22$

Objetivo Geral 23

Objetivos Específicos $\quad 23$

A Relevância do Estudo $\quad 24$

As Peculiaridades do Estudo $\quad 26$

$\begin{array}{ll}\text { Sobre a Metodologia } & 28\end{array}$

Caracterização da Pesquisa $\quad 29$

Tipo e Modo de Investigação 30

A Abertura Disciplinar 31

1- FUNDAMENTAÇÃO TEÓRICA

1.1- A Herança da Administração Gerencial 32

1.1.1- Precursores da Administração: Taylor, Ford e Fayol 35

1.1.2- Grandes Movimentos da Era Moderna e a Natureza do Gerenciamento 42

1.1.3- Racionalização das Práticas de gestão 44

1.1.4- A Administração de Recursos Humanos 46

1.2- O Estudo de Hawthorne (De 1924 a 1932) 58

1.2.1- O Experimento na Empresa Western Electric 60

1.2.2- Considerações Relevantes sobre a Pesquisa $\quad 68$

1.2.3- Observações sobre a Ação dos Supervisores

1.2.4- O Experimento e as Considerações Relevantes para a Tese 73

1.3- Abordagem Comportamental da Administração e o Lado Humano na

$\begin{array}{ll}\text { Empresa } & 76\end{array}$

1.3.1- Teoria Comportamental da Administração 77

1.3.2- Teoria $X$, Teoria Y e Teoria $Z$

1.3.3- Repercussões das Proposições sobre a Motivação Humana 80 
1.3.4- Revisitando McGregor e Revelando o Lado Humano

1.3.5- A Aceitação/Rejeição do Estudo das Relações Humanas 84

1.3.6- Comunicação para as Mudanças no Lado Humano nas Organizações 87

1.4- Análise do Trabalho $\quad 92$

1.4.1- A Transformação no Significado do Trabalho 93

1.4.2- Repercussões da Qualidade Total 97

$\begin{array}{ll}\text { 1.4.3- Modelo da Descartabilidade } & 100\end{array}$

1.4.4- Ritmo do Capital e do Trabalho 106

1.4.5- Trabalho e Reprodução do Capitalismo 109

1.4.6- Trabalho e Ser Humano 112

1.4.7- Gestão da Comunicação e Subjetividade 115

1.5- Ação no Trabalho 119

1.5.1- Definição de Competência em Estudo e a Inclusão da CHAVE 120

1.5.2- O Paradoxo Educacional do Capital Humano 123

1.5.3- O Roteiro da Competência para a Empresa Competitiva 124

1.5.4- Modelo de Gestão de Pessoas baseado em Competências 127

1.6- Comunicação e Organizações 129

1.6.1- Metáforas da Comunicação e Organização 129

1.6.2- Aspectos Relacionais da Comunicação 134

1.6.3- Perspectivas de Mudanças na Comunicação 140

1.7- Comunicação na Organização 146

1.7.1- Comunicação para Gerenciamento 147

1.7.2- Comunicação Autêntica para Comunicação Gerencial 148

1.7.3- A comunicação na Prestação de Serviços 152

1.7.4- Comunicação para Administração de Recursos Humanos 153

1.8 - Atração de Recursos Humanos com Potencial para Desenvolvimento 153

1.8.1- Avaliação de Performance e Retenção de Talentos 156

1.8.2- Desenvolvimento do Capital Intelectual 157

1.9- Aprendizagem Organizacional 159

1.9.1- Compreensão para Aprender $\quad 161$ 
2- Gestão COM Pessoas - Gestão, COMUNICAÇÃO e Pessoas 161

2.1- A Gestão 166

2.1.1- Contexto de Ameaça Estrutural ao Trabalho 166

2.1.2- A Subjetividade na Gestão $\quad 168$

2.1.3- Dificuldade dos Gestores $\quad 170$

2.1.4- Sobre o Desconforto de Aprender 172

2.1.5- Aprender para Ensinar $\quad 174$

2.1.6- Gestores Aprendendo com Administração de Recursos 174

2.2- A Comunicação 178

2.2.1- Comunicação Para uma idéia Com os Demais 179

2.2.2- Comunicação como Competência de Apoio 180

$\begin{array}{ll}\text { 2.2.3- Convivencialidade Aplicada } & 183\end{array}$

2.2.4- Interação pelo Diálogo 184

2.2.5- Construção do Tripé: Realidade, Afinidade e Comunicação 187

2.3- Gestão COM Pessoas 188

2.3.1- Responsabilidade por Resultados Humanos 192

2.3.2- O Trabalho Emocional na Administração de Recursos Humanos 194

2.3.3- Inteligência Social para Alcançar Resultados Humanos 196

2.3.4- Administração de Recursos Humanos e Inteligência Social 199

CONSIDERAÇÕES FINAIS

BIBLIOGRAFIA $\quad 215$

GLOSSÁRIO $\quad 225$ 


\section{INTRODUÇÃO}

A construção do conhecimento ocorre a partir da capacidade do homem de pensar a realidade física, de sentir afinidade com idéias, pessoas e lugares (considerando certa distância, boa ou ruim), de agir em relação ao mundo físico e da capacidade de estabelecer uma comunicação de acordo com a realidade e afinidade.

A inter-relação dessas capacidades mostra evidente dependência uma da outra, apesar de muitos ignorarem a sua existência ou aplicação. Com o conhecimento sobre essas capacidades podemos ir até certo ponto, mas com a combinação delas, desenvolve-se a capacidade de compreensão.

O conhecimento não pode ser guardado em caixinhas ou compartimentalizado. A sua transformação em saber acontece a partir de um diálogo interdisciplinar, em uma abertura a novos campos de estudos e novas descobertas.

As novas relações globais baseadas na competitividade colocam um desafio para a ciência da comunicação, pois grandes redes de informação e comunicação confundem o campo conceitual e a amplitude da noção de comunicação.

O comando das organizações de capital privado está sob controle de acionistas, denominados mais comumente, em administração, de Stakeholders ${ }^{1}$. O centro da atenção é o mercado consumidor; as pessoas empregadas nessas organizações intermedeiam relações em rede e enquanto pessoas jurídicas devem comunicar sobre a visão, os valores e seus objetivos de interesses privados. Nesse sentido ocorre um distanciamento entre as forças sociais em movimento nas relações globais e a adoção de um modelo de comunicação empresarial que promova a administração interna desse complexo fluxo de comunicação, que definirá o vínculo das empresas com a sociedade.

Teorias unificantes difundidas por estudiosos da comunicação em países do Primeiro Mundo são confrontadas com as ambivalências da realidade local de cada país e do mercado global. A realidade local requer uma organização do cotidiano que privilegie a vida democrática e, conseqüentemente, o desenvolvimento.

\footnotetext{
${ }^{1}$ O termo "stakeholders" foi criado para designar todas as pessoas ou empresas que, de alguma maneira, são influenciadas pelas ações de uma organização.
} 
A comunicação como inteligência empresarial exige uma nova postura. Provavelmente, as empresas e as entidades - com parceria de importantes universidades brasileiras e de grupos de pesquisa estarão investindo no futuro para estabelecer um novo paradigma. Nele, a experiência e a instituição, como acontece em todo campo científico, não serão descartadas; pelo contrário, a investigação, a pesquisa, a sistematização de dados, deverão se impor como instrumentos de legitimação, de ações, estratégias e canais de comunicação. (BUENO 2003: 16).

A comunicação, como inteligência empresarial aplicada à construção da sua realidade e da alavancagem de resultados internos e externos, gera condições favoráveis à competitividade e apresenta-se como uma competência de apoio à organização, vital para clareza da estratégia organizacional adotada, definição das competências organizacionais requeridas para o sucesso do negócio, definição das competências individuais desejadas, (enquanto conhecimentos, habilidade e atitudes que o profissional deve aplicar ao trabalho), capacidade para tomada de decisão e relacionamento.

Assim, uma nova prática de relações para diminuir distâncias entre seus públicos colaboradores, acionistas, imprensa, fornecedores, clientes, internet, etc, requer a introdução de conceitos como parceria e convivencialidade, para melhorar a compreensão do processo de mudança constante e de adaptações necessárias.

As novas ações devem comunicar uma busca de equilíbrio entre os diversos níveis de interesses, e alguns indicadores de garantia da competitividade referem-se à constante revisão das competências consideradas essenciais ao negócio, à gestão dos profissionais, às condições favoráveis à aprendizagem e desenvolvimento de competências que agreguem valor, mudanças na estrutura organizacional, inovação e custos. Para Bueno (2003), "surgem, como decorrência, a figura do cliente interno, uma forma democrática e inteligente de enxergar o funcionário, e a do fornecedor - parceiro, que deve estar comprometido com os produtos e resultados da empresa".

As competências propaladas referem-se, segundo Leboyer (2000), aos repertórios de comportamentos e capacitações que algumas pessoas e organizações dominam melhor do que outras, fazendo-as eficazes em uma determinada situação. Portanto, o domínio de determinadas competências faz com que profissionais e organizações façam a diferença no mercado. As mudanças contextuais e o nível de complexidade do ambiente externo exigiram das empresas um alinhamento das práticas de Administração de Recursos Humanos, que ao centralizar e ser a área reconhecidamente responsável por processos de pessoal, se orientou internamente por linhas e correntes de gerenciamento definidos pelas escolas de 
administração, cujas grandes correntes focaram as ações organizacionais na Estruturação Organizacional, no Desenvolvimento Organizacional, Qualidade Total e Reengenharia.

As novas práticas de Administração de Recursos Humanos resultaram em uma redistribuição de responsabilidades, pelo desenvolvimento das pessoas, aos gestores diretos, surgindo a necessidade de capacitação desses gestores para que saibam agir dentro de uma nova ordem, baseada na gestão integrativa, com foco no negócio, no mercado/cliente, no conhecimento das pessoas e na melhoria de processos.

As ações organizacionais não se apresentam como seqüência contínua de fazeres, conforme o planejado, assim como a comunicação, como competência de apoio, não se refere apenas ao intercâmbio de idéias entre dois indivíduos. Quanto à idéia da linha de comunicação representada por um trajeto, através do qual a comunicação era emitida de uma direção à outra, essa também foi substituída por uma idéia de rotas alternativas para se dirigir aos “outros”, em novas seqüências de ações e autoridade.

Ao se afirmar que a empresa atua em interação com o meio externo, abriu-se um caminho para o surgimento da visão sistêmica da organização, que a vê como parte de um sistema amplo e dinâmico, que a influencia, mas também é influenciado por ela. O sistema representa o complexo do "todo" organizado, uma combinação de partes. A Teoria dos Sistemas tem papel importante no pensamento científico, pois permite a integração dos conhecimentos das ciências físicas, biológicas e humanas e alguns de seus principais desdobramentos: a teoria da informação, a cibernética e a ecologia. Nesse sentido, para a administração não ocorreram apenas transformações físicas para adequação da produção, mas também envolveu a comunicação entre agentes e funcionários para desenvolver, produzir e entregar o produto ou serviço, com foco nas necessidades dos clientes.

O envolvimento das pessoas, para que elas se empenhassem no processo cooperativo de aprendizagem e resultados, culminou na necessidade de desenvolvimento de competências para que profissionais tivessem condições de realizar suas atividades agregando valor ao produto ou serviço.

Para acompanhar esse movimento as novas práticas de gestão de pessoas também mudaram. Mesmo que essas mudanças não estejam presentes de forma unânime nas organizações, elas refletem um novo modo de pensar e agir dentro das organizações. Apesar de pouco integrativo discute-se mais sobre um novo pensar e agir, mas quase nada sobre a capacidade de sentir. 
Chama a atenção nessas novas exigências para a Administração de Recursos Humanos, a necessidade de mudança de atitudes nas pessoas, enquanto dirigentes, administradores, gestores ou profissionais de linha de frente.

Uma nova ordem requer sensibilidade para saber posicionar-se na busca de uma condição de afinidade com a realidade. Perceber ou não as necessidades que a nova realidade impõe afeta drasticamente a compreensão do indivíduo em sentir-se como parte integrante de um processo mais amplo. Há um incremento de projetos nas empresas para identificar e reter talentos que possam fazer a diferença; aqueles com potencial para desenvolvimento de competências alinhadas às estratégias organizacionais. Ninguém está só nesse processo. Quando se desenvolve uma visão clara dessa alternância entre o Eu e o Outro, a aprendizagem faz sentido e a empresa se apóia no compartilhamento de conhecimentos técnicos e relacionais para reter pessoas.

As dimensões do ser não podem ser esquecidas. Ser é uma categoria de identidade própria e referem-se ao nome, a uma profissão, características físicas e um papel no contexto.

(...) quando falamos do ser humano não podemos separá-lo de seu mundo. $\mathrm{O}$ homem, portanto, é um ser-no-mundo. E nesse mundo, existe sempre em relação aos seus semelhantes. $O$ que chamamos de mundo é a realidade humana. O homem habita o mundo, constrói e destrói um ambiente relacionado a ele próprio - um mundo humano. A realidade não é mais do que o conjunto de percepções, relacionamentos e realizações das pessoas. A experiência é o resultado do confronto entre o que o homem deseja e o que as limitações de seu corpo lhe permitem conseguir [...] Assim a visão de mundo de um indivíduo resulta de um jogo entre as sua necessidades e o modo como consegue satisfazê-las. Essa satisfação acontece por meio de objetos e das pessoas com que ele consegue se relacionar. (MARIOTTI 1999: 113).

Portanto, não se trata de modismo, mas é necessário discutir nas empresas, por iniciativa da Administração de Recursos Humanos, os aspectos inerentes ao conceito de convivencialidade, que devem servir de ponte para viabilização das transformações organizacionais e individuais.

A introdução dessa temática deve gerar enorme impacto nos resultados organizacionais e humanos porque abre um espaço para que aflore a expressão dos potenciais humanos. Para Agostinho, Bauer e Predebon (2002), “a convivencialidade é a atitude de reconhecer o outro com quem nos relacionamos como um "legítimo outro". A convivencialidade busca transcender o utilitarismo em que o "outro representa apenas o uso que se possa fazer dele. Isso se aplica às relações que mantemos conosco mesmos, com as demais pessoas, a sociedade, o mercado e a natureza." 
O modelo de sociedade industrial trouxe o racionalismo linear e simplificador, muito útil para resolver problemas com rotinas e funcionamento das máquinas, mas não serve para resolver problemas complexos, que envolvem as emoções e a totalidade do ser humano. Como nas atividades humanas tudo resulta da interação de fatores emocionais e racionais é preciso aprender a lidar com essas duas polaridades, para saber lidar com a complexidade.

É importante enfatizar que as pessoas tendem a desenvolver uma mentalidade utilitarista e a globalização das comunicações trouxe a valorização dos meios de comunicação para manter um relacionamento sistemático e transparente com seu público.

Na concepção de uma sociedade mais contemporânea as organizações visam o lucro, mas isso não é tudo, há a necessidade de fixar um elo com esse mundo externo, de modo a garantir a valorização da marca, da imagem, das pessoas e da responsabilidade social.

$\mathrm{Na}$ sociedade contemporânea a comunicação é integrada e as organizações surgem como canais de comunicação com a sociedade. A comunicação estimulou o homem a buscar razões para o trabalho e sinalizou com a perspectiva de consumo como um caminho para sua realização, mas a contemporaneidade, o contexto desumano e o desemprego estrutural revelaram um grande dilema com relação à figura do indivíduo e sua posição na sociedade e nas organizações, pois ele entra em crise pelas coisas mal resolvidas e promessas não cumpridas. Esse ser, que diante da crise revela uma emoção como parte inerente à vida, contraria todas as teorias de motivação quando passa a lutar pela realização de desejos e não apenas pela satisfação de necessidades das necessidades. É por isso que as pessoas estudam, consomem, viajam, fumam, se estressam, adoecem, sofrem de síndromes de pânico...

(...) o 'desencantamento' do mundo é um processo que atravessa os tempos modernos. [...] Traduz-se em formas de sociabilidade, modos de organizar o trabalho e a produção, relações, processos e estruturas de dominação e apropriação, alienação e emancipação. (IANNI 2000:263).

Há necessidade de que profissionais de Administração de Recursos Humanos concentrem-se não apenas em conceitos ou modismos que passam, mas na construção de uma afinidade com o que há por detrás deles.

Ribeiro (2006) argumenta que as únicas coisas que não passam são estas expectativas dos empregados: desejo de justiça, desejo de valorização e reconhecimento, desejo de transparência, desejo de evoluir, ter boa liderança, ter bom ambiente de trabalho e ter seu trabalho dignificado. As competências da Administração de Recursos Humanos agregarão valores na medida em que revelem as capacidades dos profissionais da área para agir com 
responsabilidade, mobilizar recursos e comunicar para as pessoas, em todos os níveis de relacionamento, sobre esse maior desafio atual: como satisfazer essas expectativas dos funcionários e ter parâmetros para apontar/eliminar/diminuir os efeitos dos restritores que possam impedir esse resultado humano.

Não se deve aceitar e conviver com elementos predominantes da Teoria $\mathrm{X}$ de McGregor, ainda presentes em plena era do capital intelectual, que privilegia a inteligência das pessoas que fazem a organização. Não há de se aceitar a ação de gestores que alimentam uma realidade doentia, na qual o trabalhador é reduzido a sucata, algo descartável ou embalado para destruição. Os gestores também deverão rever seus conceitos e competências. Ninguém está isento desse processo.

Nas organizações os Administradores de Recursos Humanos controlam os processos de seleção, programas de treinamento e sistema de avaliação de desempenho dos trabalhadores e geralmente, as decisões são tomadas visando obtenção de alto nível de desempenho. A utilização de instrumentos para seleção orienta no sentido da maximização da probabilidade de adequação do indivíduo ao ambiente de trabalho. Os efeitos bastante óbvios de programas de treinamento sobre o comportamento dos funcionários é o aprimoramento das habilidades necessárias para realização de tarefas com sucesso. O aperfeiçoamento dessas habilidades aumenta o potencial de desempenho de alto nível. Considera-se de forma simplificada, que a concretização desse potencial é uma questão de motivação. A avaliação de desempenho é a análise da contribuição do desempenho de um indivíduo como base para as decisões sobre recompensas e promoções.

Um dos indicadores de desempenho empresarial, talvez aquele considerado o mais importante no atual contexto de mercado, está na sua capacidade de atrair, desenvolver e reter pessoas talentosas. A integração das diversas funções da Administração de Recursos Humanos, apoiada por um processo de gestão efetivo, é o primeiro passo para geração de resultados. Os profisssionais que atuam em recrutamento, seleção, treinamento, desenvolvimento, avaliação de desempenho, carreira e remuneração precisam reconhecer a necessidade de mudanças também dentro da própria área e buscar caminhos os quais ajudem a conquistar espaços que ultrapassem os discursos que envolvem as novas denominações e responsabilidades associadas à área, a qual, com roupagem de inovação e avanço, são apresentadas em manuais, congressos e seminários como "RH do Operacional ao Estratégico". 
O maior esforço demandado da Administração de Recursos Humanos não está na forma ou denominação que deve utilizar para se apresentar no contexto da exterioridade. A transformação deve vir de uma auscultação interna, na procura de dificuldades na sua organização e que possam estar impedindo as pessoas de alcançarem uma compreensão mais ampla sobre seus talentos e limitações, rumo ao desenvolvimento de conhecimentos, habilidades e atitudes para trabalhar, se relacionar e conviver.

Tornou-se urgente para a Administração de Recursos Humanos aprender uma nova linguagem para espelhar sua competência de lidar com a busca e o tratamento das causas que possam gerar empecilho à expressão de potencial e vida nas empresas.

Se a Teoria $\mathrm{X}$ ainda está presente nas organizações o trabalho de Administração de Recursos Humanos não é efetivo, não se trata de corrigir o problema, mas saber qual é o problema e quais são as causas que impedem essa mudança de ação de dirigentes e gestores. Esse é um grande desafio para Administração de Recursos Humanos e, para tanto, os profissionais da área e gestores devem usar a comunicação de forma a promover a inteligência, para buscar um acordo de pensamentos e ideais com os demais membros da organização. Fleury e Fleury (2000) complementam que na economia baseada no conhecimento, o que mais adiciona valor são as atividades inteligentes. As atividades rotineiras, manuais, passam a ser, cada vez mais, menos importantes". Entende-se, portanto, que não se trata de um realinhamento de procedimentos ou das práticas de gestão; Administração de Recursos Humanos deve comunicar para seu grande público sobre a importância do desenvolvimento das pessoas, como pré-requisito para se atingir o desenvolvimento do profissional, afinal é o poder do cérebro das pessoas que contribui para o nível das organizações. Conforme Stewart (1998: 26), "na era do capital intelectual, as partes mais valiosas do trabalho tornaram-se essencialmente humanas: sentir, julgar, criar e desenvolver relacionamentos".

\section{A Escolha do Tema}

O tema - Gestão, COMUNICAÇÃO e pessoas - refere-se à forma como a gestão de pessoas tem sido introduzida no meio acadêmico e de trabalho, quase como uma versão mais atual de Administração de Recursos Humanos. 
Sabe-se que a valorização do funcionário como diferencial competitivo é um dos pontos-chave da modernização administrativa e está presente nos discursos dos profissionais de Recursos, mas não quer dizer que ocorra na maioria das empresas.

As empresas que procuram estruturar as idéias sobre a problemática do relacionamento humano têm claro que aqueles que tomam decisões sobre gestão de pessoas estão estimulando comportamentos coerentes com a necessidade de desenvolvimento de competências para os objetivos organizacionais. Então o termo gestão de pessoas não é uma substituição da administração de RH. A gestão procura ressaltar o caráter de ação e o foco da atenção são as pessoas.

Com a contribuição de Fisher (2001), verifica-se que os termos administração e gestão são utilizados como sinônimos, mas em geral considera-se "gestão" uma ação para a qual há menor grau de previsibilidade sobre o resultado do processo a ser gerido. Nessa visão, usar o termo gestão pode significar resgatá-lo do caráter humano e sobrepô-lo ao aspecto técnico no âmbito do relacionamento entre pessoas e empresas. Então se o conceito de administração fora construído para favorecer a otimização de recursos, nos dias de hoje a questão da otimização vem sendo colocada à prova porque essa não é mais a era da produção massificada e das grandes máquinas mecanizadas. Com o desenvolvimento dos recursos de informática e o uso de softwares cada vez mais avançados, os modelos de computadores e máquinas mais novos substituem completamente os anteriores e não se fala em "otimizar" a versão anterior.

Considerando que a gestão de pessoas é um conceito a ser aprendido por todos, a administração de recursos humanos deve tomar a frente desta questão e comunicar sobre o reconhecimento de um despreparo dos gestores para lidar com essas transformações e instituir a gestão COM pessoas, como uma alternativa para acelerar o desenvolvimento de novas competências, que busquem as causas que impedem a gestão COM pessoas, a fim de reconhecer que há problemas e desafios internos à área e querer fazer algo a respeito, acreditando-se na possibilidade de alcançar resultados humanos.

Assim sendo, a comunicação deve ser considerada uma competência de apoio para essa nova missão da administração de recursos humanos, e promover um acordo que seja comum ao discurso das pessoas: necessidade de desenvolvimento para situar-se no mundo de humanos. 
A comunicação para acionistas, para clientes, para funcionários de linha de frente e para os de apoio, não é uma ferramenta para modelar representações da mudança organizacional e das preocupações que acompanham o processo de mudança. Como competência de apoio, comunicação organizacional é um elemento facilitador que se entrelaça com idéias, posições e valores das pessoas, para uma articulação mais clara, mais concisa e mais viva possível do estado que se deseja para a organização desde já: no presente.

Os gestores COM pessoas podem criar esse senso de direção e as bases para a filosofia que servirão como bússola para dar rumo às ações organizacionais. A visão proporciona direção e revela a cultura organizacional, com a comunicação como competência de apoio à administração de recursos humanos, ensinará aos gestores sobre como contribuir para o desempenho da organização e buscar resultados humanos, a partir deles próprios. O segundo passo, que talvez seja o primeiro, ou quem sabe o único passo, é movimentar a energia dos membros da organização sobre necessidades, sonhos e desejos que devem ser despertados para que se alcance um propósito comum. Sobre esse propósito Bowditch e Buono (2006) afirmam:

(...) em certo sentido, isto é uma manifestação de um sonho da organização uma tentativa de dar asas à imaginação e de motivar as pessoas a repensarem as possibilidades da organização. Em condições ideais, a visão para uma organização ajuda a criar o desejo de uma mudança tornando o futuro potencial mais atraente que a realidade presente. (BOWDITCH e BUONO 2006:95).

Considerando-se que é um sonho, pode-se também acreditar na tentativa de dar asas à imaginação para as pessoas repensarem as possibilidades da existência.

Vale observar que essa articulação da visão é a revelação "sem véus" do plano de comando mais alto. Em nível gerencial os esforços de comunicação devem traduzir e comunicar essa visão por meio da declaração da missão das unidades de negócio e da filosofia a ser adotada para construção e revisão permanente dos princípios operacionais.

Como competência de apoio à administração de recursos humanos, a comunicação tem como desafio evitar a confusão de conceitos e idéias e estabelecer algumas prioridades para alcançar os resultados. Se os resultados que se buscam são os econômicos e os humanos, então deve estar claro para todos que isto é o que a organização está buscando alcançar. Espera-se uma comunicação de mão dupla, portanto os membros da organização devem ser incentivados a manifestar suas preocupações e quaisquer pensamentos a respeito da visão sobre o que impede a organização de atingir os resultados e como a percepção e sentimentos 
dos funcionários podem contribuir para se reverter situações restritoras às mudanças ou à falta de acordo.

A comunicação como competência de apoio às ações da administração de recursos humanos na capacitação de gestores deve envolvê-los nessa tarefa de construir uma massa crítica para promover aquilo que a organização está declarando e tentando realizar, principalmente sobre essa necessidade de cada um saber posicionar-se diante das evidências das mudanças, de desenvolver novas competências e de saber agir com responsabilidade para a construção de uma rede que acelere o processo de aplicação da Teoria Y de McGregor.

Fisher (2001: 20) afirma que "hoje o papel do homem no trabalho vem se transformando. Suas características mais humanas - o saber, a intuição e a criatividade - são valorizados. Temos de reconhecer que gerimos nossas relações com pessoas, não com recursos, o que demonstra a transição para uma realidade empresarial radicalmente diversa".

Portanto, todos profissionais que atuam influenciando diretamente na coordenação de pessoas (chefes, supervisores, gerentes) são administradores de recursos humanos e estão sendo considerados gestores de uma unidade quando assumem a responsabilidade de estimular o uso das capacidades individuais de sua equipe.

Para Lacombe (2005:19), “esses profissionais são responsáveis pelos resultados de sua área e os das pessoas que se encontram sob a sua subordinação; por distribuírem os trabalhos, planejar e controlar os resultados; por motivarem e avaliarem os subordinados e lhes dar feedback sobre seu desempenho; por decidirem sobre admissão, promoções e demissões; pela orientação e educação de novos empregados; pelo treinamento de seus subordinados e, sobretudo, por zelar pela segurança no trabalho de todo seu pessoal”.

Assim até um encarregado de equipe de um turno é um administrador de recursos humanos. A área de RH deve orientar e apoiar os gerentes e prestar-lhes serviços, mas a cada gerente cabe a administração dos recursos humanos da empresa. Para Lacombe (2005:20) "não se deve, porém, menosprezar a importância do Departamento de Recursos Humanos. A ele cabe não só o apoio, a orientação e a prestação de serviços centralizados, como também a sensibilização dos gerentes para a importância da equipe nos resultados. Cabe-lhe "educar" os gerentes para que eles, por sua vez, atuem como educadores de sua equipe; sugerir novas formas de administrar o pessoal, além de se manter informado sobre o "estado da arte" nos assuntos de recursos humanos, trazendo esses conhecimentos para a organização”. 
Torna-se importante salientar que muitos profissionais no cargo de comando não estão preparados para a "gestão" - esse conceito talvez nem tenha feito parte de sua educação formal ou da vivência profissional - eles podem ter aprendido que formar pessoas não é parte de suas atribuições, que isto cabe à área de RH. Porém observa-se que são esses gestores os responsáveis por educar para as novas necessidades, no dia a dia, e não necessariamente, encaminhar os subordinados para sessões de treinamento formal.

Ao avaliar resultados e dar feedback, se o objetivo é o desenvolvimento do potencial das pessoas, caberá ao gestor dar suporte técnico e comportamental ao seu pessoal. Logo o gestor é o exemplo, enquanto o espelho, e também educador, mas é também o aprendiz porque deve acreditar na perspectiva de aprendizagem contínua para todos, inclusive a sua, compartilhando informações e conhecimentos e aprendendo com os demais.

Entende-se que esses gestores devem ser capacitados por profissionais da área de RH, cuja competência vai além de dar apoio, orientação e prestação de serviços centralizados, pois se refere à sensibilização dos gestores para a importância da valorização das pessoas e de sua capacidade de contribuição para os resultados organizacionais, com base em seu desenvolvimento. A administração de recursos humanos tem como mais um desafio, "educar" os gestores para que eles atuem como educadores de seu grupo, capacitando-os sobre novas formas de gerir pessoas e estimular o desenvolvimento de seu potencial.

Para ensinar gestores e membros da organização, a administração de recursos humanos deve ser o exemplo, por isso deve aprender primeiro e depois, comunicar sobre a importância de se aprender sobre assuntos relacionados ao ambiente de transformações e novos paradigmas organizacionais, gestão, comunicação e pessoas.

Para aumentar o estímulo à reflexão e à percepção de que não há como "fechar os olhos" para a mudança na administração de recursos humanos e o papel do gestor, há uma importante contribuição de Vergara (2003), que afirma:

Outra questão crucial que não podemos deixar de atrelar à tecnologia, apesar de muitas opiniões contrárias, é o desemprego. No caso do Brasil, a relação tecnologia-desemprego não é muito evidente porque, ao contrário dos países ditos desenvolvidos, ainda não chegamos a um estágio de desenvolvimento tecnológico tal, que possamos abrir mão das tarefas realizadas pelas pessoas [...] por outro lado há oferta de emprego não preenchida, para pessoas que detêm certas habilidades e possuem tipos especiais, avançados, de informação [...] além do que se pode observar como há descompasso entre geração e distribuição de riquezas, nota-se que o elevado desenvolvimento tecnológico, de certa forma, convive com um baixo desenvolvimento pessoal, interpessoal e moral.(Vergara, 2003:21) 
Verifica-se que apesar de tanto desequilíbrio, não se trata de mal sem possibilidade de tratamento às causas de tantos incômodos. As ciências e a tecnologia, aplicadas às pesquisas, por um lado torna cada vez mais evidente a influência dos atos humanos e a sua contribuição para o desequilíbrio reinante em diversos níveis, por outro lado vem desenvolvendo a consciência do "estar-no-mundo", de Morin (1996), tornando evidente a existência de um processo complexo, cujo entendimento é fundamental para a compreensão do contexto atual. Trata-se de mudança de valores pessoais. Alguns denominam de pós-modernismo o sistema de valores que, diferentemente da ênfase ao crescimento econômico que caracterizou a moderna sociedade industrial, dá importância aos aspectos relacionados à qualidade de vida e ao equilíbrio do ser.

Deve-se investigar sobre esses valores considerando-se a polaridade inerente a eles; dois grandes focos orientam as ações de nações, profissionais e cidadãos no sentido de compreender e lidar com os fenômenos que regem a vida pessoal e profissional. Um primeiro foco orienta as pessoas que devam ter aprendido sobre motivação e maior participação pessoal, que é operacionalizado com o exercício de direitos, deveres e responsabilidades. Um segundo foco orienta as pessoas que acreditam na possibilidade do desenvolvimento do potencial humano, logo, nesse caso há uma orientação para a transformação das pessoas e os valores referem-se à interioridade do ser humano e à necessidade de explorar os caminhos do auto-conhecimento, o que não é tão comum à administração.

O conhecimento e a revolução tecnológica não transformaram apenas os processos de trabalho e produção, alteram-se também os padrões de sociabilidade e a forma como a coletividade se sustenta, apoiada em rede de informações, com técnicas e procedimentos informatizados: internet, telefonia, auto-atendimento, robótica e cibernética. O homem continua vinculado à máquina. No período da revolução industrial e dos ensinamentos da administração científica ao homem foi relegada a condição de "apêndice da máquina", pois ele aprendeu a se adaptar à condição socialmente imposta. Uma nova configuração histórica fez surgir o indivíduo "plugado a máquina", ao mesmo tempo em que se aliena, se conforma, se acomoda, se indigna ao lidar com a velocidade de tempo e espaço e em crise, percebe o rompimento com o SEU tempo. Sempre é tempo presente na troca com a máquina. O momento é já, a velocidade está nas respostas, no compartilhamento com os demais, mas ao mesmo tempo no individualismo do ser "plugado à máquina". O mundo fictício é mais forte, uma simulação digital representa na tela do computador o olhar de um filho, uma propaganda de aparelho dentário, uma praia deserta, um gráfico de resultados. Esse indivíduo "plugado" 
habita proporcionalmente dentro de cada homem e sua crise não está mais na dominação imposta pela fábrica. A crise está na condição de estar presente e ao mesmo tempo ausente, de pertencer ao grupo e não se pertencer. Qual a emoção de se emancipar com o desenvolvimento de novos conhecimentos? A emoção talvez esteja em adiar o prazer de beijar o filho, de mudar os dentes, de sair em viagem - o prazer não vivido, por falta de tempo, por não ter estado com o outro e pela dificuldade do estar juntos. Um tempo linear, com começo, meio e fim, não nos pertence mais. Um novo tempo cultural trouxe a necessidade de uma nova maneira de compreender o homem, que sofre do mal estar na civilização. Em uma obra exatamente com esse título, Freud (1997) argumenta:

Durante as duas últimas gerações, a humanidade efetuou um progresso extraordinário nas ciências naturais e em sua aplicação técnica, estabelecendo seu controle sobre a natureza de uma maneira jamais imaginada. As etapas isoladas desse progresso são do conhecimento comum, sendo desnecessário enumerá-las. Os homens se orgulham de suas realizações e têm todo direito de se orgulharem. Contudo parecem ter observado que o poder recentemente adquirido sobre tempo e espaço, a subjugação das forças da natureza, consecução de um anseio que remonta a milhares de anos, não aumentou a quantidade de satisfação prazerosa que poderiam esperar da vida e não os tornou mais felizes. (FREUD 1997:39).

A visão de Freud leva a um questionamento que pode trazer mais alguns elementos para a necessidade de se construir uma nova maneira de compreender a realidade: a questão fatídica para a espécie humana está em se saber até que ponto seu desenvolvimento cultural conseguirá dominar a perturbação de sua vida comunal causada pelo instinto humano de agressão e autodestruição. Entende-se que mudança sempre aconteceu, mas nos dias atuais a conjuntura está acima de tudo e há um importante movimento na organização do meio e do processo comunicacional, como o orientador dos rumos da sociedade de hoje.

O saber formal está nas escolas e nos escritos, mas o saber também está nas mídias e no uso da tecnologia como meio de comunicação. Saber faz sentido se for para aplicar hoje, para fazer um mundo melhor. A comunicação mediada pela tecnologia permite ao homem e à sociedade articular novas práticas culturais. O foco dos estudos em comunicação não está mais no emissor, mas no estudo da diversidade de olhares, necessidades e desejos. O diverso surge como constituinte para a comunicação, de modo que se convive com a negociação do conflito, com o espaço público, com o imediato e com a compreensão de que não há pensamento único; vivemos o plural e o diverso. Tudo depende do conhecimento que acessarmos e do uso que fizermos dele. 


\section{A Justificativa}

O livro "O Lado Humano da Empresa", de Douglas McGregor, é considerado um clássico na História da Administração, apresentando em 1960 uma tese inovadora em motivação, quando definiu que o papel do gestor na administração da empresa é organizar recursos, inclusive pessoas, para que a empresa atinja seus objetivos. Para tanto, apresentou duas teorias opostas: a $\mathrm{X}$ e a $\mathrm{Y}$, que podem esclarecer sobre a forma como os gestores percebem a motivação dos funcionários e estabelecem um estilo gestão.

A Teoria $\mathrm{X}$ considera que o trabalho é desagradável e a maioria dos trabalhadores procura evitá-lo; a capacidade criativa e a iniciativa são características incomuns; as pessoas não desejam ter responsabilidades e precisam ser controladas. Nesse caso os gestores exercerão supervisão cerrada, controle rígido e ações coercitivas.

A Teoria Y é mais avançada e considera que se as condições forem favoráveis, o trabalho pode ser algo natural e prazeroso e as pessoas podem atingir os objetivos organizacionais de forma criativa e comprometida. Nesse caso os gestores vão procurar alinhar os objetivos da organização e os objetivos individuais, manterão estruturas mais descentralizadas, poderão delegar mais poder de decisão aos níveis operacionais e promover a participação, favorecendo maior amplitude às funções. Portanto, nessa teoria, a organização deve colher como frutos: maior produtividade, mais inovação e capacidade de proporcionar a satisfação no trabalho.

Considerando-se que o livro foi publicado originalmente em 1960, supostamente, a Teoria Y deveria ter acompanhado a evolução dos profissionais e a demanda por melhores condições de trabalho e deveria também servir de bússola para a ação da maioria dos gestores.

Contraditoriamente, a evolução dos mercados, a velocidade da informação, a flexibilidade necessária, a inovação e a mudança no nível de emprego marcaram o fortalecimento da Teoria X em muitos segmentos econômicos, apesar do discurso dos administradores pouco falarem a respeito de algo tão desagradável.

Thomas Wood Jr. ${ }^{2}$ no seu artigo "A Volta da Teoria X", esclareceu que essa predominância tem algumas explicações e afirma que:

\footnotetext{
${ }^{2}$ Fonte: Wood Jr, Thomas. A volta da teoria X . Revista Carta Capital. Edição 06/04/2005, n³36 ano XI e pág 37
} 
A razão presente em países subdesenvolvidos como Pindorama, é que parte considerável da população ainda não teve as condições mínimas de subsistência atendidas. Além disso, a falta de maturidade profissional e a capacitação profissional insuficiente de gestores e funcionários mantêm práticas anacrônicas em pleno uso. (WOOD JR, 2005: 37)

$\mathrm{Na}$ visão do autor a razão relaciona-se a alguns traços culturais ainda fortes nas empresas: alta "distância de poder" entre líderes e liderados e a "postura de dependência". Considera-se então que esses traços dependentes nas empresas tendem a validar os pressupostos da Teoria $\mathrm{X}$ e não aqueles da Teoria Y. Wood Jr (2005) finaliza o artigo com uma colocação de extrema lucidez e alerta:

Muitas organizações locais vivem situações paradoxais: a convivência do discurso Y com práticas $\mathrm{X}$. Seus gestores e funcionários parecem agir como se sofressem de esquizofrenia, a substituir a realidade por visões idealizadas da empresa e de si mesmo. Se escapassem da retórica empolada e depositassem os pés no chão talvez pudessem atuar de forma mais consistente e superar o atraso. (WOOD JR, 2005: 37)

Para explorar novas idéias e estar desejoso de rever modelos emprestados durante a educação formal, o gestor e funcionários devem estar interessados em afastar os velhos modelos de ação, buscando a compreensão do quanto estes modelos de dependência geram mentes preguiçosas, entorpecidas pela autoridade, modelação, controle e condicionamento. É quando emerge a compreensão de que o velho modelo de gestão de recursos e pessoas não pode se manter por si só.

Despertar para um pensamento claro, expressar suas idéias pode ser o desejo de muitos, mas de modo geral sabe-se que as pessoas não pensam abertamente. Cada um pensa e sente sobre algo ou uma idéia, sob influência de um lado pessoal, na maioria das vezes, ameaçado pela presença do medo da exposição e de que a dúvida e a crítica destruam a estrutura das crenças anteriormente construídas. O medo da dúvida é o medo da averiguação, da tensão necessária para uma nova ação. No reverso do medo encontra-se a necessidade da certeza, a mesma que pode estar criando uma barreira para se realizar uma ação ou bem próximo, uma barreira que força a necessidade do controle da situação e acaba por tornar-se um fardo para cada indivíduo.

Sob a ótica da criatividade entende-se que talvez essa perfeição do pensamento possa estar no preenchimento constante das idéias em movimento, da mesma forma que as pessoas em desenvolvimento buscam a inteligência inovadora e não apenas uma imitação de um modelo ideal emprestado de alguma teoria. Nesse sentido, o conhecimento enquanto mero acúmulo de idéias e informações impede o movimento livre do pensamento, pois o 
pensamento é tomado pelo medo da crítica que impede as pessoas de descobrirem o valor inerente a um fato, uma experiência ou uma idéia.

Muitas idéias são consideradas pelas pessoas apenas quando há uma qualidade atribuída às idéias, à possibilidade de alguém tirar proveito, lucrar ou gerar poder com elas. $\mathrm{O}$ processo de compreensão não vem da mera repetição das idéias anteriormente experimentadas.

Assim, o gestor não é instrutor ou um pregador, que traz um auxílio temporário e pontual de novas idéias e novas formas de agir, que geram conforto. Sua comunicação deve ser entendida como algo a ser amadurecido, pois as idéias novas geram dúvidas e incômodos e seria sábio compreender que vários aspectos da mesma verdade emergem da variedade e diversidade de idéias de tantas outras pessoas.

Considerando-se que a administração tem sua razão de existir como ciência para dar apoio à manutenção da idéia central da estrutura e do modo de produção capitalista, que resultará no lucro almejado, todo seu esforço visa um desempenho adequado para o sucesso organizacional da comunidade, de seus clientes, de seus acionistas, de fornecedores e esperase o mesmo de seus profissionais.

Querer questionar a idéia que se tem deste sucesso, de segurança, de resultado, de ganhar oportunidade no mercado, dentre outros temas, é ceder espaço para a inteligência procurar por novos fatos onde esses temas já estejam presentes; os novos fatos são aqueles não revelados ainda, mas também ali dentro do contexto, vigiados por múltiplos olhares, que observam de muitos postos e compreendem outras facetas de um mesmo fato ou aparente verdade.

Essa idéia de apenas produzir, crescer cumulativamente, tem se revelado cada vez mais falsa, na medida em que o mesmo homem que aumenta sua propriedade, mais nela se encerra ou, quanto mais aumenta o conhecimento, mais pode estar limitado por ele. $\mathrm{O}$ ter, não garante sucesso absoluto, pois quando as pessoas se apóiam em um processo de sobrevivência de modo superficial, elas se afastam da perspectiva de um contínuo de aprendizagem e do uso da inteligência humana.

A história da ciência desenvolvida pelo homem tem muito de separação entre pensamento e emoções, e o uso da racionalidade absoluta pode estar gerando decisões menos completas e harmoniosas. É o que revela a história da humanidade. 
Em um contexto organizacional acredita-se que um gestor movido pela visão da Teoria Y, de McGregor, precisa aprender sobre motivação para despertar as pessoas para decisões e ações mais completas e harmoniosas. Entende-se que cada um pode despertar para a forma como vem tratando e motivando as pessoas, quando analisar se as próprias ações são mais completas e harmoniosas ou estão envolvidas por crueldade, opressão e exploração.

As pessoas também devem aprender sobre motivação e como têm sido as suas ações, pois quem se submete às condições impostas não enxerga as perspectivas de mudanças.

Para gestores/pessoas avaliarem sua capacidade de saber agir é importante compreender que não basta raciocínio e discussão; quando uma ação é motivada por um sentimento intenso, o processo de comunicação entre as pessoas pode revelar uma afinação do pensamento e sentimento. Sem a harmonização da razão e da emoção, a ação pode ocorrer, mas com o ônus dos conflitos e da falta de vontade para a construção de novas realidades e novas bases para o poder de decisão.

Do apoio à individualidade, (não ao individualismo), cria-se um espaço para inteligência criadora, que é caracterizado pela ausência do medo e do aprisionamento à ilusão. Enquanto prevalecer a busca do poder, da sedução e das crenças confortáveis, não há inteligência criadora. É preciso o desconforto para se aprender sobre a inteligência. É preciso experimentar, não um modelo, mas alternativas que possam auxiliar uma pessoa a fazer uso de sua inteligência, além dos caminhos convencionais de educação e treinamento. A verdadeira educação não traz conforto, pois cria entendimento sobre as ações dos homens e do cenário construído, portanto essa verdadeira educação trará consciência e uma preocupação de melhorar "a si próprio" para poder estimular os demais.

As instituições estão estruturadas para garantir o bem estar físico do homem e não para conduzi-lo à verdade. Nesse sentido a verdade não pode ser encontrada através de uma organização, de qualquer método ou modelo institucional, mas quando o indivíduo, por seu entendimento, for capaz de criar inteligência ao seu redor, inteligência para responder às novas situações, para trazer um novo entendimento nas organizações sobre a forma de perceber a realidade e agir nesse contexto. A verdade pode ser exercitada com o princípio da convivencialidade, enquanto conceito novo que traduz a expressão da vida nas empresas. É um princípio que enfatiza a percepção como uma capacidade humana que precede a aprendizagem e o uso dos conhecimentos e que liberta a mente, antes presa à imitação e ao temor. 
Nas organizações os gestores e pessoas não revelam inteligência, porque seguem mestres, gurus, líderes, dirigentes não inteligentes... A questão é aprender a usar a mente para aprender com eles. A comunicação é um processo da mente - verbal, intelectual e conceitual.

Para haver comunhão de idéias torna-se necessário entender que comunhão é processo da "não-mente", pois implica em transferência de energia, não verbal - um salto de um coração ao outro.

Rever os padrões previamente estabelecidos para certo nível de interação convivencial, pode levar os indivíduos a buscarem uma abertura dos canais de comunicação, os quais podem permitir um compartilhamento de conhecimentos e da possibilidade de reconstrução de idéias para enfrentar o imponderável.

Em um ambiente preocupado com a convivencialidade as pessoas aprendem sobre o respeito com relação ao outro. Para Agostinho, Bauer, Predebon (2002), a convivencialidade:

(...) é a atitude de reconhecer o outro, com quem nos relacionamos, como um 'legítimo outro' - por sermos capazes de reconhecer a nós mesmos nesse outro. A convivencialidade busca transcender o utilitarismo em que o 'outro' representa apenas o uso que se faz dele. Isso se aplica às relações que mantemos conosco mesmos, com as demais pessoas, a sociedade, o mercado e a natureza. (AGOSTINHO, BAUER, PREDEBON: 2002:13).

No sentido de criar uma perspectiva para a construção de um ambiente de convivencialidade nas organizações e para a gestão COM pessoas, torna-se necessário rever, criticamente, o senso comum do que é comunicação, em termos de linguagem e como se pode apropriar dela, sem se deixar, ou querer manipular nas interações do mundo do sistema complexo. Para a comunicação, a convivencialidade pode facilitar na aprendizagem sobre o que ocorre em nossa volta e de como todos os indivíduos, em interação, contribuem cada qual com sua visão, para a construção das melhores respostas. E ainda, a convivencialidade torna o sistema complexo da interação mais fluído, facilitando mudanças de estrutura, revisão de conceitos ou de comportamentos.

Um sistema organizacional complexo muda e sobrevive enquanto a comunicação estimula a revisão de processos produtivos internos e o relacionamento com o ambiente externo e, novas aprendizagens. O processo comunicacional representa a capacidade do indivíduo ou da organização de se relacionar e se integrar aos demais membros, departamentos, clientes, fornecedores ou acionistas, permite o exercício de prestar atenção ao outro, de integrar o mundo interno de cada um com o mundo externo. Assim, sem dúvida, deve-se considerar que fontes emissoras de informações se deparam com públicos diversos e a 
comunicação intencionada pode não ter o efeito esperado, se também não houver um cuidado com aspectos relacionais e canais abertos para conhecer os condicionantes de um processo comunicativo, o qual seja reconhecidamente considerado eficaz pelas partes envolvidas.

Essa complexidade do processo comunicacional obriga a organização e seus membros a fazerem uma avaliação crítica da visão puramente mecanicista e instrumental da comunicação, para conceber um foco mais crítico e que permita explorar a abrangência de seus conceitos. Espera-se da comunicação uma sintonia com o processo de relacionamento entre indivíduos e estruturas e a própria contemporaneidade e que favoreça a "leitura" dessa realidade social, para que as pessoas possam compreender além de seus próprios interesses e saber agir com responsabilidade.

Conforme Kunsch, (2003:73), “acredita-se que as organizações, em pleno início do século XXI, não mudaram muito o seu comportamento". Muitas vezes as empresas têm uma retórica moderna, mas suas atitudes e ações comunicativas estão ainda impregnadas por uma cultura tradicional e autoritária do século XIX. Para Kunsch (2003) a abertura de canais e a prática da "comunicação assimétrica" requerem uma nova filosofia organizacional e a adoção de filosofias mais críticas, capazes de incorporar atitudes inovadoras e coerentes com os anseios da sociedade moderna.

Verifica-se, portanto, que os problemas da organização não são simplesmente resolvidos pelo fato de existir comunicação. São muitas as variáveis que influenciam na ação de um agrupamento de profissionais, são muitas as barreiras que se formam no processo de comunicação e elas dizem respeito à cultura, conhecimentos desenvolvidos, influência do ambiente externo e capacidade de aprender a enfrentar problemas de inter--relacionamentos.

(...) para compreender a complexidade do ato comunicativo, um dos caminhos é estudar alguns elementos ou aspectos relevantes presentes na gestão do processo comunicativo nas organizações: as barreiras, os níveis de análise, as redes, os fluxos, os meios $\mathrm{e}$ as diversas modalidades comunicacionais existentes. (KUNSCH 2003: 73).

Nas organizações mais fechadas e chamadas de mecanicistas ocorre maior dificuldade para se enfrentar ambientes instáveis e em ritmo de mudança. Nas organizações orgânicas, aquelas consideradas abertas ao relacionamento com o meio ambiente, revela-se uma capacidade maior de acompanhamento das transformações que ocorrem na sociedade e implementação de novas formas de gestão que permitam enfrentar as condições impostas pelo ambiente e pela história contemporânea. A comunicação pode contribuir para maior simplicidade, flexibilidade e transparência nas organizações. 
Nesse sistema aberto e flexível, o enfoque administrativo está no atendimento às necessidades dos clientes e também dos não clientes, assim como no relacionamento que enfatiza a participação, nos princípios de administração que são cada vez mais substituídos por desenvolvimento profissional, na prevalência de uma nova tônica para uma gestão tão participativa quanto integrativa e com permanente revisão e melhoria de processos de trabalho, na visão de mundo com foco nos saberes interdisciplinares que facilitam o lidar com o novo e na estrutura organizacional que é menos funcional e mais centrada no processo de produção e nas equipes de trabalhos.

Nessas organizações as competências profissionais devem ir além dos conhecimentos específicos e envolvem segundo Fleury (2002: 55), "um saber agir, mobilizar recursos, integrar saberes múltiplos e complexos, saber aprender, saber se engajar, assumir responsabilidades, ter visão estratégica. Do lado da organização, as competências devem agregar valor econômico para a organização e valor social para o indivíduo”. Organização e pessoas propiciam um processo contínuo de troca de competências e as realizações dependem do grau de competências desenvolvido no todo. O ambiente tende a ser menos competitivo e mais cooperativo, pois os relacionamentos exigem maior troca e as pessoas se desenvolvem preparando-se para enfrentar novas situações profissionais e pessoais, dentro ou fora da organização. A comunicação, como competência de apoio pode contribuir para construção de uma visão clara sobre o acesso aos horizontes profissionais, sobre autodesenvolvimento e ampliação do espaço ocupacional.

O uso do conceito de competência permitiu um interesse sobre gestão de pessoas mais alinhada às necessidades e expectativas das organizações e dos indivíduos.

Buscam-se ganhos para a organização e para as pessoas. Dutra (2001), afirma que a empresa transfere seu patrimônio intelectual para as pessoas e as pessoas, ao colocarem em prática o patrimônio de conhecimentos da organização, concretizam as competências organizacionais e fazem sua adequação ao contexto, implementando as modificações necessárias para seu aprimoramento. Com sua contribuição, uma pessoa se desenvolve como profissional e adiciona valor social ao seu perfil pessoal. Isso melhora suas expectativas de educação, de melhor condição para seu tempo de vida e perspectivas de se manter em condições equilibradas para seu sustento e de sua família.

A comunicação pode contribuir para maior simplicidade, flexibilidade e transparência nas organizações. No processo evolutivo do universo da administração dos recursos humanos, o conceito de modelo de gestão de pessoas visa o desenvolvimento das pessoas para manter as 
empresas competitivas, dando-lhes atenção porque são consideradas o capital humano da organização. O modelo de gestão COM pessoas implica um conjunto organizado de políticas, práticas e processos de gestão, que afetam profundamente a própria filosofia adotada pelo sistema de Administração de Recursos Humanos - ARH. A proposta afeta a forma de conduzir o processo de adaptação de administradores de recursos humanos e gestores aos processos de mudanças, ao desenvolvimento da compreensão sobre esse processo e sobre a necessidade de aprendizagem para esses novos tempos, como uma premissa.

A competência comunicação é uma capacidade que vai além da condição de ouvir, processar e compreender o contexto da mensagem. É uma competência de apoio para a própria avaliação, para saber lidar com fluxos de informações no âmbito da interação entre partes diversas, argumentando COM o outro e usando o feedback para melhorar a interação de administradores e gestores com os demais membros envolvidos com a organização.

Quando se fala sobre organização pensa-se em um estado de relações ordenadas, metas, ambiente controlado e em uma força de trabalho dedicada a uma operação eficiente. Esse modo de pensar mecanicista definiu um conjunto de relações mecânicas, pois o uso das máquinas na indústria exigiu que as organizações e as pessoas se adaptassem a elas. Ao procurar aumentar a eficiência, os dirigentes das fábricas diminuíram a liberdade de ação dos operários e o disciplinamento foi introduzido para que os operários aceitassem as rotinas duras de produção industrial.

Embora Taylor seja freqüentemente visto como vilão que criou a
administração científica, é importante entender que ele, na realidade, era
parte de uma tendência social mais ampla, que envolve a mecanização da
vida em geral [...] Em geral, o taylorismo foi imposto nos locais de trabalho.
Muitos de nós impomos formas de taylorismo dentro de nós mesmos, à
medida que treinamos e desenvolvemos capacidades especializadas de
pensamento e ação, que modelamos nosso corpo para atender a certos ideais
preconcebidos. Sob a influência do mesmo tipo de mecanicismo, que ajudou
a Taylor se tornar tão poderoso, muitas vezes, vemos e tratamos a nós
mesmos como se fôssemos máquinas. (MORGAN 2000: 48).

Esse caráter de mecanicismo também direciona a comunicação e as relações humanas no ambiente de trabalho para o modelo de gestão institucionalizada, com práticas e processos que indicam o que é desejado para o sucesso da empresa.

O modelo de gestão de pessoas vai além de questões da produção e do trabalho mecânico e não se reduz ao caráter instrumental, mas envolve uma dimensão que compreende condições de trabalho, condições de convivencialidade, a organização do trabalho, as relações hierárquicas, o tipo de estrutura organizacional, os sistemas de avaliação e controle de 
resultados e, principalmente, como ARH desenvolve políticas em termos de gestão de pessoas e objetivos, como enfatizam a comunicação com o público interno para avaliar o seu próprio trabalho, os valores e a filosofia de gestão adotados pela área e expandidos para demais gestores. Define-se aqui um novo objetivo para ARH com visão na gestão COM pessoas, o de criar uma visão, por meio do processo de comunicação, da existência clara de uma correlação coerente entre o que a empresa prescreve, a partir de seu instrumental e políticas de Recursos Humanos, com aquilo que é praticado ou desejado pelos grupos e pessoas.

A criação dessa visão deve refletir a dinâmica real de comportamento organizacional desejada e as condições necessárias para os gestores reinventarem o aparato formal e se comprometerem com as pessoas.

\section{O Problema de Pesquisa}

Como a comunicação, ao ser utilizada como competência de apoio para introduzir novos conceitos na Gestão COM pessoas, pode contribuir para alterar o comportamento de gestores habituados à forma tradicional de administração de recursos humanos e de busca de resultados econômicos, para uma inclusão da busca de Resultados Humanos - RH?

\section{A hipótese}

No contexto das transformações e novas competências requeridas é necessário "rearranjar" nossos pensamentos sobre aquilo que supúnhamos arranjados.

No gerenciamento administrativo a comunicação tem sido utilizada como uma ferramenta para moldar comportamentos e para que a empresa alcance resultados econômicos, mas a empresa não se refere a resultados humanos.

A moldagem destrói a maior parte da personalidade das pessoas, seus sonhos e suas ambições, o que contraria as necessidades de um novo contexto de conhecimento e aprendizagem, no qual as pessoas são valorizadas por competências que agreguem valor aos produtos e serviços.

Para atender às estratégias do negócio, a administração de recursos humanos é responsável por fornecer as diretrizes para a gestão de pessoas; um novo modelo de comportamento deve ser estimulado pelos gestores, mas desta vez com seus pensamentos já "re-arranjados". Gestores devem ter aprendido que os comportamentos não são gerados ou produzidos pela organização, mas são resultados da forma de gerir COM pessoas, dando 
atenção à comunicação, suporte ao desenvolvimento, aprendizagem de dupla mão e efetividade na valorização profissional pelo potencial desenvolvido.

A contribuição da comunicação como uma competência de apoio para administração de recursos humanos, revela a perspectiva de construção de uma linguagem básica, cuja maior instrumentalidade está em comunicar PARA que as idéias do novo contexto sejam entendidas. Amplia-se assim o foco de administração de recursos humanos, que sinaliza para os gestores sobre a importância da introdução e manutenção de conceitos como o de convivencialidade e inteligência social, como um primeiro passo para uma busca de resultados humanos, cujos indicadores podem ser verificados quanto ao nível de educação, condições para a longevidade e a sustentabilidade financeira, detectados junto aos funcionários.

\section{Objetivo Geral}

O objetivo geral deste trabalho é apresentar alguns conceitos e esquemas práticos para desencadear processos consistentes de mudanças na gestão COM pessoas, a partir de uma visão inovadora da comunicação como competência de apoio para o grande desafio de administração de recursos humanos - gerar resultados humanos.

\section{Objetivos Específicos}

- Construir um cenário das organizações no mundo contemporâneo relacionado à evolução da administração de recursos humanos;

- Trazer elementos para uma visão crítica do papel da comunicação na gestão de pessoas, considerando os aspectos instrumental e relacional;

- Apresentar as competências sob a ótica do saber Pensar, Sentir e Agir e introduzir os conceitos de convivencialidade e inteligência social para favorecer o desenvolvimento de competências;

- Promover a visão da comunicação como competência de apoio para administração de recursos humanos e da Gestão COM Pessoas.

Para tanto, torna-se necessário entender que houve uma evolução na forma de encarar o que é uma competência nesse trabalho. Na administração clássica as competências eram compreendidas como habilidades e atitudes desenvolvidas pelas pessoas para exercício de uma função. Numa nova noção, o conceito de competência, conforme Dutra (2001), envolve 
uma idéia de entrega. $\mathrm{Na}$ sua visão as pessoas possuem um conjunto de conhecimentos, habilidades e atitudes que nem sempre garantem que a empresa se beneficie diretamente dele e ao incorporar a noção de "entrega", o autor esclarece sobre a idéia do que realmente uma pessoa entrega na organização. O termo "entrega" se refere à ação do indivíduo que sabe agir de forma responsável, sendo reconhecido por isso. O esforço que as pessoas despendem na execução de seu trabalho depende de seu desenvolvimento pessoal e profissional e da qualidade que elas adicionam ao seu trabalho. São muitas as dificuldades encontradas pelas empresas para colocar em prática as novas aprendizagens requeridas para adaptação às transformações. A questão é saber definir ou combinar as diversas competências que uma empresa pode conseguir para desenhar, produzir e distribuir produtos ou serviços aos clientes. Essa capacidade de transformar recursos e ativos em lucro se traduz por competência.

\section{A Relevância do Estudo}

Quando uma empresa consegue criar um ambiente de trabalho que valorize o capital humano, em que as pessoas encontram espaço para "entregar" suas competências e prosperar, numa relação de troca, elas também intensificam seu compromisso com desempenho, novas aprendizagens e resultados a serem atingidos. Portanto, criar essa condição tem sido um desafio para as empresas e para os profissionais da administração de recursos humanos, mas falta elaborar as causas que dificultam essas transformações.

Há pouco investimento em comunicação para tratar de questões referentes aos resultados gerados pelos profissionais e resultados no desenvolvimento humano, ou sobre a postura de gestores, ou sobre como conviver com frustrações e desencantos.

A comunicação para promover a convivencialidade e a construção de caminhos para o desenvolvimento é uma inovação aplicada à Administração. De modo geral a comunicação organizacional tem se revelado muito mais instrumental do que relacional. Quaisquer que sejam as práticas adotadas pela administração de recursos humanos, elas devem traduzir uma orientação para pessoas e não para recursos. Os recursos agregam valor ao negócio e os humanos se desenvolvem, (ou pelo menos deveriam se desenvolver).

É importante compreender como os conceitos herdados da administração científica evoluíram e como o contexto atual de vida e de crescimento mudaram de rumo, pois não se trata apenas de produzir bens. A empresa e a reprodução do capital se vêem diante de questões como planetarização, globalização da economia, tecnologia e sustentabilidade. 
Mudaram as condições e os papéis dos envolvidos e tudo isso deve ser comunicado e discutido com as pessoas. As empresas não estão isentas desse processo de transformação, elas estão inseridas no contexto globalizado, que revela altos níveis de avanços tecnológicos com baixos níveis de desenvolvimento humano. Trata-se de um alerta para a necessidade de uma reforma no modo de pensar.

O modelo de competências é uma ideologia que pode contribuir para o desenvolvimento humano, na medida em que há um estímulo para o desenvolvimento do potencial do Ser Humano, envolvendo as suas capacidades de pensar, sentir e agir: "Pensar" baseado em conhecimentos; "Sentir" que lhe permita entrar em contato com sua subjetividade, com o conhecimento de si próprio e do outro, seus limites e seus talentos e os talentos dos outros, sobre aprender e compartilhar, sobre inovar, rever conceitos e abrir espaços mentais para uma nova leitura da realidade; "Agir" menos reativo, com capacidade de construir alternativas e fazer opções. O agir implica estar consciente de sua responsabilidade pela busca de novas competências. Mudou o perfil do cidadão requerido pela sociedade, mudou o perfil dos profissionais requeridos pelas empresas; a obediência é substituída por responsabilidade que se revela na capacidade de tomar decisões e de dar respostas aos desafios da complexidade de um novo tempo.

Por necessidade de novas exigências de mercado e competitividade, ou por absoluta opção, algumas empresas já mudaram o foco do tratamento dado às pessoas, de controle para desenvolvimento profissional e parece que o humano está embutido, mas isso não está claro. Muitas vezes a pessoa é vista como a gestora de sua relação com a empresa e responsável por seu desenvolvimento. É importante verificar que a participação das pessoas no sucesso da organização é muito maior.

O comprometimento dos indivíduos com a organização ou negócio, mobiliza, não somente músculos e parte da inteligência, mas todo seu potencial criador, sua intuição, sua capacidade de interpretar o contexto e agir sobre ele, gerando vantagens competitivas únicas. As pessoas são depositárias do patrimônio intelectual da empresa, bem como da capacidade e da agilidade de resposta da organização aos estímulos do ambiente e, ainda, da capacidade de visualização e exploração das oportunidades de negócio. (DUTRA 2001:26).

$\mathrm{Na}$ visão de Chanlat (1993) a capacidade das pessoas em se relacionarem é mais importante do que a competência técnica ou a habilidade de se comunicarem. Acredita-se que com a convivência as pessoas podem compartilhar experiências e conhecimentos, explorar novas visões e poder exercitar a sua própria vontade. São idéias muito simples e a comunicação para compreensão de idéias pode levar à essência das dificuldades para 
mudanças e desenvolvimento humano: acreditar na possibilidade de equilibrar de forma consciente o pensar, o sentir e o agir.

Nas empresas essa missão pode ser realizável por gestores e seus grupos a partir de um pensamento comunicacional que aborde esses aspectos de forma construtiva e integradora:

\section{As Peculiaridades do Estudo}

Esta defesa de tese está alicerçada na argumentação de que Gestão COM Pessoas teve início desde a Experiência de Hawthorne. Os experimentos do Professor Elton Mayo incluíram uma série de estudos sobre a produtividade dos trabalhadores, inseridos em várias condições de manipulação: pagamentos, folgas, descanso, refeições, etc. Surpreendentemente a cada alteração, naquela condição vigente, o resultado era aumento da produtividade, incluindo também o retorno a alguma condição anterior, se assim fosse solicitado pelos trabalhadores. Isso acontecia com os trabalhadores individualmente e como grupo.

Parecia óbvio que as variáveis consideradas pelos estudiosos não eram as únicas causas dessa melhoria. Uma interpretação feita principalmente por Mayo e seus parceiros F.J. Roethlisberger e William J. Dickson, considerada essencial para a questão atual de gestão COM pessoas, refere-se ao fato de que os sentimentos dos trabalhadores foram sendo tratados conforme se verificava que aquelas seriam as causas que levariam às melhorias de desempenho. O fato de haver um canal de comunicação aberto para mesclar as colocações feitas por pesquisadores e pesquisados foi fundamental para a gestão das pessoas. O que provocou o aumento da produtividade foi o grupo ter sido alvo de atenção dos pesquisadores e o respeito ao ser humano.

Hoje referenciado nas escolas de administração como Efeito Hawthorne, significa que este experimento trouxe um dos primeiros indicadores de que qualquer modelo de produtividade deve trabalhar também com fatores intangíveis, mas também pela perspectiva humanística. O Efeito Hawthorne foi assim denominado porque há uma possibilidade de que os indivíduos destacados pelos experimentos simplesmente tenham melhorado seus desempenhos mais pela atenção recebida dos pesquisadores do que por causa de alguns fatores específicos que foram observados. O Efeito Hawthorne indicou que a produção melhora quando os trabalhadores acreditam que os gestores se preocupam com o seu bemestar. 
Como conseqüência dessa visão, entende-se que nenhuma motivação será suficientemente convincente, mesmo a pretexto de aumentar a produtividade, se nela estiver embutida a conotação de "utilitarismo" e "descartabilidade" aplicados às pessoas.

Outra visão diz respeito ao desenvolvimento das pessoas, à importância de estimular o desenvolvimento de talentos e habilidades e não apenas por técnicas de redesenho do cargo ou da ocupação e do enriquecimento do cargo, mas com a perspectiva de contribuição e, principalmente, com a cultura de aprendizagem organizacional e de remuneração por competência apresentada.

Acredita-se que é necessário refletir sobre a aprendizagem não apenas como sessões de treinamento, mas como resultado do convívio entre as pessoas, como ampliação da visão de necessidades do "outro" e como melhor compreensão do conceito de autodesenvolvimento a caminho do desenvolvimento profissional. Não se trata de amenizarem impactos ou dificuldades porque podemos estar adiando causas cujo efeito se traduz por cegueira e ignorância cada vez mais crônicas.

Sobre a Experiência de Hawthorne, consideram-se três contribuições como fundamentais para a gestão com pessoas:

a) Necessidade da administração de recursos humanos das empresas, bem como seus gestores, saber identificar claramente o que interessa e o que preocupa os trabalhadores;

b) Resolver problemas com questões organizacionais de uma forma sustentável, quando é feito com esquemas adequados e com a efetiva contribuição das pessoas;

c) O processo de avaliação dos profissionais não é algo estático, mas ocorre ao longo das situações enfrentadas no trabalho. Quando as pendências dos gestores são resolvidas com a contribuição dos demais membros do grupo, elas serão significativas para uma avaliação dos profissionais na medida em que gerarem resultados de longo prazo.

Diante dessas contribuições é desafio para a administração de recursos humanos:

a) Identificar as causas das questões críticas no envolvimento com o trabalho, pois algumas são intrínsecas à dinâmica da organização e de seus dirigentes;

b) Estimular o discernimento dos gestores quanto aos parâmetros para avaliação das pessoas; 
c) Como as competências críticas para o trabalho são dinâmicas, os processos e modelos adotados devem ser constantemente revistos e atualizados, conforme o quadro emergente;

d) No todo, são os gestores que promovem a convivencialidade e conduzem as questões de produtividade, então depende da percepção e discernimento deles para que as pessoas certas estejam nos lugares certos, com o real aproveitamento do perfil do profissional, do seu conjunto de conhecimentos e das perspectivas reveladas para seu desenvolvimento.

Nesse sentido a comunicação como competência de apoio para as ações de recursos humanos e a capacitação de gestores, pode contribuir para revelar novos atributos ao trabalho e garantir que nenhum conhecimento informal tácito ou explícito esteja sendo mantido escondido para alguma utilização de negação do modelo de gestão com pessoas.

Deve-se aprender que para promover um modelo de Gestão de Pessoas confiável é importante que esse modelo esteja calcado numa comunicação transparente, que permita gerar elementos para uma revisão das competências da administração de recursos humanos e dos próprios gestores, pois esse caminho estará favorecendo a formação de "espelhos", um referencial para os demais funcionários.

[...] 'o espelho' diferentemente do 'gerente' ou do 'talento' terá o papel de servir de paradigma cultural aos demais membros da empresa; é o referencial necessário para refletir as diretrizes de comportamento alinhadas com os valores fundamentais da organização e que todos empregados buscam na maioria das vezes sem encontrá-lo, a fim de balizar as suas atitudes e comportamentos dentro da organização". (MARRAS 2000: 265).

\section{Sobre a Metodologia}

\section{Natureza da Pesquisa}

Uma pesquisa é válida quando suas conclusões são corretas e é fidedigna quando seus resultados são replicáveis.

A pesquisa em questão tem o objetivo de ser fidedigna, pois as conclusões apresentadas ao fim do trabalho não têm a pretensão de ser verdade absoluta, mas sim um ponto de partida para futuros estudos.

No campo das ciências sociais, a realização de pesquisas tem sido fortemente influenciada por métodos quantitativos nas descrições e explicações de interesse. Nos dias 
atuais, contudo, verifica-se uma abordagem diferente, que gradualmente se estabelece como uma alternativa de investigação que permite gerar condições mais abrangentes e holísticas em contextos organizacionais e sociais.

Trata-se da pesquisa qualitativa (GODOY, 1995). Este tipo de pesquisa apresenta as seguintes características, segundo Bogdan (apud GODOY, 1995):

1) A pesquisa qualitativa tem o ambiente natural como fonte direta de dados e o pesquisador como instrumento fundamental;

2) A pesquisa qualitativa é descritiva;

3) O significado que pessoas dão às coisas e à sua vida é a preocupação essencial do investigador;

4) Pesquisadores utilizam o enfoque indutivo na análise de seus dados e

5) Os pesquisadores qualitativos estão preocupados com o processo e não simplesmente com os resultados e o produto.

Desta forma, pelo paralelismo com os objetivos do trabalho, o tipo de pesquisa utilizado será a pesquisa qualitativa.

\section{Caracterização da Pesquisa}

A presente pesquisa, levando-se em conta o objetivo principal do trabalho, se caracteriza como exploratória e avaliativa, conceitos introduzidos por Selltiz (1987). Exploratória no momento em que se pretende encontrar os elementos necessários que permitam um contato com determinada temática para obter os resultados desejados e avaliativa, no momento em que o pesquisador se propõe a estabelecer alguns paralelos que permitam identificar fatores que indiquem que gestão, comunicação e pessoas, intermediadas pelo conceito de convivencialidade apresentam um esquema eficiente e não somente mais um modismo.

É importante observar, para efeito dessa pesquisa, a existência de grandes debates contemporâneos sobre as ciências sociais e apresentar em destaque a consideração de Apolinário (2006: 42), “...parece razoável supor que nos encontramos em um momento de crise paradigmática da ciência. Essa crise cujo pivô temático surgiu já ao final do século XIX, com as querelas metodológicas entre as concepções objetivistas-racionalistas e subjetivistas- 
relativistas, fruto dos desenvolvimentos desarmônicos entre as ciências da natureza e as ciências sociais, não aparenta ter solução no horizonte próximo. E, ao que parece, o surgimento de novos paradigmas nunca ocorre de forma tranqüila e consensual".

\section{Tipo e Modo de Investigação}

O processo de leitura exploratória, seletiva, reflexiva e interpretativa é denominado por Ruiz (1979) como pesquisa bibliográfica. Qualquer espécie de pesquisa, independente da área, supõe e exige pesquisa bibliográfica prévia, quer como atividade exploratória, quer para estabelecer o status quaestions, ou ainda para justificar os objetivos e contribuições da própria pesquisa.

De acordo com Minayo (1993:97), a pesquisa bibliográfica "é capaz de projetar luz e permitir uma ordenação ainda imprecisa da realidade empírica”.

\section{A abertura Disciplinar}

A década de 1960 inaugura o início dos estudos sobre interdisciplinaridade. Surge entre teólogos e fenomenólogos a busca de um sentido mais humano para os estudos, que se baseiam numa antropologia filosófica. Torna-se necessário que profissionais de diversas áreas se deparem com o tema.

Para esse trabalho buscar uma ordenação de elementos que traduza a realidade organizacional, princípios de administração, gestão de pessoas e sua subjetividade, requer-se um enfoque interdisciplinar e, na visão de Fazenda (1991), "não existe a possibilidade de estabelecer uma teoria geral e absoluta da interdisciplinaridade, pois o caminha teórico traçado por cada pesquisador define as questões da interdisciplinaridade".

Interdisciplinaridade é mais do que o sintoma de emancipações de uma nova tendência em nossa civilização. É o signo das preferências pela decisão informada, apoiada em visões tecnicamente fundadas, no desejo de decidir a partir de novos cenários construídos sobre conhecimentos precisos. (FAZENDA 2003: 75).

Nenhum ramo do conhecimento pode cobrir todos os aspectos da existência humana.

(...) é por essa razão que existem várias disciplinas. Mas, freqüentemente, o espírito disciplinário oculta outros aspectos da realidade, arrastando por essa via os vícios intelectuais bem conhecidos que são o reducionismo e o 
imperialismo que reduzem todo esforço de compreensão verdadeira [...] Baseado nas observações da historiadora das ciências quebenquence, Camille Limonges (1996), mas também em Stengers (1987), o que nós reclamamos não é a erradicação de disciplinas, com objetos próprios e métodos diferenciados, mas o reconhecimento do direito e mesmo do dever de circular, a valorização do livre trânsito, o levantamento de barreiras à associação com pessoas diferentes, sociólogos, economistas, psicólogos, biologistas, filósofos, administradores e tantas outras disciplinas que consideram o homem como ser vivo consciente e sociável, resumindo: a liberdade de estabelecer redes segundo sua vontade e interesse de complementaridade. (CHANLAT 2000: 64).

Entende-se que se todas as disciplinas são convocadas, cada uma deve estar bem consciente de que desvenda apenas uma parte da realidade estudada. Nos últimos anos, segundo Chanlat (2000):

(...) as ciências da linguagem contribuem igualmente para esclarecer a questão do sentido, porque não existe construção do sentido sem linguagem. É pela linguagem e graças a ela que a humanidade pode desenvolver pensamentos, sistemas de significações e relações sociais. Toda existência repousa, de fato, sobre comunicações que supõem uma forma de linguagem. $\mathrm{O}$ mundo da gestão é um universo que não escapa à lei dessa vida em sociedade. (CHANLAT 2000: 67). 


\section{1- FUNDAMENTAÇÃO TEÓRICA}

\section{1- A Herança da Administração Gerencial}

A partir dos anos 1980 um verdadeiro culto à empresa trouxe à tona um "espírito gestionário" e as pessoas em administração estão aprendendo sobre gestão. Essa é a sociedade do gerenciamento e do seu interior surge o gestor.

Do ponto de vista organizacional pode-se perceber como noções e princípios administrativos se estendem da empresa privada tais como: eficácia, produtividade, performance, competência, empreendedorismo, qualidade total, cliente, produto, marketing, desempenho, excelência, reengenharia etc., também passaram a fazer parte de escolas, universidades, hospitais, museus, teatros, Organizações não Governamentais - ONG's ou administração pública.

Essa invasão do "gerenciamento" pode ser observada na vida privada e procura--se aprender sobre gerenciamento das emoções, do tempo, da imagem, pois o gerenciamento faz parte da capacidade do indivíduo de explicar o mundo a partir das categorias da gestão.

Para Chanlat (2000:16), "De fato, durante muitos anos, considerada um lugar de exploração, de dominação e de alienação pela maioria, a empresa tornou-se a instituição por excelência, fonte de riquezas e de cultura destinada a resolver a maioria dos problemas com que nos defrontamos hoje".

É neste contexto de sociedade, em que se busca racionalizar todas as esferas da vida social, que as ciências humanas e a gestão começam uma relação de questionamento. Pode-se perceber sua presença no processo de racionalização do mundo analisado por Weber (1982:66):

(...) capitalismo moderno não é "irracional"; suas instituições the parecem, na verdade, como a materialização mesma da racionalidade. Como um tipo de burocracia a grande empresa, só encontra rival na burocracia estatal, na promoção da eficiência racional, continuidade de operação, rapidez, precisão e cálculo de resultados. Tudo isso se desenrola dentro de instituições administrativas racionalmente desenvolvidas e nas quais funções combinadas e especializadas ocupam o centro de atenção. Toda estrutura é dinâmica e a anomia obriga o homem moderno a tornar-se um perito especializado, um 'profissional' preparado para uma carreira especial dentro dos canais pré-estabelecidos. O homem está, assim, preparado para sua absorção pelo barulhento processo na máquina burocrática. (WEBER 1982:66).

A maior parte das ciências humanas ou sociais surgiu no final do século XVIII. Elas são o produto de uma sociedade ocidental que introduziu a mudança permanente e apoiada em uma perspectiva que rompeu com a religião e com a literatura. Assim as ciências humanas 
surgem como fruto de sociedades em profundas mutações que procuram compreender a si mesmas, para explicar melhor o que se passava.

A Experiência de Hawthorne desenvolvida por Elton Mayo, na primeira metade do século XX, trouxe uma visão prática e útil para administração, uma forma de engenharia social cuja finalidade foi aumentar a previsão e controle dos comportamentos humanos. As contribuições de Mayo vieram ao encontro de um movimento americano de relações humanas nas indústrias.

O desenrolar dos acontecimentos do início da Revolução Industrial, em meados do século XIX colocou a seres humanos incluídos no processo de produção apenas como mais um recurso produtivo, ao lado das matérias-primas e das máquinas. $\mathrm{O}$ homem era tido como uma máquina humana que operava outra máquina mecânica. Com o desenvolvimento industrial em grande escala tornou-se menor a possibilidade de contato pessoal direto entre trabalhador e empregador. A ênfase naquele momento era colocada na produção e o trabalhador aprendeu sobre ser obrigado a trabalhar por longas horas, sob condições desfavoráveis e de padrões de supervisão rígidos, que impossibilitava o contato informal com os colegas. O contato humano era para fora do ambiente de trabalho e limitado pelas longas horas de atividades na fábrica.

Davis e Newstrom (2002) apresentam algumas personagens marcantes nesse ambiente industrial inicial. O primeiro foi Robert Qwen, um jovem gaulês dono de fábrica, por volta dos anos 1800, um dos primeiros a enfatizar as necessidades humanas dos empregados. Ele recusou-se a admitir crianças. Ele ensinou a seus trabalhadores de limpeza a moderação, melhorando também as condições de trabalho deles. Isso poderia ser chamado de moderno comportamento organizacional, mas era apenas um começo. Ele foi chamado o "pai real" da administração de pessoal pelos primeiros escritores.

Outra personagem apontada por Davis e Newstrom (2002) foi Andrew Ure, que incorporou os fatores humanos no seu "Philosophy of Manufactures" (A Filosofia das Fábricas), publicado em 1835. Ele não só configurou as partes mecânicas e comerciais da fabricação como também adicionou um terceiro fator que era o fator humano. Ele deu aos trabalhadores chá quente, tratamento médico, um "sistema de ventiladores" e remuneração pela doença contraída no trabalho. As idéias de Qwen e Ure foram aceitas vagarosamente, ou não, em seu todo e elas freqüentemente se deterioram em paternalismo de fazer o bem, mais do que numa lição de reconhecimento genuíno das pessoas e maior satisfação no trabalho. Davis e Newstrom (2002) mostram em sua obra um quadro de evolução administrativa que 
ficou mais evidente a partir do momento que a indústria expandiu o suprimento de bens e conhecimentos. Uma semente sobre as condições humanas no trabalho veio com os salários mais elevados, menos horas de trabalho e mais satisfação no trabalho.

Muitos esforços podem ter sido feitos no sentido de dar maior relevância ao fator humano no trabalho, mas os rápidos progressos nas ciências físicas desviaram a preocupação com problemas humanos para outros mais materiais. No início de século passado, Frederic W. Taylor nos Estados Unidos, despertou o interesse sobre as pessoas no trabalho, como um fator importante na indústria. Taylor por vezes chamado o "pai da administração científica" é considerado o pioneiro da organização racional do trabalho. Possivelmente com as modificações que trouxe para a administração estavam sendo preparados os caminhos para o desenvolvimento de estudos para investigar sobre o comportamento organizacional.

Sua contribuição ao campo das relações humanas no trabalho é relevante, por ter sido o primeiro a chamar a atenção para seres humanos no trabalho como fator importante para eficiência na produção. Portanto o fator humano estava diretamente associado à produtividade, no sentido de racionalização e eficiência do processo produtivo. Mesmo assim suas inovações administrativas abriram caminhos para o campo de relações humanas no trabalho.

Em seguido a Taylor, Lílian Gilbreth apresentou seu trabalho "The Psychology of Management" (Psicologia da Administração) que enfatizava o lado humano no trabalho. Durante o mesmo período Whiting Willian estudava os trabalhadores enquanto trabalhava com eles e em 1920 publicou uma significativa interpretação de sua experiência sob o título "What's on the Worker's Mind" (O que está na cabeça dos trabalhadores).

O universo de gestão na indústria é dominado pelos engenheiros que escreveram manuais de economia para manufatura. As considerações técnicas mostram efeitos e vantagens que vêm da utilização dos instrumentos e máquinas, cujo objetivo é substituir a energia do braço do homem. A explicação desse universo da indústria é essencialmente mecanicista. O gerenciamento como realidade social é conseqüência da expansão e do crescimento do tamanho das empresas no setor industrial. Criam-se as atividades ou operações de uma empresa e a figura do dirigente e do executivo com um conjunto de funções codificado por Henry Fayol.

De acordo com Silva (2001:148), para Fayol essas atividades poderiam ser divididas em seis grupos: técnicas, comerciais, financeiras, segurança, contábeis e administrativas. Essa 
última é considerada a mais importante em relação às outras. Fayol definiu a administração como a realização das atividades e que são suas funções a previsão, organização, comando, coordenação e controle.

Apesar de muitas décadas terem passado desde o estabelecimento destas funções, elas ainda são descritas da mesma forma e a função de previsão continua sendo a principal função administrativa. A base do processo era o desenvolvimento de um plano formal de ação, que ele descrevia como: "uma espécie de quadro de eventos próximos que são definidos com alguma distinção, enquanto eventos distantes aparecem, progressivamente, menos diferenciados, e isto vincula o trabalho corrente, como previsto e estipulado, em um definido período de tempo". Nesse sentido, as empresas se apóiam no crescimento da racionalização do mundo ocidental e na administração como uma expressão das crenças básicas dessa sociedade. A sociedade expressa a possibilidade de controlar a subsistência do homem através da organização dos recursos produtivos e a idéia de que a economia pode se converter numa força propulsora do melhoramento do ser humano e da justiça social. Traduz-se por uma crença de que o material pode ser usado para o aperfeiçoamento do espírito humano. Drucker (1981:4), como um dos pioneiros de gestão de empresas e defensor da emergência do gerenciamento como um acontecimento central da história social, escreveu que:

(...) a administração por ser o órgão da sociedade especificamente incumbido de tornar os recursos produtivos - isto é, responsável pelo progresso econômico organizado-reflete o espírito predominante da era moderna. Ela é na realidade indispensável, o que explica o fato de, uma vez instituída, ter crescido tão rapidamente e com tão pouca oposição. (DRUCKER 1981: 4).

\subsection{1- Precursores da Administração: Taylor, Ford e Fayol}

Para uma breve apresentação dos pensamentos de Taylor, Ford e Fayol foi considerada a obra de Silva (2001), que apresenta as Teorias da Administração como uma ordenação disciplinada de conhecimentos que objetivam formar a base de comportamento profissional administrativo de qualquer tipo de atividade, com auxílio de, ou sob o comando de outras pessoas.

\section{A Administração Científica de Taylor}

O livro "Princípios da Administração Científica" apresenta os estudos de Frederick Winslow Taylor, que passou de operário a engenheiro chefe, sobre a administração geral, que denominou administração científica, sem deixar, contudo, a preocupação com relação às tarefas dos operários. 
Neste estudo, Taylor assegurava que as indústrias da época padeciam de males que poderiam ser agrupados assim:

- Vadiagem sistemática por parte dos operários, com o objetivo de evitar a redução das taxas de salários, pela gerência;

- Desconhecimento, pela gerência, das rotinas de trabalho e do tempo necessário para sua realização;

- Falta de uniformidade das técnicas e métodos de trabalho dos empregados, que realizavam as tarefas cada um a seu modo.

De acordo com Taylor, a implementação da administração científica devia ser gradual e obedecer a um programa em termos de prazo, para evitar alterações bruscas que causassem descontentamento nos empregados e prejuízo aos patrões. Taylor considerava o operário como irresponsável, vadio e negligente, mas assim mesmo criou um sistema educativo baseado na intensificação do ritmo de trabalho, em busca da eficiência organizacional. Isto tudo também, para ressaltar as perdas que o país vinha sofrendo com a ineficiência e vadiagem dos operários em quase todas as atividades. $\mathrm{O}$ objetivo básico da administração científica era incrementar a produtividade do trabalhador por meio de uma análise científica sistemática do trabalho do empregado, atingindo "uma maneira melhor" de realizar tal trabalho, assegurando prosperidade para o empregador, conjugada com a máxima prosperidade para os trabalhadores. O segundo aspecto da abordagem da administração científica foi a motivação dos empregados para trabalhar o mais rapidamente possível, enquanto utilizavam "a melhor maneira" para produzir, que lhes foi ensinada.

Taylor propôs o sistema de pagamento por unidade produzida ou sistema de tarefa como solução para o problema da motivação: quanto mais peças o trabalhador produzisse, maior seria a sua remuneração. A idéia básica era que, em termos de incentivos, cada trabalhador, individualmente, seria pago por resultados. Isto era contra as normas dos sindicatos, que obtinham solidariedade coletiva, e assim tendiam a deslocar o que Taylor acreditava ser um desejo natural de homens de primeira classe por ganhos materiais e progresso pessoal, baseados nos seus próprios talentos e aplicação. Taylor desaprovava qualquer noção de conflito endêmico entre capital e trabalho, atacando este relacionamento (entre capital e trabalho), em vez de tratá-lo como algo de interesse mútuo. A colaboração entre gerentes e trabalhadores garantiria o sucesso do empreendimento e proveria crescimento econômico, com benefícios para todos. A especialização do operário foi, para Taylor, um dos 
principais pontos para o desenvolvimento do processo de produção na administração científica.

Ainda com o objetivo de eliminar todos os elementos estranhos para que a atenção estivesse concentrada na tarefa essencial, Taylor propôs o conceito de administração funcional, pelo que a tarefa da supervisão, por exemplo, deveria ser subdividida entre os vários supervisores especializados (especialistas em suas atividades), responsáveis pelo controle de diversos aspectos do trabalho.

Taylor viu a oportunidade de aplicar a disciplina, a objetividade e a racionalidade do engenheiro na solução dos problemas administrativos. Ele queria reduzir o acaso, a "regra do polegar" (isto é, o empirismo no processo de produção) e os fatores de personalidade na tomada de decisão. Taylor defendia a administração por sistemas e padrões.

Do seu livro, "Princípios da Administração Científica", Taylor via a administração científica de modo amplo:

Administração Científica consiste fundamentalmente de certos princípios gerais amplos, uma certa filosofia, que pode ser aplicada de muitos modos e, uma descrição do que quaisquer homem ou homens possam acreditar ser o melhor mecanismo para aplicação destes princípios gerais, o que de modo algum pode ser confundido com os próprios princípios. Um princípio para Taylor é uma declaração básica ou a verdade fundamental, que promove entendimento e orientação para os pensamentos e prática, explicando o relacionamento entre o conhecimento e a predição dos fatos. Entretanto, a sociedade talvez não estivesse preparada para mudanças em tal nível, e a atenção rapidamente se voltou para as técnicas mais facilmente implementadas de Taylor. Estudiosos de eficiência espalharam pelo país estudos de performance de movimento e tempos, sem o acompanhamento das mudanças fundamentais na filosofia gerencial. Taylor identificou as seguintes características da administração científica:

- Ciência em lugar do empirismo;

- Harmonia em vez de discórdia;

- Cooperação, não-individualismo;

- Máxima produção e não-restrição de produção;

- Desenvolvimento de cada homem para a sua máxima eficiência e prosperidade. 
Observa-se que Taylor em sua obra "Scientific Management", tornou-se alvo visível demais para os humanistas ao afirmar coisas como: "Um dos primeiros requisitos necessários para um homem que deve manejar ferro é que ele seja tão estúpido que mais se pareça com o boi do que qualquer outro tipo, portanto, ele deve ser treinado por um homem mais inteligente do que ele". Esse tipo de declaração deve ter contribuído de forma negativa, desde aqueles tempos, para uma busca mais humanista na crença da participação do homem no trabalho, como uma forma de melhorar a prática da administração e também para amenizar os efeitos da racionalização do trabalho proposta pela administração científica.

\section{A Administração de Ford}

Henry Ford não era nem engenheiro, nem economista, nem psicólogo; era um empresário com visão prática, que buscava a cristalização do conceito da eficiência, no mais amplo sentido, numa fábrica de automóveis. A empresa, na visão de Ford, do mesmo modo que na de Taylor, divide-se em dois níveis distintos: planejamento e execução.

No planejamento, os técnicos elaboram os métodos e o próprio trabalho; na execução os operários só efetuam o trabalho que lhes é levado às mãos. Assim, pode-se dizer que "é o trabalho que dirige a empresa".

Enquanto no sistema de Taylor o operário executava, num tempo padrão, movimentos regulados e prescritos pela administração de planejamento, no sistema de Ford o operário adaptava seus movimentos à velocidade da esteira rolante, sendo naturalmente conduzido em ritmização involuntária, de acordo com o nível de produção. Enquanto Taylor se preocupava demasiadamente com a "economia do trabalho humano", Ford se preocupou com a "economia de material e do tempo". O que caracterizou Ford foi ter utilizado todas estas contribuições e posturas, com o objetivo de tornar sua empresa eficiente, compreendida a eficiência de um lado como produção, motivação e salário, e, de outro, como custos e preços mínimos.

O modelo administrativo de Ford se caracteriza pelo trabalho dividido, repetido, contínuo, baseando-se nos princípios da produtividade, da intensificação e da economicidade.

Dois deles se referem ao "tempo": produtividade e intensificação; o terceiro se aplica ao fator "matéria": economicidade. A política de Ford se alicerçou na produção em massa, em série e em cadeia contínua; no pagamento de altos salários e na fixação de preços mínimos para os bens produzidos. Tudo isto apoiado na elevação da produtividade do 
operário, aumento da intensidade de produção e economia máxima de material e de tempo de fabricação. Ford estabeleceu um processo de trabalho contínuo e o automóvel fabricado era vendido antes de serem pagos os salários e as matérias-primas nele utilizadas. $\mathrm{Na}$ sua linha de montagem implantada em 1913, saía um carro a cada 84 minutos.

A empresa Ford assombrou o mundo pela velocidade de fabricação, pelo preço de venda (bastante reduzido para a época) e pela grandiosa produção anual, o que ocorreu pela introdução do conceito de eficiência como objetivo da administração. Daí adveio um original interesse de bem-estar do trabalhador. Uma das razões principais do sucesso de Ford foi atenção dispensada ao pessoal de alta competência; ele se cercou de técnicos de elevada capacidade em todas as atividades necessárias ao êxito da fábrica.

Em face do interesse que sempre demonstrou pelos problemas do seu pessoal, visivelmente pela revolucionária aplicação de benefícios salariais e assistenciais (inéditos no seu tempo), Ford pode ser considerado um precursor da Escola das Relações Humanas. Para Ford, a administração, sobretudo através do planejamento, precede ao homem: "Quem dirige é o trabalho, não o homem. A questão é conservar todas as coisas em movimento, de modo que o trabalho vá ter ao homem e não o homem ao trabalho".

\section{A Teoria Administrativa de Fayol}

Henri Fayol, um engenheiro de minas, passou sua vida inteira trabalhando na mesma empresa e começou a desenvolver suas idéias sobre administração em 1900 e, num folheto apresentado no Congresso Internacional de Mineração e Metalurgia, disse:

“Todos os empregados numa organização participam, num maior ou menor
grau, da função administrativa... (e) têm oportunidade para exercitar suas
faculdades administrativas e serem reconhecidos por isto. Aqueles que são
particularmente talentosos podem subir dos degraus mais baixos aos mais
altos, da hierarquia da organização." (FAYOL).

Nos seus escritos iniciais podia-se notar a importância da habilidade administrativa para o desempenho organizacional. Fayol definiu teoria como "uma coleção de princípios, regras, métodos e procedimentos testados e verificados por experiência geral". Da sua longa experiência, ele notou que um grupo de administradores teorizava, mas, na prática, existiam muitas contradições e pouquíssima reflexão sistemática. Isto ajudou a dificultar o ensino e a prática da administração. Fayol assegurava que: "Qualquer organização necessitava de administração, fosse do tipo de comércio, indústria, política, religião, militar ou filantrópica; em qualquer condição, existe uma função administrativa a ser desempenhada". Fayol 
ressaltou a necessidade da profissionalização e do ensino da administração, usando a seguinte argumentação, válida até os dias atuais:

"A capacidade mais necessária dos agentes superiores das grandes empresas é a capacidade administrativa. Por conseguinte, uma educação exclusivamente técnica não responderá às exigências gerais da empresa, mesmo das empresas industriais. Enquanto se fazem os maiores esforços para divulgar e aperfeiçoar os conhecimentos técnicos, nada se tem feito para preparar os futuros chefes, no concernente às suas funções administrativas." (FAYOL)

Assim, Fayol registrou a relativa importância dos requisitos para as pessoas, dependendo da sua situação na hierarquia, separando em níveis as habilidades técnicas das administrativas. Ele separou a habilidade administrativa do conhecimento tecnológico. E quando em 1908 preparou um folheto para o jubileu da Sociedade Indústria Mineral, no qual maiores avanços no seu pensamento administrativo se tornaram aparentes, ele considerou que o efeito da administração sobre as atividades do negócio não foi completamente entendido e que as recomendações dos especialistas técnicos poderiam ser completamente destruídas por procedimentos administrativamente falhos. Nesse folheto Fayol externou que "um líder que seja um bom administrador, mas tecnicamente medíocre, é geralmente, muito mais útil à empresa do que se ele fosse um técnico brilhante, mas um administrador medíocre".

Nesse sentido, de acordo com Fayol, o sucesso organizacional depende mais das habilidades administrativas dos seus líderes do que das suas habilidades técnicas.

Fayol, conforme Silva (2001), definiu administração como a realização das atividades administrativas, que são as funções de previsão, organização, comando, coordenação e controle. Estas funções constituem o processo administrativo e apesar de terem passado muitas décadas desde o estabelecimento destas funções por Fayol, elas ainda são descritas como as funções administrativas. Ele considerava a previsão como a principal função administrativa. A base do processo era o desenvolvimento de um plano formal de ação, que ele descrevia como "uma espécie de quadro onde eventos próximos são definidos com alguma distinção, enquanto eventos distantes aparecem progressivamente, menos diferenciados, e isto vincula o trabalho corrente, como previsto e estipulado, em um definido período de tempo".

São considerados os princípios de administração: divisão de trabalho, autoridade e responsabilidade, disciplina, unidade de comando, unidade de direção, subordinação do interesse individual ao interesse geral, remuneração do pessoal, cadeia hierárquica de 
comando, centralização, ordem, equidade, estabilidade do pessoal no cargo, iniciativa e espírito de equipe.

Henri Fayol, a respeito dos princípios gerais da administração, ressaltou: "Não existe nada rígido ou absoluto, quando se trata de problemas da administração, é tudo uma questão de proporção".

\subsection{2- Grandes Movimentos da Era Moderna e a Natureza do Gerenciamento}

A gestão faz parte da história social e torna-se relevante compreender que, pelo menos, três grandes movimentos marcaram essa era moderna.

O primeiro movimento ocorreu ao final do século XIX até a 2a. Guerra Mundial e nesse período as empresas aprenderam a sistematizar suas experiências e técnicas. A gestão da empresa aspirava transformar-se em ciência e o gerenciamento científico visava problemas da produção; apareceram os primeiros dirigentes assalariados, as primeiras Instituições de Ensino em Administração, as primeiras revistas técnicas no assunto e as primeiras associações profissionais, nacionais e internacionais, que se consagravam ao promover a administração científica.

O segundo período ocorreu a partir dos anos 1940 e estendeu-se até o início dos anos 1980. Esse período revela o surgimento de uma sociedade de consumo de massa e as consultorias em gerenciamento, sob influência norte-americana, geraram oferta de emprego em gestão em função do crescimento das empresas e da terceirização da economia.

A era do gerenciamento moderno ocupou espaço e confundiu-se com o tipo de gerenciamento americano, que durante os anos 1960 se apoiou cada vez mais nas Instituições de Ensino de Gestão e em farto material de publicação.

A terceira fase, a partir dos anos 1980 teve como foco a busca da eficiência por questões financeiras em uma economia de mercado que se globalizava e exigia organizações sempre mais competitivas, flexíveis e informatizadas. Os operários, as técnicas e os executivos conheceram as experiências do desemprego e da instabilidade profissional. Iniciou-se a era da gestão estratégica.

Nessa busca de eficiência, em um contexto cada vez mais globalizado, a administração chocou-se com o muro das culturas organizacionais e do estilo de gerenciamento vigente e 
descobriu sobre enraizamento sócio-cultural e seus efeitos, que deveria ser investigado no sentido de favorecer o novo espírito corporativo emergente.

Como a natureza do gerenciamento é uma prática social que visa o bom funcionamento de uma organização, suas exigências têm como base a busca da eficácia, que é sinalizada por indicadores quantitativos e financeiros: lucro, rendimento do capital investido, participação no mercado, produtividade da mão-de-obra, entre outros. Essas são as exigências daqueles que dirigem ou daqueles que são os proprietários dos bens de produção.

A eficácia também depende de indicadores sociais: índice de rotatividade, nível de satisfação no trabalho, estabilidade de emprego e qualidade na saúde e na segurança. As exigências internas de eficácia são geralmente decorrentes de exigências externas, como sociais, jurídicas, ambientais, fiscais, sindicais etc., é quando as empresas consideram importante firmar compromisso em sua gestão e no seu discurso.

Hoje essas exigências estão bastante focadas em torno das discussões sobre desenvolvimento sustentável e da competitividade. Assim o gerenciamento aparece com uma prática social que coloca as pessoas em situações de relacionamento num contexto que deve ser organizado e que visa eficácia econômica antes de tudo.

Desde os primórdios do gerenciamento, a gestão utilizou as ciências humanas para responder às exigências da produtividade e da rentabilidade, e a mão-de-obra sempre foi vista como fator de produção, portanto mais um recurso.

A passagem do termo "pessoal" para a expressão "recursos humanos" e mais recentemente, para gestão de pessoas, explica essa idéia de que as exigências de eficácia mudam ciclicamente. Passou-se por uma fase taylorista considerada energética e física, depois para uma visão psico-sociológica com as relações humanas, depois para uma visão cultural e nos últimos anos, para uma visão esportiva e estratégica, pois refere-ser à performance, competitividade, ganhadores de maratonas de produtividade ou ainda à importância de manter a boa forma.

Nos anos 1980 essa preocupação com coesão e cooperação volta à tona com a força decorrente do modelo japonês de gestão e a gestão da cultura da empresa. Especialistas norteamericanos, frente a concorrentes asiáticos, cuja solidariedade no estilo de administração era visível, consideraram que a cultura e o espírito corporativo, que também Henry Fayol apreciava, representavam a solução contra o declínio das empresas norte-americanas. Entretanto, esse movimento se chocaria posteriormente com as novas realidades do 
gerenciamento desenvolvidas no início dos anos de 1980, com base na gestão estratégica e competitividade, contraditória com a preocupação de se desenvolver um núcleo solidário de trabalho e desenvolvimento.

O foco humano na maximização de resultados é apresentado no Quadro I.

Quadro I - Administração Científica e Perspectivas Humanas

\begin{tabular}{|c|l|c|c|c|}
\hline $\begin{array}{c}\text { Concepção de } \\
\text { Organização }\end{array}$ & $\begin{array}{l}\text { Administração } \\
\text { de } \\
\text { Empregados }\end{array}$ & $\begin{array}{c}\text { Sistema de } \\
\text { Incentivos }\end{array}$ & $\begin{array}{c}\text { Concepções da } \\
\text { Natureza } \\
\text { Humana }\end{array}$ & Resultados \\
\hline $\begin{array}{c}\text { Organização } \\
\text { Formal }\end{array}$ & $\begin{array}{c}\text { Identidade de } \\
\text { Interesses }\end{array}$ & $\begin{array}{c}\text { Inativos } \\
\text { Monetários }\end{array}$ & $\begin{array}{c}\text { Homo } \\
\text { Economicus }\end{array}$ & Máximo \\
\hline
\end{tabular}

Esses movimentos que poderiam afastar esforços para formação de ideais mais solidários chamaram a atenção de vários sociólogos que passaram a se interessar pela questão da solidariedade dentro das organizações. Do ponto de vista da sociologia os pesquisadores destacaram questões como identidade, socialização ou ainda, o papel que exerce a cultura nacional na lógica social da empresa. De alguma forma aparece aqui embutida a questão da solidariedade, como relação de troca e criação de condições para sobrevivência da sociedade e das organizações nela inseridas. Mais recentemente essa questão passou a ocupar importância capital em razão do aumento das taxas de desemprego, da precariedade crescente e da expansão da exclusão social que estão presentes em vários países de economia emergente e daqueles mais desenvolvidos, pois a questão é como ter senso de coletivo ou solidariedade quando o trabalho tornou-se raro.

De modo geral as empresas não podem mais se orgulhar dos benefícios generosos que elas podiam oferecer a seus empregados e possivelmente também não se orgulham de oferecer benefícios reduzidos e baixos salários. Mas possivelmente esse tem sido o caminho adotado por muitas delas na tentativa de se recuperar economicamente. 


\subsection{3- Racionalização das Práticas de Gestão}

Nos últimos dez anos observa-se uma racionalização acelerada dos modos de gestão, que toma forma de fusões, aquisições, reestruturações em massa e a utilização de técnicas que buscam reduzir o tempo de resposta e o custo operacional das empresas.

Sem dúvida os estragos de uma visão reducionista do homem, tornam identificáveis os efeitos sobre a sociedade e os indivíduos. Constata-se nesse sentido uma relação direta entre salários sob pressão e desigualdades sociais crescentes. Os salários reais não aumentam. Busca-se a alternativa de prolongamento da semana de trabalho como tentativa de se obter um ganho maior para sair das dificuldades crescentes. O contraste é ainda maior quando se trata da concentração das riquezas geradas pelas especulações nas bolsas e a posição de capitais transnacionais.

Além do salário, há a constatação de que o declínio da parte que se atribui ao trabalho na redistribuição da riqueza manifesta-se proporcionalmente na diminuição dos benefícios sociais. As coberturas de programas de aposentadoria e de saúde tornaram-se muito deficitários.

No domínio fiscal o peso da arrecadação foi transferido para os assalariados com arrecadação de impostos diretos e indiretos, principalmente quando se comparam as reduções substanciais de impostos concedidos aos detentores de capitais.

Uma outra questão diz respeito à taxa de endividamento das famílias que, por um lado está relacionado com a facilidade de obter crédito e, por outro lado, à estagnação dos salários e da política monetária mantida há anos, com taxas de juros reais elevadas para financiamentos, cartões de crédito, etc. Como os assalariados tendem a ser devedores, as políticas econômicas facilitam a transferência de riqueza para os detentores do capital: os credores.

Nas organizações, outra questão refere-se aos movimentos de reestruturação das empresas feitas em nome da eficácia que não parece ter contribuído muito para a melhoria da eficácia e produtividade nas empresas. Estudos econômicos mostram que fusões e aquisições conduziram a uma baixa de rendimento da ação na metade dos casos. Por outro lado empresas que obtiveram excelentes resultados em suas indústrias tinham estruturas estáveis.

Embora os discursos sobre novas tecnologias e resultados benéficos da reengenharia buscassem maior produtividade, não necessariamente isso aconteceu. Disso tudo vale ressaltar que as reestruturas não diminuíram a supervisão e o controle. 
E ainda os planos econômicos revelam uma lógica financeira e no jogo econômico atual, o peso dos interesses financeiros tornou-se considerável pelo volume de atividades e pela parte que os serviços financeiros se atribuem sobre lucros realizados. As conseqüências humanas advindas dos planos econômicos e outros interesses financeiros se revelam nas profundas transformações e na deterioração da coesão social. As pessoas tendem a sentir dificuldade de estabelecer relações formais e de aproximação entre colegas de trabalho. O ambiente da organização tornou-se mais rígido e racional, pois a prioridade já não é mais o trabalho em si, mas a maximização da rentabilidade em curto prazo em um mercado cada vez mais globalizado. Pode-se compreender que o nível de stress profissional aumenta, que a confiança diminui, que o cinismo desenvolve-se, que a angústia econômica ataca as pessoas e os princípios democráticos inquietam-se.

A história do capitalismo ensina que a lógica financeira predomina sobre a lógica econômica e as sociedades tendem a entrar numa zona de ameaças ou crises profundas, pois pouco é feito para se colocar um fim nessas crises. Para os administradores, no contexto organizacional, fica um desafio: ampliar a visão do ser humano embutido nessa lógica financeira, para que uma nova condição da dimensão humana, baseada nos conhecimentos e na inteligência crie raízes para uma mudança histórica.

\section{Questionamento sobre a Formação do Administrador}

Segundo Chanlat (1996:24), vinte e cinco anos após o famoso relatório da Fundação Ford que reivindicava uma real formação acadêmica e profissional, em que as ciências do comportamento ocupassem seu justo lugar, o ensino e a formação do administrador são novamente questionados. O autor observa que seja nos Estados Unidos, Canadá, França ou em outros países, existem nos diversos graus de especialização, a rigidez, a ausência de consciência histórica, a inaptidão para se comunicar ou interagir nos programas e no comportamento dos próprios estudantes. O que se sabe é que essas críticas não estão distantes da situação observada no mundo do trabalho.

Chocando-se de frente com a idealização que aparece no mundo dos negócios, a organização representa muitas vezes um lugar de sofrimento e até de violência física e psicológica, tédio ou desespero. Questiona-se o quanto a formação recebida nas universidades e as imagens criadas da sociedade global têm alimentado a racionalidade industrial e o tratamento dado aos homens e mulheres nas organizações, como recursos e como quantidades materiais, devem render de forma satisfatória, do mesmo modo que as ferramentas ou 
equipamentos. Para Chanlat (1996), associadas ao universo das coisas, as pessoas empregadas nas organizações se transformam em objetos, com pouco espaço para emergir na condição humana. Na sua visão a principal causa da invasão dessa prioridade pôde ser atribuída então, à sua subordinação ao universo dos objetos mercadorias e à racionalidade econômica.

Todo esse quadro pode esclarecer sobre um grande número de profissionais que não buscam mais se realizarem no ambiente de trabalho. Questões sobre lealdade com relação às instituições refletem a imagem de uma sociedade que convive com o individualismo, em que reinam pensamentos em curto prazo, que não se preocupa em transformar o trabalho como um meio para sustentar a vida, que se confunde com as dificuldades de acumular riquezas.

A complexidade dos problemas que se apresentam nos níveis local e global, exige uma certa solidariedade planetária, permeada de imperativos éticos que devem conduzir a um impulso em modalidades de gestão, para que elas se apóiem numa verdadeira antropologia da organização.

\subsection{4- A Administração de Recursos Humanos}

Pensar nas pessoas como cidadãos interessados no seu desenvolvimento social e humano, de um lado, e de outro, como profissionais que são produtores e difusores de conhecimentos muda radicalmente as práticas dos modelos atuais de gerenciamento e o futuro desses modelos. As pessoas estão aprendendo para melhorar as condições organizacionais e as delas próprias. Então para rever as práticas atuais torna-se fundamental a reconstrução histórica de Heloani (2003), que traz elementos para compreensão das bases que alicerçaram a Administração de Recursos Humanos e contribui para o questionamento sobre seu desafio atual, que é ir além da maximização de resultados financeiros e alcançar resultados humanos, coerentes com uma era de conhecimento e aprendizagem. Constata-se que há um avanço acelerado no desenvolvimento tecnológico, o que ocorre a passos largos, enquanto que o desenvolvimento humano encontra-se, proporcionalmente, bem aquém.

Uma apresentação compactada, dessas idéias de Heloani, revela que a manipulação da classe laboriosa pela classe dominante, com a criação de sucessivos meios de controle econômico e ideológico, é um fato irrefutável e certamente implica um esforço na manipulação da subjetividade dos trabalhadores. Tal processo de produção da subjetividade sempre envolveu - historicamente falando - alguma forma de expropriação, interligando o conceito de dominação ao de expropriação. 
No alvorecer do modo de acumulação capitalista, houve expropriação de meios de produção e a dominação foi garantida na medida em que os homens já não tinham a terra da qual extraíam seus meios de vida, só restando-lhes a venda de sua força de trabalho. Para a instauração de um processo de dominação, faz-se necessário que haja algo que o outro não tem, mas que é de especial importância para sua sobrevivência. Ou talvez seja necessário desapossar alguma coisa fundamental ao outro, de modo que não lhe reste alternativa de ação a não ser submeter-se às "regras do jogo" de seu expropriador. Normalmente, a submissão é simples estratégia de sobrevivência. Entretanto, a lógica dialética ensinou que toda dominação é processual, portanto transformadora e transformada, e passível de resistência e conflito. $\mathrm{Na}$ forma de acumulação primitiva, isso fica patente ao se observar como por vezes ela ocorreu de forma violenta, em consonância com a escassez de força de trabalho industrial.

A necessidade de intensificar a força de trabalho para atender à enorme expansão da demanda na Revolução Industrial trouxe a expropriação da força bruta humana pela mecânica. Posteriormente, numa tentativa de organização e aceleração da produção, no intuito de aumentar os ganhos do capital, procurou-se obter o "saber-fazer" operário, transformar o "saber-tácito", em saber técnico-empírico, fundamentado nas experiências e habilidades manuais e mecânicas do trabalhador, evoluindo para a apropriação do conhecimento de maneira ampla. O domínio do "saber-fazer" pelos assalariados dava-lhes força reivindicatória perante o patronato e, por conseguinte, ao capital em geral. No processo de apropriação operado pelo capital, toda uma cultura operária relativa a esse conhecimento empírico, transmitido de trabalhador para trabalhador, passa a ser utilizada em favor do crescimento da produção capitalista. Essa estratégia, que muito deve ao "saber-tácito" do operariado, ficou conhecida como taylorismo e encontrou sua continuidade e otimização mediante o acréscimo da variável tecnológica representada pela esteira do fordismo.

Com a contribuição de Heloani (2003), tem-se uma visão de que nos anos 1960, a "fuga do trabalho" foi uma marca significativa da resistência da classe trabalhadora, descontente com a crescente automação fundada na intensificação do trabalho nas fábricas, que implicava contínuas acelerações da cadência de trabalho, além da catástrofe do desemprego. A reação a essa situação foi o pós-fordismo, por meio do qual se organizou uma ofensiva do empresariado com o intuito de reestruturar o processo produtivo a seu favor, atacando basicamente em três frentes macroeconômicas: redução do Estado-Previdência, globalização da produção e desindexação dos salários. Sua teoria, então, é a de que o pósfordismo veio não só como uma resposta do capital à "crise do sistema de regulação", mas 
também como forma de buscar outros meios de garantir a continuidade da dominação da classe trabalhadora.

O progresso tecnológico pôde então ser visto como um movimento contraditório e conflituoso inserido num processo histórico de luta de classes. Nesse contexto, a chamada "gestão participativa" foi de fato uma resposta "interessada" do capital - que num momento de dura crise na produtividade do trabalho no Ocidente, voltou-se para uma nova forma de "envolvimento" do trabalhador no processo de produção. Acredita-se que o reordenamento da subjetividade no interior do processo laborativo serve não só para otimizá-lo dentro do quadro de globalização do capital, mas também para garantir, em outras bases, seu domínio sobre a força de trabalho. Nesse novo modelo de desenvolvimento da produção, a expropriação da capacidade intelectual do trabalhador é tão importante quanto o foi o domínio sobre sua capacidade física no modelo taylorista-fordista-fayolista.

Heloani (2003) considera que ao contrário do que apregoam os apologistas da sociedade do lazer, sociedade pós-industrial e congêneres, que vêem na lógica amplamente utilizada pelo modelo pós-fordista um elemento libertário, emancipatório do ser humano, talvez seja pura utopia. Isso porque os fundamentos e preceitos do pós-fordismo são, em sua essência, muito semelhantes aos da lógica taylorista. Apenas mais sutis, mas bem maquiados e, portanto, mais perigosos, pois de certa maneira agora o trabalhador compartilha a própria dominação. O neoliberalismo, como elemento imprescindível para a consecução do pósfordismo, tenta apresentar-se como projeto técnico, apolítico, quando, em verdade, é eminentemente político em suas ações e objetivos.

Essa contribuição é muito relevante para que a compreensão do pós-fordismo em qualquer de suas versões - oriental ou ocidental - de que ele não representa a morte do taylorismo. Na verdade, não difere, na maioria de seus aspectos e princípios, do taylorismofordismo.

Os elementos que passaram a orientar a resposta do Capital na relação Trabalho/Trabalhador são apresentados no Quadro II a partir uma linha histórica de grandes marcas em um século das teorias administrativas. 
Quadro II- Teorias Administrativas e Nomenclatura da Relação Trabalho/Trabalhador.

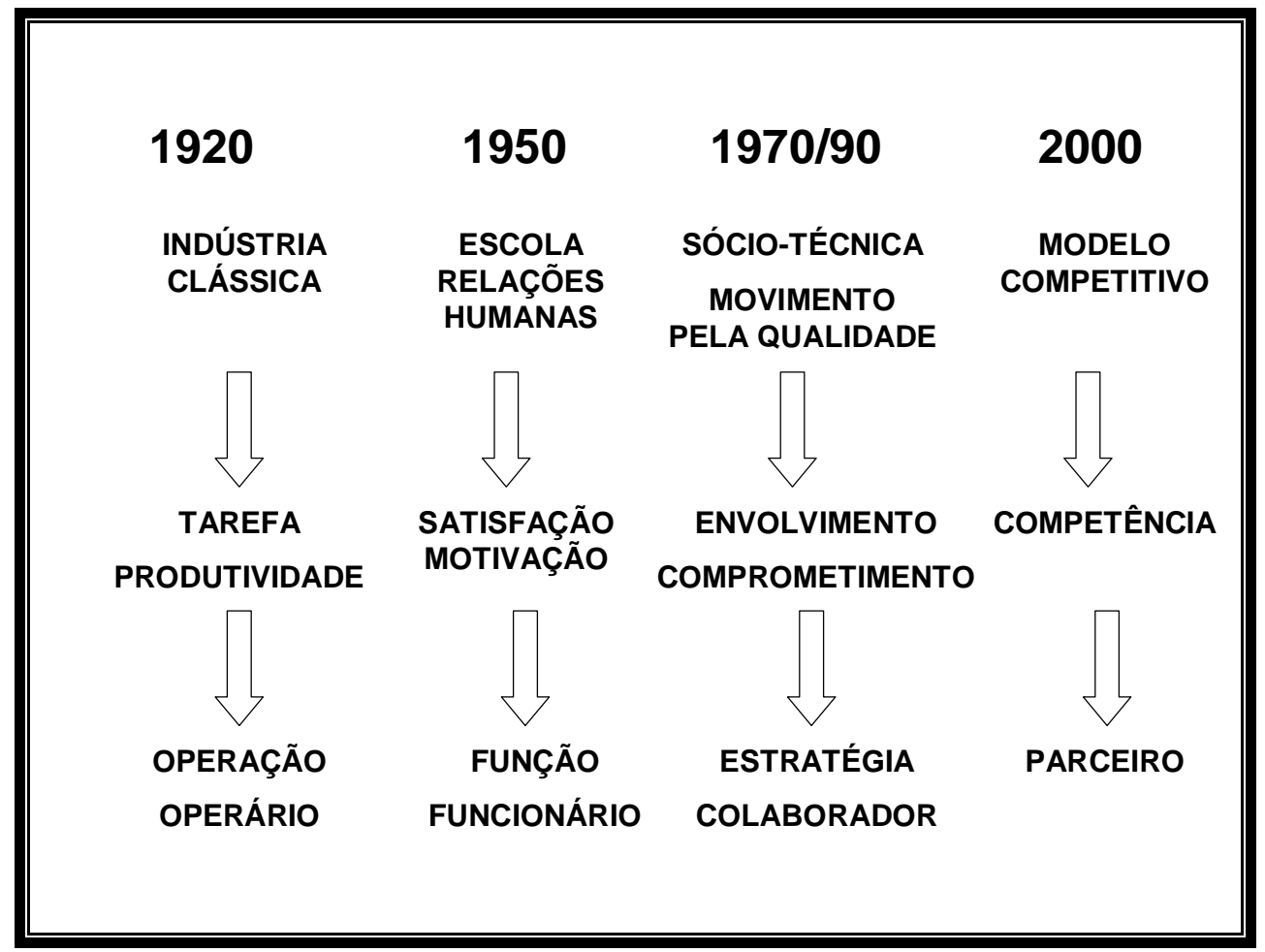

\section{Empresas Brasileiras e o Histórico Político}

A realidade das empresas brasileiras pode revelar uma inferioridade ou desigualdade nas formas de gestão de pessoas, quando comparada uma às outras, principalmente pelo histórico político do país.

O enfoque de políticas e gestão de recursos humanos se debate entre a concepção funcional mecanicista e a nova concepção de desenvolvimento e aprendizagem. Considerando a influência do modelo da administração gerencial, numa visão clássica, a área de recursos humanos, objetiva com a aplicação de políticas e realização de programas de desenvolvimento, otimizar os recursos humanos para garantir competitividade organizacional. Esse processo ocorre intermediado por processos de mudança organizacional, que dependem de contextos internos e externos. O contexto interno inclui estruturação de negócio, segmentação mercadológica, padrões da cultura organizacional e do processo de comunicação interna. O contexto externo se refere à interação com mercados, governo, conjuntura econômica e valores sociais, políticos e culturais vigentes.

Conforme Dessler (2003), no início do século XX, os primeiros departamentos de recursos humanos ou "áreas de pessoal" controlavam as admissões e as demissões feitas pelos 
supervisores, dirigiam o departamento de pagamentos e administravam planos de benefícios. Era esse o trabalho, que em grande parte consistia em assegurar que os procedimentos fossem seguidos. Quando a tecnologia passou a ser introduzida no ambiente de trabalho verificou-se a necessidade de novos conhecimentos e habilidades para o perfil dos trabalhadores e, conseqüentemente, a área de RH introduziu nas suas rotinas os testes e as entrevistas, ampliando sua especialidade em seleção, treinamento e avaliação dos funcionários.

O peso da legislação dos sindicatos na década de 1930 levou a uma segunda fase da área e a uma nova ênfase de proteção à empresa na sua interação com os sindicatos. A legislação sobre discriminação do trabalhador nas décadas de 1960 e 1970 levou a uma terceira fase da administração de pessoal, pois em função de grandes prejuízos que ações judiciais poderiam causar à empresa, as práticas efetivas em relação ao pessoal tornaram-se mais importantes, sendo criadas em muitas empresas a área de relações sindicais.

Nesse período o departamento de recursos humanos oferecia especialização em áreas como recrutamento, seleção, treinamento, mas observa-se, porém, que negociando com sindicatos ou empregando de maneira mais criteriosa, a "área de pessoal" ganhou status daquele que tanto poderia proteger a organização de problemas legais com relação aos funcionários quanto poderia contribuir de forma eficaz para influenciar nos rumos da capacidade produtiva e da competitividade da empresa.

Nos últimos anos "a área de pessoal" entrou em uma quarta fase, e seu papel mudou: de protetora para planejadora, abarcando uma conotação de agente de mudanças. A metamorfose da "área de pessoal" ou de departamento de recursos humanos para administração de recursos humanos reflete o fato de que nas organizações atuais, com estruturas mais achatadas, na busca de melhores condições de competitividade e voltadas para o downsizing, são os funcionários altamente capacitados e comprometidos com o desenvolvimento de novas competências, e não apenas as máquinas, que constituem o principal fator para a sobrevivência da empresa.

Tudo isso significa que se tornou muito importante para as organizações saberem contratar as pessoas certas, promoverem sua capacitação e motivarem-nas efetivamente. E isso, por sua vez, demanda um sistema de administração de recursos humanos também mais efetivo. As melhores práticas de RH para muitas empresas hoje em dia, incluem contratação altamente seletiva, capacitação de equipes de trabalho para tomadas de decisão descentralizadas, altos salários, treinamento extensivo, diminuição das diferenças de status entre superior e subordinado e muito compartilhamento de informações entre funcionários e 
gerência - tudo isso construído como uma base para que se entenda que não basta ver as pessoas como uma fonte de vantagem competitiva, mas que é necessário criar uma cultura administrativa que adote essa crença.

Assim como as demais áreas da empresa, a Administração de Recursos Humanos também sofre influência do Ambiente Externo e, portanto, precisa estar preparada para responder às constantes alterações e necessidades.

Cabe ao RH se preparar para capacitar os gestores de pessoas, no sentido de que eles possam corresponder às alterações impostas, promovendo a sua integração e sua familiarização com novos modelos de gestão de pessoas, voltados para valorização dos conhecimentos e para qualificação do profissional, que hoje é reconhecida na capacidade apresentada pelo funcionário de agregar valor ao produto ou serviço oferecido pela empresa.

Considerando o histórico da área, houve uma fase que coube exclusivamente ao RH a responsabilidade pela contratação e administração dos funcionários. Na década de 1990, com ênfase na administração estratégica, Wood Jr (1992:33) observou que “a Administração de Recursos Humanos está sendo vista como o centro do desenvolvimento da empresa, centrada no funcionário e na premissa de que a qualidade na liderança e nas relações humanas contribui, decisivamente, para o bom desempenho dos negócios da empresa”.

Não há como negar a importância de discutir o papel da Administração de Recursos Humanos no contexto de economia globalizada e interesses de competitividade das organizações, entretanto no Brasil, a Administração de Recursos Humanos possui uma trajetória que resulta da evolução do pensamento do país. Para uma melhor compreensão deste fato observa-se que final da década de 1980, a visão sobre a área foi revelada por Albuquerque (1987):

Teve sua evolução marcada pelas limitações da legislação trabalhista, pela importação de técnicas de administração de pessoal de países desenvolvidos, pela ausência e manipulação no movimento sindical durante muitos anos, e pela influência de variáveis ambientais, externas à organização. (ALBUQUERQUE, 1987: 05).

\section{Evolução da Administração de Recursos Humanos no Brasil}

Torna-se relevante para este trabalho essa descrição de alguns períodos marcantes da evolução da Administração de Recursos Humanos no Brasil, em forma de breve relato, visto que, segundo Aquino (1984:63), “é difícil e até mesmo impossível saber o que está 
acontecendo atualmente nas relações trabalhistas brasileiras sem o recurso da História, pois os fatos atuais têm causas bastante remotas".

Considerou-se para efeito dessa tese uma análise histórica da Administração de Recursos Humanos marcada por três grandes fases:

\section{De 1930 a 1945}

Durante o Governo Interventor de Getúlio Vargas (1930-1945), ocorreu a promulgação de uma série de Leis Trabalhistas e criou-se o Ministério do Trabalho, Comércio e Indústria, com o intuito de regular as relações entre empregados e patrões, o que, na visão de Albuquerque (1987:04), "limitava a atuação do movimento operário e conferia à Administração de Recursos Humanos um papel essencialmente protocolar”.

Este período histórico exigia um estilo de Administração de Recursos Humanos adequado às regras e leis vigentes à época. Conforme observam Fleury e Fischer (1992:08) “as empresas do setor industrial começaram a criar, desde 1930, as 'Seções de Pessoal', que burocratizaram os aspectos jurídico-legais da relação empregatícia”. A Seção de Pessoal e, conseqüentemente, o Chefe de Pessoal surgiram como exigência de uma época em que a parte burocrático-legal era muito importante para o tratamento das questões relacionadas às relações trabalhistas.

\section{De 1945 a 1964}

Com o avanço da industrialização no país, surgem novas exigências com relação à organização do trabalho para responder, principalmente, à evolução tecnológica que se apresentava. Com isto, neste período do trabalhismo brasileiro, surge a necessidade de um profissional de Recursos Humanos diferenciado do Chefe de Pessoal. Isto implicou, conforme observa Saldanha (1975:02) apud Albuquerque (1987:04), "na importação de técnicas e conceitos de administração de pessoal de países mais desenvolvidos e a substituição do 'Chefe de Pessoal' pelo 'Administrador de Pessoal'”. Esta nova denominação conferiu ao profissional da área uma nova dimensão, visto que segundo Cordeiro et alii (1967:09 apud ALBUQUERQUE 1987:04), “métodos como a descrição de cargos, a avaliação de desempenho e a pesquisa salarial, entre outros, passaram a incorporar seu vocabulário".

No final da década de 1950, com o Plano de Metas do governo Juscelino Kubitschek, instalaram-se no país as empresas de capital multinacional que, como observam Fleury e Fischer (1992:09), “foram atraídas por isenções e incentivos à instalação, mão-de-obra barata e mercado interno consumidor". Nessa ocasião começa a se formar no país um parque 
industrial de tecnologia avançada trazida por essas empresas, o que passou a exigir, conseqüentemente, uma mão-de-obra mais qualificada, além de novas formas de gestão desta mão-de-obra. Segundo Aquino (1984:67), "havia a necessidade de se estruturarem outras unidades de recursos humanos, com qualidade e técnicas capazes de enfrentar a nova realidade". É neste momento de transição, conforme Albuquerque (1987:04), "que o administrador de pessoal é substituído pelo gerente de Relações Industriais, à moda das empresas americanas ou, de maneira mais adequada, pelo Gerente de Recursos Humanos".

\section{De 1964 a 1990}

A instauração do Regime Militar no Brasil redundou em profundas transformações sociais e econômicas que, de uma forma ou de outra, afetaram as organizações, visto que, de acordo com Fleury e Fischer (1992:10): “o Estado passou a intervir diretamente para direcionar os investimentos privados". Segundo as autoras, "nesta época, as empresas trabalhavam em condições propícias ao estabelecimento de políticas organizacionais que não visavam à valorização dos recursos humanos e tendiam a depreciar o fator trabalho". Esta situação relegou o administrador de recursos humanos a um papel secundário e de apoio às demais áreas das organizações.

No final da década de 1970, profundas mudanças ocorreram em decorrência dos movimentos sindicais no ABC paulista, que trouxeram de volta o sindicalismo enterrado pela Revolução de 1930. Neste período, conforme observam Fleury e Fischer (1992:11), "o nível de educação formal e o grau de informação do trabalhador elevaram-se, acionando posturas mais participativas e reivindicatórias". Isto exigiu, por outro lado, uma postura diferenciada da Administração de Recursos Humanos das empresas, mais voltada às formas de organização do trabalho e às dificuldades de relacionamento existentes entre patrões e empregados. Para as autoras, "não havia expectativa de transformação nos padrões de relação de trabalho, nas formas de organizar o processo de trabalho e na ação organizada da classe trabalhadora".

Com essa descrição breve da evolução da Administração de Recursos Humanos no Brasil, percebe-se que as variáveis ambientais, representadas principalmente pelos momentos históricos da trajetória sócio-econômica e política brasileira, influenciaram marcadamente nesta evolução. Muitas vezes parece que faltam aos profisssionais de Administração de Recursos Humanos um engajamento com reflexões mais críticas a respeito de seu papel ou de sua competência em novos contextos e na realidade global e local. 


\section{Profissionais de Administração de Recursos Humanos}

Em se tratando de Recursos Humanos no Brasil os profissionais que atuam na área participam de empresas, principalmente multinacionais, que adotam posturas inovadoras de gestão de pessoas e de outras que ainda mantêm uma postura, considerada como tradicional e obsoleta. Segundo Wood Jr et alli (1997:78), “O Brasil é um país de contrastes. Temos empresas de ponta que convivem com setores em que os procedimentos de gestão empresarial ainda são vistos com reserva".

Sobre os profissionais da área de Recursos Humanos, Heloani (1999:48) afirma que:

(...) alicerçando-se em pressupostos teóricos hoje bastante discutíveis, na medida em que, ao privilegiar, de forma obsessiva [...] temas como produtividade, competitividade e lucratividade, mostram-se presos a uma postura positivista calcada na análise de variáveis quantitativas que ignoram ou desprezam, às vezes as duas coisas, as implicações mais amplas das transformações em curso. (HELOANI 1999: 48).

Nessa reflexão sobre o processo ocorrido, verifica-se a importância da Administração de Recursos Humanos como mediadora entre os interesses da organização e o interesse dos funcionários envolvidos nesse processo de mudança contínua. Parte-se da idéia que a organização por si só não existe, mas é um conjunto de pessoas e que se vale delas para o alcance de seus objetivos. Quando uma empresa estabelece o caminho que ela irá seguir nos próximos anos, a sua estratégia organizacional e as competências essenciais que lhe darão sustentação e reconhecimento, torna-se fundamental que ela conte com pessoas, cujos objetivos individuais devem estar alinhados com as perspectivas de aproveitamento e crescimento no contexto do futuro da organização.

A Administração de Recursos Humanos teve importância vital para a transformação e a busca do aumento da competitividade ao longo das últimas décadas. Como observa Hathcock (1996:246), "numa constante revisão do ambiente", visando antecipar-se às mudanças, cria marcas profundas no contexto empresarial, visto que, conforme Almeida et alli (1993:21): “(...) tudo o que é realizado em uma organização provém de atos e decisões de pessoas, e que por si só podem ser realizados de uma forma melhor ou não". O papel de gestão de pessoas, em nível estratégico torna-se mais importante ainda, visto que, segundo os próprios autores, “a diferença desta performance está, normalmente, na qualidade administrativa destas pessoas, e que irá determinar o sucesso ou não da organização. (ALMEIDA et alli 1993:21). 


\section{Papel Atual de Administração de Recursos Humanos}

Talvez a mais surpreendente mudança no papel da área de Recursos Humanos seja seu crescente envolvimento no desenvolvimento e na implementação de estratégias. Há alguns anos, a estratégia - o plano da empresa no que diz respeito ao modo como ela equilibra suas forças e fraquezas internas com as oportunidades e as ameaças externas para manter uma vantagem competitiva - era um trabalho para os gerentes de operação (de linha) da empresa. Assim, eram o presidente e seu staff que decidiam entrar em novos mercados, acabar com linhas de produtos ou adotar um plano de redução de custos de cinco anos.

Hoje as estratégias dependem cada vez mais do fortalecimento da competitividade organizacional e da formação de equipes de trabalho comprometidas, e isso coloca a área de Recursos Humanos em um papel central.

Em um ambiente industrial com mudanças rápidas, com ambiente globalmente competitivo e com orientação para a qualidade em geral, considera-se que são os funcionários da empresa e seus recursos humanos que possam oferecer a chave para a competitividade. É cada vez mais comum envolver a Administração de Recursos Humanos nos primeiros estágios do desenvolvimento e da implementação do plano estratégico da empresa, em vez de deixá-lo apenas reagir a ele.

\section{Administração Estratégica de Recursos Humanos}

O fato de os funcionários serem hoje fundamentais na busca de vantagem competitiva levou à criação da administração estratégica de recursos humanos. Ela tem sido definida como "a união da administração de recursos humanos com metas e objetivos estratégicos para melhorar o desempenho da empresa e desenvolver culturas organizacionais que encorajam a inovação e a flexibilidade". Em outras palavras, ela é "o modelo de atividades de recursos humanos desenvolvido com a intenção de permitir que a organização alcance suas metas".

A administração estratégica considera a área de Recursos Humanos como uma parceira estratégica na formulação das estratégias da empresa, assim como na possibilidade de implementação dessas estratégias por meio de uma série de atividades consistentes de RH realizadas internamente, como recrutamento, seleção, treinamento e remuneração de pessoal. O termo "estratégias de RH” refere-se aos cursos de ação da área de RH que são específicos 
para o que a empresa planeja e estabelece como seus objetivos. Assim, a estratégia de RH é voltada para a construção de uma força de trabalho comprometida com os objetivos organizacionais.

Alguns componentes específicos da estratégia de Administração de Recursos Humanos seguem algumas metas básicas:

- Usar vários mecanismos para obter comunicações de mão-dupla saudáveis;

- Demitir gerentes cujos valores não sejam orientados para as pessoas;

- Garantir o melhor tratamento possível e segurança no trabalho para todos os funcionários e

- Instituir várias atividades com o objetivo de oferecer aos funcionários todas as oportunidades possíveis para que eles utilizem seus dons e habilidades no trabalho.

No plano ideal, a área de Recursos Humanos e a alta administração trabalham de maneira interativa para formular as estratégias de negócios da empresa. A estratégia da empresa deve prever uma estrutura de acordo com as responsabilidades de RH, pois recrutamento e seleção, avaliação de desempenho, treinamento, e remuneração devem estar integradas. Se essa integração é implementada com sucesso, ela deve contribuir para o desenvolvimento das competências e dos comportamentos exigidos dos funcionários, que por sua vez devem contribuir para a empresa implementar suas estratégias e alcançar suas metas de maneira eficiente. Observa-se que é na clareza das estratégias da empresa e na formulação das práticas de $\mathrm{RH}$ que a administração tem mais influência direta no desenvolvimento de seus profissionais, pois ela pode influenciar o comportamento e o desejo dos funcionários por meio das práticas que implementa.

\section{Recursos Humanos como Parceiro Estratégico}

O fato de ao longo de sua história a área de RH ter tido um papel consultivo ou de assessoria, a deixou com uma reputação de certa maneira empobrecida: alguns ainda tendem a vê-la como algo menor do que ele realmente é.

De modo geral, nas empresas algumas pessoas acham que a área de Recursos Humanos é estritamente operacional e que suas atividades não são estratégicas. Nessa linha de pensamento ultrapassado, conforme Marras (2000) as atividades da área de RH simplesmente 
envolvem a realização de pequenas atividades, como garantir que as pessoas recebam no dia certo, fazer o anúncio de emprego chegar ao jornal no prazo estipulado, recrutar o supervisor adequado para o turno da noite e ajudar o gerente a se lembra de observar o processo antes de demitir o representante novo que não tem tido um bom desempenho.

Uma visão mais sofisticada da área de $\mathrm{RH}$ é que seu papel é simplesmente "ajustar" a estratégia da empresa. Segundo essa visão, o papel estratégico do RH é adaptar as práticas de recursos humanos (recrutamento, recompensas e outros) para ajustar as estratégias competitivas e empresariais específicas. Por essa ótica, a alta administração desenvolve uma estratégia empresarial e o RH é convocado para criar os programas de recursos humanos necessários para a implementação bem sucedida dessa estratégia empresarial.

Como apontam Hamel e Prahalad (1995:176) especialistas da Harvard Business School, "O sistema de administração de recursos humanos deve ser desenvolvido sob medida para as demandas da estratégia empresarial". A idéia é que "para cada estratégia organizacional em particular haja uma estratégia de recursos humanos".

Uma terceira visão da administração da área de Recursos Humanos diz que ela é uma parceira no processo de planejamento estratégico. Nesse caso, o papel da administração de recursos humanos não é simplesmente desenvolver atividades sob medida para as demandas da estratégia empresarial ou efetuar tarefas operacionais do dia-a-dia, como por exemplo, garantir que os funcionários recebam. Em vez disso, há necessidade de moldar a força de trabalho da empresa para que esta se torne uma vantagem competitiva, o que significa que a administração de recursos humanos deve ser um parceiro tanto na formulação como na implementação das estratégias organizacionais e competitivas da empresa.

\section{O Futuro Estratégico da Área de Recursos Humanos}

Para Dessler (2003:18), “ironicamente, embora a necessidade da área de Recursos Humanos seja obviamente grande e crescente, o futuro da área às vezes parece incerto". $\mathrm{Na}$ sua visão os departamentos de RH passarão por downsizing e reengenharia, uma vez que eles sofrem uma grande pressão por parte da gerência sênior para agregar valor à organização ou ter suas funções terceirizadas. $\mathrm{O}$ autor questiona o que os departamentos de $\mathrm{RH}$ podem fazer para se manter longe das terceirizações e propõe que a área de Recursos Humanos se volte menos para as funções administrativas e de manutenção tradicionais, como recrutamento, 
testes e folhas de pagamento e se volte mais para as atividades que agregam valor à linha de rendimentos da empresa - atividades como planejamento estratégico, administração de mudanças, transição da cultura empresarial e desenvolvimento do capital humano.

Quadro III apresenta uma adaptação ao trabalho de Tose, considerando-se as novas tendências de aprendizagem a partir do início do século XXI. No início do ano de 2000, com ênfase no conhecimento e novas responsabilidades, uma nova fase para RH está centrada na parceria e na necessidade de desenvolvimento humano.

Quadro III- Recursos Humanos no Momento Presente

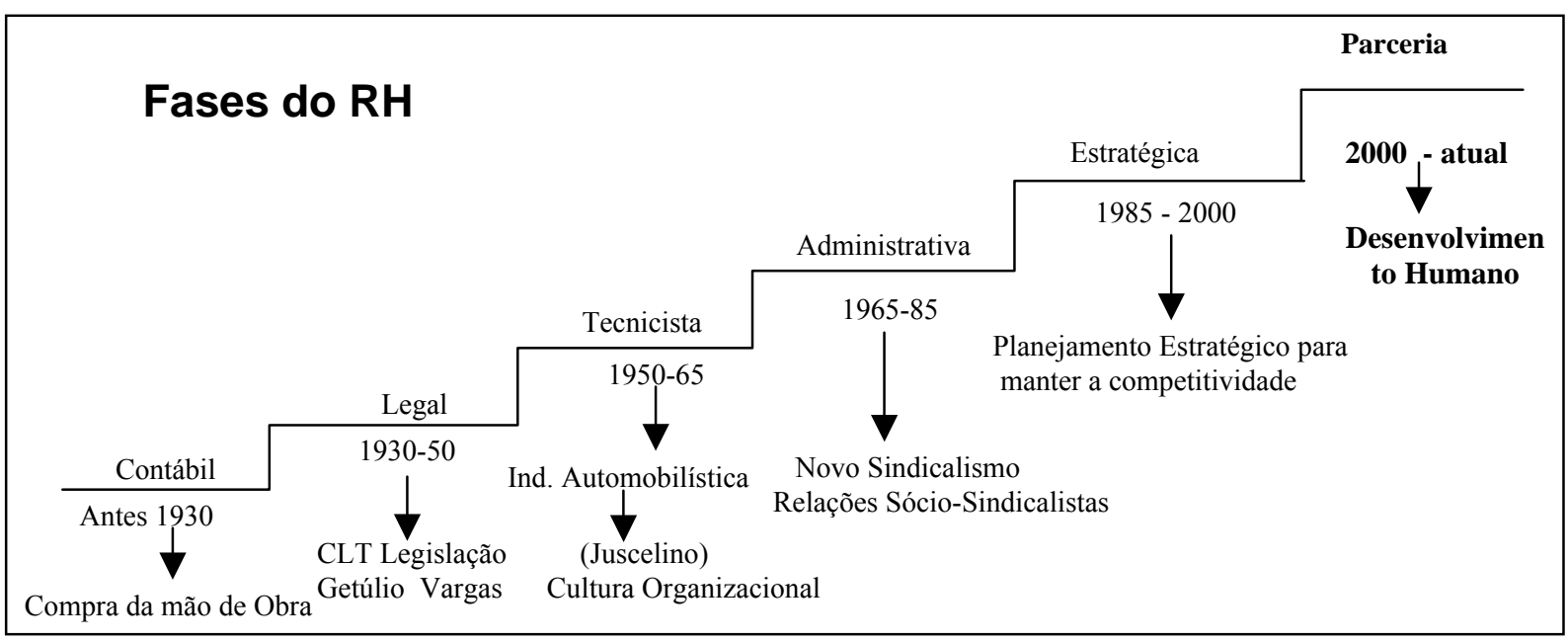

Fonte: A Autora, adaptado a partir de Tose (1997)

\section{2- O Estudo de Hawthorne (De 1924 a 1932)}

Antes de tudo trata-se de uma parada no tempo. Para Mayo, os estudos de Hawthorne revelaram que os empregados tinham sentimentos e valores e que a fábrica era um sistema social em equilíbrio, portanto o futuro da civilização dependeria de gestores dotados de sólido saber sociológico. Portanto, era no meio industrial que se podia recriar a solidariedade perdida pela desigualdade, explicada por uma ótica funcionalista, que encontra respaldo em conceitos introduzidos pela teoria de Émile Durkheim, sobre solidariedade social. Uma mudança de curso na história da gestão ocorreu e o novo caminho apontou um sentido oposto, no qual prevaleceram os conceitos de racionalidade e impessoalidade embutidos no modelo ideal de burocracia proposto por Weber. Na era industrial instituiu-se uma forma de organização do trabalho que privilegiava a divisão do trabalho (especialização), hierarquia (propulsora da eficácia), padronização (previsibilidade, inclusive do comportamento humano), 
impessoalidade (regras), meritocracia (treinamento, carreira), a idéia de que administrador é contratado para administrar contrato (carreira, salário e aposentadoria).

Mesmo assim nenhum estudo na história da Administração recebeu tanta publicidade, foi alvo de tantas interpretações e aceito, e ao mesmo tempo duramente criticado, como os experimentos conduzidos na fábrica da Western Electric Co, no bairro de Hawthorne, em Chicago, Illinois. Os estudos realizados na Western Electric constituem o mais importante programa de pesquisas do Comitê do Trabalho na Indústria, do Conselho Nacional de Pesquisas, dos Estados Unidos.

As pesquisas de Hawthorne não foram coordenadas somente por Elton Mayo, mas também por G. A. Pennock, tendo sido relatadas em 9 de março de 1938, por H. A. Wright e M.L. Putnam, da Western Eletric, e por F. J. Roethlisberger, por muito tempo professor de Relações Humanas da Harvard Graduate School of Business Administration, o mais importante dos colaboradores de Mayo.

Os relatores, assim como Elton Mayo e G.A. Pennock, como membros do comitê, tomaram parte ativa na pesquisa.Elton Mayo teve atuação destacada nos estudos e os experimentos em Hawthorne são de extrema importância na teoria das organizações.

Foi durante esses estudos que os teóricos das organizações começaram a aprender como o trabalho de grupos, as atitudes e as necessidades dos empregados afetavam sua motivação e comportamento. O programa pesquisou e mostrou a enorme complexidade do problema da produção em relação à eficiência na relação com a produtividade.

“...como trabalho de pesquisa, estes estudos estão longe da perfeição, mas
eles mostram um exemplo fascinante do método científico aplicado a
questões organizacionais, da necessidade de avaliações da hipótese e da
experimentação controlada, e da necessidade de manter a mente aberta e
questionadora enquanto na busca da verdade através da ciência. (SILVA
2001)".

Num olhar mais contemporâneo a experiência teve como base algumas premissas que eram as mesmas do pensamento de Taylor: primeiro os trabalhadores seriam estudados em unidades isoladas; segundo, o trabalhador era visto como uma máquina e sua eficiência poderiam ser cientificamente verificadas; terceiro, os fatores que influenciavam sua eficiência eram o mau controle de seus movimentos ao executar a tarefa, a fadiga e as más condições de trabalho. Importante salientar que nesse caso todo incentivo dado aos trabalhadores resumiase em torno da recompensa financeira, pois entendiam que no trabalho o homem estava buscando apenas a satisfação de sua necessidade econômica. 


\subsection{1- O Experimento na Empresa Western Electric}

A Companhia fabricava equipamentos para as empresas telefônicas e para atingir seus objetivos mostrava-se preocupada com o bem-estar dos empregados. Mantinha alto nível de salários, boas condições de trabalho e métodos reconhecidamente válidos em orientação vocacional para adaptar os funcionários às funções. Seus esforços lhe renderam em 20 anos, nenhuma manifestação de descontentamento dos empregados. Tudo leva a crer que durante a realização da pesquisa os funcionários acreditavam e confiavam na competência e nos objetivos da administração.

Os estudos de Hawthorne foram divididos em experiências com estudos de iluminação, da sala de teste de montagem de relés, programa de entrevistas e estudos da sala de observação de montagem de terminais. Estes fatos tiveram relevância para os resultados obtidos e foram desenvolvidos em quatro fases:

Primeira Fase: Os estudos de iluminação

A partir de novembro de 1924, até abril de 1927, o estudo teve como finalidade determinar a relação entre a intensidade da iluminação e a eficiência dos operários, medida em produção. Numa das experiências dois grupos de operários que faziam o mesmo trabalho em condições idênticas foram escolhidos para observação, sendo devidamente anotada a produção obtida por cada grupo. Um grupo trabalhou sob intensidade variável da luz e outro sob intensidade constante. Ao por em evidência o fator iluminação, os pesquisadores esperavam conhecer o efeito desse fator sobre o rendimento do trabalho. No sentido de mostrar uma relação direta entre luminosidade e ritmo de produção a experiência desapontou. Os pesquisadores concluíram que o resultado negativo foi obtido não porque a relação não existisse, mas porque era impossível isolar essa de outra variável que entrasse em qualquer determinação de eficiência produtiva (essa é uma dificuldade encontrada no trabalho experimental de muitas áreas de estudos). Os pesquisadores chegaram à conclusão idêntica sobre a natureza de algumas dessas outras variáveis. Um dos fatores seria o psicológico, pois os funcionários submetidos à prova reagiram às mudanças de intensidade de luz como supunham que deveriam reagir, isto é, quando a intensidade da luz aumentava, eles se julgam na obrigação de produzir mais, o contrário sucedendo quando a intensidade diminuía.

Uma nova experiência foi realizada para comprovar esse fato anterior, as lâmpadas foram trocadas por outras, com a mesma intensidade, mas fez-se crer aos operários que a 
intensidade da luz variava tal como no experimento anterior. O resultado obtido comprovou a importância do fator psicológico, pois o rendimento foi proporcional à intensidade da luz sob a qual os operários pensavam trabalhar. Ouviram-se os mesmos comentários a respeito da diminuição e do aumento de iluminação. Outras experiências se repetiram evidenciando a preponderância do fator psicológico sobre o fisiológico. A descoberta parecia ser importante, pois evidenciava que as relações entre as condições físicas diversas e a eficiência dos trabalhadores poderiam ser afetadas por relações psicológicas semelhantes.

Segunda fase: Os estudos da sala de teste de montagem de relés

Os pesquisadores prosseguiram reconhecendo a influência negativa do fator psicológico e não pretendiam dar a ele atenção especial. Na nova pesquisa não se limitaram ao campo da iluminação e passaram a observar fadiga no trabalho e efeitos sobre o trabalho com mudanças de horário ou introdução de intervalos para descanso. Por outro lado, resolveram isolar um pequeno grupo de operários numa sala, pedindo a eles cooperação, pois acreditavam que o psicológico tenderia a desaparecer, podendo-se esperar que as diferenças de rendimento de trabalho resultassem diretamente das diferenças de condições físicas. Para vencer o fator psicológico tomaram a decisão de organizar o grupo. Um pequeno número de operários foi escolhido e instalado numa sala isolada. O que se queria verificar era:

- Se os operários realmente se cansavam;

- Se era conveniente introduzir intervalo para descanso;

- Se era conveniente encurtar o dia de trabalho;

- Como eram as atitudes das pessoas em relação ao trabalho e à empresa;

- Por qual razão a produção decrescia no período da tarde.

O estudo foi organizado em treze períodos, cada um representando uma condição específica de trabalho. Existia a consciência de que estas questões poderiam ser respondidas de forma indireta e que todas elas tinham forte correlação mais com o fator psicológico do que com o fisiológico. As questões mostravam certo "desnorteamento" dos pesquisadores diante de problemas advindos das relações dos seres humanos numa grande organização industrial. Um dos diretores da empresa definindo o propósito da pesquisa, em termos mais simples e gerais, disse que o objetivo dela era "conhecer melhor os operários". Assim começou a experiência chamada "Sala de Provas de Montagem de Relés". Com essa e outras 
que se seguiram, surgiu uma íntima associação entre os membros do Departamento de Pesquisa das Indústrias da Harvard Graduate School of Business Administration.

Em abril de 1927, foram selecionadas seis moças de um grande departamento da fábrica de Hawthorne. Elas foram escolhidas entre empregadas de nível médio (nem novatas nem peritas) por trabalharem na montagem de relés de telefones. Nessa montagem, bobinas, armaduras, molas de contato e isolamento elétricos, eram colocados numa base mantida em posição por meio de quatro parafusos. Havia, na ocasião, uma média de montagem de cinco relés em cada seis minutos de trabalho. Foi escolhida essa operação porque os relés eram montados em grande número e ligeiras modificações no ritmo de produção imediatamente apareceriam nos relatórios de produção. Cinco moças realizaram o trabalho de montagem, ao passo que a sexta fornecia às demais as partes usadas na montagem para que houvesse um trabalho contínuo.

A sala de provas estava separada do departamento e as moças se sentavam, lado a lado, numa mesa de trabalho, esta era idêntica àquela utilizada no departamento, exceto num pormenor: à direita do lugar de cada moça havia um buraco (no qual deixava cair o relé montado) que era a entrada de um plano inclinado e tinha uma portinhola que se abria sob o peso do relé. A abertura da portinhola acionaria um circuito elétrico que marcava a feitura de um novo relé por meio de um furo numa fita. Essa fita constituía um registro completo de cada moça em qualquer momento do dia. Esses registros foram mantidos durante cinco anos.

Nesse ponto torna-se importante observar que nessas experiências, tal como naquelas sobre a iluminação, deu-se ênfase ao ritmo de produção. Uma informação importante é que a Western Electric não estava interessada em aumentar a produção. A experiência não tinha esse fim. Por outro lado, a produção era encarada como algo facilmente mensurável e os dados quantitativos que eram obtidos demonstraram que a produção era sensível a, pelo menos, algumas das condições nas quais trabalhavam as operárias. A produção foi tratada como índice e pela natureza das condições experimentais, a preocupação ficou centrada na ênfase do seu ritmo.

Os pesquisadores sabiam que outros fatores, além dos verificados, poderiam influir no ritmo de produção e foram providenciando outros registros e dados: peças defeituosas, registros de aparelhos montados e rejeitados pela inspeção, condições de tempo, temperatura e umidade nas salas de experiências. A cada seis semanas as moças passavam por um exame médico. Diariamente as moças relatavam sobre número de horas dormidas, alimentação, etc. $\mathrm{Na}$ sala anotavam, de hora em hora, o que ocorria. O grupo de teste desenvolveu um 
relacionamento harmonioso e a produção aumentou a despeito de intervalos ou horas de trabalho e os pesquisadores desenvolveram cinco hipóteses para explicar esta tendência:

- A melhoria das condições e métodos de trabalho na sala de testes;

- A redução da fadiga;

- As pausas foram mais eficazes na redução da monotonia do trabalho do que na redução da fadiga;

- O novo plano de salários poderia influenciar a melhoria da produção;

- A mudança no método de supervisão foi essencialmente carregada de valores sociais.

O resultado obtido foi que os valores sociais foram importantes como meios das operadoras adquirirem confiança e estabelecerem relações eficazes de trabalho junto aos supervisores. Estava evidente para as operadoras, na sala de testes, que elas eram "alvo" de atenção da alta gerência e que estavam expostas a condições de trabalho diferentes das normais.

Terceira Fase - $\underline{\text { O Programa de Entrevistas }}$

Com a introdução do "Programa de Entrevistas", cada moça passou a ser entrevistada diversas vezes por um pesquisador experiente. As moças tinham um supervisor no sentido comum e um observador da sala que verificava os dados, ordenava o trabalho e assegurava o espírito de cooperação por parte das moças. Por ocasião da instalação da sala, essas moças escolhidas já passaram por uma entrevista com o superintendente e elas tiveram todas as explicações sobre a experiência. Muitas outras ocorreram sempre que era planejada qualquer mudança e as modificações não aprovadas pelas moças eram postas de lado. Havia um estímulo para elas sentirem-se à vontade no trabalho.

Em termos gerais, os promotores da experiência achavam que, se uma curva de produção fosse observada por tempo suficiente sob diferentes condições de trabalho, seria 
possível determinar quais condições eram mais satisfatórias. A prova foi dividida em períodos experimentais:

Período I - observação por 2 (duas) semanas das condições de produção em condições normais.

Período II - transferência de local de trabalho.

Período III - modificação no sistema de pagamento e recuperação dos esforços individuais na composição do salário.

Período IV - duas pausas de 5 (cinco) minutos cada.

Período V - descanso prolongado para 10 (dez) minutos cada.

Período VI - aumento para seis pausas de 5 (cinco) minutos cada.

Período VII - lanche leve pela manhã, que foi mantido e os períodos de descanso aumentaram para $10(\mathrm{dez})$ minutos.

Período VIII - trabalho passou a terminar meia hora antes (16h30min).

Período IX - trabalho encerrava-se às 16 horas.

Período X - voltou-se ao horário do período VIII.

Período XI - semana de 5 (cinco) dias após 1 (um) ano do início da experiência.

(Nessa época, investigadores começaram a perceber que os resultados não eram os esperados. O nível de produção não refletia o que se esperava do grupo. Com a redução do trabalho em cinco dias, a produção total da semana caiu, mas a produção diária continuava crescendo.)

Período XII - com o consentimento das empregadas os pesquisadores eliminaram pausas/ refeições e voltaram ao trabalho de seis dias. Durante doze semanas observou-se a produção diária e semanal e chegou-se ao mais alto índice até então conseguido.

O que se pôde observar é que em condições idênticas de trabalho, repetidas em três períodos diferentes (VIII, X e XII), se as suposições que nortearam a experiência fossem válidas, isto é, se o nível de produção estivesse diretamente relacionado com as condições físicas do trabalhador, nos três períodos o rendimento deveria ser equivalente. Tal correlação não ocorreu e a única uniformidade evidente foi que a produção aumentou sempre de um período para outro. Possivelmente acreditava-se que algo estava acontecendo na sala de 
provas de montagem de relés, assim como já acontecera anteriormente na experiência sobre iluminação, mas esse “algo" não poderia ser explicado apenas pelas condições de trabalho.

Quarta Fase Grupo: Os estudos da sala de observação de montagem de terminais

Os investigadores sentiam que esse complexo de comportamento merecia ser investigado e em maio de 1931, um grupo de entrevistadores foi designado para trabalhar junto a grupos específicos de empregados. A história de um dos grupos é característica dos resultados obtidos com esse novo sistema de entrevistas. O trabalho desses empregados consistia no ajuste de pequenas peças que entravam na fabricação de equipamento telefônico. A administração vislumbrava esse ajuste como tarefa complicada. $\mathrm{O}$ entrevistador descobriu que o trabalho era simples e que qualquer pessoa poderia aprender, mas os empregados estabeleciam uma barreira em torno do trabalho, se orgulhavam de dizer que aparelhos que não funcionavam somente eles conseguiam fazê-los funcionar na seção para regulagem. Quando eram procurados por engenheiros complicavam a tarefa e demoravam horas para o conserto do aparelho, pois pretendiam impedir que pessoas de fora soubessem o que realmente faziam. Há dados de que os operadores confessaram aos entrevistadores sobre esse prazer em "enganar". Mantinham a administração na ignorância de volume de trabalho que poderiam realizar e a produção do grupo quando registrada era uma linha reta. Verificou-se que eles haviam desenvolvido uma organização informal e uma liderança que se encarregava de atender engenheiros e supervisores e quando uma pergunta técnica era feita sobre o trabalho, esse homem daria a resposta. O grupo dispunha de um segundo líder para assuntos internos de enquadramento dos membros para trabalhar em harmonia com o grupo e os supervisores conheciam essa situação, mas não tomavam providências, pois consideravam que não tinham poder para tal e, sempre que necessário, eles próprios se entendiam com os líderes reconhecidos dos grupos.

\section{Plano de Incentivos à Produção}

Os investigadores descobriram que o grupo nem sempre estava satisfeito com o que faziam e que havia muita inquietação sobre continuar fazendo aquele trabalho. Havia, segundo os relatos, uma percepção de inutilidade que poderia ser explicada como resultado de lealdade dividida entre o grupo e a empresa. Assim instituiu-se uma nova sala de provas lembrando-se o ocorrido anteriormente e procuraram um tipo de experiência que não fosse de radical alteração pelo processo da pesquisa. Escolheram um grupo de nove soldadores e dois inspetores incumbidos da montagem de terminais para uso das estações telefônicas e os 
passaram para uma sala especial. Um pesquisador na sala observava o comportamento dos homens. Sua função era ampliar o tipo de anotações que foram feitas no diário utilizado na "Sala de Provas de Montagem dos Relés" e utilizado pela moças na fase inicial da pesquisa. Foi designado um entrevistador que permanecia do lado de fora da sala e fazia algumas entrevistas. Observou-se que nenhum esforço foi feito no sentido de obter registros da produção além dos usados no departamento de origem e a experiência foi conhecida como "Sala das Observações de Montagem de Terminais" e durou de novembro de 1931 a maio de 1932. O primeiro aspecto que mereceu atenção na pesquisa foi o método complexo de pagamento por peças produzidas pelo grupo e acreditava-se que haveria possibilidade de evitar interrupções na produção se o operador dependesse de sua tarefa realizada, para em conjunto com as demais determinar o salário hora. De alguma maneira imaginava-se pouco sobre interrupções que possivelmente seriam involuntárias e reforçava-se a idéia de que os operadores eram movidos por seus interesses financeiros, estando ansiosos para manter as paradas em nível mínimo. O sistema era complicado, mas procurava manter a lógica de que o ganho seria aumentado conforme o resultado total.

Nesse ponto é importante observar que os técnicos que organizaram tal sistema basearam-se em suposições sobre comportamento de operários ou sobre o comportamento de operários numa grande fábrica americana e imaginaram que cada operário buscaria seu interesse econômico, tentando não só aumentar o seu ritmo de trabalho, mas também o ritmo de outros membros do grupo e como o grupo agiria no sentido contrário da indolência. Esperava-se que um empregado que comprometesse o grupo fosse pressionado para que ele trabalhasse mais arduamente e essa seria a forma pela qual o plano de incentivos deveria funcionar. A questão então seria verificar como isso ocorria na prática. Os operadores desconfiaram do observador, mas se acostumaram a ele, que não representava ameaças. Conversavam livremente sobre o que faziam mesmo que suas opiniões não estivessem estritamente de acordo com o que a empresa esperava e se calavam quando o supervisor ou seu assistente entrava na sala. Os resultados obtidos da observação eram muito semelhantes com aqueles coletados anteriormente nas entrevistas. Era considerada normal na sala de provas, pelos empregados, a montagem de dois equipamentos como a base para cumprimento da tarefa diária e a maior parte do trabalho era realizada pela manhã. Logo que terminavam o que consideravam o bastante para um dia de trabalho, reduziam o ritmo e a curva de produção tendia a se conservar inalterada através das semanas. Há registros de mais dois estratagemas adotados pelos operários, relatórios de produção que não traduziam o que tinham produzido e 
reclamações para concessões sobre o trabalho diário, que na verdade não haviam cumprido. $\mathrm{O}$ observador verificava no término do expediente que muitas vezes o número de aparelhos montados e declarados ao supervisor (o que não era feito pelos supervisores) era diferente do real. A teoria do empregado era de que a produção em excesso deveria ser guardada para um outro dia com déficit. Outra maneira de manter inalterada a produção consistia em pedir pagamento por excesso de trabalho para o dia de trabalho. Desses estratagemas surgiram dois resultados: primeiro os registros de eficiência não representavam o espelho fiel do que era real e as decisões sobre classificação dos empregados continham erros; segundo é que o supervisor era colocado em situação embaraçosa.

Nesse sentido fizeram testes de inteligência e de habilidades, mas não chegaram a uma correlação entre a produção e a habilidade manual ou inteligência. O plano de incentivos não funcionava conforme o desejado. Quando a questão apresentada foi o que não estava dando resultado, o observador declarou novamente sobre uma organização social informal revelada por forte amizade de alguns membros. O importante era verificar não o que dividia esses homens, mas o que eles tinham em comum. Sabia-se que o grupo tinha estabelecido métodos para manter o respeito por suas atitudes e o grupo fazia pressão não sobre os operários lentos, mas sobre os mais rápidos, exatamente aqueles que contribuiriam com a maior parte dos ganhos do grupo. Havia um supervisor encarregado dos operários do grupo, de verificar o trabalho, de agir de acordo com padrões estabelecidos e de repreender por má execução do trabalho. Ele deveria pôr o superior a par de fatos importantes e o comportamento das pessoas o colocava em situações embaraçosas, pois conhecia as artimanhas, conhecia as dificuldades, mas era um representante da administração, deveria defender os interesses maiores da organização e, no entanto, não tinha tempo para duvidar das pessoas e estudar suas reclamações, o que provocaria mais hostilidade.

Segundo alguns teóricos esses supervisores temiam perder a simpatia de seus homens e tornar suas funções mais difíceis. Como o contato com os empregados era permanente esses supervisores registravam suas queixas e as transmitiam sem investigações, pois aparentemente a idéia era ter o registro para se defender em caso de complicações. O motivo alegado para as reclamações, quanto aos defeitos, era principalmente atribuído à matéria-prima e a mão de obra se mantinha como elemento substancial, não sofrendo qualquer redução de salário.

Esse experimento fez com que os investigadores concluíssem sobre um conflito entre organização social (Prática) e técnica da fábrica (Teórico). Os empregados eram pagos de acordo com os planos de pagamentos em grupo, mas os grupos não se comportavam como se 
esperava que se comportassem. A administração introduzia melhorias mecânicas, instituía modificações para reduzir custos ou melhorar a qualidade do produto e, conseqüentemente, estava procurando novos métodos para aumentar a eficiência, quer no projeto de uma nova máquina, quer na instituição de um novo sistema de controle ou na adoção de um novo sistema de organização. Para alguns, essas modificações tinham como objetivo forçar o empregado a trabalhar mais por menos dinheiro e, para outros essas modificações representavam melhoria nas condições de trabalho e possibilidade de maior ganho para o empregado. Essas medidas foram introduzidas por administradores e a ordem era transmitida linha abaixo para que as ações apropriadas acontecessem em cada nível. Então, na investigação, a organização técnica da fábrica referia-se ao que acontecia com a ordem ditada pela alta administração e como ela chegava ao homem que fazia o trabalho manual.

Fizeram a seguinte observação: o operário estava na base de uma organização altamente estratificada e estava sempre na posição de ter que se acomodar às modificações. Embora participasse pouco da organização técnica, ele suportava o maior peso das atividades dessa organização, pois era afetado o tempo todo pelas decisões da administração, não compartilhava suas preocupações com a administração que pouco fazia com o que ele considerava importante ou com o que estava sendo tratado pela cúpula. Há, portanto, uma falha de comunicação extremamente grave, tanto de baixo para cima quanto de cima para baixo. Assim, as pessoas não somente são levadas a se acomodarem às mudanças que se produzem sem a sua participação na decisão, como são afastadas daquelas coisas que dão significado ao seu trabalho.

\subsection{2- Considerações Relevantes sobre a Pesquisa}

A experiência terminou em 1933 e, até o final, a produção do grupo atingiu altíssimo nível de rendimento. Esse nível só foi prejudicado pelo desânimo causado pela profunda depressão econômica que precedeu o fim da prova. A conclusão dos investigadores na época é que não havia correlação entre produção e condições de trabalho, pois mesmo em condições aparentemente desconfortáveis na condição física do ambiente, não se alterava o rendimento do trabalho.

O problema então, persistia: com quais fatores, se é que na realidade existissem, poderiam as modificações no ritmo de produção na sala de provas estarem correlacionadas? As declarações das moças ajudaram a esclarecer que, primeiro elas gostavam do trabalho na 
sala e achavam-no divertido e segundo que com a supressão do antigo controle de supervisão tinham a possibilidade de trabalhar com mais liberdade e sem ansiedade. No grupo havia muita conversa e a conversa ocupava lugar de destaque nos relatórios. Um dos relatores, Whitehead, chamou a atenção para o fato de que as moças eram muito mais rigorosamente vigiadas do que no departamento e o observador era exclusivo. As moças consideravam que a experiência era importante e interessante e que seus esforços deveriam produzir resultados que conduziriam a melhorias gerais de condições de trabalho para suas colegas. $\mathrm{O}$ pesquisador salientou que as mudanças tinham um significado social, pois elas eram ouvidas e convidadas e autorizadas a examinar e vetar projetos de modificações na pesquisa.

Outro fator importante foi o desenvolvimento social do grupo, com troca de presentes nos aniversários e cuidados com alguma moça que se sentia cansada, cuidando cada uma de acelerar o ritmo de trabalho para compensar a baixa produção da companheira. Por último o grupo desenvolveu liderança e objetivo comum de aumentar continuamente o ritmo de produção. Durante muito tempo elas sentiam que podiam atingir o impossível. Em resumo: o aumento de produção não pôde ser relacionado com qualquer mudança experimental das condições físicas de trabalho. Esse aumento pôde ser apontado como conseqüência direta do desenvolvimento de um grupo socialmente organizado, que marchava dentro de peculiar e eficaz sincronização com os supervisores.

Diz o relatório da companhia de janeiro de 1931, referindo-se a todas as pesquisas feitas até aquela data: "Submetendo-se a experiência à análise", somente um elemento pareceu mostrar contínua relação com os progressos no ritmo de produção: a atitude mental dos operários. Pelas conversas que elas mantinham entre si e pelos comentários que faziam aos observadores durante as provas, percebera-se com muita clareza que gradativamente se tornavam mais e mais positivas em suas atitudes: isso demonstrava que no campo de reações e sentimentos de operários, haveria um vasto campo aberto à pesquisa.

Os investigadores voltaram-se para o departamento do qual as moças tinham vindo, que elas comparavam desfavoravelmente com a sala de provas. $\mathrm{Na}$ sala de provas elas encontraram solução para muitos problemas, particularmente de supervisão, que consideravam menos constrangedoras. No departamento consideravam mais humilhante o modo como eram vigiadas, embora a direção julgasse como bons os seus supervisores. A percepção desses pequenos problemas demonstrou que a companhia sabia pouquíssimo sobre fatores determinantes de atitudes das operárias em relação ao equipamento de trabalho, à 
supervisão e à própria empresa. Assim essa fase da pesquisa, denominada "Programa de Entrevista", fixava-se no estudo das relações humanas.

Dessa vez foram reunidos os supervisores do setor de inspeção, esses conheceram os pontos do projeto e passaram a fazer entrevista e observações com funcionários, que não os seus, e que permaneceriam dando informações sem se identificar. As entrevistas no setor de inspeção começaram em setembro de 1928, um ano e meio depois da experiência na sala de "Provas de Montagem de Relés". Os resultados pareciam animadores e o programa fora ampliado para o setor de produção em fevereiro de 1929 para uma divisão de pesquisas industriais, cujas principais funções eram:

- Entrevistar anualmente todos os empregados, verificando opiniões sobre o que agradava ou não na condição de empregado;

- Estudar esses comentários favoráveis e desfavoráveis;

- Eliminar causas dos comentários desfavoráveis;

- Determinar eventuais efeitos positivos dos comentários favoráveis para a companhia e procurar meios e recursos de aproveitar esses benefícios;

- Promover conferências sobre treinamento de supervisão para todos supervisores, tendo como base as entrevistas com os empregados e

- Promover pesquisas referentes às relações com empregados, fadiga e eficiência.

O programa fora considerado ambicioso, pois pretendia abranger 40.000 pessoas e o sistema de entrevistas levava uma hora e meia. Assim de 1928 a 1930 foram entrevistadas apenas 21.126 pessoas, sendo metade do Setor Operacional e as outras de diversas seções.

Aumentaram o número de entrevistadores, que foram escolhidos dentre pessoas dos setores que passaram por entrevistas. Esses novos entrevistadores foram recrutados entre supervisores que eram afastados das funções normais e poderiam, na visão dos pesquisadores, trazer bons resultados. Havia também um grupo permanente de pesquisadores que tinha a missão de treinar os novos operários e encarregar-se da parte técnica do programa e do material das entrevistas. 
Desde o começo, os resultados obtidos no programa foram interessantes. Os comentários mais freqüentes eram: "Isso foi a melhor coisa que a companhia já fez"; ou: "A companhia deveria ter pensado nisso há muito mais tempo". Os empregados davam mostras do agrado que lhe causava o fato de poderem expressar seus pensamentos e sentiam uma espécie de alívio, o que levava à conclusão de que pensamentos longamente represados tivessem afinal encontrado uma válvula de escape.

Alguns supervisores ofereciam-se para participar do plano, pois todos achavam que este devia ser ampliado. Verificou-se que as entrevistas, não só davam vazão às atitudes, mas também modificavam as atitudes. O relatório de 1931 explicou esse resultado inesperado: "Desde muito se sabe que aquele que escreve um memorando esclarece seu próprio pensamento sobre o assunto que pretende apresentar. Exageros, deformações, reações emocionais, defesas etc. são amplamente dissipados quando encarados com objetividade. Assim também os empregados, que ao expressarem seus pensamentos e sentimentos a um ouvinte crítico, descarregam elementos irracionais e emocionais de suas mentes. Muitos problemas de atitudes individuais e pessoais são resolvidos pela expressão verbal que a entrevista permite. Levando-se em conta as expressões de pensamento dos empregados em vinte mil entrevistados, sentimos que o seu valor não pode ser menosprezado".

Nesse ponto já se observava que para o estabelecimento de boas relações industriais, pouca diferença fazia as medidas sobre condições de trabalho e o importante é que os operários chegassem a entender os objetivos dessas medidas. Seria necessário que os operários sentissem que a administração estava interessada no seu bem-estar. No programa de entrevista, a descoberta de que a administração estava interessada no que os operários pensavam e sentiam fora um grande estímulo para todos. A pesquisa tinha o mérito de reforçar um tratamento adequado e inteligente dado aos empregados da Western Electric.

\subsection{3- Observações sobre a Ação dos Supervisores}

O efeito do programa de entrevistas sobre supervisores não foi menos interessante. A administração da empresa achou que a supervisão melhorou quase simultaneamente com o início das entrevistas. Essa melhoria não foi interpretada como um receio por parte dos supervisores de que seus métodos de trabalho fossem considerados ultrapassados ou falhos.

Eles não tinham esse receio porque eles também estavam sendo valorizados com o enriquecimento de seu trabalho. A melhoria do nível de supervisores era resultado do 
aumento de conhecimento dos supervisores sobre os interesses dos operários e também como conseqüência do aumento de interesse nos métodos de supervisão, que surgiu ao se saber que o estudo desses métodos era um dos objetivos da pesquisa. Os apontamentos dos entrevistadores foram usados como material ilustrativo e de debates no treinamento de supervisores. Foi feito um esforço para que o maior número possível de supervisores pudesse ter, antes de assumir o cargo, experiência prévia como entrevistador. Verificou-se com aqueles que já tinham tomado parte nas entrevistas, que eles sentiam que adquiriram nova compreensão dos problemas humanos na empresa e perceberam o que nos pareceu o mais importante - eles começaram a se conhecer melhor.

Enfatiza-se nesse trabalho de tese que dois fatores surgiram como algo inseparável, desde o Experimento de Hawthorne, em estudos futuros para questões que envolvam o comportamento humano: está provado que o homem tem a capacidade de analisar seu semelhante na mesma proporção que seja capaz de se auto-analisar e ainda, aqueles que estiveram ligados ao programa sentiram um entusiasmo natural e espontâneo pelo trabalho, pois manifestavam a crença de que estavam adquirindo novas compreensões, alargando seus horizontes e encarando os fatos com maior objetividade.

Quanto a dados documentando a metodologia adotada verificou-se que os entrevistadores procuravam respostas e para tanto deveriam perguntar sobre condições de trabalho, emprego, supervisão etc, conduzindo o roteiro no sentido desejado através de conversa, apesar das perguntas já formuladas. Algumas respostas dadas eram anotadas resumidamente e consideradas insuficientes. As perguntas que produziram respostas caracterizadas por emissão de opinião eram consideradas, mas com valor diferenciado das demais. Comentários sobre os fatos físicos eram considerados precisos e de fácil investigação. Verificaram que, quando havia perguntas sobre assuntos específicos, essas pessoas, involuntariamente, saiam do assunto e qualquer que fosse a questão procuravam falar sobre o que era de seu interesse. Concluíram que havia necessidade de modificar o método de anotações das entrevistas, adotaram a reprodução "ao pé da letra" e cada relatório passou de, em média, duas páginas e meia para dez páginas. Reduziram o número de pessoas entrevistadas por problemas de custo de cada entrevista.

Como a maioria das perguntas parecia ser de pouca importância para o entrevistado, suas respostas eram, na melhor das hipóteses, superficiais. Mayo e seus parceiros relataram: “tornou-se evidente para entrevistadores os que qualquer que fosse a pergunta, os comentários tendiam a girar em torno de condições ou assuntos específicos, que certos assuntos 
predominavam na mente dos empregados, obscurecendo e tornando irrelevante o todo e inutilizando qualquer tentativa no sentido de desviá-los de suas preocupações. Os entrevistadores notaram que certas pessoas, particularmente silenciosas, podiam sair de seu mutismo e tornarem-se bastante comunicativas quanto a um determinado assunto mencionado na conversa". Considerando que essas observações foram extraídas de uma série de entrevistas, surgiram algumas dúvidas na mente dos pesquisadores quanto à postura dos entrevistadores:

- Haveria alguma razão para que eles tentassem, (como haviam feito), dirigir o empregado para a questão que tinham em mente?

- Por que deveriam ser tratados os assuntos que eram considerados como importantes para entrevistadores e não ao contrário?

- Seria certo negligenciar, como aberração mental, a preocupação do empregado por determinado assunto ou seria mais lógico explorar essas preocupações?

É claro que essas pesquisas, na Western Electric, estavam inter-relacionadas e haviam certas hipóteses que os investigadores queriam provar. A pesquisa na sala de provas revelou que a empresa sabia pouco sobre condições físicas do trabalho e reação dos empregados e sobre adequação ou não dos métodos de supervisão.

As entrevistas, cujo objetivo era esclarecer melhor esse assuntos, também foram decepcionantes na expectativa dos estudiosos, pois os comentários eram de aplicação restrita para os objetivos, mas apresentavam reflexo das crenças, suposições e aspirações inconscientes do pessoal entrevistado. Nesse ponto fica claro que os investigadores procuravam explicar o comportamento das pessoas e que as informações colhidas nas entrevistas não podiam ser consideradas reações dos seres humanos, mas de indivíduos em interação e surgiu o interesse pela organização social dos empregados e pela situação do trabalho. Essa nova análise levara a um desinteresse pelas entrevistas individuais, abandonando-se as experiências das salas de provas e mudando-se o sentido inicial da pesquisa, passaram a estudar as relações sociais entre pessoas no ambiente de trabalho. 


\subsection{4- O Experimento e as Considerações Relevantes para a Tese}

Ao longo das entrevistas os estudiosos já haviam verificado um tipo de comportamento que indicava que os operários se organizavam informalmente para se protegerem de práticas que consideravam uma ameaça ao seu bem-estar. É consenso no relato que os pesquisadores identificaram nesses comportamentos a capacidade dos empregados de estabelecerem padrões de produção controlada, algum tipo de punição aos sabotadores, desagrado com sistema de pagamento por produção em grupo, preocupação com promoções, contentamentos e descontentamentos com relação a superiores imediatos.

Os relatores Roethlisberger e Dickson resumem os resultados do estudo intensivo desse grupo de empregados assim: "De acordo com nossa análise, a uniformidade de comportamento manifestada pelo grupo foi o resultado de uma disparidade entre as modificações possíveis na organização técnica, de um lado e na organização social de outro. Quanto aos sentimentos sociais e os costumes de trabalho dos operários que não se acomodaram às rápidas inovações técnicas ali introduzidas, o resultado foi o aparecimento de uma cega resistência a qualquer inovação e a formação de uma organização social que se opunha à organização técnica".

Sobre o resultado das pesquisas, segundo Stuart Chase, "em se solicitando o auxílio e a cooperação das moças para o experimento", os pesquisadores fizeram com que elas se sentissem importantes, pois deixaram de se sentirem como peças de uma máquina para se colocarem na posição de um grupo coeso que tentava ajudar a companhia a resolver um problema. Elas encontraram estabilidade, um grupo ao qual sentiam pertencer e, um trabalho cujo objetivo podiam claramente perceber, logo trabalharam mais e melhor do que em qualquer época de suas vidas.

O grupo de pesquisadores passou vários anos pesquisando o trabalho humano na fábrica de Hawthorne e trouxeram elementos para que se concluísse que o operário não era simples peça de processo, mas sim um indivíduo com personalidade complexa e que quando ele está relacionando-se com os demais numa situação de grupo, pode estar motivado não só pela busca de conforto material, mas também por necessidades de natureza social e psicológica, portanto interage em grupo e a situação grupal também se torna complexa e difícil de compreender.

Pôde-se aprender com as conclusões do experimento e sobre contexto organizacional e as pessoas, que esse homem da modernidade industrial, muito distante do trabalhador e do 
artesão, desenvolvera maneiras próprias de realizar seu trabalho e habilidades próprias e satisfações próprias que revelavam seus padrões de realização, conforme sua época. Por um outro lado não desenvolvia seu trabalho como ser isolado, mas sempre como membro de um grupo unido pela cooperação e, como hoje, pela troca de informações e possibilidades de aprendizagem.

Quando Mayo passou a interessar-se pelos problemas provocados pela civilização industrial americana, ele contribuiu para desenvolver, em parte, a visão que se tinha do homem nas empresas. A partir dos estudos de Hawthorne os empregados passaram a ter sentimentos e valores: a fábrica era um sistema social em equilíbrio e devia-se prestar muita atenção nele. Mayo enfatizou que o futuro da civilização dependeria de gestores dotados de sólido saber sociológico. Para ele, era no meio industrial que se podia recriar a solidariedade perdida pela desigualdade. Trata-se de uma visão funcionalista, que encontra respaldo nos conceitos introduzidos pela teoria de Émile Durkheim, sobre solidariedade social e que distingue duas grandes concepções históricas: a da solidariedade mecânica, típica das sociedades primitivas, que se caracteriza por forte ligação entre o indivíduo e o grupo ao qual pertence, e a da solidariedade orgânica, típica da sociedade industrializada - geradora de grande desigualdade social. Nesse sentido a socialização do indivíduo, por meio das instituições sociais, traz no seu bojo a bússola para guiar o indivíduo em sociedade; as regras e normas são necessárias para o equilíbrio social e a noção de direitos e deveres legitima o uso das punições como forma de equilíbrio. Mayo trouxe uma parcela de igualdade à Sociologia Industrial Americana que foi incorporada ao universo do gerenciamento, a partir da Experiência de Hawthorne.

Se a preocupação inicial de Mayo esteve condicionada às exigências de eficácia no trabalho, ao longo da pesquisa deslocou-se para questões de coesão e de cooperação. Uma das conclusões mais importantes das pesquisas na Western Electric aparece como uma ameaça à organização e deveria ser controlada a existência de grupos que estariam continuamente se formando entre os operários industriais e que criavam códigos e relações de lealdade entre seus membros, independentemente do contexto e regras. Embora esses códigos pudessem ser destruídos, a pesquisa revelou que esses não surgiram senão como produtos de interação contínua entre os membros do grupo, portanto eles podem ser reconstruídos. Em gestão nos dias de hoje essa interação, longe de ocorrer pela rotina do trabalho, ocorre pela necessidade de interagir com novos conhecimentos, de compartilhamento de informações, de intermediação de novas tecnologias e atendimento aos clientes e acionistas. 
Para Mayo Apud Davis e Newstrom (2002), os problemas humanos tornaram-se um amplo campo de estudo e uma oportunidade para o progresso social. Mayo é reconhecido como "pai" daquilo que era chamado de relações humanas, que mais tarde passou a ser investigada sob a ótica do comportamento organizacional, envolvendo falta de habilidade de comunicação dos chefes, falta de motivação dos funcionários, conflitos entre os membros das equipes e necessidade de superar a resistência dos trabalhadores no que se refere aos interesses organizacionais e assuntos similares.

O estudo do comportamento organizacional se preocupou com a questão da satisfação no trabalho que consiste em uma atitude e mudanças na organização, que podem propiciar a satisfação. A organização é vista como uma unidade social conscientemente coordenada, composta por pessoas, que funciona de maneira relativamente contínua, com intuito de atingir um objetivo comum. As pessoas devem aprender sobre as ações no trabalho visando melhores resultados. Para Robbins (2004), a disciplina de comportamento organizacional refere-se ao estudo sistemático das ações e das atitudes das pessoas dentro das organizações, que alteram o processo produtivo e, mais recentemente a cidadania organizacional é um comportamento discricionário que não faz parte das exigências funcionais, mas que ajuda a promover o funcionário eficaz na organização.

Respeitando-se uma linha de evolução do pensamento administrativo, entende-se que com Taylor, os problemas humanos dificultavam a produção e dessa forma deveriam ser minimizados, talvez essa continue sendo a idéia de comportamento organizacional que, em última instância também visa o controle do comportamento para não interferir no resultado. A pesquisa de Taylor aumentou a produção com racionalização do trabalho, mas com Mayo é que veio a concepção de que seria possível aumentar a produção humanizando-a.

A pesquisa de Mayo foi duramente criticada como sendo inadequadamente controlada e interpretada, mas suas idéias, tal como o sistema social dentro do ambiente de trabalho, permanece desafiando o tempo, nas disciplinas de gestão, de comunicação e de comportamento das pessoas. O que se entende é que nas décadas de 1940 e 1945 muitos outros projetos de pesquisas foram desenvolvidos incluindo dinâmica de grupo, liderança e motivação, o que favoreceu a "idade das relações humanas", estimulando novos interesses quanto ao comportamento das pessoas no trabalho para uma boa organização do trabalho. Portanto o "todo" ajudou a emergir os valores humanos em paralelo com os demais valores no trabalho, e contribuiu também para uma nova problemática na gestão de pessoas, na análise do trabalho distinta da ação no trabalho. 


\section{3- Abordagem Comportamental da Administração e o Lado Humano na Empresa}

Uma nova configuração passa a dominar a teoria administrativa a partir dos trabalhos de dinâmica de grupo, desenvolvidos por Kurt Lewin, ainda na sua fase de impulsionador da Teoria das Relações Humanas, com a divulgação do livro de Chester Barnard (The Functions of the Executive) e, posteriormente, dos estudos de George Homans sobre sociologia funcional de grupo (The Human Group), culminando com a publicação do livro de Herbert Simon (Administrative Behavior), sobre o comportamento administrativo. Desenvolveu-se a partir da década de 1950, inicialmente nos Estados Unidos, uma nova concepção de administração, trazendo novos conceitos, novas variáveis e, sobretudo, uma nova visão da teoria administrativa baseada no comportamento humano nas organizações.

A abordagem comportamental marcou a mais forte ênfase das ciências do comportamento na teoria administrativa e a busca de soluções democráticas e flexíveis para os problemas organizacionais. Esta abordagem originou-se das ciências comportamentais e, mais especificamente, da psicologia organizacional. É com a abordagem comportamental que a preocupação com a estrutura se desloca para a preocupação com os processos e com a dinâmica organizacional, isto é, com o comportamento organizacional. Aqui ainda predomina a ênfase nas pessoas, inaugurada com a Teoria das Relações Humanas, mas dentro de um contexto organizacional.

\subsection{1- Teoria Comportamental da Administração}

A Teoria Comportamental (ou Teoria Behaviorista) da Administração veio significar uma nova direção e um novo enfoque dentro da teoria administrativa: a abordagem das ciências do comportamento, o abandono das posições normativas e prescritivas das teorias anteriores e a adoção de posições explicativas e descritivas. A ênfase permanece nas pessoas, mas dentro de um contexto organizacional. Principais vultos da teoria: Kurt Lewin (18901947), Douglas McGregor, Herbert Simon, Rensis Likert, Chris Argyris, J.G.March.

O movimento behaviorista surgiu como evolução de uma dissidência da Escola das Relações Humanas, que recusava a concepção de que a satisfação do trabalhador gerava de forma intrínseca a eficiência do trabalho. A percepção de que nem sempre os funcionários seguem comportamentos exclusivamente racionais ou essencialmente baseados em sua satisfação exigia a elaboração de uma nova teoria administrativa. A Teoria Comportamental defendia a valorização do trabalhador em qualquer empreendimento baseado na cooperação, 
buscando um novo padrão de teoria e pesquisa administrativas. Foi bastante influenciado pelo desenvolvimento de estudos comportamentais em vários campos da ciência, como a antropologia, a psicologia e a sociologia. Adotando e adaptando para a administração conceitos originalmente elaborados dentro dessas ciências, propunha-se fornecer uma visão mais ampla do que motiva as pessoas para agirem ou se comportarem do modo que o fazem, particularizando as situações específicas do indivíduo no trabalho. Dentre os trabalhos fundamentais para a eclosão do behaviorismo destacam-se os de Barnard, acerca da cooperação na organização formal e os de Simon, relativos à participação dos grupos no processo decisório da organização. Eles oferecem os principais pontos de referência para a formulação das propostas iniciais dessa abordagem. Posteriormente, essas idéias e propostas foram complementadas pela Teoria X e Y de McGregor, pelo Sistema 4 de Rensis Likert, pelas teorias motivacionais de Herzberg e de McClelland, assim como pelos estudos de Chris Argyris.

A Teoria Comportamental procura demonstrar a variedade de estilos de administração que estão à disposição do administrador. A administração das organizações em geral está fortemente condicionada pelos estilos com que os administradores dirigem, dentro delas, o comportamento das pessoas. Por sua vez, os estilos de administração dependem substancialmente das convicções que os administradores têm a respeito do comportamento dentro da organização. Essas convicções moldam não apenas a maneira de conduzir as pessoas, mas também a maneira pela qual se divide o trabalho, planejam e organizam as atividades.

\subsection{2- Teoria X, Teoria Y e Teoria Z}

McGregor, um dos mais famosos autores behavioristas da Administração, preocupouse em comparar dois estilos de administração a partir dos opostos e antagônicos da administração: de um lado, um estilo baseado na teoria tradicional, excessivamente mecanicista e pragmática, a que deu nome de Teoria $\mathrm{X}$ e de outro, um estilo baseado nas concepções modernas a respeito do comportamento humano, denominada de Teoria Y.

\section{Teoria X}

É a concepção tradicional de administração e se baseia em convicções errôneas e incorretas sobre o comportamento humano, como, por exemplo: $\mathrm{O}$ homem é indolente e 
preguiçoso por natureza, ele evita o trabalho, falta-lhe ambição, não gosta de assumir responsabilidades. O homem é egocêntrico. A sua própria natureza o leva a resistir às mudanças. A sua dependência o torna incapaz de autocontrole e autodisciplina.

Em função dessas concepções e premissas a respeito da natureza humana, a Teoria X reflete um estilo de administração duro, rígido e autocrático e que se limita a fazer as pessoas trabalharem dentro de certos esquemas e padrões previamente planejados. Toda vez que um administrador impõe arbitrariamente e de cima para baixo um esquema de trabalho e passa a controlar externamente o comportamento de trabalho de seus subordinados, ele estará aplicando a Teoria X. O fato de ele impor de forma autocrática ou impor suavemente não faz diferença, segundo McGregor. A teoria X se fundamenta em uma série de pressuposições errôneas acerca do comportamento humano e apregoa um estilo de administração onde a fiscalização e o controle externo rígido, constituem mecanismos para neutralizar a desconfiança da empresa quanto às pessoas que nela trabalham. Segundo esta teoria o único estímulo para o trabalho é o salário e se o estímulo salarial não vem, o trabalho não sai.

\section{Teoria Y}

É a moderna concepção de administração, de acordo com a teoria comportamental. A teoria Y se baseia em concepções e premissas atuais e sem preconceitos a respeito da natureza humana. A Teoria Y desenvolve um estilo de administração muito aberto e dinâmico, extremamente democrático, através do qual administrar é um processo de criar oportunidades, liberar potencialidades, remover obstáculos, encorajar o crescimento individual e proporcionar orientação quanto a objetivos. Está totalmente oposta à teoria X. São pressupostos da Teoria Y, que as pessoas são esforçadas e gostam de ter o que fazer, o trabalho é uma atividade tão natural como brincar ou descansar; procuram e aceitam responsabilidades e desafios; podem ser automotivadas e autodirigidas e são criativas e competentes.

\section{Teoria Z}

A teoria administrativa tem sido permeada de modismos nas últimas décadas como APO - Administração por Objetivos ou CCQ- Círculo de Controle de Qualidade, Teorias X e Y, Enriquecimento de Cargos, Desenvolvimento Organizacional etc., que constituíram novidades e que permanecem ao longo dos tempos. Antes de morrer, McGregor estava 
escrevendo a Teoria Z, que havia surgido da necessidade de sintetizar os rumos organizacionais e pessoais. O conceito dessa teoria foi aproveitado por William Ouchi, que analisou os métodos de trabalho japonês e desenvolveu muitas idéias de McGregor. No início da década de 1980, surgiu a Teoria Z, que se fundamenta nos seguintes princípios:

1- Emprego estável para as pessoas, mesmo em época de dificuldades para a organização;

2- Pouca especialização das pessoas e necessidade de desenvolvimento com a filosofia de treinamento para o exercício dos cargos;

3- Avaliação do desempenho constante e promoção lenta;

4- Igualitarismo no tratamento das pessoas, não importando o seu nível hierárquico. Todas as pessoas passam a ter igual tratamento, iguais condições de trabalho, iguais benefícios etc.;

5- Democracia e participação: todas as pessoas participam em equipe e nenhuma decisão é tomada sem o consenso do grupo e

6- Valorização das pessoas, a tal ponto que o maior patrimônio das empresas japonesas, são as pessoas que nela trabalham.

A Teoria $\mathrm{Z}$ proporciona a base para todo programa de administração orientado para os recursos humanos da empresa: todas as decisões organizacionais devem ser tomadas através do consenso, com ampla participação das pessoas e orientadas para longo prazo. A Teoria Z é um modelo de administração participativa.

\subsection{3- Repercussões das proposições sobre a Motivação Humana}

Para explicar o comportamento organizacional, a Teoria Comportamental se fundamentou no comportamento individual das pessoas. Para poder explicar como as pessoas se comportam, torna-se necessário o estudo da motivação humana. Os autores behavioristas verificaram que o administrador precisava conhecer as necessidades humanas para melhor compreender o comportamento humano e utilizar a motivação humana como poderoso meio para melhorar a qualidade de vida dentro das organizações.

Ao longo de um século parece-nos que a indústria desenvolveu conhecimentos para utilizar as ciências exatas e a tecnologia em benefício material, porém ainda precisa aprender 
com as ciências humanas para fazer com que as organizações humanas se tornem realmente eficientes. O desenvolvimento das escolas comportamentalistas e a introdução de conceitos como motivação e liderança visaram uma sinalização do comportamento esperado da parte dos funcionários, da legitimação do poder dos níveis superiores e da satisfação no trabalho, condicionada às regras impostas pela organização. Acredita-se que, em condições apropriadas dentro das organizações, a energia criadora do homem deve ocupar espaço relevante.

Ao se examinar a questão da motivação como um problema a ser controlado pela administração, verifica-se que a teoria da motivação de Maslow, objetivando a esperança contínua e da satisfação parcial das necessidades humanas funciona bem em certas circunstâncias. Os meios para satisfação das necessidades fisiológicas e de segurança do homem podem ser proporcionados ou negados pela administração. O próprio emprego é um desses meios, assim como o salário, as condições de trabalho e os benefícios concedidos. Assim a administração pode controlar o indivíduo enquanto ele estiver lutando pela subsistência.

Numa situação em que o homem alcança nível adequado de subsistência e ele está motivado por necessidades de nível alto essa teoria não funciona, pois a administração não pode dotar um homem de auto-respeito, fazer com que ele seja admirado pelos companheiros ou satisfazer suas necessidades de auto-realização. A administração pode criar condições para que ele se sinta encorajado e seja capaz de procurar por si só tais satisfações.

Por outro lado, a administração pode impedir que alguém alcance tais satisfações, não proporcionando essas condições. A administração encontra-se numa difícil posição, o padrão de vida criado pela tecnologia proporciona adequada satisfação das necessidades fisiológicas e de segurança.

Focando na possível satisfação de necessidades de nível mais baixo, a administração privou-se da possibilidade de usar como motivadores os procedimentos nos quais a teoria convencional se apóia: recompensas, promessas, incentivos, ameaças e coerção. Como repercussão das proposições sobre a Motivação Humana, uma filosofia de administração por controle tornou-se inadequada, na medida em que a motivação das pessoas possa estar centrada em necessidades sociais e do próprio ego.

Entende-se que quando as pessoas são privadas da oportunidade de satisfazer no trabalho as necessidades que lhe parecem importantes, as pessoas se comportam como o previsto pela Teoria X: com indolência, passividade, resistência às mudanças, falta de 
responsabilidade, inclinação em acreditar na demagogia e na solicitação excessiva de benefícios econômicos. As condições impostas pela teoria clássica de organização e pela administração científica "amarraram” o homem a empregos limitados e não especializados, nos quais pouco era exigido para utilização de sua capacidade, o que desencorajava a aceitação de responsabilidade, encorajava a passividade e numa visão de senso comum, eliminou do trabalho a sua significação maior.

Assim, hábitos, atitudes e expectativas do homem - todo o seu conceito de participação - têm sido condicionados por experiências nessas circunstâncias. Ao longo da história da administração das empresas as pessoas foram acostumadas a serem dirigidas, manipuladas e controladas e ensinaram-lhes a encontrar fora do trabalho satisfação para suas necessidades sociais, de auto-estima e de auto-realização.

\subsection{4- Revisitando McGregor e Revelando o Lado Humano}

Sobre as ciências humanas é necessário lembrar o princípio básico do que seja a Lei de Causa e Efeito. Por esta Lei nada acontece ao acaso, portanto, indica que para toda causa existente haverá um efeito. E ainda pelo princípio hermético de Causa e Efeito, não se pode imaginar nada fora de um todo que esteja fora da Lei. A lei em funcionamento determina que todo Efeito tem a sua Causa.

McGregor investigou sobre como aplicar esse conceito sobre a natureza humana e chamou de Teoria $\mathrm{X}$ o conceito tradicional da tarefa da administração que diz respeito ao controle da energia humana para realização dos objetivos da organização. Esse controle seria justificado a partir de três proposições: cabe à administração a organização de recursos produtivos (dinheiro, materiais, equipamentos, pessoas) para realização de seus fins econômicos; com relação às pessoas, a administração é o processo de dirigir esforços para motivá-las, controlar suas ações e modificar seu comportamento para atender as necessidades da organização; sem essa intervenção da administração as pessoas seriam indiferentes ou hostis às necessidades da organização.

Quando McGregor propôs a teoria Y, visualizou a necessidade de uma nova teoria sobre a tarefa de administrar pessoas e sugeriu que: a administração fosse responsável pela organização dos elementos produtivos da empresa para que ela pudesse atingir seus objetivos econômicos; as pessoas não são resistentes às necessidades da organização por natureza, pois elas podem se tornar assim por sua experiência nessa ou em outras organizações; a motivação, 
o potencial de desenvolvimento e a capacidade de assumir responsabilidades e dirigir o comportamento para os objetivos da organização estão todos presentes nas pessoas.

Esses fatores não são criados nas pessoas pela administração, mas é de responsabilidade da administração proporcionar condições para que as pessoas reconheçam e desenvolvam por si próprias, essas características.

A tarefa essencial da administração é criar condições e métodos de operação em que as pessoas possam atingir melhor seu objetivo, orientando seus esforços em direção aos objetivos da organização. Na sua visão a administração revela-se a partir de um processo de criação de oportunidades, de realização de potenciais, de remoção de obstáculos e de encorajamento ao crescimento.

Sob um olhar mais convencional prevalece a crença de que o homem se dedica ao trabalho o mínimo possível, então se é considerado como um ser indolente ele receberá o tratamento para que isso seja reprimido e controlado pela administração. Paradoxalmente não se aceita dele: a falta de ambição; a ausência de responsabilidade e liderança; o perfil egocêntrico; a indiferença com relação às necessidades e objetivos da empresa; a resistência às mudanças e o desvio para sua atenção para assuntos não pertinentes ao seu trabalho.

Quando se usa comumente a expressão "administrar consiste em conseguir com que as coisas sejam feitas pelas pessoas", desenvolveu-se uma visão de que o gestor deva saber persuadir, recompensar, punir e controlar.

Na visão tradicional da função da administração o lado humano da empresa econômica é moldado pelos administradores a partir dessas crenças, e as estruturas convencionais, as diretrizes, as práticas e programas administrativos das organizações, refletem essas suposições.

Assim a administração se divide num extremo mais coercitivo ou de ameaça, geralmente disfarçada, com o controle rígido das ações, e no outro extremo pode ser mais liberal, buscando satisfação e harmonia, pois se acredita que assim as pessoas serão mais maleáveis e aceitarão melhor o direcionamento necessário a uma organização. Nos dois casos o propósito do método é dirigir o comportamento humano.

Um erro da administração tradicional esteve marcado pela crença de que podia estudar sobre comportamento para aprender sobre a natureza humana e sobre como dirigir esse comportamento. As ciências humanas desviaram seu interesse para a natureza da organização 
industrial, as filosofias, as diretrizes e as práticas da administração em geral. Menos para os humanos.

Durante meio século de mudanças de orientações, a administração aprendeu, na época de pleno emprego, que o uso da força gerava oposição e com ela a restrição da produção, sindicalismo ativo, sabotagem sutil, etc. Acreditava-se que ao ser condescendente com a pessoa, ela procurava se aproveitar desse tipo de administração mais ausente e nesse sentido, seria sábio adotar uma administração firme e justa. Dificilmente se pensaria em um caminho do meio.

Considerando que as idéias de McGregor sobre a Teoria $\mathrm{X}$ apresentavam uma preocupação sobre os efeitos do controle externo do comportamento e que a Teoria $\mathrm{Y}$ baseava-se no autocontrole e na autodireção, ao se utilizar o primeiro método durante décadas, não se poderia esperar que a administração estivesse preparada para aplicar a segunda e lê-se em várias obras de McGregor, estas observações em 1957. Com a teoria Y vieram algumas idéias sobre Descentralização e Delegação, como meio de libertar as pessoas de controle excessivo, dando-lhes grau de liberdade para assumir responsabilidades e satisfazer suas necessidades de auto-estima.

\subsection{5- A Aceitação/Rejeição do Estudo das Relações Humanas}

Anibal Bonfim em 1954 afirmou que a expressão "relações humanas" significava o estabelecimento e/ ou a manutenção de contatos entre seres humanos. Portanto era algo que ocorria diariamente na vida de cada um. Num sentido mais estrito, a expressão relações humanas queria dizer todos aqueles contatos entre seres humanos que se procuram em todas as situações.

Na visão de Drucker (1981: 263), é totalmente impossível administrar o trabalho e o trabalhador se forem enfocados como problemas, por isso a administração deve se concentrar nos aspectos positivos e se fundamentar nos pontos fortes e na harmonia.

A teoria de relações humanas parte de conceitos básicos corretos: as pessoas querem trabalhar e administrá-las é função do administrador, não de um especialista. Não constitui, portanto, apenas um amontoado de atividades desvinculadas umas das outras. Repousa ainda sobre uma profunda percepção que pode ser resumida quando dizemos: 'não se pode contratar um braço, uma pessoa inteira vem junto`. (DRUCKER 1981: 263).

Nesse sentido, para o autor, é importante o reconhecimento da natureza social das pessoas e a necessidade do administrador aprender que além de trabalhar juntas, as pessoas 
vão se relacionar. Não é necessário um especialista para tratar do assunto tão óbvio, pois as pessoas em atividade estão vinculadas umas a outras e ainda, devem ser percebidas como uma pessoa inteira.

Falta às relações humanas uma percepção da dimensão econômica do problema. Como resultado elas tendem a se degenerar em meros slogans que se transformam em álibis para a inexistência de uma política administrativa da organização humana. Mas o que é pior, como as relações humanas começaram da tentativa de ajustar o indivíduo "desajustado" à "realidade" (a qual sempre se presume racional e real), em sua própria concepção existe uma forte tendência à manipulação. E com esta tendência caminha junto $o$ perigo das relações humanas se transformarem num paternalismo freudiano, num mero instrumento para justificar medidas da administração, num dispositivo para a administração "vender" aquilo que está fazendo. (DRUCKER 1981:263).

$\mathrm{O}$ autor ao observar o que falta às relações humanas preocupou-se com um possível enfoque inadequado, por parte da administração que poderia utilizar as relações humanas apenas para manipular as pessoas. Considerou que os estudos de motivações deveriam buscar resultados para a execução do trabalho e da tarefa e que as relações humanas dariam ênfase nas relações interpessoais e no "grupo informal". Então nessa visão o ponto de partida seria o indivíduo e não a análise do trabalho e do trabalhador. Observa-se que Drucker (1981) já havia alertado para um descuido de tomar o tema das relações humanas como um dispositivo para administração, que estava errada ao considerar irrelevante o tipo de trabalho de um indivíduo e preocupar-se apenas com o relacionamento do trabalhador com seus colegas, bem como sua atitude e comportamento visando o alcance da eficácia operacional. Apesar do seu destaque à natureza social das pessoas, as relações humanas não consideram questões como interesses e perspectivas individuais. Nega-se, portanto, uma esfera política e uma espécie de medo da influência que os sindicatos exerciam sobre os indivíduos, na época.

Numa linha evolutiva, o conceito de relações humanas passou a ser considerado como uma atitude que deva prevalecer no estabelecimento de contato entre pessoas. Observa-se que não se trata apenas de estabelecer, mas manter esses contatos. E nessa atitude, estão embutidas questões que são pouco tratadas nas organizações, como o reconhecimento dos princípios da diversidade, o que coloca os seres humanos como possuidores de personalidade própria, capacidades e limitações que não são respeitadas porque não se fala sobre elas. Seguindo essa lógica, praticar relações humanas apresenta uma forte idéia de se ir muito além de estabelecer ou manter contatos, pois requer das pessoas o conhecimento sobre si próprio. Uma atitude implica em uma maneira de ver as coisas que permita a cada um compreender o outro e respeitá-lo a partir do princípio de que a sua responsabilidade é diferente da de cada 
um de nós. Portanto, conhecer a própria personalidade é o início de um parâmetro para se aceitar. Parece ser difícil reconhecer no outro o que não se conhecesse em si mesmo. Assim, em um significado mais amplo, a atitude de relações humanas poderá ou não estar presente no contato entre as pessoas e na ausência da atitude, o resultado é um clima de resistência, incompreensão, falta de comprometimento e pouco aproveitamento positivo das relações que se estabelecem. A prática de relações humanas está embutida no convívio humano e pode avançar com a discussão do conceito de convivencialidade.

Torna-se muito importante verificar que quando um indivíduo tem crédito para sua "fala" isso facilita no desenvolvimento das relações e favorece o processo de aprendizagem. Tomando como base a Experiência de Hawthorne, a questão das relações humanas e do convívio pode ser aplicada à ampliação da visão dos gestores de pessoas. Nas duas experiências realizadas na Western Electric, de acordo com os relatores, verificou-se uma quebra contrastante da visão dos empregados com relação à pesquisa. Na primeira "as moças diziam que se sentiam livres da pressão da supervisão", embora estivessem sob supervisão muito mais estrita do que no departamento. Na segunda, "os homens temiam a supervisão e agiam de maneira a neutralizá-la”, colocando-se em posição de reação às modificações técnicas que consideravam não ter propósito claro. Observou-se que as montadoras de relés tinham conferências periódicas com o superintendente, que lhes dizia que modificações experimentais estavam sendo planejadas e nessa comunicação os pontos de vista delas eram ouvidos. Em muitos casos, elas podiam votar sobre o que estava sendo proposto e acreditavam fazer parte de uma experiência, que elas julgavam interessante e importante.

Ambos os grupos desenvolveram uma organização social informal, mas no segundo caso "os operários" se organizaram para se opor à administração, ao passo que "as montadoras" se organizaram para cooperar com a administração e com um objetivo comum. Aprendeu-se com relação às reações dos dois grupos que um levou à restrição de produção e o outro levou ao aumento constante de produção. Esses contrastes podem trazer muitas contribuições quando o foco é a aprendizagem e a comunicação porque mais do que estimular a participação dos empregados, no grupo das moças houve um sentido de aproximação das pessoas no sentido de engajamento com as mudanças, com a necessidade de aprender para saber agir em situações de mudanças, de dar respostas para o que não é rotineiro e de atingir resultados pessoais. 


\subsection{6- Comunicação para as Mudanças no Lado Humano nas Organizações}

Trazer elementos para uma discussão simples sobre a importância da comunicação para estreitar laços deve ser considerado de alta prioridade para os gestores no desenvolvimento do trabalho. Em uma auto-avaliação o administrador deve incorporar o conceito de comunicação não apenas sob a ótica instrumental, mas também sob o aspecto relacional e ele pode então se ver como "uma causa" para tantas dificuldades em gerir uma empresa com pessoas. Pode parecer primário propor que o gestor reveja conceitos “emprestados" de cursos e livros de "management", mas também é primária a despreocupação em não rever os significados que são atribuídos à comunicação: manter o controle, passar a conversar, "dourar a pílula", "levar no bico" ou por outro lado usar a comunicação para fazer amigos e influenciar pessoas.

Então a questão agora é ir até as causas que possam impedir que os estudos em comunicação tragam elementos para apoiar a administração de recursos humanos no seu papel de gerar condições para o alcance de resultados humanos, cuidando do encaminhamento de temáticas sobre gestão, comunicação e pessoas, em convívio com os paradoxos de um tempo no qual os ensinamentos nem sempre são aprendidos e colocados em prática para gerar transformações.

Quando se trata de gestão com pessoas é necessário perceber o princípio da polaridade para se acreditar que é hora de olhar o reverso da mesma moeda: por um lado controle do comportamento das pessoas e do outro, o estímulo ao desenvolvimento das pessoas.

$\mathrm{Na}$ Experiência de Hawthorne, "as moças" colaboraram no experimento porque entendiam que estavam ajudando a resolver um problema para a companhia e nessa atitude foi relevante o papel dado à comunicação transparente, pois mesmo com a supervisão presente sentiam--se "livres de pressão". Ao participarem das conferências periódicas com o superintendente, as moças tomavam conhecimento sobre modificações experimentais que estavam sendo planejadas e ao serem ouvidas, podiam votar sobre o proposto. Diante da clareza dos fatos deve-se observar que para atitudes dos administradores em relação aos demais membros da organização não houve estímulo para se reconhecer em cada um, mais do que um simples executor de uma dada tarefa, mas também seres humanos. Embora seja algo desejável por alguns administradores, os indivíduos na organização não se comportam de 
maneira única e, exclusivamente, dentro de uma lógica e padrão de expectativa do observador ou daquele que comanda a relação.

Entende-se, portanto que ao longo da história dos modelos de administração prevaleceu o modelo racional do controle da exterioridade e o fator subjetividade ficaria "do lado de fora do portão da fábrica". Administradores aprenderam sobre dificuldades de se lidar com os sentimentos, sensibilidade e emoção das pessoas e na mesma proporção desconsideram que essas são qualidades inerentes a todos os seres humanos.

Para o gestor fica a árdua tarefa de compreender sobre relações humanas e orientar nas relações entre indivíduos e organização no sentido de criar um ponto de apoio a partir de sua própria atitude chamada de relações humanas. À Administração de Recursos Humanos compete rever os parâmetros que vem sendo utilizados para gestão com pessoas considerando-se que as organizações têm seus objetivos e que para alcançá-los são as pessoas que podem contribuir para o processo.

Considerando-se os modelos de gestão de pessoas na Era do Conhecimento, o homem deixou de ser valorizado como "mão de obra" e passou a ser valorizado como "mente de obra", então ele deve cumprir funções que a máquina não pode suprir: conhecer, intuir e criar para atingir resultados e agregar valor ao produto/ serviço oferecido ao cliente. Quando reconhecidas por seus valores e talentos, as pessoas são responsáveis por otimizar resultados, contribuir com seus conhecimentos, gerar melhorias de processos de trabalho e vivenciar a satisfação no trabalho pela valorização de competências desenvolvidas.

Os resultados humanos começam a se revelar quando as pessoas aprendem sobre o desenvolvimento pessoal e profissional, sobre reconhecer a aprendizagem aplicada também a sua condição de ser social, sobre saber o que acontece ao seu redor e de poder conduzir seus próprios passos com uma nova responsabilidade: ter competência para viver no Século XXI.

Para libertar as pessoas do controle excessivo, os teóricos em administração têm pesquisado sobre uma ampliação do campo e da significação do trabalho. Os profissionais de modo geral têm sido encorajados a aceitar responsabilidades com base nas necessidades da organização e na busca pessoal à satisfação de necessidades sociais e de auto-estima.

A Administração Participativa e a Consultiva são exemplos que encorajavam as pessoas a orientar suas energias criativas visando os objetivos da organização, dando-lhes alguma participação nas decisões que as afetavam e proporcionavam oportunidades para 
satisfação de suas necessidades sociais e de auto-estima. Um exemplo construído pela administração para promover o trabalho do indivíduo foi a tradicional Avaliação de Desempenho - AD, que ao ser examinada mais profundamente, como programa de avaliação nos diversos níveis, revelou-se mais condizente com a Teoria $\mathrm{X}$, pois tais programas tendiam a tratar as pessoas como se elas fossem produtos que seriam inspecionados numa linha de montagem.

Algumas empresas aprenderam sobre os próprios empregados, estabelecerem objetivos para eles e instituíram novos métodos de Auto-Avaliação, que evidentemente é um caminho que faz sentido, principalmente, quando os gestores exercem um papel de liderança a ser imitado, pois esse sistema de avaliação exige das pessoas no comando a competência de saber transferir conhecimentos, estimular a auto-realização, o autodesenvolvimento e de saber valorizar as pessoas para que elas possam criar parâmetros para sua própria avaliação.

Hoje algumas empresas adotam a Avaliação $360^{\circ}$, cuja característica maior está em buscar a diversidade de visões das pessoas com as quais um profissional convive e que ele saiba lidar com esse "retorno" sobre sua atuação. Trata-se de um importante instrumental para desenvolvimento profissional e pessoal quando permite ao indivíduo, ao ouvir ou receber um feedback, que o mesmo possa conhecer a visão de outras pessoas sobre seu trabalho; porém observa-se que será fortemente significativo quando o indivíduo tiver interiorizado a idéia de feedback como subsídio para a própria transformação. Para a ação dos gestores os processos de feedback com múltiplas fontes funcionam como instrumento efetivo de aprendizagem e desenvolvimento, conforme Reis (2003:55) "Indivíduos situados em diferentes ângulos do cenário organizacional e que apresentam diferentes expectativas e padrões de relacionamento com o receptor dos feedbacks tendem a focar prioritariamente em diferentes tipos de comportamentos. Assim os subordinados podem concentrar sua atenção e até avaliar com maior precisão itens como 'apóia o desenvolvimento de seus subordinados, atuando como coach. O mesmo ocorre com relação aos pares, em itens como 'participa da construção da estratégia da empresa'."

Para alguns teóricos da administração a criação de uma perspectiva para o funcionário assumir uma responsabilidade maior pelo planejamento e avaliação de sua própria contribuição para os objetivos da organização, pode ser encarado como uma evolução trazendo como efeito a satisfação de suas necessidades de auto-estima e auto-realização.

Uma empresa administrará com sucesso idéias inovadoras quando tiver completa aceitação da Teoria Y. É relevante lembrar que McGregor, desde o início do século XX, 
entendeu que só há duas maneiras de "olhar" o homem: de um lado o indolente e do outro o autoconfiante. Se a empresa o tratar de um modo ou de outro, será na mesma proporção que ele retribuirá, portanto dependendo de suas possibilidades de experimentar seu potencial e do espaço concedido, será o quanto ele poderá agir no sentido criativo e construtivo.

Os progressos na área de desenvolvimento tecnológico avançaram muito no sentido de garantir o desenvolvimento e a eficácia das organizações. Observa-se, porém, que o desenvolvimento humano carece dos conhecimentos das ciências humanas aplicadas à melhoria da própria existência. As implicações do conhecimento nesse campo também devem alterar os rumos do progresso da instituição empresarial e da própria instituição social que hoje é considerada planetária porque deve responder aos problemas que o planeta enfrenta diante de um contexto de transformações.

Para que essa convicção se torne realidade em vez de esperança sem muitos resultados, é preciso que o processo seja de libertação de uma energia a qual deve ser aplicada para fins transformacionais, para que se melhore a condição do desenvolvimento humano.

A competência tecnológica da administração industrial, com o objetivo de alcançar fins econômicos, transformou o que era sonho científico em pura realidade. Cuidar dessas mesmas qualidades, aplicadas ao lado humano, não deve e não pode ter como alvo apenas a produtividade. O desenvolvimento humano e a valorização do lado humano na organização devem engrandecer as realizações materiais, mas devem também levar as pessoas a estarem um pouco mais perto de uma sociedade mais justa, sentindo-se capazes de contribuir para essa reconstrução de caminhos para o homem do Século XXI.

Nesse ponto descobre-se um estímulo para reexaminar as opiniões sobre o lugar das pessoas nas organizações, pois sem dúvida as organizações ainda são bastante desumanas. Apesar de todas as críticas feitas à teoria e à técnica das relações humanas desenvolvidas a partir das pesquisas realizadas na fábrica de Hawthorne, com relato em 1938, entende-se que a teoria é correta e progressista, mas ela foi insuficiente, pois trazia uma perspectiva estreita demais para a análise da administração das organizações. É claro que sem ela não se teria avançado da Teoria X e não há mais razões para uma administração essencialmente dura, mas o que se deve procurar fazer é vencer a estagnação atual de opiniões sobre o lado humano nas empresas, o que parece prevalecer entre estudiosos e administradores das ciências humanas, destacando-se os administradores de recursos humanos. 
Essas opiniões de modo geral colocam algumas questões que são relevantes para o futuro da gestão com pessoas e consideram que:

- A organização é e deve ser essencialmente um sistema humano;

- Logo a administração da organização é e deve ser em essência, um processo de coordenação do esforço humano;

- Implicitamente, a melhor organização é aquela em que cada grupo contribua com seu potencial máximo e o melhor administrador é aquele que cria condições que levem ao máximo a criatividade e o empenho de cada membro da organização;

- A administração é um processo unificado e não diferenciado, ou seja, uma boa administração em um nível ou lugar deve ser tão boa quanto em outro, em qualquer organização.

Essas crenças devem ser revistas urgentemente, pois exigem um salto de concepção sobre o que é humano nas organizações. A racionalização do trabalho sempre foi considerada a essência pura da boa administração e se aplicava, em tese, a todos, da mais alta cúpula até o mais simples colaborador. Essas opiniões expressam uma crença na participação e elas têm como elemento comum à idéia de que as organizações são essencialmente humanas. Seguindo na análise das organizações em termos humanos, verifica-se que elas têm um valor muito forte: o de que não só as organizações são mais bem estudadas enquanto grupos humanos, mas que devem ser humanas.

Ao longo dos últimos anos, na história da administração a questão da resistência ou participação humana tem sido uma dificuldade, principalmente, quando ocorrem problemas como baixa produtividade ou insatisfação do cliente porque as empresas acreditam que com maior participação haveria maior possibilidade de se chegar a denominadores comuns, mas não é algo que acontece por imposição e a qualquer momento. Novos conhecimentos nos campos das comunicações e ciências humanas, que poderiam ter aplicação na solução de problemas na organização, muitas vezes não o são, porque administradores mais retrógrados se mantêm presos às idéias de que com a participação das pessoas e a criação de um espaço para esses novos conhecimentos haverá perda de controle e maior dificuldade para se lidar com a subjetividade.

Paradoxalmente, na realidade de hoje as pessoas aprendem que perdem com a desqualificação para o trabalho e que elas serão valorizadas como profisssionais se 
participarem com seus conhecimentos e competências. Mesmo assim são muitas as razões para que a manutenção de muita insegurança com relação à infalibilidade da crença na participação.

\section{4- Análise do Trabalho}

As transformações de que se tem tratado até aqui e que envolvem o fim de um século e início de outro, referem-se tanto ao campo da materialidade quanto ao campo da subjetividade/interioridade e conseqüentemente, a reestruturação na forma de produzir pode trazer mudanças profundas no interior do mundo do trabalho.

Observa-se que a lógica da sociedade industrial está baseada na produção de mercadorias e na valorização do capital. Ao longo dos anos a lógica do sistema econômico vem transformando conceitos de concorrência e a busca da produtividade não se separa de seu lado oposto que é o processo destrutivo.

O retrato revela elementos de precariedade do trabalho com o aumento da oferta de mão de obra e no número de desempregados. No mundo do trabalho vigora a lógica do capital, que apresenta um quadro crítico experimentado de modo geral em diversas partes do mundo. O processo de socialização humana acaba sendo condicionado aos interesses econômicos, referentes a uma ideologia da sociedade contemporânea, desprovida de uma orientação humanamente significativa.

Entende-se que o pensamento econômico e de mercado, como modo de regulação das trocas, atribuiu socialmente um espaço central às empresas. Em uma visão Marxista, durante muito tempo a empresa foi tida como um local de exploração, dominação e alienação, mas ao longo de um século tornou-se a instituição por excelência, fonte de riqueza e de cultura, destinada a resolver a maioria dos problemas que se enfrenta hoje.

Quando Peter Drucker (1981) procurou esclarecer como a prática do gerenciamento se desenvolveu ao longo da história da administração, isso também permitiu aos estudiosos compreender a conduta humana e o selo da instrumentalidade e da operacionalidade, que passaram a permear as relações humanas nas organizações.

Em um primeiro momento, que vai do fim do século XIX até a Segunda Guerra Mundial (1870 a 1940), retrata um esforço das empresas em sistematizar suas experiências e 
técnicas desenvolvidas com base na ciência: problema de produção, gestão científica e o indivíduo são vistos como um apêndice à máquina.

Em um segundo momento (1940 a 1980) é marcado pela presença das consultorias: consumo de massa, crescimento das empresas e a influência do profissional no desenvolvimento econômico.

Num terceiro momento, a partir de 1980, há uma mudança no discurso e no modo de gerenciamento, pois a eficácia orienta as ações nas empresas procurando atender aos imperativos financeiros e da economia de mercado, que se globaliza e obriga as organizações a reverem suas estruturas e processos para se manterem competitivas, com bases mais flexíveis e apoiadas na informatização e na tecnologia avançada. Surge um novo cenário de instabilidade profissional, desemprego e a gestão estratégica ganha espaço.

Para análise do trabalho verifica-se que o gerenciamento teve como foco o bom funcionamento de uma organização e a eficácia surge como sinônimo de lucro e rendimento em relação ao capital investido garantindo a participação no mercado e a produtividade. Essas exigências partem dos que dirigem e não dos dirigidos, mas não são apenas de ordem financeira, são também de ordem social e referem-se à rotatividade de funcionários, satisfação do profissional no trabalho, estabilidade no emprego, saúde e segurança.

Também estão presentes exigências externas como as sociais, as jurídicas, as ambientais, as fiscais e as sindicais, que obrigam a uma reconsideração do modelo de gestão e do discurso; surge um debate internacional e discussões em torno do desenvolvimento sustentável e da competitividade.

\subsection{1- A Transformação no Significado do Trabalho}

Uma pesquisa teórica no sentido de aumentar a compreensão sobre mudanças no mundo do trabalho não pretende trazer uma fórmula para transformar o mundo do trabalho e das empresas, mas pode contribuir para um posicionamento mais lúcido de transformar a visão das pessoas, tanto das que dirigem quantos daqueles que executam o trabalho.

Rever o significado dado ao trabalho e sobre o tratamento dado às pessoas na sociedade pós-industrial e posteriormente, com a filosofia da escola de qualidade, poderá servir como base para o realinhamento da função gerencial na era do conhecimento, envolvendo competências técnicas e humanas, pois capacidade de relacionamento no 
trabalho, aplicação de princípios de convivencialidade e aprendizagem compartilhada, tornaram-se um grande desafio para as lideranças.

De acordo com Corrêa (2003), a escola americana da qualidade, da qual Deming foi uma das figuras marcantes, criou raízes fortes no Japão e influenciou profundamente a filosofia de administração desse país.

Uma das empresas que mais aproveitou os princípios dessa escola foi a Toyota, porém essa contribuição da Toyota para a história moderna da administração foi muito além da simples incorporação e melhoramento da filosofia e das técnicas de qualidade. O Sistema Toyota de Produção, que vem evoluindo desde os anos 1950 é a semente do modelo japonês de administração e baseia-se não apenas nos especialistas da qualidade, mas principalmente nas técnicas de Henry Ford e Frederick Taylor.

O Sistema Toyota de Produção foi criado por Eiji Toyota, da família proprietária da Toyota e Taiichi Ohno chefe de engenharia da empresa, com uma visão sintetizada e melhorada das idéias de todos esses pioneiros da administração. Na verdade, o sistema Toyota é um estágio na história das técnicas que vêm evoluindo desde que os primeiros sistemas de produção foram inventados.

Para Maximiano (2000), os dois princípios mais importantes do sistema Toyota são: eliminação de desperdício e fabricação com qualidade. O princípio da eliminação de desperdícios, aplicado primeiro à fábrica, fez nascer à produção enxuta (lean production), que consiste em fabricar com o máximo de economia de recursos. O princípio de fabricação baseado na qualidade tem como objetivo de produzir, virtualmente, sem defeitos. Esses dois princípios possibilitam a manufatura de produtos de alta qualidade e baixo preço. Isso levou a Toyota, de empresa insignificante, à posição de terceira montadora do mundo, após General Motors e Ford. Para o bom funcionamento desses princípios, o sistema Toyota depende do comprometimento e envolvimento dos funcionários. Por isso a administração participativa, que promove a participação de funcionários no processo decisório, tornou-se o terceiro elemento importante do sistema Toyota, ao lado da fabricação com qualidade e da eliminação de desperdícios.

O sistema Toyota nasceu nos anos 1950, quando Toyota e Ohno, visitando a Ford no Estados Unidos, concluíram que o principal produto do modelo de Henry Ford era o desperdício de recursos (humanos, materiais, espaço e tempo). Fábricas gigantescas, pilhas de materiais em estoque, grandes espaços vazios. O sistema Ford desperdiçava inclusive, 
recursos humanos, por causa da especialização excessiva. Havia muitas pessoas nas fábricas, com especialidades limitadas, tais como cuidar exclusivamente de planejamento e controle da produção, compras, controle de qualidade, manutenção ou limpeza.

Para Corrêa (2003), a filosofia do modelo Ford, que havia influenciado toda a indústria ocidental, consistia em dispor de recursos abundantes, de todos os tipos, para enfrentar qualquer eventualidade. Os recursos deveriam fiar em estado de prontidão, para cumprir o programa de trabalho com segurança e lidar com as emergências. Essa era a filosofia do just in case (expressão que significa "por via das dúvidas" ou "só para garantir"). Até os anos 1980, as empresas ocidentais seguiram essa filosofia, acreditando que quanto maior, melhor.

O que para os ocidentais, porém, era preocupação e abundância de recursos, parecia desperdício para os japoneses, especialmente logo depois da Segunda Guerra, quando o país enfrentava dramática escassez de recursos. Para ser eficiente e competitiva, a Toyota precisaria modificar e simplificar o sistema de Ford, tornando-o mais racional e econômico.

Para Certo (2002), a idéia da racionalização da força de trabalho está na raiz de conceitos que viriam a ter grande importância na moderna administração: manufatura celular, autogestão e trabalho de equipe. Certos elementos do sistema Toyota e modelo japonês de administração são fortemente influenciados pelos valores da cultura nacional do Japão. Combate ao desperdício e trabalho de grupo são dois desses elementos.

O hábito de combater o desperdício é exemplo de traço cultural muito antigo. País pequeno, com poucos recursos naturais, o Japão estimulou em seus habitantes o espírito de economia e eficiência, a combatividade e a capacidade de cooperação para sobreviver num ambiente hostil. Depois da Guerra, a escassez de recursos tornou-se um longo período de trabalho duro e metódico. É natural que os japoneses tenham adotado seriamente a doutrina de aprimorar continuamente a utilização de recursos na administração de suas empresas.

À eliminação do desperdício os japoneses aliaram outro ingrediente importante do modelo de administração: o trabalho de grupo, que está enraizado em seus valores e hábitos desde tempos imemoriais, conforme afirma Maximiano (2002). A necessidade de cooperar e o sistema feudal que vigorou no Japão até a Era Meiji, no final do século XIX, tiveram forte influência sobre a capacidade de trabalhar em grupo. 


\section{Universalização do Modelo Japonês}

Até meados dos anos 1970, pouco se ouvia falar no sistema japonês no ocidente, e eram conhecidos apenas os círculos de controle da qualidade. O modelo americano dominava a prática e o ensino da administração em todo mundo. A única novidade estranha a esse monopólio era o sistema Volvo, de trabalho em grupo na linha de montagem. Desconhecia-se, nessa época, que os japoneses já aplicavam o mesmo princípio desde o início dos anos 1950 .

Quando os produtos japoneses adquiriram reputação de alta qualidade e baixo preço, e começaram a dominar os mercados em todo mundo, seus métodos de administração começaram a se tornar conhecidos. Esse interesse pelo sistema japonês intensificou-se nos anos 1980, quando empresas como Toyota, Honda e Nissan instalaram-se nos Estados Unidos e na Europa, impressionando as empresas locais com a superioridade de seus métodos de produção eficientes e sua maneira participativa e igualitária de tratarem os funcionários. Os americanos observaram com surpresa a estratégia de envolver os funcionários no processo decisório, a técnica do just in time e a abolição das distinções hierárquicas.

No Brasil, já no final dos anos 1970, haviam começado as primeiras experiências com círculos de qualidade. Algumas empresas, como Walita e Volkswagen, produziram manuais para treinar seus funcionários com as técnicas de Ishikawa. Na década seguinte, outras empresas fizeram modificações mais profundas, de natureza estrutural. Empresas como Brastemp, Mercedez-Benz e Freios Varga são alguns exemplos que introduziram, nesse período, as técnicas de produção enxuta.

Quanto mais se tornava conhecido mais o modelo japonês revelava a simplicidade de seus componentes: eficiência, qualidade e participação dos funcionários nas decisões. A receita era simples, e, na verdade, era ocidental. O modelo japonês era o modelo americano que por sua vez, tinha suas origens no sistema fabril da Revolução Industrial. Com o tempo, os ocidentais aprenderam a colocar em prática a versão oriental em seu próprio modelo. Nos anos 1990, o modelo japonês já havia deixado de ser exclusivamente japonês, tornando-se o padrão universal das empresas que pretendem alcançar e manter a capacidade de competir em escala global.

Para Zampolo (2003) a cultura de uma empresa quanto ao valor atribuído ao trabalho é reflexo dos valores e prioridades de uma sociedade maior. O sistema econômico capitalista privilegia o mercado livre que cria emprego e define seus propósitos, que são produzir riqueza e gerar lucros. Até mesmo em setores sociais que não visam lucro - na educação, na saúde, 
nos serviços sociais e nos órgãos governamentais - em geral o pensamento de gerenciamento determina uma mentalidade da eficiência pró-lucro. Entende-se então que o mercado livre é flexível, ele dá poder às pessoas, pede por inovação, por novas competências, estimula a ousadia de correr riscos e tirar o melhor das pessoas. Há dez anos, o modelo de corporação semelhante ao estilo japonês era visto como o futuro do mundo. Hoje o sistema econômico norte-americano domina o resto do mundo e a China, o Japão e a Alemanha, entre outros seguem o modelo global. Resta saber se esse domínio irá continuar ou se cairá, vítima de alguma mudança nos rumos do planeta.

A economia global deve procurar atender à satisfação de alguns objetivos econômicos. Está em questionamento se os homens, os especialistas, os técnicos têm condições de controlá-la ou se é ela que controla as pessoas, se ela existe para benefícios do globo ou apenas para uma minoria. Para efeito de uma abordagem que envolve relações humanas no trabalho estas questões podem parecer imensas, gigantescas, poderosas, mas os objetivos últimos são as pessoas, o que elas procuram para seu crescimento interior e sua realização profissional.

\subsection{2- Repercussões da Qualidade Total}

Atualmente, a qualidade é vista como uma questão estratégica que afeta a todos e a cada um dos processos de qualquer organização.

A qualidade de um produto ou serviço é a percepção do cliente do grau que o produto ou serviço atende às suas expectativas.Ao reconhecer a vantagem competitiva que a administração estratégica da qualidade pode gerar, as principais empresas do mundo, cada vez mais, empregam a qualidade de produtos e serviços como forma de aumentar a participação no mercado internacional. Em cada um dos casos, as empresas necessitam mudar o enfoque de suas ações em conformidade com as especificações do projeto do produto/serviço, para o atendimento das necessidades/ expectativas do cliente.

$\mathrm{Na}$ prática, essas empresas tentam ultrapassar as expectativas do cliente, em vez de limitar-se a atender, simplesmente, os seus requisitos.

O conceito da qualidade está transformando a indústria, ao desafiar a capacidade de sobrevivência das empresas em todo o mundo. A qualidade é questão crítica para as empresas emergentes das nações em desenvolvimento, que pretendem fazer parte da próxima onda de fornecedores para os ricos consumidores da América do Norte, da Europa Ocidental e do 
Japão. Além disso, a qualidade está se tornando uma questão cada vez mais difícil, devido à abertura de novos mercados internacionais e a um número cada vez maior de empresas em busca de participação nesses mercados. As empresas que pretendem concorrer nos mercados internacionais necessitam de algum tipo de mecanismo capaz de demonstrar o seu comprometimento com a qualidade.

Para Silva (2001), a definição da qualidade continua a envolver bens e serviços. A falta de uma definição clara torna difícil para as organizações, medir, controlar e gerenciar a qualidade. Existem algumas definições alternativas aplicáveis ao mundo dos negócios atuais e suas implicações e as principais são: qualidade como excelência, qualidade como conformidade a especificações, qualidade como adequação do uso e qualidade como valor para o preço. Gerenciar qualidade representa um desafio ao gerente de produção e serviços (operações), que precisa alcançar determinadas características e as percepções do usuário, que são difíceis de assegurar. Ainda assim, a percepção da excelência de um produto pode ser uma abordagem significativa de competência.

O projeto da qualidade de um produto é a chave para QFD-"Quality Function Deployment", que foi desenvolvido pelo Professor Yoji Akao, do Japão. O propósito foi criar um método de planejamento e execução do desenvolvimento do produto no sentido de linhas funcionais. Atualmente os serviços respondem por mais de $75 \%$ da força de trabalho nos países mais adiantados. Muitas das dimensões-chave da qualidade do produto se aplicam aos serviços, tais como atributos, especificações/conformidade e confiabilidade. Entretanto, as organizações de serviços têm requisitos especiais, que os manufaturadores não podem preencher. Foi apontado por Silva (2001) que as mais importantes dimensões da qualidade são: tempo, oportunidade, integralidade, cortesia, consistência, acessibilidade, precisão e responsividade - resposta rápida do pessoal de serviços para resolver problemas inesperados.

As organizações de serviço passaram a ter orientação para o produto e prestar forte atenção às transações do cliente e ao comportamento do empregado. O comportamento é uma característica da qualidade na transação que envolve contato humano. Os trabalhadores, portanto, não só trabalham, mas também ajudam a melhorar o sistema. Valorizados por sua inteligência em prática, foi essa mente do homem que possibilitou o desenvolvimento da tecnologia eletrônica, depois dos computadores e dos grandes responsáveis pela transformação dos sistemas de administração de empresa. 
Esse novo patamar possibilitou a implantação dos princípios de qualidade total e outras técnicas de gestão surgiram, como a pretensão de fazer com que o trabalhador conhecesse a empresa como um "todo" e não se limitasse às condições impostas por seu trabalho imediato. Esse "pensar a empresa como um todo" justifica-se na necessidade de uma concentração da economia, numa escala material enxuta e no objetivo de diminuição de custos, para tanto se tornou necessário contar com a visível capacidade de auto-organização dos trabalhadores.

William Edwards Deming, enquanto professor da New York University, viajou para o Japão depois da 2a Guerra Mundial a pedido do governo japonês para ajudar as suas indústrias a melhorarem sua produtividade e qualidade e desenvolveu uma filosofia baseada na crença do desejo do trabalhador de fazer um bom trabalho e na necessidade de fazer o poder sair da diretoria e levar a tomada de decisões para a fábrica. Os trabalhadores da fábrica aprenderam estatística para poder controlar gráficos do seu progresso em termos de melhorar a qualidade. Um trabalhador que raciocina no trabalho e conhece mais sobre processos de trabalho, favorece uma economia também na escala humana, pois esse indivíduo que aprende e pensa, torna-se polivalente, podendo cooperar em um maior número de atividades e com maior valor agregado.

Deming considerou que todos da organização, desde os membros da diretoria até os porteiros, deveriam receber treinamento em conceitos de controle de qualidade e estatísticas e todos estudariam a organização e sugeririam maneiras de melhorá-la. Esse homem, que recebeu o crédito por ter levado controle de qualidade para a indústria japonesa, foi enfático em afirmar que as empresas mudam quando as mudanças partem "de cima para baixo". Verifica-se, portanto, que esse "de cima" também está sujeito a um tempo médio que um diretor ou presidente ocupar nesse cargo de cima. Algumas mudanças podem ocorrer nesse meio tempo e, mais cedo ou mais tarde, pode surgir um novo ocupante para o cargo. Mas entende-se que as organizações e sociedades são a soma total de todas as pessoas que fazem parte delas. Transformar uma pessoa é começar o processo de transformar muitas pessoas. Se o próprio local de trabalho torna-se mais cuidadoso com as relações humanas, com a comunicação e não apenas com a eficiência e o resultado em curto prazo, as transformações ocorrem de acordo com a vontade das pessoas, uma pessoa por vez.

De acordo com Silva (2001) quando Armand V. Feigenbaum desenvolveu o conceito de controle da qualidade total (TQC) argumentou que a responsabilidade pela qualidade deveria ficar com as pessoas que executam o trabalho. Esse conceito é denominado qualidade 
na fonte e significa que todo trabalhador, secretária, engenheiro e vendedor deve ser responsável por executar o seu trabalho com qualidade perfeita.

O sistema Just-In-Time (JIT) tem sido chamado de um sistema de solução de problemas por decreto. Pelo fato de os inventários dos produtos em processo de fabricação serem reduzidos drasticamente, diminuindo-se os tamanhos dos lotes; qualquer interrupção faz com que a produção pare até que o problema que provocou a interrupção seja resolvido. Isso tende a melhorar a qualidade do produto de várias maneiras. Os círculos da qualidade, anteriormente denominados círculos de controle da qualidade, são encorajados por empresas japonesas e recebem substancial treinamento nos conceitos e técnicas de controle da qualidade. Os grupos freqüentemente se encontram fora do trabalho e combinam suas reuniões com atividades sociais ou esportivas. Eles tendem a selecionar seus próprios projetos de investigação e podem geralmente obter apoio da gerência na implementação das suas recomendações. Um círculo da qualidade (CQ) consiste em um pequeno grupo de empregados - o número médio é nove - que voluntariamente se reúne regularmente para a discussão dos projetos relacionados ao trabalho para avançar a empresa, melhorar as condições de trabalho e acelerar autodesenvolvimento mútuo. No final fazer a TQM funcionar está nas mãos dos funcionários. Eles têm de ser treinados, organizados e motivados e ter poder para conduzir produtos e prestar serviços de qualidade perfeita.

\subsection{3- Modelo da Descartabilidade}

Uma visão crítica do Modelo Japonês revela que as transformações no modo de conduzir a gestão organizacional vêm da própria concorrência entre grandes grupos produtivos e da necessidade de conter movimentos oriundos de lutas sociais vindas do mundo do trabalho. Essa nova forma de organização industrial baseada na inteligência dos trabalhadores pareceu estabelecer uma relação mais justa entre o capital e o trabalho, pois possibilitou ao trabalhador uma condição melhor de qualificação, de participação, de multifuncionalidade e de polivalência. Aumenta assim a possibilidade de maior realização pessoal no espaço de trabalho enquanto o perfil do trabalhador passa a requerer especialização com flexibilidade, que consiste na capacidade do trabalhador de inovar e contribuir para uma fase da sociedade capitalista, que tem base em novos conhecimentos para intensificar o trabalho. 
Drucker (1993) na sua obra "Sociedade Pós Capitalista" descreve como a cada uma ou duas centenas de anos ocorreu uma transformação aguda, que afetou grandemente a sociedade - sua visão de mundo, seus valores básicos, suas empresas e sua economia, e sua estrutura político e social. Para o autor, "estamos atravessando outra época de mudanças radicais, da Era do Capitalismo e da Nação-Estado para uma Sociedade do Conhecimento e uma sociedade de Organizações. O principal recurso na sociedade pós-capitalista será o conhecimento e os grupos sociais mais importantes serão constituídos pelos trabalhadores do conhecimento".

O modelo japonês de organização do trabalho, que substituiu o foco na produção de massa para especialização flexível, teve como prioridade o desenvolvimento organizacional, que nem sempre contava com resultados imediatos, pois requeria alterações de estrutura e traz implicações políticas e de poder. Novas técnicas forçaram o trabalhador a estabelecer um relacionamento mais cooperativo na relação de trabalho, pois requeria compartilhamento de informações. Assim, cabem aqui algumas considerações: a tecnologia computadorizada exige um trabalhador mais qualificado e isso não diminui a necessidade de intensificação do ritmo de trabalho para a implantação de novos métodos. Como ocorre na implantação do sistema just in time o objetivo é a consolidação de uma produção em larga escala e com acumulação intensa de valor aparente e sofisticação.

Nesse sentido, as mudanças não ocorreram num nível mais profundo, e ainda exprimiam uma contínua transformação dentro do mesmo processo de trabalho, alterando principalmente as formas de gestão e de controle dos processos e de pessoas. A falta de defeitos constituiu a qualidade na manufatura por muitos anos. Entretanto, a falta de defeitos isoladamente não satisfaria ou superaria a expectativa dos consumidores. Muitos administradores de alta posição têm constatado que uma melhor maneira de alcançar a distinção e encantar os clientes é por meio do projeto melhorado do produto, que está chamando a atenção dos fabricantes para alcance dos objetivos da qualidade e dos negócios.

Ampliando a visão sob essa forma de gestão, para Antunes (2003), a falácia da qualidade total revela que na empresa enxuta quanto mais "qualidade total" os produtos _têm, menor deve ser o seu tempo de duração. Existe uma necessidade imperiosa de reduzir o tempo de vida útil dos produtos, visando aumentar a velocidade do circuito produtivo e desse modo ampliar a velocidade da produção de valores de troca. 
Nesse sentido, qualidade total, entre outros, visa a invólucro e a aparência, mas com um aprimoramento do supérfluo, uma vez que os produtos devem durar pouco e ter reposição ágil no mercado.

Entende-se, portanto que o sucesso econômico advindo da qualidade total em meados da década de 1980 teve como base a capacidade da organização em reduzir o tempo entre a produção e o consumo. Para gerar riqueza, a qualidade total valorizou o visual, negou o princípio da durabilidade dos produtos e trouxe conceitos de consumo, que favorecem o desperdício e a destrutividade.

Portanto o mecanismo de produção em larga escala e a manutenção do quadro de empregados depende da faixa decrescente do valor de uso das mercadorias, pois prevalece o fenômeno que se refere apenas a uma aparência da mercadoria que favoreça o consumo em grandes quantidades e com a praticidade do descarte.

\section{Em Nome da Destrutividade}

Verifica-se aqui um agravante ao cenário vivido pelo homem do século XXI, pois pessoas desempregadas, sem lugar na sociedade podem, também, estar sendo vistas como seres humanos supérfluos.

Arendt (1989:149) argumenta que o homem trabalha sobre os materiais e fabrica a infinita variedade de coisas, que na soma total constitui o artifício humano, cuja durabilidade não é absoluta. O uso de objetos fabricados gera o desgaste desses objetos e a destruição é o fim intrínseco de todas as coisas destinadas ao consumo. Então o empregado não se identifica com o trabalho, mas com um processo. Aos excluídos do mundo de trabalho criam-se mais e mais obstáculos para que eles voltem a ter condições dignas de trabalho humano. As empresas que aceitam esses trabalhadores o fazem de forma temporária, exatamente porque são organizações com limitada capacidade econômica e dificilmente, poderão absorver e/ou qualificar essa mão-de-obra. E ainda, parece difícil encontrar uma empresa com capacidade de observar tantos desempregados até em virtude dos problemas locais que as afligem.

Desse modo essa cultura de consumo rápido despeja toneladas de descartáveis no lixo - um carro adquirido no ano é desvalorizado em torno de $20 \%$ do momento que sai da fábrica em até um ano de uso; a indústria de computadores apresenta forte tendência depreciativa, pois um software ou um novo sistema se torna obsoleto e se desatualiza em curto espaço de 
tempo. Observa-se que essa visão destrutiva do valor de uso das mercadorias pode estar sendo aplicada às pessoas, que representam a força de produção.

Para acompanhar a competitividade, a lógica da qualidade é enaltecida pelo conhecimento aplicado às inovações, uma estratégia organizacional que pode facilitar para que uma empresa não se torne obsoleta. É fato que esses efeitos têm como lógica a necessidade do capital se reproduzir e, considerando-se que os conceitos de superficialidade e desperdício orientam essa marcha, decididamente, pode-se estar caminhando exatamente para o lado oposto ao que deveria ser preservado. Nesse sentido, na vida em sociedade observa-se também que pouco se tem conseguido no sentido de agregar valores à sociedade e ao indivíduo, de evitar uma destruição degradante das condições da natureza e com a destruição do lixo gerado em sociedade.

Com as novas técnicas de trabalho, a empresa "enxuta" assimilou novos conceitos de trabalho e equipe, de células de produção, de "times" de trabalho e de grupos semiautônomos. Os trabalhadores, cada vez mais, são estimulados à participação, mas, contraditoriamente, a perspectiva do trabalho polivalente e qualificado e uma estrutura menos vertical nas empresas têm como objetivo menor redução do tempo de trabalho. Assim, se a empresa de sucesso, no modelo da Administração Científica de Taylor orgulhava-se do seu número de funcionários, nas empresas "enxutas" quanto menor o contingente de mão-de-obra altamente qualificada, maior será a sua produtividade.

Para o mundo do trabalho algumas condições já são constantes na ação empresarial, tais como: falta de regras e compromissos com direitos do trabalhador, seja no setor industrial ou de serviço; aumento da fragilidade no interior das entidades de classe trabalhadora, precariedade e informalidade na contratação de serviços e terceirização da força de trabalho. Se o modelo japonês foi uma opção viável à superação da crise capitalista da década de 1970 , o ocidente se interessou pelo modelo de performance e pelos círculos de qualidade mas não acrescentou à sua pratica empresarial ocidental, por exemplo o conceito de emprego vitalício. O ocidente importou as idéias de produção vinculada à demanda; trabalho operário em equipe e multifuncional; processo produtivo flexível, o que possibilita ao operário operar várias máquinas ao mesmo tempo; princípios do just-in-time com o melhor aproveitamento possível do tempo de produção; sistema Kanban, placas de comando para reposição de peças e estoques; estruturas horizontalizadas e gerência participativa; diminuição do foco da produção no interior da fábrica e transferência para "terceiros" de grande parte da produção; e, na organização dos Círculos de Controle de Qualidade - CCQ's. 
$\mathrm{Na}$ ótica de Antunes (2003) nas experiências das empresas com produção vinculada à demanda, a implantação de um sistema de trabalho com uso da alta tecnologia requer uma adequação da força de trabalho. Portanto as transformações humanas e organizacionais devem caminhar passo a passo com as mutações tecnológicas. O que se reconhece então é que, mesmo com a introdução de alta tecnologia, o preparo da força de trabalho implicará, cada vez mais, em transferir para o trabalhador o controle da qualidade, o bom atendimento ao consumidor e o aumento da produtividade. Cabe ao trabalhador introduzir elementos que possibilitem as alterações nos processos de trabalho, demonstrando novas competências para agregar valor ao seu trabalho. Esse mesmo princípio acabou sendo assimilado também pelo setor de serviços e outros.

A preocupação com as transformações humanas se deve ao fato de que a ciência e o paradigma cognitivo têm, numa visão determinista e objetiva, gerar um realinhamento da relação do homem com a sociedade e sua capacidade de produzir com conhecimento. Quando se considera o homem inserido no fenômeno social, entende-se também que são as interações entre indivíduos que produzem a sociedade. A cultura e as normas conduzem a ação dos indivíduos humanos, então os indivíduos se revelam dotados de elementos da cultura na qual estão inseridos. Assim pensar sobre essa transformação humana representa uma preocupação com noção de homem e sua relação com a sociedade. A visão sociológica mostra que as ciências não pretendem revelar o homem, mas dissolvê-lo em estruturas - abandona-se uma primeira idéia de que o homem tem também um destino social.

Uma crise estrutural do capitalismo reflete o esgotamento do padrão de acumulação desenvolvido no modelo taylorista/fordista, que Antunes (2003), define como uma expressão fenomênica: durante as seis primeiras décadas do Século XX e, caracterizado pelo forte acúmulo do capital, o objetivo empresarial era garantir o controle social da produção. $\mathrm{O}$ cenário da economia pós 2a Guerra Mundial foi marcado por queda da taxa de lucro, pois houve um aumento do preço da força de trabalho que foi conquistado pela intensificação das lutas sociais na década de 1960. Isso tudo levou a uma menor produtividade, que o capital traduziu como uma ameaça, a qual se acentuava com o decrescente patamar da taxa de lucro. Havia excesso de capacidade de produção do setor industrial.

Um fenômeno caracterizado por uma crise, demonstrou que a estrutura do capitalismo não estava em condições de responder à retração do consumo, sendo que esta retração já era uma resposta do desemprego estrutural que começava a surgir. Essa crise do sistema de produção trouxe um abalo para esfera financeira, colocando o capitalismo financeiro como 
uma "força para a especulação", principalmente porque era o início do processo de internacionalização e globalização. Com as fusões foi possível uma concentração maior de capitais entre as empresas monopolistas ou oligopolistas. A política de Welfare State, difundida pelo liberalismo norte americano também é abalada pela necessidade de se conter gastos públicos. Surge a necessidade de uma transferência de responsabilidades para o setor privado. Como saída para a crise há um incentivo às privatizações, à necessidade da flexibilização do processo produtivo, aos mercados e à força de trabalho.

Sabe-se que a resposta a esse aspecto destrutivo da lógica do sistema capitalista foi um intenso esforço para promover a reestruturação da produção e do trabalho na busca da estabilidade conhecida anteriormente. Na tentativa de encontrar uma solução, no final da década de 1980 e início de 1990 o sistema de produção capitalista fortaleceu sua autoridade e concentrou-se na busca de novos padrões de dominação baseados no conhecimento e tecnologia. Em nome da competitividade internacional o desenvolvimento tecnológico passou a ser fundamental para as empresas manterem uma condição de competitividade e isso afetou um conjunto de países. Quanto mais se expandiam os capitais financeiros dos países dominantes, denominados Imperialistas, maior se tornava a desestruturação daqueles que estavam subordinados às regras impostas. Países excluídos desse movimento de reposição dos capitais financeiros e produtivos ou do desenvolvimento tecnológico se tornaram dependentes e com profundas repercussões no interior dessas noções: desemprego e precariedade do trabalho.

Antunes (2003) entende que agravou também a crise da destruição, que vai além do enfraquecimento das forças produtivas, há destruição e agressão à natureza e ao meio ambiente, com forte desenvolvimento do crime organizado. Em escala mundial há uma ação destrutiva contra a força humana de trabalho, que eleva o nível de desemprego estrutural. Como tem sido enfatizado por teóricos da economia quanto maior a competitividade e a concorrência inter-capitais, isto é entre países dominantes e países subordinados, mais predomina o elemento destrutividade, tanto da força humana que trabalha quanto à exploração do meio ambiente.

É muito importante observar que essa é a lógica de uma sociedade que busca desesperadamente à volta de um padrão anterior perdido, ao mesmo tempo promove essa tentativa de reestruturação produtiva do capital, nega o esgotamento do modelo atual e define muito pouco sobre a busca de novas alternativas. Com o objetivo de recuperar padrões 
anteriores de produtividade, o incremento tecnológico visa produção de mercadorias e a valorização do capital.

Para reestruturar o padrão produtivo instituído pelo ideal taylorista/fordista, a resposta do sistema econômico tem sido considerar a crise enquanto um fenômeno que deve ser tratado como algo a ser eliminado e contornado por uma nova lógica de produção. Parece que não há um reconhecimento das mutações que ocorrem além da economia, ou seja, no ambiente, na sociedade, na política e nas ideologias.

\subsection{4- Ritmo do Capital e do Trabalho}

Dessa crise surgem repercussões na subjetividade e nos valores daqueles que vivem do trabalho. Na tentativa de reorganizar o ciclo produtivo, o capital tenta preservar seus fundamentos essenciais do modo de produção capitalista. A passagem do padrão taylorista para novas formas de acumulação flexibilizada revela apenas uma mudança de padrão, não no modo de produção, na busca de alternativas que aqueçam o processo de produção de bens.

O padrão produtivo introduzido por Taylor baseou-se na racionalização das operações, evitando desperdícios e reduzindo o tempo de produção com o aumento do ritmo de trabalho e melhor exploração de mão-de-obra. Esse trabalho caracterizou-se por ser fragmentado, pois embutia a especialização e a decomposição das tarefas. Numa visão reducionista desenvolvida por Isaac Newton extraiu-se a idéia de que a ação do operário se reduzia a uma rotina de atividades repetitivas e mecânicas, que no todo gerava o trabalho coletivo. O desenvolvimento das ciências e da tecnologia trouxe uma visão mecanicista do mundo e do modo de sobreviver.

Essa visão do homem como apêndice da máquina abriu espaço para a sociologia crítica e a teoria marxista que apontou para a condição do capital ser mais intensivo na extração do sobre-trabalho. O conceito econômico de mais-valia, introduzido por Marx (1971), mostra que a mais-valia é extraída do trabalhador com o prolongamento da jornada de trabalho e com o acréscimo da sua dimensão absoluta. A taxa de mais - valia foi o nome dado por Marx para a razão entre a mais valia e o capital variável. O capital variável representa o que foi investido na força de trabalho e a mercadoria é a fonte de valor.

O trabalhador trabalha sob o controle do capitalista, a quem pertence o seu trabalho. O capitalista cuida em que o trabalho se realize da maneira mais apropriada e em que se apliquem adequadamente os meios de produção, não se desperdiçando matéria prima e poupando-se o instrumental de trabalho, de 
modo que só se gaste deles o que for imprescindível à execução do trabalho. (MARX 1971:226).

Na visão de Marx (1971) o modo de produção capitalista envolveu duas grandes separações: uma é a separação das unidades em produção, o que em outras palavras significa que a economia capitalista é um sistema dividido em produtores interdependentes e concorrentes entre si e a outra é a divisão no interior de cada unidade de produção, entre os proprietários dos meios de produção e os produtos diretos, ou seja, entre capital e trabalho assalariado. Para o autor o capital é definido por duas coisas: o que ele é e como atua. Ele é uma acumulação de mais - valia produzida pelo trabalho, e essa acumulação pode tomar a forma de dinheiro, mercadoria ou meios de produção. Algumas das páginas mais brilhantes de O Capital são aquelas nas quais Marx descreve como, especialmente nas fases da revolução industrial, os capitalistas procuraram estender a jornada de trabalho tanto quanto possível, forçando até mesmo, meninos de nove anos a trabalharem três turnos de doze horas nas terríveis condições das fundições de ferro. Na obra "O Capital”, ele descreve: "é trabalho morto, que apenas se reanima, à maneira dos vampiros, chupando o trabalho vivo e que vive quanto mais trabalho vivo chupa".

Desde as primeiras décadas do século XIX o desenvolvimento do capital, nas grandes fábricas, mostrou que as ações dos indivíduos se limitavam a uma interligação de tarefas, com uma nítida separação nos postos de trabalho entre quem pensava e quem executava. A dimensão intelectual do trabalho, instituída por Henry Fayol, passou a ser de exclusividade do nível da gerência, que tinha a incumbência de fazer a parte mais interessante e atrativa da coordenação do trabalho. Com o desenvolvimento da indústria automobilística coube à gerência científica promover o modelo de produção e criar as bases para a solidificação da racionalização do trabalho e do padrão produtivo comprometido com a reprodução do capital.

O pensamento fordista contribuiu para vincular o comprometimento do capital com a democracia e o movimento operário com a social-democracia foi convertido para a ideologia do poder do sistema econômico com a subordinação dos organismos de representação. Conforme Heloani (2003), com a expansão do taylorismo, por volta 1910, os movimentos operários contrários à exploração da mão de obra fazem deflagrar greves e manifestações em todo o Estados Unidos. Quando essas greves ameaçaram a indústria de armamento e "atingiu o arsenal de Watertown, o governo saiu da posição da "neutralidade formal" e o Senado organizou, em 1911, uma investigação sobre as conseqüências do emprego no método desenvolvido por Taylor”. Essa investigação favoreceu os sindicatos e os métodos de Administração Científica apresentados por Taylor, foram proibidos em órgãos públicos. 
Outros países registraram forte oposição às idéias de Taylor. Com a eclosão da Primeira Guerra Mundial iniciou-se um forte apelo de cooperação entre as classes sindicalistas e patrões, mas apesar da atitude "amigável" os detentores do capital não deixaram de conter greves sustentadas por sindicatos locais.

A administração científica de Taylor, segundo Heloani (2003) ganha novo e inesperado campo de atuação quando passou a ser empregado pelos líderes da Revolução Russa, que apoiava os sindicatos e o estabelecimento de comissões que passaram a elaborarem meios e normas de produtividade para cada setor. Nesse período foram implantadas medidas de remuneração por peças, o aumento da jornada de trabalho e a radical expulsão para quem se "rebelasse" contra a proposta. Lênin como dirigente maior da União Soviética tentou apropriar-se da "cientificidade" de Taylor sob uma visão socialista, valorizando a perspectiva de "ensinar as massas" sobre a melhor forma de organizar o trabalho. Nesse sentido, o sindicalismo tornou-se um canal de mediação do comando do capital, representado pelo Estado, sobre os trabalhadores.

Em meados da década de 1960 e início da década de 1970, buscando um equilíbrio racional na relação donos dos meios de produção e trabalhadores, os sindicatos se fortalecem com o apoio de partidos políticos, que se posicionam como mediadores nas organizações da relação trabalhadores e patronato. Como árbitro o Estado protegeu os interesses gerais do sistema econômico.

O processo de trabalho proposto no modelo de Ford revelou uma contradição entre a produção e o consumo - por um lado, a vigência de técnicas da administração científica, associadas à disciplina imposta ao trabalhador e, por outro lado, o mesmo trabalhador lutando por um ideal de consumo. Aprendeu-se que o desgaste no trabalho seria compensado pelo aumento do poder de compra e, abriu-se aqui um precedente para o lado de ser humano para, dar espaço ao ter.

Nos Estados Unidos, um novo cenário marcado por ideais de outra geração produziu um boicote ao trabalho, cujo grande marco aconteceu no final de 1960 e início de 1970, com uma reflexão marcada pelo modelo do movimento "hippie", que questionava sobre guerras, sobre o pensamento de "perder a vida para ganhá-la", sobre o trabalho e sobre uma existência desprovida do sentido de paz e amor. A resistência ao trabalho se revelou nas fábricas por meio de altos índices de absenteísmo, pela busca de trabalho não-operário, por greves parciais, por operação "tartaruga" e por forte contestação sobre a divisão hierárquica do trabalho, que verticalizou brutalmente as relações, na tentativa do controle e direção do 
sistema de produção. As escolas administrativas ganharam espaço para atuar na organização industrial e com propostas de modelos de controle baseados na autogestão, dando ao operário maior poder e valorização do seu trabalho. A ação operária, apesar do fato de que os movimentos de luta sempre encontrarem limites para atuação, representou uma denúncia à organização industrial de modelo taylorista-fordista e à divisão social hierarquizada, que subordinou o trabalho às exigências do capital.

Ao longo dos anos, marcas da contestação social surgiram sob outras formas de movimentos como os ecológicos, urbanos, antinucleares, feministas, dentre tantos outros, exceto dentro das fábricas porque não houve forças para unir a sociabilidade humana ao vigor do capital. De certa forma o avanço tecnológico veio como a resposta do capital ao afrontamento do mundo do trabalho e com ele trouxe uma perspectiva de reorganização da produção, da necessidade dos clientes, da alteração dos processos de trabalho e novas perspectivas profissionais, agora sob pressão de acionistas. Descobriu-se uma possibilidade de ampliar lucros com a imaginação, a inteligência e a capacidade organizacional do novo operário, que agora poderia sair do aprisionamento ao local das máquinas para explorar sua capacidade de inovar e cooperar.

Mas para que contestar ou procurar ser feliz? Por que ganhar a vida? Por que viver afinal? O filósofo Albert Camus começa sua obra O Mito de Sísifo escrevendo, "julgar se vale a pena ou não viver a vida implica responder a pergunta fundamental da filosofia”. Cada ser humano quer viver, com compreensão ou não, possivelmente faz a mesma pergunta todos os dias e, a cada dia renova seu voto de fé a favor da vida. Talvez o direito reivindicado pelos trabalhadores do Século XXI passe a ser: esperar fazer mais do que se sustentar, descobrindo não só necessidade no trabalho, mas também a alegria de acreditar em si mesmo, de exigir o melhor de si mesmo e do seu local de trabalho.

\subsection{5- Trabalho e Reprodução do Capitalismo}

Para que o sistema econômico se reproduza, intensificando seu ritmo e alterando seus processos, essa sociedade do capital e seus valores emergentes necessitarão cada vez menos do trabalho estável e cada vez mais de formas diversificadas de trabalho parcial ou mesmo terceirizado. Há uma tendência de se pensar em uma diminuição do tempo físico de trabalho, redução de trabalho manual e ampliação do trabalho qualificado, que embute essa dimensão intelectual maior; no entanto a máquina não cria o valor de troca e o trabalho humano não pode ser eliminado. 
A reprodução do capital se dá por meio do consumo e esse consumo vem dos próprios assalariados, portanto há necessidade de uma articulação entre os tipos de trabalho e a manutenção do poder de consumo. $\mathrm{O}$ trabalho racional e mecanicista carregado de desgaste físico e mental vai continuar tendo espaço. Entende-se, portanto, que a redução do emprego/empregado estável, a antiga herança do taylorismo; a introdução da ampliação do trabalho intelectual; e, a precarização do trabalho por meio de terceirização e outros, criaram uma nova lógica para o mundo do trabalho.

Essa lógica faz com que os empregados estruturais procurem novas formas de realização na esfera de trabalho e uma vez "expulsos" do sistema, sua busca girará em torno de negócios próprios, de atividades em educação/capacitação e ocupação em organizações não governamentais e de serviços.

Considera-se que as ciências e o desenvolvimento da tecnologia não representam força produtiva, elas interagem com o trabalho. $\mathrm{O}$ conhecimento tornou-se necessário para o indivíduo participar do processo de valorização do capital e o saber mescla-se ao mundo do trabalho. A introdução do trabalho intelectual do operário coloca-o num processo de interação com novos conhecimentos e alterações nos processos de trabalho. Assim cada vez mais a força de trabalho deverá ser mais complexa e funcional e sua exploração mais intensa e mais sofisticada, principalmente nos tipos de produção que requeiram mais tecnologia.

Nesse contexto o trabalho intelectual que participa do processo de criação de valores também é uma mercadoria e tem seu valor de troca no mercado. Seria pura ilusão pensar que se trata de um trabalho intelectual dotado de sentido e compatível com a vontade do sujeito, marcado pela autodeterminação. É antes de tudo, um trabalho intelectual de raciocínio concreto que procura responder às necessidades de valor de troca no mercado, de reprodução das relações sociais e do autoritarismo aplicado à própria vida. Esse trabalho intelectual deve agregar valor ao indivíduo pela compreensão do sentido do saber e do conhecimento autêntico. Esse conhecimento autêntico deve estimular o indivíduo saber para onde vai e se o caminho escolhido o levará à autodestruição. Não basta o conhecimento para reproduzir o capital, é preciso compreender sobre o uso que se faz dele.

Uma aparente redução da separação entre quem pensa e quem executa, a diminuição de níveis hierárquicos e uma "subjetividade" maior na esfera da produção revelam um fenômeno paradoxal, pois mesmo contando com uma maior participação nos projetos que nascem das discussões entre trabalhadores, de maior envolvimento com processos e com clientes, permanece uma questão nessa relação trabalho-capital que é "a que se produz e para 
quem se produz". O trabalhador é valorizado, porque o capital precisa contar com a sua capacidade de pensar, agir e propor. Essa capacidade deve ir ao encontro das competências essenciais requeridas por uma organização e que, de alguma forma, visam o mercado consumidor e a sobrevivência da própria empresa.

O paradoxo está na maior liberdade na produção do trabalho e da necessidade das pessoas demonstrarem sua "aptidão" e sua disposição, pois caso ocorra o contrário, elas serão substituídas por outras que atendam ao perfil desejado e que possam acompanhar esses novos desafios do mundo do trabalho. Condição semelhante se aplica fora do ambiente de trabalho; o fato é que as pessoas, dada a necessidade crescente de se qualificar melhor e preservar sua condição de empregado, passam parte do seu tempo que seria livre, para descanso, investindo na sua empregabilidade, ou seja, tomando a responsabilidade por sua carreira, pelo desenvolvimento e qualificação, o que anteriormente era realizado sob o julgo das empresas.

No contexto da empregabilidade segundo Zaccarelli, De Domenico e Teixeira (2007:163) “as empresas estão interessadas na capacidade das pessoas de entregar resultados no menor tempo possível. Por outro lado essas pessoas devem dar sua contribuição e procurar oportunidades de desenvolvimento. Nessa relação, há um ganho financeiro que muitas vezes, terá uma parcela razoável atrelada aos resultados que alguém conseguir realizar. [...] A empregabilidade é a capacidade humana de gerir o próprio destino e prover meios para sobrevivência”. [...] Então o que se está dizendo é que não basta estar pronto para escolher e trabalhar em uma ou mais empresas ao longo da vida. A pessoa deve estar preparada para ser um profissional do conhecimento, um conhecimento que seja útil a ponto de poder ser 'vendido' para algum segmento da sociedade que esteja disposto a pagar por ele."

Então quanto à condição de empregabilidade, verifica-se que quanto mais qualificado é um profissional, mais o seu saber intelectual é transferido para máquinas informatizadas, que se tornam mais inteligentes também agregando valor e revitalizando o processo de trabalho de forma contínua. A racionalização das atividades permanece crescente, mas elimina a necessidade de um grande número de trabalhadores, pois o trabalhador em interação com a máquina não é mais o sujeito que opera a máquina é aquele que garante o funcionamento inteligente do equipamento. O paradoxo está na irracionalidade da condição humana a que todos estão expostos e nas formas como isso expande na sociedade, verifica-se que o trabalho autotransforma o ser humano e a natureza humana se altera com o processo de trabalho. 


\title{
1.4.6- Trabalho e Ser Humano
}

\author{
Conforme Lukács apud Antunes (2003):
}

A questão central das transformações no interior do homem consiste em atingir um controle consistente de si mesmo. Não somente, o fim existe na consciência da realização material; essa estrutura dinâmica do trabalho também se estende a cada movimento individual. $\mathrm{O}$ homem que trabalha deve planejar a cada momento, com antecedência, seu próprio rumo. Permanentemente ele deve conferir a realização de seus planos, fazer uma crítica de forma consciente sobre o que pretende obter com seu trabalho e como alcançar o melhor possível em um resultado concreto. Esse domínio do corpo pela consciência, afeta uma parte dos hábitos, instintos e emoções, e se apresenta como um requisito básico até no trabalho mais primitivo e deve dar uma marca decisiva da representação que homem forma de si mesmo. (LUKÁCS apud ANTUNES 2003: 143).

É possível compreender que a consciência humana é que possibilita a ação do homem na vida cotidiana. Quando as capacidades do homem extrapolam o pensar e o agir e revelam uma capacidade de pensar, sentir e agir, ele busca sentido para a própria vida, não como um conhecimento emprestado, mas referindo-se a sua sabedoria e a sua capacidade de compreensão. Uma vida com sentido encontra, no âmbito do trabalho, seu momento de realização diferente de acreditar que uma vida cheia de sentido se resume exclusivamente ao trabalho e à realização material.

Nesse sentido o tempo de liberdade tem um valor muito especial. Para De Masi (2000:16), “a espécie humana passou da atividade física para a intelectual, da atividade intelectual do tipo repetitivo à atividade intelectual do tipo criativo, do trabalho-labuta nitidamente separado do tempo livre e do estudo do ócio criativo, no qual estudo, trabalho e jogo acabam coincidindo cada vez mais (...)”.

O ócio é um capítulo importante nisso tudo, mas para os ocidentais é visto como um conceito negativo. Em síntese, o ócio, para De Masi (2000), pode ser muito bom, principalmente quando as pessoas se colocam de acordo com o sentido da palavra trabalho. Para os gregos, por exemplo, a palavra tinha uma conotação estritamente física - o trabalho era tudo aquilo que fizesse suar, com exceção do esporte. Quem trabalhava, isto é, suava, ou era escravo ou era cidadão de segunda classe. "As atividades não-físicas como a política, o estudo, a poesia e a filosofia eram consideradas "ociosas", ou seja, como expressões mentais, dignas somente dos cidadãos de primeira classe". Na visão do autor a sociedade industrial permitiu que o trabalhador usasse o corpo para agir, mas não havia tempo ou liberdade para expressar-se com a mente. A sociedade pós-industrial ofereceu uma nova liberdade: depois do corpo, liberta a alma. Entende-se que é da alma que saem os 
ensinamentos que permitem aos indivíduos lidar com a própria realidade. É na alma que reside o que é belo.

Nesse sentido compreende-se que as máquinas apresentam versões sofisticadas a partir da inteligência do homem, mas não substituem o homem na sua capacidade criativa. Buscar trabalho estará, cada vez mais, apoiado no conhecimento e na capacidade de usar a inteligência para atividades criativas de análise do sistema, de pesquisa científica, de psicologia, de marketing, de relações públicas, de tratamento de saúde, de turismo e lazer.

Na visão de De Masi (2000) a civilização grega pôde se dedicar ao trabalho intelectual porque havia condições para "ociar" ou seja, produzir idéias filosóficas, artísticas e políticas e, sob esse olhar, era preciso levar uma vida com mente e corpo sãos. Para desenvolver a criatividade torna-se importante cuidar da máquina mental e da física, pois a criatividade está mais ligada à capacidade de acolher e de elaborar, do que aos recursos disponíveis, mesmo que haja forte troca de idéias em um grupo criativo.

Na obra A Sociologia de Marx, Lefebvre (1968) aponta que o trabalho participa do movimento dialético "necessidade do trabalho-gozo", do qual ele é um momento prático e histórico. O homem como ser humano é visto como um ser de necessidades. A necessidade é, ao mesmo tempo, ato ou atividade e relação, em si mesma complexa, com a natureza, com outros seres humanos, com objetos. O trabalho não pertence à natureza, pois exige esforço e disciplina. É o trabalho que modifica a natureza em torno do homem e dentro do homem. Esses sentidos são cultivados e apurados pelo trabalho. O prazer reconcilia o homem com seu fundamento, a natureza. O trabalho substitui a necessidade como sinal de impotência, pela necessidade como capacidade de gozo, como poder de realizar tal ou qual ato. A superação dos limites visa realização total e a libertação da alienação.

Para compreensão desta tese de Lefebvre torna-se necessário entender que ao interiorizar idéias e necessidades, o indivíduo deva ter desenvolvido a capacidade de elaboração das próprias idéias. Esse ponto é fundamental, o de elaborar as próprias idéias.

Se por um lado, o homem busca o sentido da vida através do trabalho, ou seja, se é o trabalho que lhe permite o momento de realização, essa centralidade na visão labor efetiva-se na monetarização e na burocratização do poder do trabalho. Parece que é apenas o dinheiro que regula as relações entre sistema econômico e o mundo da vida. Entende-se que Marx e Engels, que representam os pensadores modernos mais influentes do Século XX, trataram desse paradoxo a partir de questões que abordavam democracia e controle operário. De modo 
a criticar as questões do mundo da vida subordinado aos interesses do sistema econômico, juntamente com os socialistas, seus nomes não poderiam deixar de ser mencionados pela visível influência que exerceram sobre os pensadores modernos, particularmente àqueles identificados com a corrente radical denominada de "esquerda participatória", conforme afirma Greenberg (1975).

Antunes (2003) traz alguns pontos da obra de Marx, de interesse para essa tese, pois trazem elementos importantes da forma como ele abordou a realidade social e as contradições do sistema econômico. Marx objetivou despertar a consciência operária para a sua missão histórica e revolucionária. O mundo do proletariado revolucionário, indissociável de sua autonomia, foi enfatizado no Manifesto Comunista e reforçado na Primeira Internacional. Num apelo à organização e união da classe proletária, Marx e Engels lideraram e organizaram a Associação Internacional dos Trabalhadores e diversos congressos internacionais, dos quais, dentre as temáticas mais abordadas, destacavam-se as questões das condições de trabalho, a tomada do poder, o controle dos meios de produção e a autogestão operária conquistados não de forma pacífica, como apregoavam os socialistas, mas pela revolução comunista. Enfatizaram também, o papel do sindicato, enquanto "centro de resistência contra as usurpações do capital", a sua atuação na abolição definitiva do trabalho assalariado e, particularmente, quanto à obrigatoriedade do controle dos trabalhadores sobre o processo de produção, de autogestão e da questão de participação e alienação do trabalhador. Para superar a alienação, de acordo com a teoria de Marx, a condição de participante das decisões da empresa não é suficiente: é indispensável participar dos mecanismos de controle da sociedade.

O modo de produção capitalista, numa visão marxista, se alimenta das tarefas da reprodução material do mundo da vida. E o trabalho é entendido como resposta à vida cotidiana, aos seus questionamentos e necessidades. $\mathrm{O}$ mundo da vida ocorreria na falha da esfera da liberdade e a liberdade existiria quanto maior fossem os conhecimentos das causas presentes e operantes no sistema, pois os conhecimentos poderiam ser transformados em ferramentas para combate às causas. Entende-se que com o conhecimento maior haverá o domínio do sujeito sobre as causas, o que equivale dizer que maior será a esfera da liberdade. Por outro lado essa separação entre sistema de produção e mundo da vida se consolida sob forma de desolação e empobrecimento cultural sob o olhar da complexidade da sociedade moderna. Torna-se importante explicitar que o pensamento de Marx não basta para o conhecimento do mundo atual, mas é necessário. 
Enquanto o sistema engloba as esferas econômicas e políticas voltadas para a reprodução societal, esfera que têm como meios de controle o dinheiro e o poder, o mundo da vida é o lócus do espaço inter-objetivo da organização dos seres em função da sua identidade e dos valores que nascem da esfera da comunicação. A cultura, a sociedade e a subjetividade, como dissemos acima, encontram seu universo, no mundo da vida. O desacoplamento entre sistema e mundo da vida só poderá ser compreendido na medida em que se possam aprender as transformações que vêm ocorrendo nas relações entre ambas. (ANTUNES 2003:149).

\subsection{7- Gestão da Comunicação e Subjetividade}

Primeiramente torna-se importante uma reflexão sobre o sujeito em situações concretas da vida cotidiana aplicada, diferentemente de um ser absoluto, autônomo ou determinado pelo seu meio, segundo a tradição gramatical e das ciências humanas em geral. As pessoas no seu cotidiano de trabalho podem ser reconhecidas pelo modo como agem entre si e com outros, pois elas estão desempenhando papéis estabelecidos pela organização.

O desenho de cargos moldados pelas organizações constitui-se, basicamente, de regras institucionalizadas e firmadas em contrato, que servem de parâmetros para os direitos e deveres do trabalhador. Ao conviver com outras pessoas cada um aprende a reconhecer essas pessoas independentemente de seus papéis e da interpretação que é feita em função de cargo ou atividades. O fato é que as pessoas são reconhecidas também por sua natureza humana, pois elas são dotadas de razão e vontade; tanto observador quanto observados são levados constantemente a avaliar, julgar, criticar e formar juízos de valores uns em relação aos outros. Essa compreensão do sujeito, independentemente dos papéis revelados na interação social, permite que se revele também uma capacidade latente para cada um saber agir em situações novas ou em diferentes realidades. De qualquer forma um papel existe em função do seu reconhecimento pelo "outro", implicando a existência de uma segunda pessoa.

Nas relações de trabalho, um mesmo ato ou gesto pode adquirir um sentido de cooperação ou de competição, dependendo das circunstâncias da comunicação: de quem partiu e para quem foi endereçada, onde e quando foi realizado. O que acaba sendo importante é a imagem que as pessoas constroem umas das outras, pois ao atuarem nos contextos organizacionais, os indivíduos orientam-se por valores e conhecimentos de mundo, acumulados por suas histórias pessoais.

Em comunicação se houver intenção de fazer-se presente no outro, não se deve enganar pelo estereótipo que se acredita serem o sujeito e o mundo circundante marcados por 
formalidades e regras pré-estabelecidas. A comunicação pode contribuir para um amadurecimento sobre o sentido dos "papéis" e o quanto eles são "conversáveis", pois em contato com "o outro" o sujeito também se revê e pode aprender a partir de outros ângulos, de outra visão e outros conhecimentos. Se os papéis podem ser modificados, isso justifica a importância do diálogo ou processos argumentativos para a legitimação de novas ações na sociedade. Para se pensar em transformação no âmbito das organizações, uma nova ação estará baseada na capacidade, ou no domínio do pensar, sentir e agir. Com a introdução do conceito de convivencialidade se reconhecem novos caminhos para as pessoas quanto ao estabelecimento de acordos, baseados em regras mutuamente reconhecidas e com a identificação do sujeito e da sua individualidade, capazes de se responsabilizarem pelo nível de desempenho de sua ação.

Acredita-se que a complexidade cada vez mais presente nas organizações contemporâneas obriga cada uma delas a seguir por caminhos que incluem a diversidade de tecnologia, de conhecimentos, de mercado, de culturas e de pessoas, o que tem transformado profundamente a dimensão do diálogo na comunicação organizacional.

Para Zarifian apud Davel e Vergara (2001), a comunicação continuará sendo uma questão difícil, pois formas contraditórias convivem na empresa e esta incorpora relações de subordinação e formas hierárquicas que tendem a instrumentalizar a comunicação, de modo que se faz dela um instrumento do exercício de poder e de coerção sobre os trabalhadores. Zarifian defende a tese de que:

[...] "apesar do peso sempre presente nessas relações de subordinação e apesar da redução da comunicação à transmissão de ordens e diretrizes, as quais os assalariados deverão executar, uma comunicação autêntica, de natureza intersubjetiva, emerge na empresa moderna, bem como ela emerge com força suficiente para poder ser reconhecida como estando no cerne das práticas de gestão". (Zarifian apud DAVEL e VERGARA 2001: 151).

A herança do taylorismo trouxe o ideal da comunicação zero. O operário era pago para produzir e deveria estar engajado nas operações de transformação da matéria em produtos tangíveis e acumuláveis. Logo, o ato de comunicar não produzia nada, não gerava valor econômico e ao contrário poderia ser visto como perda de tempo.

A partir de uma concepção autoritária de controle social e a concepção do homo economicus, a teoria X, apontada por Douglas McGregor, favoreceu na comunicação uma visão de que todo discurso dos executantes devia ser entendido como algo suspeito, pois exprimiam formas de resistências dos empregados para com as diretrizes hierárquicas e traduziam contestação da ordem. Essa visão pôde ser observada no contexto da experiência de 
Hawthorne quando "as moças da sala de relês", diziam que na sala de experiência não havia supervisão para controlar e que o ambiente era agradável.

Para Frederick Taylor esses enunciados dos discursos traduziam uma visão empírica do trabalho, expressavam um savoir faire operário espontâneo, não sistematizado e portanto, não científico e por definição, pretendia-se descartar. Como resultado disso tudo, o discurso e os intercâmbios sociais foram desacreditados, mas sabia-se que eles existiam, pois seria impossível impedir as pessoas de utilizarem as palavras e tentarem se comunicar durante os períodos em que trabalham juntos.

A mesma experiência de Hawthorne revelou a existência de grupos informais talvez tolerados, considerados de pouca abrangência ou legitimidade. Os operários deveriam ser educados para fazer, por eles mesmos, as tarefas que deveriam executar e a comunicação serviria para dizer aos operários sobre o que fazer e o como deveria ser feito. Portanto a comunicação foi considerada de modo unilateral e supõe que os operários aceitem submeterse a esse regime de "não palavra" e assumam um compromisso nesse sentido. A linguagem que se desenvolveu foi técnica, elaborada por engenheiros, como a de Taylor, que tinha como função conceber, preparar e controlar o trabalho dos empregados.

Zarifian (2001) observa que essa linguagem técnica e a "não linguagem" do operário manifestam sua ambivalência do ponto de vista da dominação que elas encarnam. Entende-se que há uma privação da palavra aos executantes então ela representa uma negação do valor de seus saberes e de seus pontos de vista sobre a produção. Do ponto de vista do conhecimento, são os engenheiros e técnicos que com seus serviços funcionais prestam o verdadeiro serviço intelectual. Nessa relação entre técnicos e operários, o compromisso se fixa no alcance de produtividade no trabalho e em troca no aumento regular de salário. Portanto a aceitação "silenciosa" desse acordo trazia a promessa de uma melhora permanente do nível de vida.

Nos ensinamentos de Taylor, esse compromisso do operário não lhe permitia engajarse subjetivamente ao trabalho. Ele era pago para trabalhar. Taylor não pediu ao operário para aderir às finalidades e aos objetivos da empresa e de maneira geral, não lhe pediu nada em termos de engajar-se subjetivamente ao trabalho para que a sua subjetividade fosse preservada. Zarifian (2001) aponta que:

"Astuciosamente, Taylor aprisiona os operários em sua própria teia: a da valorização de um "outro lado", aquele de seu abrigo familiar e de seu nível de vida, ou seja, aquele de pertencer a uma mesma classe social, "outro 
lado", esse permite não se engajar subjetivamente diante do patronato, de não perder sua independência de pensamento. ( Zarifian 2001:154).

Entende-se que "pensar" fica para fora da fábrica, portanto, no interior dela o pensamento deve permanecer silencioso. Essa boa troca mostra que o operário deveria concentrar-se em seu trabalho e ainda teria a sua independência respeitada. Se a área de comunicação pode apoiar a gestão com pessoas, os profissionais de comunicação também devem aprender que a herança do modelo taylorista amplia seu campo de investigação e se apresenta como um desafio, pois quem se propõe a lidar com essa pesada carga, percebe que a privação da palavra legítima trouxe à tona o fator de alienação do empregado: a eficiência se resume a um regime de produção e focos particulares não pertencem à organização.

Ao estabelecer um contrato de trabalho o assalariado aceita fornecer uma prestação de trabalho em benefício do empregador e, portanto, subordina-se juridicamente ao último, por meio de uma remuneração. Essa relação se traduz por direitos do empregador de determinar sobre o trabalho e pela obrigação do assalariado de executá-lo. Uma dimensão desigual de comunicação está explicitada nos direitos e deveres e nos dias de hoje essa condição foi assimilada como algo natural, porém que esconde uma profunda contradição: discute-se o conceito de civilidade e de reconhecimento de direitos democráticos de um lado e do outro, o reconhecimento oficial da relação de subordinação ao empregador.

Para Thurow (1997), democracia e capitalismo têm crenças muito diferentes com relação à distribuição adequada do poder. A democracia acredita numa distribuição de poder político, pois um homem representa um voto. O capitalismo acredita que é dever dos economicamente aptos empurrar os ineptos para fora dos negócios, ou seja, para a extinção econômica. Afirma: "sobrevivência do mais apto e desigualdade em poder de compra são a essência da eficiência capitalista. Indivíduos e empresas tornaram-se eficientes para serem ricos. Colocando em termos claros, o capitalismo é perfeitamente compatível com a escravidão”. De acordo com esta visão do autor , em uma economia com uma desigualdade crescente, essa diferença de crenças a respeito da distribuição adequada do poder representa uma falha de enormes proporções, "esperando para desabar". Entende-se que aqueles que defendem o capitalismo normalmente afirmam que ele irá prover rendas reais crescentes para quase todos e, só às vezes, admite-se que as desigualdades tendem a crescer cada vez mais.

No final, a tensão entre esses dois fenômenos pode ser considerada uma questão estrutural na evolução de práticas gerenciais, pois essas práticas podem estar reafirmando um 
tipo de compromisso de defender exclusivamente o interesse do capital, o que é paradoxal perante as necessidades da Era do Conhecimento, da valorização do capital humano como fator diferencial para a competitividade das empresas.

O conhecimento tornou-se uma forte condição de vantagem competitiva sustentável em longo prazo e depende do nível de desenvolvimento dos empregados. É por essa razão que se estuda e se pesquisa sobre novas aprendizagens, desenvolvimento de competências organizacionais e de competências e habilidades individuais.

\section{5- Ação no Trabalho}

Considera-se que a escala de competição na economia global e a revolução da informação, qualidades dos produtos e serviços, e inovações criadas pelo mercado, tornaramse quesitos essenciais para a sobrevivência no mundo dos negócios. Trata-se de um processo em andamento, pois foram os japoneses que desde os anos 1980 atingiram os mercados mundiais e ameaçaram americanos e europeus. A lista na época envolvia, entre outras, empresas como Canon, Honda, Toyota e Sony em multimídia e soluções para net.

Criar vantagens competitivas através da inovação do produto, qualidade ou serviço exigiu um novo pensamento e um novo comportamento gerencial. Para Handy (1991), foi em face dos novos imperativos - flexibilidade, competitividade e globalização - que a gestão passou a depender de mão-de-obra móvel, competente, em boa forma e entusiasta e, particularmente, preparada para afrontar as reestruturações constantes e os tempos da virtualidade. A cada período, as ciências humanas são convidadas a trabalhar no sentido de criar subsídios para que o capital humano responda aos imperativos da necessidade de eficácia emergente.

Inicialmente as transformações dos conteúdos profissionais e das ocupações, em função da automatização e da informatização, definiram novas e diferentes competências para as estratégias de negócio de uma organização e a partir dos anos 1980, aumenta a responsabilidade de operadores sobre conhecimentos nos processos de trabalho, cada vez mais amplos e integrados. Ocorre assim a crescente integração aos desempenhos produtivos da competência técnica, que por sua vez gera o desempenho econômico. Neste sentido, saber sobre a organização e sobre o negócio requer uma competência de otimização para funcionamento e para mudanças pontuais. 
No caso da avaliação da competência de serviço, apontada por Zarifian (2001), devese associar a necessidade da competência técnica ao impacto que um produto traz como benefício agregado a seus destinatários.

Considerando-se que pessoas e organizações interferem mutuamente no processo de construção e gestão de competências, uma noção de reciprocidade se sustenta na medida em que as empresas buscam o desenvolvimento de seus talentos com o intuito de retê-los na organização. Espera-se das pessoas vontade de agir e colocar em prática seus conhecimentos, habilidades e atitudes, que favoreçam um movimento de transformar o estoque de saberes em competências e que agreguem valor à empresa, aos clientes e ao próprio profíssional.

\subsection{1- Definição de Competência em Estudo e a Inclusão da CHAVE}

O dicionário Houaiss (2004) apresenta, no sentido figurado, a definição de competência associada ao indivíduo de grande autoridade num ramo do saber ou do fazer, o que implica mesmo que informalmente, em conhecer e fazer e, no sentido psicológico, como a capacidade objetiva de um indivíduo para resolver problemas, realizar atos definidos e circunscritos. O dicionário Aurélio (2001) define competência como a faculdade para apreciar e resolver qualquer assunto e acrescenta-se a ela idoneidade e aptidão. Então competência é uma qualidade de SER, uma capacidade de adequação com o efetivo domínio de habilidades, conhecimento e qualificação ou capacitação.

A competência não pertence ao mundo empresarial nem ao mundo do trabalho, ela está no cerne de toda ação humana individual ou coletiva. Na escola, quando os alunos freqüentam cursos com o objetivo de desenvolver um aprendizado, que será aplicado à vida pessoal, política, cultural, associativa, econômica e profissional, eles iniciam um processo educacional que levará ao desenvolvimento de competências. Quando os alunos aprendem, o saber fará parte de suas ações, aplicado aos cenários existenciais.

Na visão de Perrenoud (2002) a competência pode ser compreendida como um saber agir com responsabilidade. Do inglês "responsibility" abstrai-se a idéia de que a responsabilidade é desenvolvida a partir da habilidade de dar respostas. Um profissional “operador" é competente quando consegue mobilizar e colocar em prática, com eficácia, as diferentes funções de um sistema de pensamento que abrange recursos tão diversos quanto operações de raciocínio, conhecimentos, ativações da memória, avaliações, capacidades relacionadas ou esquemas comportamentais. 
Para Perrenoud (2002), os recursos cognitivos mobilizados no trabalho, como competências que agregam valor, são de natureza diferente e envolvem saberes, capacidades e outros recursos mais normativos. Os "saberes" referem-se a saberes declarativos como modelos da realidade, saberes processuais, o saber como fazer e as técnicas, saberes condicionais, saber quando intervir e de que maneira, e informações enquanto saberes locais. As capacidades ou habilidades referem-se a "conhecimentos para saber fazer esquemas de percepção de pensamento, de julgamento, de avaliação". Os outros recursos normativos referem-se a "atitudes, valores, normas, regras interiorizadas e certa relação com o saber, com a ação, com o outro, com o poder".

Psicólogos e educadores vêm discutindo há décadas o tema competência, abrindo campo, a partir da década de 1970, para discussões acadêmicas e empresariais envolvendo a compreensão da competência do indivíduo e a competência das organizações. O termo competência não é característica de uma pessoa e deve-se evitar a confusão entre comportamento e competência. Considerando a origem em latim competentia, verifica-se que o seu significado é acordo, assim entende-se que a partir de um acordo ou adequação do conhecimento à tarefa é que se pode pensar em competência. Ela não está dissociada do sentido e da relevância de sua aplicabilidade ao contexto de transformações no mundo do trabalho, das redefinições de paradigmas que orientam as sociedades, das empresas e da relação profissional-indivíduo-empresa e principalmente, da condição apresentada nesse trabalho que favorece a importância da visão da comunicação como competência de apoio aos gestores organizacionais e demais membros.

\section{Conceito de "CHAVE"}

Para compreender a importância da discussão sobre competências é necessário constatar que elas ocorrem no nível da pessoa, como uma competência individual e no nível das organizações como competências essenciais. Acrescenta-se ainda a competência no nível das nações, como sistemas educacionais para formação de competências, o que ainda é muito pouco debatido, mas que coloca o país cada vez mais afastado dos índices classificatórios de desenvolvimento humano.

Para Fleury (2002:55) “o conceito de competência é pensado como o conjunto de conhecimentos, habilidades e atitudes que justificam uma alta performance, acreditando-se que as melhores performances estão fundamentadas na inteligência e na personalidade das 
pessoas". Observa-se que a partir dessa visão do "CHA" - conhecimentos, habilidades e atitudes, de McClelland e emprestada por Fleury, é possível expandir a perspectiva de competência associada a um novo modelo mental, baseado na internalização ou interiorização desses saberes, com um significado de que a competência muda o nível de atuação das pessoas. Nessa ampliação da visão, dar significado ao saber comportar-se ou agir com responsabilidade, implica reconhecer que as competências são desenvolvidas a partir da vontade interior do indivíduo. Portanto competência também pode ser entendida como um conjunto de capacidades humanas que revelam a forma de pensar, sentir e agir, mas se no conjunto estiver desequilibrado passa a negar a perspectiva de uma alta performance.

Aprende-se sobre modelos, técnicas e comportamentos adequados à sobrevivência organizacional, que muito pouco incorporam dos processos interiores dos indivíduos. É paradoxal, mas hoje é a interioridade que faz a diferença real na performance da pessoa e, por conseqüência, na ação do profissional. Sem a vontade das pessoas, os conhecimentos não são aplicados, as habilidades não se convertem em melhorias de processos e a atitude de aprender e compartilhar parece cada vez mais impossível.

Por isso é preciso apresentar o conceito de "CHAVE” de Macarenco e Zamora (2006), que se refere aos fatores Vontade e Expressão, agregados aos Conhecimentos, Habilidades e Atitudes. Vontade e Expressão referem-se aos processos interiores ao indivíduo, que permitem a realização da "entrega" proposto por Dutra (2001). A “entrega” diz respeito aos conhecimentos, habilidades e atitudes com os quais o indivíduo contribui nos processos de trabalho e que geram valor agregado. O nível de entrega para Dutra (2001) envolve a capacidade de lidar com o conceito de complexidade, prevalecendo algo que vai além do cargo ou nível hierárquico da pessoa na empresa, pois a complexidade requer adequação às novas realidades, atuação consciente para efetivar possíveis alterações de processos de trabalho, que visariam eficiência dos atuais sistemas de gestão. A relação entre pessoa e trabalho é estimulada a partir das necessidades da organização, que propicia um espaço ocupacional mais desafiador e esses desafios apontam para a necessidade das pessoas terem vontade de criar um verdadeiro elo.

Ao introduzir o conceito de CHAVE acredita-se que para estimular Vontade e Expressão da inteligência para ações exteriores deve haver uma melhor compreensão do conceito de performance a partir da visão das múltiplas inteligências e da personalidade das pessoas, isto é, como elas agem emocionalmente. Esse conjunto de capacidades aliado à 
vontade de cada um permite ao indivíduo desempenhar com eficácia determinadas tarefas, ser responsável por suas ações e atender às necessidades organizacionais.

As competências requeridas dos profissionais referem-se, segundo Fleury (2002), a um saber agir com responsabilidade, que envolve capacidade de trabalhar em equipe, liderança, criatividade, iniciativa, e o uso de alguns recursos pessoais como empatia, adaptação às mudanças e ao novo, pensamento ou visão estratégica, e orientação para mercado, para o negócio da empresa e a necessidade do cliente.

Acrescenta-se a essa visão que competências que não se aprendem por educação formal dependem da compreensão do indivíduo em querer lidar com seus limites e com seu potencial para desenvolvimento. Para Goleman (1995), escritor da obra Inteligência Emocional, lidar com essa inteligência favorece ao indivíduo aprender lidar consigo mesmo, com seus talentos, limitações e desafios para então poder lidar com o potencial e as limitações do "outro".

$\mathrm{Na}$ visão do autor é a partir dessa competência emocional que alguém será requisitado ou não para trabalhar em uma organização, que alguém será reconhecido como talento, será deixado para trás ou promovido, independentemente das competências técnicas, pois essas ele poderá desenvolver rapidamente com pesquisa, estudo ou assessoramento individual.

A competência não é um estado, não se reduz a um conhecimento específico, depende de aprendizagem e é nutrida pela comunicação e pelo estímulo à implantação de um sistema de avaliação contínua. O conhecimento é que insere pessoas e organizações na esfera das competências e é a comunicação que deve cuidar com eficácia das relações humanas e da geração das novas competências requeridas.

Nesse sentido atrair e manter funcionários com habilidades técnicas e comportamentais, de acordo com o negócio da empresa, requer um trabalho mais cuidadoso ao se procurar selecionar pessoas com perfil de um conjunto de conhecimentos, habilidades e atitudes, o mais próximo das competências essenciais que as empresas transparecerem junto ao cliente.

\subsection{2- O Paradoxo Educacional do Capital Humano}

As teorias sobre Capital Intelectual demonstram que as empresas dependem da força, dos talentos e dos conhecimentos das pessoas que nela trabalham e que se transformam 
em Capital Humano, o qual está relacionado às competências, habilidades e agilidade intelectual do indivíduo. Para Cattani (2006), a Teoria do Capital Humano é uma derivação da teoria econômica neoclássica e, ao mesmo tempo, uma atualização, do axioma liberal do indivíduo livre, soberano e racional. Seu prestígio é cíclico. Com a crise do modelo tayloristafordista, ela ressurgiu, associada à redefinição das relações de trabalho na empresa e do papel do sistema educacional. Posteriormente, as propostas de valorização da força de trabalho através da educação sobreviveram sob o enfoque das Relações Humanas, perspectiva também recorrente na gestão da força de trabalho desde os anos 1930. Em função de mudanças no gerenciamento do trabalho, a Teoria do Capital Humano alcançou, nesses últimos dez anos, um grande prestígio. Ela se relaciona às práticas e aos debates que dizem respeito à segmentação do mercado de trabalho, à politecnia, à polivalência, à flexibilização e à qualidade total. Ela se situa, também, no campo de discussão sobre o neoliberalismo em educação (Gentili, 1995) e sobre o papel da formação dos trabalhadores como elemento emancipador ou condicionador da ação.

A Teoria do Capital Humano fundamenta-se na crença de que todos os indivíduos têm condições de tomar decisões livres e racionais. Observa-se aqui um paradoxo sobre a formação do capital humano, o que exige uma reflexão em dois quesitos. O primeiro é a de que as desigualdades sociais e as diferenças na distribuição de renda são de responsabilidade dos próprios indivíduos. Alguns investem mais na sua educação, garantindo rendimentos superiores; outros acomodam-se em patamares inferiores. O segundo, decorrente do primeiro, é que o sistema educacional apenas responde às demandas individuais, não tendo como atribuição promover a igualdade de oportunidades. Legitimam-se, assim, as propostas de desmantelar o setor público, de transformar a educação num negócio submetido à lógica do mercado. Os processos educativos passam a ser de iniciativa empresarial, atendendo a interesses particulares e localizados (Gentili e Silva, 1994).

\subsection{3- O Roteiro da Competência para a Empresa Competitiva}

Em um contexto de transformações na sociedade, na economia, no mercado de negócios, no mercado de trabalho e nos desafios para se manterem competitivas, as empresas devem alinhar o potencial de seu quadro de pessoal com as necessidades de seus clientes, se apresentando no mercado com uma imagem de empresa que dá resultados, atinge a satisfação de seu cliente e tem um negócio que deve continuar prosperando. Essa empresa pode manterse na competição com outras empresas concorrentes. 
Em conseqüência da forte pressão do ambiente externo, há uma quebra no modelo tradicional de gestão, que introduz mudanças internas para uma busca acelerada de flexibilidade, prontidão e qualidade. Esses três elementos-chave possibilitam a sustentação da implementação de novas estratégias globais, introduzindo ao ambiente organizacional o desenvolvimento tecnológico, os conceitos de globalização dos sistemas de comercialização e do sistema produtivo, forte acesso à informação e a adoção de estruturas de aprendizagem.

Com o objetivo de oferecer produtos ou serviços com forte valor agregado, valoriza-se o funcionário que seja empreendedor e com perfil autônomo para gerar respostas rápidas, e comprometido com a organização e com a sua própria competitividade profissional. Há uma crença de que o desenvolvimento individual favorece o desenvolvimento organizacional, assim as competências organizacionais orientam as competências humanas e estas, por sua vez, subsidiam o desenvolvimento profissional. Com base na aprendizagem contínua, o desenvolvimento profissional retro-alimenta as competências organizacionais.

Para definir sua estratégia e garantir sua competitividade, um passo inicial que uma empresa deve dar é conhecer o público que quer atingir e suas necessidades, e segundo é poder avaliar a capacidade da empresa de atender seus clientes. Define-se a estratégia da empresa a partir do seu tipo de negócio, visando inovação em produto, excelência operacional de modo a oferecer um produto que otimize a relação qualidade/preço e na orientação para serviços com soluções específicas para cada cliente, especializando-se em satisfazer ou até em antecipar as necessidades dos clientes, em virtude de sua proximidade com eles.

Torna-se importante verificar que Hamel e Prahalad (1995) trouxeram o conceito de “core competencies" ou competências essenciais, como aquelas que são identificadas pelo cliente como um real diferencial que a organização oferece, aquelas que são difíceis de serem imitadas por concorrentes e aquelas que podem ser aplicadas ou estendidas às mais diversas localidades, provendo acesso a diferentes mercados. Essa visão das competências essenciais insere a possibilidade de uma combinação que a empresa pode proceder, de modo inteligente, para que possa desenhar, produzir e distribuir produtos ou serviços conforme o desejo do cliente. As competências essenciais podem alterar a forma de uma empresa atuar dando-lhe mais ou menos força para inovar, perder ou estar em melhor posição.

Compreende-se que a competência essencial não se refere necessariamente ao uso de tecnologia. Pode ser um conhecimento do mercado, a ação de um departamento de marketing, uma necessidade contingencial ou uma logística de distribuição adotada, sendo que cada uma 
dessas competências está envolvida com um processo de aprendizagem promovendo pesquisas, estímulos à criatividade, inovação e capacitação dos recursos humanos.

Zarifian (2001) diferencia essas competências em uma classificação que permite uma correlação da formação de competências para atender as estratégias adotadas pela organização. É possível fazer uma avaliação interna e verificar quais competências devem ser desenvolvidas e qual aprendizagem será necessária. Assim uma empresa se diferencia pelas seguintes competências: conhecer tudo sobre o processo de trabalho, conhecer especificamente o trabalho a ser realizado e ter conhecimento técnico para tal, saber organizar os fluxos de trabalho que refletem o operacional da organização, aliar competência técnica ao serviço impactante que será oferecido ao consumidor final e saber ser, sustentando o comportamento das pessoas. O estímulo ao desenvolvimento das pessoas refere-se à autonomia, responsabilização e comunicação. A percepção da comunicação é um componente essencial do trabalho.

É na qualidade das interações e na comunicação no interior de uma equipe de trabalho que se assenta o desempenho das organizações. Para Zarifian (2001:26) "a qualidade da comunicação é onipresente: está presente nos diálogos e cooperação com os clientes-usuários e nos processos de ação que as diferentes categorias de assalariados devem executar em conjunto; está presente nas análises a posteriori dos efeitos úteis e nas avaliações críticas da qualidade do serviço efetivamente oferecido e está presente nas pesquisas para melhoria e inovação".

A materialidade do trabalho moderno incorporou o conceito de serviço, de prestar um serviço para um usuário real. A produtividade do funcionário está na compreensão dos problemas específicos do cliente, de escutar e entender no sentido adequado da solução que a empresa propõe ao cliente. A avaliação da produtividade não pode ser automática, não pode ser apenas de um investimento mensal e conta com a participação e a avaliação do cliente. Em condições de mutações no trabalho, a rotina perde sentido com a tecnologia da informatização de processos mais repetitivos e uma nova complexidade encadeia trabalho, produção e necessidade de novos conhecimentos.

Um serviço, um contrato, um cenário pode sofrer intervenção de novos eventos, a qualquer instante e a empresa e seus funcionários devem se preparar para o novo, para o que não estava programado. Uma empresa existe quando tem um cliente para seu produto e trabalhar é gerar um serviço. É o usuário que dá sentido à qualidade final do serviço prestado. Neste contexto torna-se um componente essencial do trabalho, a comunicação. 
A qualidade do trabalho depende da interação da equipe de trabalho entre as várias áreas, do contato com o cliente e implica em compromisso com o sucesso de ações que envolvem esse conjunto. Surge a necessidade de novos vínculos profissionais que têm como base a flexibilidade, a troca de informações, a necessidade de se falar, de trocar conhecimentos, de conhecer expectativas, de interpretar as idéias do cliente e de apresentar respostas.

\subsection{4- Modelo de Gestão de Pessoas Baseado em Competências}

Em tempos menos turbulentos a gestão de pessoas esteve centrada em definir cargos e salários e preencher os cargos vagos com ocupantes selecionados. Nesse sentido as pessoas e os cargos e salários eram tratados sob aspecto operacional e muito pouco sob o foco estratégico. Para Fischer (2002:12), “o modelo de gestão de pessoas é a maneira pela qual a empresa se organiza para gerenciar e orientar o comportamento humano no trabalho". É considerado como característica da gestão de pessoas nos dias de hoje, o foco centrado nas pessoas e suas competências para fazer a diferença na estratégia de competitividade adotada pela organização. Gestão de Pessoas é apresentada por Dutra (2002) como um conjunto de políticas e práticas que permite a conciliação de expectativas entre a organização e as pessoas para que ambas possam realizá-las ao longo do tempo. Entende-se que um modelo deva apresentar conceitos e servir como referencial para a compreensão da realidade organizacional, facilitar as ações gerenciais e permitir um aprimoramento contínuo de processos de trabalho e de desenvolvimento de seus profissionais. Para Fischer (2002:17), “compõem o modelo de gestão: princípios, orientação de valor e crenças básicas, políticas, diretrizes de ação, que traduzam compromissos da organização com objetivos de médio e longo prazos para gestão de pessoas e processos e cursos de ação previamente determinados e operacionalizados por ferramentas de gestão".

No modelo de Gestão de Pessoas as políticas adotadas pelas empresas refletem a valorização dos talentos humanos, a atração e manutenção de pessoas de alto potencial, condições favoráveis à motivação, possibilidades de crescimento funcional e profissional, incentivos vinculados aos resultados e à necessidade de Políticas de Recursos Humanos adaptadas à realidade da empresa e ao contexto econômico-social.

Quando baseado em competências, o modelo de Gestão de Pessoas facilita o mapeamento de competências necessárias a uma empresa e deve estar alinhado às 
capacidades de pensar, sentir e agir que são exigidas daqueles no exercício de um cargo. Como estratégia de negócio, quando as empresas identificam suas “competências essenciais" e efetuam um inventário das competências presentes nos seus funcionários, torna-se interessante que as empresas definam competências técnicas e específicas requeridas na ocupação dos cargos e que elas sejam transparentes aos profissionais, como uma condição de busca para o autodesenvolvimento.

A gestão de pessoas baseada em competência pode favorecer e facilitar, por meio de suas políticas, o reconhecimento das pessoas como fator essencial para o alcance da excelência operacional. Sob a ótica de sua subjetividade, elas são consideradas como talentos, a partir de olhares diversos que influenciam nos processos da melhoria organizacional. O homem deixou de ser valorizado como "mão-de-obra" e passou a ser valorizado como "mente-de-obra", por funções que a máquina não pode suprir: conhecer, intuir e criar para atingir resultados e agregar valor ao produto/serviço oferecido ao cliente.

O modelo de Gestão de Pessoas na era da competitividade é resultado da modificação de paradigmas que transforma os recursos humanos em parceiros da organização, pessoas com competências para um trabalho que ganha novo significado. Adotar o modelo de gestão de pessoas implica em reconhecer que a empresa não tem como criar unilateralmente um sistema capaz de definir o comportamento humano a ser seguido no trabalho, mas pode propor um modelo no sentido de estimular determinadas posturas e ações desejadas. Comportamentos podem ser estimulados e geridos, mas dificilmente administrados pela organização com base numa ação gerencial de planejar, organizar, dirigir e controlar e somente os próprios indivíduos é que podem produzir suas atitudes e comportamentos. Verifica-se, portanto, que depende da vontade das pessoas compreenderem sua participação no processo, poderem sentir e agir.

Se a meta da gestão de pessoas é o reconhecimento da importância do fator humano, então do homem se espera desenvolvimento de idéias e ações coerentes. A sociedade vive um momento de tensão emocional, muitos são os males e poucas as soluções. Discute-se, portanto, como realizar essa meta se não com a efetiva participação das pessoas. Torna-se necessário tirar da interioridade do ser a coragem e a vontade de agir com novos modelos mentais que vão além do "CHA", emprestado de livros, aulas e consultas, pois se trata da internalização ou interiorização desses saberes acessados, que transformados servem de bússola para novas ações. 


\section{6- Comunicação e Organizações}

Muitas vezes a comunicação tem sido usada na organização sob um caráter de “curinga", pois há uma real confusão nos níveis teóricos e práticos quanto essa relação entre a organização e a comunicação. Neste contexto questiona-se se é a organização que determina um tipo ou fluxo de comunicação ou o contrário, se é a comunicação que molda a natureza da organização; se a estrutura organizacional que condiciona o fluxo das mensagens ou se são os padrões de comunicação que desenvolvem as estruturas e moldam o tipo de coordenação de tarefas, e ainda, como efetivamente o contexto organizacional afeta a comunicação ou observando-se de outro lado, como a comunicação molda o contexto organizacional.

Neste trabalho considera-se que a comunicação e organização podem produzir--se uma à outra. Há uma equivalência, mas não se pode radicalizar e tratar a organização e a comunicação como uma só entidade; representam os mesmos conceitos, mas expressos de modo diferentes. O dilema sobre a relação organizacional e a comunicação tem gerado muitos estudos e merece destaque a pesquisa de Morgan (2000), pautada nas metáforas que são utilizadas para descrever as organizações. No estudo baseado nas metáforas a organização é colocada em primeiro plano e a comunicação é colocada na posição de fundo. Por outro lado se a teoria comunicacional for considerada como central e equivalente ao ato de organização, podem surgir novas metáforas que representem a relação organização e comunicação, neste caso a comunicação é produtora das organizações. As metáforas revelam modos alternativos de pensar sobre a origem e a natureza do ato de organização, seus processos e conceitos, que formam suas raízes e seu modo de existir.

\subsection{1- Metáforas da Comunicação e Organização}

O termo comunicação é onipresente nas organizações e conforme o texto Metáforas da Comunicação e da Organização, Putnam, Phillips e Chapman (2004), a comunicação sempre foi tratada ao longo da história da administração pelos teóricos clássicos e por teóricos organizacionais. Nos estudos das organizações o sentido de comunicação torna-se ardilosamente impreciso. Para os teóricos clássicos há uma visão da comunicação enquanto uma informação, mensagem ou canal. Para os teóricos mais contemporâneos é apresentada como sinônimo de constructos. O Quadro IV apresenta uma adaptação das referências à comunicação, tratada por teóricos clássicos e contemporâneos, ao longo dos anos. 
Quadro IV - Concepção Teórica, Clássica e Contemporânea da Comunicação

\begin{tabular}{|c|c|c|c|c|c|}
\hline \multirow{6}{*}{$\begin{array}{l}\text { Teóricos } \\
\text { Clássicos }\end{array}$} & Weber (1947) & $\begin{array}{l}\text { Documentos } \\
\text { escritos e } \\
\text { associados à } \\
\text { autoridade de } \\
\text { comando. }\end{array}$ & \multirow{6}{*}{$\begin{array}{c}\text { Teóricos } \\
\text { Contemporâneos }\end{array}$} & $\begin{array}{l}\text { Galbraith } \\
\text { (1973) }\end{array}$ & $\begin{array}{l}\text { Processamento de } \\
\text { informações }\end{array}$ \\
\hline & Taylor (1947) & $\begin{array}{c}\text { Fluxo ascendente } \\
\text { de mensagens e ao } \\
\text { ato de persuadir os } \\
\text { trabalhadores }\end{array}$ & & $\begin{array}{l}\text { Rogers e } \\
\text { Kincaid } \\
(1981)\end{array}$ & Redes Sociais \\
\hline & Fayol (1949) & $\begin{array}{l}\text { Fluxo horizontal da } \\
\text { informação. }\end{array}$ & & $\begin{array}{c}\text { Tichy e } \\
\text { Fombrun } \\
(1979) \\
\end{array}$ & \multirow[t]{2}{*}{ Coordenação } \\
\hline & $\begin{array}{c}\text { Roethlisberger } \\
(1941)\end{array}$ & $\begin{array}{l}\text { Comunicação } \\
\text { informal e ouvir. }\end{array}$ & & Hage (1974) & \\
\hline & Follet (1947) & $\begin{array}{c}\text { Feedback e } \\
\text { comportamento } \\
\text { circular }\end{array}$ & & Likert (1967) & \multirow[b]{2}{*}{ Participação } \\
\hline & Simon (1957) & $\begin{array}{l}\text { Premissas de } \\
\text { decisão. }\end{array}$ & & $\begin{array}{l}\text { Miller e } \\
\text { Monge } \\
\text { (1986) }\end{array}$ & \\
\hline
\end{tabular}

Fonte: Putnam, Phillips e Chapman, 2004 (adaptado)

Tomando como base o estudo de Putnam, Phillips e Chapman (2004), verifica-se então que dois interesses dominaram as pesquisas: a habilidade do indivíduo para ser mais eficiente na comunicação e no seu trabalho e os fatores que caracterizavam a eficiência da comunicação no sistema inteiro. Esse é um período considerado de orientação modernista e a esse período corresponde também aos estudos psicológicos que focalizavam a necessidade da interação superior e subordinado, o clima da comunicação, o processamento da informação. Nesse mesmo período a sociologia contribui com estudos referentes às redes de comunicação, coordenação de grupos de trabalhos e novas tecnologias de comunicação. Portanto, nesta visão, as organizações são caracterizadas como entidades racionais e instrumentais e a comunicação incorpora um papel puramente utilitarista ou instrumental.

A história e desenvolvimento da pesquisa em comunicação organizacional refletem os interesses em comunicação empresarial e individual dos anos 1920 a 1950 e a influência da escola de relações humanas, dos anos 1950 até 1970. O quadro V especifica essas tendências. 
Quadro V - Interesses Históricos em Comunicação Organizacional

\begin{tabular}{|c|c|}
\hline PERÍODO & COMUNICAÇÃO \\
\hline $1920-1950$ & Comunicação empresarial e industrial \\
\hline $1950-1970$ & Influência Escola Relações Humanas. \\
\hline $1960-1970$ & $\begin{array}{l}\text { Estudo das mensagens que fluíam nas organizações e do modo como o clima comunicacional } \\
\text { influenciava a adequação e eficiência das transmissões das mensagens. }\end{array}$ \\
\hline 1985 & $\begin{array}{l}1985 \text { Dale Carnigie e a retórica empresarial, ênfase na estratégia de persuasão a serviço do } \\
\text { alto escalão gerencial, na precisão e elegibilidade dos relatórios e, na eficiência dos diferentes } \\
\text { meios de comunicação (Putnam, Cheney e Redding 1985). }\end{array}$ \\
\hline
\end{tabular}

Fonte: Adaptado a partir de Putnam, Phillips e Chapman (2004)

A partir desse estudo de Putnam, Phillips e Chapman (2004) verifica-se que na década de 1980 há uma reviravolta no conhecimento acadêmico da comunicação organizacional. Revela-se a ausência de uma estrutura teórica e a natureza da realidade organizacional imersa no trabalho modernista, enquanto a comunicação é vista como uma transmissão linear, definida como estudo da mensagem, informação, significado e da atividade simbólica. Esse movimento abre espaço para novos campos de pesquisa: o sentido dos eventos organizacionais, a ambigüidade estratégica, a cultura organizacional, a identificação organizacional, as regras e scripts da comunicação, o discurso corporativo e o exercício do poder e controle por meio da comunicação distorcida. Duas principais correntes orientaram os estudiosos em comunicação nas interpretações da vida organizacional:

- Naturalista - Interpretações fundadas no contexto e na situação. Postura pluralista ao enxergar a vida organizacional além da perspectiva administrativa.

- Crítica - Ao final de 1980 surgiu a perspectiva construtivista social, centrando-se no poder e no controle. Verifica-se a presença de grupos dominantes e processos de comunicação organizacional que não são considerados neutros. O discurso e as ações simbólicas eram os modos pelos quais a ideologia de controle se tornou natural e legítima nas organizações.

A pesquisa de comunicação organizacional trouxe à tona uma falha por não perceber as maneiras sutis e complexas pelas quais a comunicação e a organização são interrelacionadas. Essas correntes não investigaram o que é comunicação nem como ela opera enquanto se organiza. Nesse período o estudo das metáforas ganhou espaço no campo da pesquisa comunicacional, pois revelou diversas representações de comunicação e da organização e o objetivo era fornecer insights sobre como se entendia a vida organizacional, no sentido de facilitar a interpretação da realidade social. As metáforas delineiam a maneira 
como as pessoas vêem o mundo e como elas lhe atribuem sentido, isso implica conhecimento sobre percepção, conceituação e entendimento de uma coisa à luz de outra. O estudo sobre metáforas mais citado é de Morgan, desenvolvido em 1986 e intitulado Imagens da Organização.

Sob uma outra ótica verifica-se que Putnam, Phillips e Chapman (2004), põem em xeque as metáforas tradicionais para delinear os estudos das organizações e exploram novas facetas das relações entre a comunicação e a organização. Estas novas formas de se ver a organização tomam a comunicação como figura e a organização como fundo. Eles apontaram as metáforas alternativas que existem no espaço entre figura e fundo, de modo que se distanciaram das metáforas universais, como a da máquina e a do organismo, consideradas pedras angulares da teoria organizacional. Os autores também observam como principal fraqueza da análise metafórica tradicional, "a tendência de trancar as categorias dentro de significados e relações fixas" e para se apoiar na análise metafórica tradicional tentam evitar o congelamento das relações metafóricas. Eles buscam rastrear as cadeias de metáforas e identificam assim sete linhas metafóricas, conforme Quadro VI a seguir, que apresenta uma adaptação das linhas que guiam os programas de pesquisa em comunicação.

Quadro VI - Programas de Pesquisa em Comunicação

\begin{tabular}{|c|l|l|}
\hline Metáfora & Refere-se & Entendimento de Comunicação \\
\hline Conduíte & Encaminhamento da Comunicação & Transmissão \\
\hline Lente & $\begin{array}{l}\text { Organizações como sistemas perceptuais ou } \\
\text { olhos, que lêem ambientes, disseminam } \\
\text { inovação e mudança. }\end{array}$ & É filtrada e distorcida \\
\hline Linkage & $\begin{array}{l}\text { Organização como rede ou sistema de } \\
\text { indivíduos interconectado. }\end{array}$ & $\begin{array}{l}\text { Age para conectar: teia, ponte, contrato, } \\
\text { relacionamentos. }\end{array}$ \\
\hline Símbolo & $\begin{array}{l}\text { Traços mais importantes do significado, da } \\
\text { interpretação e do entendimento da natureza da } \\
\text { organização. }\end{array}$ & $\begin{array}{l}\text { Interação social e desempenho nos papéis } \\
\text { administrativos. }\end{array}$ \\
\hline Vultura organizacional e seus artefatos & $\begin{array}{l}\text { Interpretação de formas literárias: narrações, } \\
\text { metáforas, ritos, rituais e paradoxos. }\end{array}$ \\
\hline Discurso & $\begin{array}{l}\text { Vozes da dominação por meio da ideologia e } \\
\text { do controle suave. Práticas participativas e e } \\
\text { democráticas. Organização torna-se um coro } \\
\text { de vnzes ahafadas }\end{array}$ & $\begin{array}{l}\text { Ideologia política da administração. } \\
\text { Exganizações aparecem como textos que supressão de conflitos. } \\
\text { consistem em gêneros e diálogos. }\end{array}$ \\
\hline
\end{tabular}

Fonte: Adaptado a partir de Putnam, Phillips e Chapman (2004) 
O que se verifica é que essas metáforas podem trazer novos insights acerca de como organizar a comunicação. No "conduíte" entende-se que os receptores são passivos ou reativos e a imagem da comunicação é a metáfora da ferramenta: comunicação como um instrumento para fins organizacionais.

$\mathrm{Na}$ "lente" ela confia na transmissão da comunicação e está enraizada na transferência de idéias. A imagem é olho, visão, percepção com capacidade de organizar, alterar a maneira como a informação é percebida.

$\mathrm{Na}$ "linkage" o foco é a conexão que une pessoas e as redes de relacionamento, mostra como a relação entre comunicação e a organização ocorre no sentido de gerar produtividade e aproximação entre os membros do grupo. Esses laços fortes indicam que indivíduos sofrerão maior pressão para adotar normas, valores e expectativas diferentemente dos empregados com vínculo mais frouxo. Os laços fracos mantêm a estabilidade da organização e ajudam-na a se adaptar às mudanças ambientais.

A "performance" refere-se ao processo e à atividade, não à produtividade. A comunicação produz as organizações e as organizações produzem a comunicação. Trata-se de uma visão interativa de comunicação organizacional.

Nos "símbolos" a comunicação é interpretação e são eles que dão sentido ao mundo da comunicação como processo de representação, para acentuar a identificação organizacional e os compromissos interpessoais. Os símbolos permitem a abstração e neste grupo os paradoxos focalizam relacionamentos entre mensagens e não são os sentidos de um símbolo particular.

$\mathrm{Na}$ "voz" o papel da corporação na sociedade moderna, segundo Deetz apud Putnam, Phillips e Chapman (2004), esclarece como a ideologia política da administração tornou-se hegemônica, no sentido de que nenhuma outra solução para os problemas organizacionais parece convincente. O que se observa nessa metáfora é que a grande empresa, como instituição social, continua a predominar sobre as atividades tradicionalmente organizadas de outras maneiras. As grandes sociedades anônimas e corporações controlam tudo, desde a identidade pessoal até o uso de recursos naturais ou ainda, as definições de valores e distribuição de bens e serviços. As vozes podem ser ouvidas, mas são distorcidas ou dominadas e novas vozes podem ser adicionadas para mudar as assimetrias, mas o resultado é a reprodução dessas assimetrias. 
No "discurso", a linguagem se expressa também como diálogo, que luta por um equilíbrio entre a autonomia individual e as restrições organizacionais, considerando a incorporação de diversas vozes. Entende-se que o diálogo pode transformar ações e promover o aprendizado organizacional pelo desenvolvimento de sinergia, empatia e deliberação entre indivíduos.

Neste sentido a visão dos três autores ecoa como um apelo para mover a teoria organizacional no sentido das metáforas discursivas. Observa-se que a metáfora do discurso se baseia em três elementos: mensagens, significado e contexto. Cada metáfora acrescenta novas possibilidades para os estudos organizacionais e para reflexão e pesquisa. A principal implicação é que o campo da comunicação organizacional enfrenta uma crise de representação. A comunicação não espelha mais a realidade, mas é formativa, no sentido de criar e representar o processo embutido no ato de organizar. Essa crise pode também ficar evidente na fluidez de novas formas de organização, nas alianças, nas fusões, etc. ou quando organizações são descentralizadas em atividades, que cruzam fronteiras e abraçam a diversidade. Quando se aceita as imagens das organizações em primeiro plano deve-se compreender que elas são fragmentadas e caracterizadas pelas contradições de um mundo em transformação.

\subsection{2- Aspectos Relacionais da Comunicação}

A comunicação como competência tem como característica permitir um elo, uma espécie de conversação, entre comunicação e organização sugerindo uma alternativa viável para a re-elaboração das teorias organizacionais. Entende-se que a realidade organizacional pode ser determinada em parte pela percepção e perspectivas que se traça com relação à realidade e não pelos fenômenos que se observa, o que enfatiza a necessidade de se buscar novas perspectivas no ato de organizar o trabalho e as empresas, com apoio da comunicação.

Krone, Jablin e Putnam (1982) enfatizam a importância do claro reconhecimento de que a maneira como a perspectiva de comunicação humana ocorre, afeta os estudos de comunicação organizacional. Portanto, as questões que pesquisadores da comunicação organizacional escolhem para pesquisar e o método que utilizam na interpretação de dados são diretamente resultantes das perspectivas que cada um utiliza para visualizar a comunicação humana: perspectivas mecanicistas, psicológicas, simbólicas e as caracterizadas 
como sistemas de interação. Assim o lócus da comunicação depende da posição que se utiliza para olhar a comunicação, ao invés de explicar o processo de comunicação.

A perspectiva mecanicista enxerga o processo de transmissão da mensagem que vai de um ponto até um outro. Então o que importa na comunicação é o canal que interliga os comunicadores. Trata-se de uma visão mais reducionista, identificando e medindo as partes e então testando as cadeias de causas lineares entre as partes. Nesse sentido aplica-se a metáfora do conduíte, que foca o canal ou o veículo para transmitir mensagens. Essa perspectiva mecanicista da comunicação organizacional lhe confere a função de transmitir as informações por parte da companhia aos empregados ou por parte dos superiores aos subordinados.

$\mathrm{Na}$ perspectiva psicológica os estudos focam em "como" as características dos indivíduos afetam a sua comunicação. Então o conceito de filtro é visto como a chave para as percepções, conhecimento e atitudes dos indivíduos, que atuam para estruturar um campo de estímulos potencialmente caótico. Trata-se também de um foco de causalidade linear, as funções comunicativas revelam uma transitividade e o reducionismo caracteriza o processo de transmissão organizacional, no nível de análise intrapessoal. Trata-se de uma perspectiva na qual o conceito de filtro é algo interno ao indivíduo, portanto não observável, como se tratasse de uma verdadeira "caixa preta". As explicações de conceitos de comunicação são restritas para observações diretas de entradas e saídas de informação, que revelam a adaptação dos empregados ao contexto.

A perspectiva simbólico-interpretativa abordada por Krone, Jablin e Putnam (1982) adota a visão da comunicação humana que reflete um interacionismo simbólico, pois considera o ser, os pensamentos compartilhados e o comportamento social decorrente. $\mathrm{O}$ lócus da comunicação nesta perspectiva está no compartilhamento e na compreensão através do relacionamento empático com o outro. Assim os padrões das atividades coordenadas criam, mantém e dissolvem organizações. O indivíduo responde para o outro baseado em significados compartilhados, expressos em palavras e ações. Estes significados são derivados simbolicamente da troca mútua de experiências e negociações consensuais, que são desenvolvidas na cultura organizacional. A cultura é considerada pelos autores como "o que uma organização é ao invés do que ela tem”. Entende-se que essa visão trata a comunicação como ato de participação e as pesquisas nessa área devem verificar a visão dos participantes.

A perspectiva de sistema de interação baseia-se na análise de padrões seqüenciais de comportamento e trata a comunicação como um sistema de envolvimento, tem foco nos tipos 
seqüenciais de mensagem e comportamento e utiliza conceitos de comportamento verbais e não verbais que se revelam em decorrências de atos e ações afetados pelas contingências.

Assim as quatro perspectivas permitem que o pesquisador examine o mesmo conceito sobre quatro óticas e no tipo de questionamento que elas geram para a investigação escolhida. Entende-se que a visão de comunicação adotada por uma organização é o que molda a forma como as pessoas vêem a comunicação organizacional e o modo como elas interpretam o que elas vêem. São essas interpretações que orientam as relações dentro das organizações. Nenhuma das perspectivas é a mais correta ou errada, pois a comunicação transita por todas elas.

A comunicação organizacional se apresenta como disciplina que cresceu muito no final do século XX, mas que em paralelo teve que lutar muito para estabelecer uma clara identidade para o campo. Baseando-se no Novo Manual de Comunicação Organizacional: Avanços na Teoria, Pesquisas e Métodos, cujos editores são Frederic M. Jablim e Linda L. Putnam (2000), acrescentam-se a contribuição de Tompkins e Wanca - Thibault (2000), que apresentam um histórico das ideologias que identificam o campo de estudo da comunicação organizacional, nas décadas de 1940 até em meados de 1970.

Algumas questões em pesquisa foram consideradas predominantes e no período de 1940 incluíram estudos sobre os efeitos que teve a comunicação de massa sobre os empregados e o questionamento estava na confirmação de que um empregado informado seria um empregado mais produtivo.

Em 1950 questionava-se como a comunicação de pequenos grupos afetava a performance organizacional e modificava as atitudes e comportamentos de seus membros, como redes de comunicação organizacional podem ser medidas, como o relacionamento entre os membros, as atitudes e as percepções do comportamento na comunicação afetam sua performance no trabalho, qual a correlação entre atitudes, a performance e feedback aos trabalhadores e ainda, se a informação traz satisfação no trabalho.

No período dos anos de 1960 predominaram temas como: os empregados percebem a importância da comunicação para o perfil do "bom supervisor", grau de compreensão entre superior e subordinado pode distanciar as pessoas quanto aos problemas na organização, qual a relação entre atitudes e produtividade dos subordinados e ainda, a extensão do que eles percebem e a forma como eles participam da tomada de decisão. 
Nos anos de 1970 pesquisou-se mais sobre quais são os componentes e correlatos do superior com o subordinado, grupo de trabalho e clima da comunicação organizacional. E ainda, quais são as características de uma rede de comunicação organizacional e grupos de trabalho.

Uma questão fundamental que se apresenta está centrada no que as pessoas vêem ou o que elas são capazes de fazer quando se pensa a comunicação de uma forma ou de outra. Conforme Deetz (2000) uma revisão de estudos mais relevantes se faz necessária para misturar-se às características de interações complexas que marcam os espaços de trabalho contemporâneos. Três formas bem diferentes de conceituar a comunicação organizacional orientam as pesquisas. O primeiro enfoque estaria no desenvolvimento da comunicação organizacional como uma especialidade em departamentos de comunicação e associações de comunicação. Destas revisões é possível obter maior compreensão sobre pessoas, seus relacionamentos e políticas das universidades que desenvolvem suas pesquisas na área, do que sobre conceito de organização e comunicação.

O segundo enfoque para conceituar comunicação organizacional aponta a comunicação como um fenômeno que existe nas organizações. Muitos desses estudos negam que um fenômeno único exista e a comunicação organizacional não é considerada um fenômeno com muitas explicações.

Um terceiro enfoque para apresentar o conceito é pensar a comunicação como um modo de descrever e explicar as organizações. A teoria das comunicações pode ser utilizada para explicar sobre a produção das estruturas sociais, estados psicológicos, categorias de seus membros, conhecimento, ou ainda, como um fenômeno, entre tantos outros na organização. O foco estaria no processo de organização através da interação simbólica, ao invés da comunicação como parte da organização. Pesquisadores nos últimos anos têm focado nas organizações como formações discursivas complexas, nas quais as práticas discursivas estão em ambas, "na" organização e nas produzidas por elas. Nessa visão a pesquisa literária revela a importância de se dar atenção aos que estudam a comunicação e também àqueles que participam "na" organização, homens, mulheres, trabalhadores em geral, ocupantes de cargos gerenciais que produzem fenômenos no mundo das organizações, tais como comunicação, necessidades, motivações, informações, além de gerar lucros.

$\mathrm{Na}$ linha da teoria do discurso moderno, a linguagem é o centro do processo de constituição do mundo externo, que é considerado ambíguo e indeterminado e que se transforma diante de propósitos específicos. Trata-se de uma meta-perspectiva para a 
comunicação entender como os diferentes grupos embutem nos seus discursos os sinais de como eles percebem, pensam e falam sobre a vida organizacional.

Um olhar mais contemporâneo para alternativas nos programas de pesquisa na comunicação pode ser a ênfase no que foi conceituado anteriormente como discurso e mais tarde, como um ensaio para proposição de pesquisas nas linhas normativa, interpretativa, crítica e dialógica.

Para Geertz (2000), essas divisões e áreas de estudo são interessantes e representam modos de pensar o campo de estudo que são mais comuns. Estes enfoques originaram-se do processo de discurso, tratando-os como naturais e não produzidos, escondendo valores e suposições e repudiando casos específicos e particularidades de estudos de comunicação. Estas particularidades devem ser apontadas:

A) A orientação por tópicos não é uma ferramenta neutra de classificação porque dá uma orientação atomística do mundo e estudos hoje se baseiam na visão holística da ciência e trazem temas como cultura, pesquisas etnográficas que apontam para atividades e estruturas organizacionais como canais e relacionamento interpessoal. Pesquisadores etnográficos não estudam tópicos, eles estudam particularidades específicas.

B) O esquema de reunião de dados molda as revisões futuras, por exemplo, os dados podem estar limitados por um estudo publicado em um jornal de comunicação e seus exemplares. Assim trabalhos conceituais que geralmente apresentam um grande impacto sobre o campo de estudo e de prática, tendem a ser deixado de lado. A tendência é sair dos tópicos e focar mais nas diferenças epistemológicas ou metodológicas.

$\mathrm{Na}$ visão do autor os estudos apresentam diferenças mostradas pelos contrastes entre o "local/emergente" e "elite/priori”, que focam na origem dos conceitos e nas afirmações dos problemas como parte constituinte do processo em verificação. Compreende-se que o pólo "local/emergente" dá atenção aos sistemas de linguagem aberta e produz uma forma de conhecimento caracterizada mais pelo insight dentro de eventos empíricos do que por generalizações empíricas de larga escala. A dimensão “elite/priori” privilegia sistemas particulares de linguagem e especialidade da comunidade investigada, com base na origem dos conceitos e problemas e focando nessas dimensões. Três ganhos são importantes: reconhece-se o construtivismo social e lingüístico e os conceitos são usados na produção do objetivo e determinação do que é o problema; o foco na origem dos conceitos ajuda distinguir espécies fundamentalmente diferentes de conhecimentos e a dimensão ajuda a lembrar que 
ambas a aplicação e a descoberta dos conceitos podem demonstrar, implícita ou explicitamente, alianças políticas com diferentes grupos na organização ou sociedade, em um sentido mais amplo.

As orientações podem ser contrastantes na medida em que são trabalhadas dentro de um conjunto de estrutura do conhecimento dominante, relações sociais e identidades chamadas de discurso de "consenso" e uma outra chamada de discurso do "dissenso" que trabalha com a ruptura dessas estruturas. A dimensão do "consenso/ dissenso" fornece elementos para se compreender a relação da pesquisa com a ordem social vigente. "Consenso e dissenso" referem-se a acordos e desacordos ao invés de uma apresentação de unidade ou diferença, continuidade ou descontinuidade que prevalecem nos discursos. O pólo do "consenso" aponta para o caminho que algumas pesquisas tendem para buscar ordem e tratar a produção da ordem, como um traço dominante ao sistema social. O pólo do "dissenso" considera "estrangulações" como estado natural de ser. Estas diferenças podem ser caracterizadas claramente em abstração em um contínuo de tempo, cada consenso atinge um auge e depois uma queda para "dissenso" e cada "dissenso" faz emergir um "consenso".

As dimensões focam na relação das práticas de pesquisa do discurso social dominante dentro de uma organização ou comunidade estudada. Essa dimensão pode ser caracterizada por esses pares de concepção.

No modelo tradicional de organização os processos estão centrados na questão econômica e a comunicação auxilia nas realizações econômicas. Parece que se a comunicação baseada na tomada de decisão pudesse ser um cálculo econômico, então ela seria. Em um modelo baseado nos Stakeholders são muitas as metas e para Geertz (2000) a interação entre os Stakeholders pode ser concebida como um processo de negociação auxiliando em metas mútuas de realizações. Assim é a comunicação que pode dar sentido à condição de negociação. Concepções de interação humana, negociação e racionalidade, desenvolvidas por teóricos da comunicação são perfeitas para essas novas necessidades. Para uma completa contribuição os pesquisadores de comunicação organizacional precisariam usar conceitos de comunicação dirigidos ao crescimento da participação genuína ao invés da influência crescente e do controle. Esta é uma mudança que ainda está incompleta. 


\subsection{3- Perspectivas de Mudanças na Comunicação}

Diante da complexidade da vida organizacional, verifica-se que ela não escapa da vinculação com seu meio ambiente, dos aspectos econômicos, políticos, tecnológicos, ecológicos, culturais que a circundam. Essa complexidade aumenta na medida em que as pessoas têm conhecimentos e formas diferenciadas de pensar, sentir e agir; elas têm maneira própria de enxergar a realidade e nem sempre o que elas comunicam está sendo assimilado pelos outros da mesma forma. Assim, questões organizacionais exigem das pessoas uma visão mais crítica para equacionar os problemas e saber lidar com eles. Para que as pessoas possam aprender, rever conceitos e promover a viabilidade pessoal e organizacional, elas devem entender que a comunicação, através da linguagem faz diferença na vida das pessoas, disse o poeta Fernando Flores “... com ela inventamos mundos com outras pessoas".

$\mathrm{Na}$ visão de Souza Filho (2002), a comunicação e a interdisciplinaridade se constituem num tema que está sob a mira e é responsabilidade de todos. Esse é um tempo para pensar nessa interdependência. Um novo tempo requer que as pessoas estejam atentas aos acontecimentos políticos, econômicos e sociais. Para Kunsch (2003:161) "comunicação é um ato de comunhão de idéias e o estabelecimento de um diálogo. Não é simplesmente uma transmissão de informações. A eficácia da comunicação passa pela valorização das pessoas como indivíduos e cidadãos. Os gestores da comunicação devem desenvolver uma atitude positiva em relação à comunicação, valorizar a cultura organizacional e o papel da comunicação nos processos de gestão participativa. Devem planejar conscientemente para comunicação e desenvolver confiança entre emissores e receptores"

O ato de comunicar-se tem uma dimensão completa, não é suficiente dizer que é um compartilhar de um código comum, como a clássica definição. Assim como nas empresas não basta trabalhar a elaboração de revista, quadros ou boletins.

Um primeiro passo para converter a comunicação como um modo de encarar a vida ou as idéias é reconhecer que a comunicação não é uma função da área de comunicação, de RH, da direção ou de uma prestadora de serviços. Comunicação é responsabilidade da organização e nesse sentido é de responsabilidade de todos os membros da organização. A idéia é que pouco a pouco se transforme em algo menos controlável ou controlador e mais uma ação consciente, cientificamente falando. Trata-se de uma perspectiva para aumentar a convivencialidade e inspirar uma mudança de cultura organizacional. 
As perspectivas de mudanças na comunicação devem fluir no sentido de ajudar as pessoas a enfrentarem mudanças e perceberem a necessidade de desenvolver novas competências: saber se posicionar, fazer projeções e interferir nos rumos dos acontecimentos. É preciso aprender a lidar não com o raciocínio linear, mas a lidar com os efeitos dos atos, que virão na mesma proporção que as causas. Lidar com essa complexidade implica em cuidar das interações e procurar conviver com os efeitos da complexidade. Para conviver nesse teatro do dia a dia, para cada papel há uma nova emoção e os atores sociais se assustam, se frustram, se revêem em novos papéis. Essa convivência em família, com as organizações das quais cada um faz parte - o país, o meio ambiente, a natureza, indica na maioria das vezes, um sentimento de impotência para tentar influenciar nas situações complexas de dificuldades que todos enfrentam.

Para gerar novas respostas torna-se necessário um aprendizado coletivo, as respostas às crises impostas pela complexidade devem vir do todo e não de partes isoladas. É preciso garantir condições para que as partes revejam ou aprendam mais sobre a forma de comunicar-se.

O espaço de trabalho, herdeiro da razão, foi abalado pelo imponderável e agora mexe com a emoção do ser humano, na visão de Freitas (2006:55), "o ser humano pensa e age construindo, por meio de seus atos, a sua própria realidade social, com autonomia relativa e sabendo o preço que está disposto a pagar no plano social. Como forma de expressão básica recorre à linguagem para expressar sua realidade interior e exterior. Portanto, é na análise de todo documento escrito e de toda palavra pronunciada que vamos encontrar o agir, o pensar e o sentimento dos indivíduos nas organizações. O tema da comunicação deve merecer prioridade entre os especialistas do comportamento organizacional se partirmos de constatações óbvias de que o ser humano é um ser de desejo e pulsão, um ser simbólico e um ser espaço-temporal que, pelas relações mantidas com o outro, realiza jogos de identificação: introspecção, projeção, transferência".

\section{Campo da Comunicação}

Para Baccega (2002) os estudos da comunicação que se preocuparam fundamentalmente com a instituição do pólo da emissão possibilitaram a criação de uma visão dos indivíduos envolvidos como tambores de percussão dos valores dominantes, mas com um ritmo nem sempre como o desejado. Parece que nem sempre os objetivos do emissor eram totalmente atingidos e daí o interesse em ampliar o objeto de estudo da comunicação para o 
receptor. Então a questão do sujeito passa a ser importante para os estudos do processo comunicacional. Nessa contribuição da autora verifica-se que a constituição da subjetividade e o seu estudo são essenciais para a comunicação, pois ela constitui a natureza tanto do “emissor" quanto do "receptor". Como agente que constrói sua própria história, o indivíduo e o seu universo são formados pelo diálogo com seu meio e é como ele reelabora ou reinterpreta aquilo que ouve, lê ou visualiza.

O indivíduo que desenvolve sua interioridade e se relaciona com outros indivíduos, pode definir seus objetivos, hierarquizar necessidades num imenso universo que ele produz e é produto. Para Morin (2000), “Os indivíduos produzem a sociedade, que testemunham o surgimento da cultura, e que retroage sobre os indivíduos pela cultura". Percebe-se então que a subjetividade se manifesta ora na emissão, ora na recepção, resposta da condição em que o sujeito dialoga com o outro. A subjetividade configura-se ao se compreender sobre a existência do outro. Nessa dinâmica de inter-relacionamento o ser se reformula em termos de pensar, sentir e agir conforme seu grupo, sua classe social, seus conhecimentos e da realidade concreta.

No campo da comunicação entende-se que conhecer o indivíduo como ser dialógico, que aprende, ensina e se modifica, torna-se fundamental para se discutir sobre a unidade e a diversidade das linguagens nas organizações sociais e nas culturas.

Para Morin (2001:51), “explicar não basta para compreender. Explicar é utilizar todos os meios objetivos de conhecimento, que são, porém, insuficientes para compreender o ser subjetivo". Os indivíduos e o seu modo de compreender ou de expressar revelam como o “eu” articula estruturas e processos, pois o indivíduo enquanto sujeito dialoga com seu universo.

(...) esfera individual, existe unidade/diversidade genética. Todo ser humano traz geneticamente em si a espécie humana e compreende geneticamente a própria singularidade anatômica e fisiológica. Há unidade/diversidade cerebral, mental, psicológica, efetiva, intelectual e subjetiva: todo ser humano carrega, de modo cerebral, mental, psicológica, efetiva, intelectual e subjetiva, os caracteres fundamentalmente comuns e ao mesmo tempo possui as próprias singularidades cerebrais...". (MORIN 2001:51).

\section{Ciências Sociais e Comunicação}

Considerando que as ciências são produzidas com base em indivíduos/sujeitos, em cuja formação a palavra utilizada carrega a prática social interiorizada, os resultados das produções das ciências sofrerão também a influência da matéria prima utilizada: nas ciências 
sociais, a que se relaciona com a palavra; nas exatas, a que se relaciona com os instrumentos, cuja variação implicará resultados diversos.

Desde o início dos tempos o ser humano se mostrou como uma realidade dinâmica, contraditória e em transformação, portanto uma realidade complexa. As ciências humanas se dedicam às pesquisas sobre os modos de ser do homem, sendo que falta-lhes sempre uma coisa prévia: antes de avaliar o agir de um ser, refletir sobre o próprio ser em sua dimensão antológica. Não é próprio do homem ser passivo, ele tem vontade própria e busca a razão para definir condições ideais de ação. As ciências sociais procuram estudar sobre as condições de uma ação e desligá-la das peculiaridades do ser que age tornou-se algo sem propósito ou razão.

O resultado das produções das ciências sociais ou humanas tem como base o uso da linguagem e o discurso científico pertence ao domínio ao qual a ciência pertence: história, filosofia e física etc. Cada vez mais uma especialidade está menos presa ao seu campo de domínio, mas o que a distingue é o confronto com as demais ciências. As ciências sociais e o resultado de seus estudos foram incorporados pelo campo da comunicação.

Para Baccega (2002) há algumas implicações no confronto de cada ciência com as demais e a sociologia, a história e a filosofia ganham outra especificidade no diálogo interdiscursivo:

(...) no processo mesmo de incorporação, temos um primeiro momento de metassignificação, vez que essa ciência se desloca de seu domínio de origem, com as configurações que apontamos e passa a fazer parte de outro. No entanto, há outros processos, configurando outros níveis de metassignificação: ao compor o novo campo, essa ciência vai encontrar-se com outro, que também aí figuram nas mesmas condições, ou seja, na condição de metassignificação, e vai dialogar com elas, reconstruindo-se, cada uma delas nessa interdiscursividade. A interdiscursividade implica o diálogo com os outros discursos, ao mesmo tempo em que revela a especificidade do discurso construído nesse processo. (BACCEGA 2002:20).

Entende-se que muda a postura do pesquisador, diante dessa noção de indivíduo/sujeito e que novas posturas metodológicas podem enriquecer os estudos dos processos comunicacionais. Ao se considerar as mudanças, promove-se uma visão totalizadora dos problemas da sociedade, na qual a cultura e a comunicação se entrelaçam para adequar novos objetivos a um novo mundo que se constrói. A comunicação deve ser utilizada com sensibilidade e técnica, para ajudar a compreender a dinâmica da vida social e os desencontros manifestados nas interações. 
O campo de estudo da comunicação permite aos profissionais um papel de intermediação na condição de redimensionamento da própria vida social, na ampliação da visão do homem agindo e interagindo com questões sociais e não apenas no automatismo diante de decisões prontas, mas com objetivos claros a partir de um novo recorte da realidade.

Parece que por interesse dos administradores e de outros, os estudos de comunicação durante muito tempo se fundamentaram como um instrumento de transmissão de valores que predominam nos grupos sociais de cada época e seus respectivos interesses.

O conceito de comunicação depende muito da formação profissional, do modelo teórico adotado na escolha de alguns autores e as tendências que esses representam, essas definições podem ser de cunho psicológico, antropológico, filosófico e de gestão. Uma definição de interesse para esse estudo é a de Flores de Gortari e Orozco Gutierrez (1993) apontada na Tese de Felipe Chibas Ortiz (2005), segundo esses autores:

(...) comunicação é toda transmissão de informação com vista a obter uma resposta, que nem sempre implica uma acentuação passiva [...] é um processo [...] composto de três elementos: fatos objetivos, sentimentos e propósitos, dos quais com freqüência o primeiro resulta o menos relevante. (GORTARI E GUTIERREZ apud ORTIZ 2005).

Os fatos podem estar sendo vistos como o menos importante a comunicar e o mais importante talvez esteja nas diversas formas de perceber, interpretar e sentir esses fatos de acordo com propósitos ou interesses de cada público. Portanto pessoas, receptores da comunicação, com sua subjetividade, vão perceber fatos semelhantes sobre óticas diferentes, dependendo de seus interesses, conhecimentos e interação com seu meio.

Visando o receptor da mensagem, a definição de comunicação tornou-se um aglomerado de vozes, imagem, informação e está presente na vida das crianças, no supermercado, no lazer, na organização do trabalho, nos satélites.

Para efeito desse estudo o mais importante é uma reflexão sobre o papel que a comunicação assume nesse contexto de transformação social ocorrida a partir da metade do século XX e, mais especificamente, aplicada ao campo do trabalho, das relações e do comportamento humano. A comunicação desde o final do século passado tornou-se um negócio e surgiram empresas de informática, de telecomunicação, de finanças não-bancárias, de saúde, de grifes de roupas (imagem), entre tantas outras. Essa mudança de papel da comunicação no mundo da vida é qualitativa. Segundo DOWBOR (2003), isso obriga cada um a repensar o conjunto da visão que se tem de uma sociedade que se transforma. Para o 
autor, as diversas atividades "substantivas" do homem estão cada vez mais articuladas com os meios de comunicação e as fronteiras ficam borradas. Há no ar uma ampla tendência de confluência organizada de interesses e as redes de comunicação tendem a adquirir empresas dos mais variados setores. Os meios de informação e comunicação se fortalecem como instrumento central de canalização de interesses e motivações na sociedade e desempenham um papel determinante na formação dos valores ou como reflexo desses valores.

Conseqüentemente é importante compreender como a comunicação transforma o modo de viver, de fazer política, de canalizar o lazer, de controlar a vida das pessoas, de relacionar culturas, de "maquiar" as informações, de priorizar as escolhas e o consumo dos indivíduos. A internet favorece a inter-conectividade e cria novas solicitações, transforma as hierarquias nas empresas e como fenômeno, interessa às mais diversas áreas de estudos.

Entende-se que é campo de estudo da comunicação mostrar esse destino da espécie humana, o destino individual, o destino social, o destino histórico, todos entrelaçados. Uma das vocações da comunicação passa a ser o exame e o estudo da complexidade, o que conduz a busca de novos conhecimentos, e por conseqüência, desenvolvimento de novas competências e de consciência, da condição comum a todos os humanos e da diversidade dos indivíduos.

Segundo COHN (2003), a sociedade da informação demonstra que o tema informação é usado cotidianamente como acesso a conhecimento sobre objetivos e eventos. A informação tem a ver com a imposição de forma e sob a ordem da determinação se aplica além da área técnica e sobretudo ao formato da sociedade.

Torna-se importante entender que a informação não se subordina à comunicação, são campos distintos. A comunicação tem a ver com conteúdos e com sua circulação, ao passo que a informação refere-se ao modo como os conteúdos passam a circular ou não. Ainda para COHN (2003:22), “a informação não diz respeito à transmissão de conteúdos. Seu domínio é o da seleção daquilo que terá valor significativo e que, com base nesse valor, comportará o campo dos conteúdos aptos a integrarem a comunicação”. A informação refere-se ao modo de operar e, portanto, a orientação básica é no sentido de inclusão/exclusão dos informados, enquanto uma nova sociedade vai se engrenando. A comunicação refere-se a um processo aditivo, que opera por conexão.

Enfrenta-se no século XXI uma nova realidade, pois os processos de competitividade, produção e trabalho ocorrem intermediados por transformações tecnológicas, cuja intensidade 
e ritmo geram uma situação quantitativa nova, na medida em que as empresas procuram adaptar o consumidor ao que ela pode produzir, há um forte desejo empresarial de atingir o comportamento do consumidor e de criar novas necessidades de consumo. Nesse contexto, questiona-se o uso dado à comunicação e sobre a visão que vai se desenvolvendo do ser humano e da sociedade.

Portanto o que deve preocupar a todos não é apenas o surgimento dos fantásticos horizontes que as novas tecnologias trazem, mas também com o necessário avanço da reorganização do trabalho para que a tecnologia não seja uma ameaça ao trabalhador.

O grande desafio que se coloca, portanto é a construção das novas formas de organizações da produção, do trabalho, da política, da solidariedade social, formas capazes de aproveitar de maneira positiva o potencial radicalmente novo que as tecnologias apresentam. A informação generalizada pode ser um instrumento poderoso para facilitar a reconversão social que se prepara. Tal como evolui hoje, serve essencialmente para concentrar mais poder, e para aprofundar o fosso social. A democratização dos meios de comunicação constitui hoje a "linha-de-frente" das transformações. (DOWBOR 2003:58).

Na visão de Dowbor (2003) há uma proposta para que se abandone o velho argumento de que comunicação é apenas um meio ou um instrumento, é um fator determinante das transformações que a sociedade e as empresas vivem, e se tornou o eixo central das transformações estruturais.

Nas sociedades agrárias a agricultura transformou a civilização, na sociedade industrial o capitalismo pôde desenvolver-se e na era do conhecimento pode novamente transformar a civilização do século XXI a respeito da condição humana. Nas organizações uma cultura de ambiente transparente e fluido deve orientar esforços conjuntos de autotransformação da sociedade, do trabalho e das pessoas. Controlar a cultura pode parecer uma grande tentação e fonte de lucros, mas o acesso às informações, a um novo pensar, ao desenvolver-se deve ser encarado como algo essencial ao desenvolvimento do ser humano.

\section{7- Comunicação na Organização}

Novas idéias sobre administração e gestão, novas tecnologias de telecomunicações, provocam impactos na maneira das empresas se comunicarem. A comunicação tende a uma crescente descentralização e não se trata de tarefa de uma área especializada, mas de toda organização, pois os relacionamentos entre as pessoas acontecem o tempo todo, seja com público externo, público interno, fornecedores e outros. As empresas também se tornaram mais vigiadas pelo público em geral e os cuidados com a imagem das Instituições 
fortaleceram os setores de relações com os públicos externos, buscando o melhor alcance para as comunicações. Preocupa-se com a percepção desenvolvida pelos públicos com os quais a empresa se relaciona, com as pessoas que se apresentam como consumidores preservacionistas ou investidores engajados, os quais obrigam essas organizações a desenvolver uma linguagem que revele padrões de saúde, qualidade e ética.

A comunicação nas organizações é e continuará uma questão difícil porque formas diferentes e contraditórias de comunicação convivem nas empresas. Deve-se considerar como mais um agravante as relações de subordinação e formas hierárquicas que tendem a instrumentalizar a comunicação, pois muitas vezes é um instrumento de coerção sobre o trabalhador. Então fortalecer essa natureza intersubjetiva da comunicação, que emerge na empresa moderna, possibilita reconhecer a comunicação como uma competência que deve ser incluída nas práticas de gestão.

\subsection{1- Comunicação para Gerenciamento}

A comunicação no contexto do gerenciamento mantém uma relação de natureza operacional. A comunicação, a seu modo, participa e traduz as transformações da sociedade moderna. A relação que o universo da gestão estabeleceu com ela gira em torno do estudo, compreensão e condução de questões que envolvem a idéia de produção, eficácia, dominação, cooperação, solidariedade e valores.

Os conceitos de produção e eficácia contribuíram para edificar a realidade social da gestão que se conhece hoje. A comunicação contribuiu para a formação da visão de progresso econômico e social baseado na produção e eficácia. O tratamento dado ao trabalhador, na visão de homo economicus, estava embutido nos princípios da administração científica, que objetivou racionalizar o trabalho no processo de fabricação abrangendo o estudo das tarefas, seleção, treinamento de operários, divisão clara entre concepção (capacidade de planejar) e execução. Assim, o trabalhador foi estimulado a buscar melhores salários e nesse sentido, as empresas foram beneficiadas porque emergiram a visão de progresso econômico e social para ambas as partes.

A comunicação desempenhou seu papel ao responder aos imperativos da eficácia, mas seus pesquisadores também desenvolveram estudos no sentido de revelar as condições de dominação impostas ao trabalhador, presentes na organização, nos movimentos operários, no fortalecimento de sindicatos e no fortalecimento dos ideais de partidos políticos de trabalhadores. Como ciência da linguagem, buscou esclarecer sobre o sentido da produção 
para a sustentação da vida coletiva. Como forma de linguagem, a comunicação permitiu que a humanidade desenvolvesse pensamentos e um sistema de significações e relações entre eles.

Durante muito tempo o mundo da gestão precisou da comunicação numa concepção mecânica e telegráfica, com a qual os gerentes ampliavam sua visão no campo da linguagem, aprendendo a darem sentidos e significações nas trocas e na vida coletiva.

Para se aprender a viver coletivamente nas empresas, a comunicação teve sua importância no sentido de promover a busca do equilíbrio social, por meio da cooperação e da solidariedade. Em seus textos clássicos Durkheim introduziu o conceito de solidariedade orgânica, como uma perspectiva para as sociedades industrializadas lidarem com a desigualdade social imposta pelo cenário industrial, com as rupturas violentas, com as mudanças rápidas e pela necessidade de estabelecer regras e normas para que o indivíduo não caísse na anomia (indivíduo sem identidade social por ausência total de regras).

Entende-se que o Gerenciamento revelou um movimento de racionalização crescente que foi imposto à sociedade. Tourraine (1994), na obra "Crítica à Modernidade" afirmou que o poder da gestão consiste, nesta sociedade, em prever, melhorar opiniões, atitudes, compostos e modelar a personalidade da cultura. Então o ser humano é visto como um ser abstrato, objeto econômico e sem afeto, sem história e sem cultura. O ser humano faz parte de um projeto instrumental, cujas virtudes se resumem na lógica técnica, um conjunto de processos que se pode conhecer e controlar.

\subsection{2-Comunicação Autêntica para Comunicação Gerencial}

Conceituada por Zarifian (2001:165) a comunicação autêntica presente nas atividades profissionais é "um processo pelo qual se instaura uma compreensão recíproca e se forma um sentido compartilhado, resultando em um entendimento sobre as ações que os sujeitos envolvidos são levados a assumir juntos ou de maneira convergente".

Há de se aprender que para se engajar nessa comunicação cada sujeito deve possuir certo senso daquilo que ele compreende fazer, em face de um evento ou diante da elucidação de um serviço a fazer. Durante a atividade de comunicação esse sentido é colocado em jogo e transformado conforme as trocas de pontos de vista ou pela clarificação das necessidades comuns com as quais os sujeitos são confrontados e que devem levar a um acordo em termos de pensamento e ação. Sabe-se que esse sentido é algo subjetivo, mas diante de problemas ou eventos que desestabilizam as pessoas, pode ser o momento para mudar o curso do 
pensamento e das ações. O sentido tem a ver com o indivíduo e com esse "sentir" a necessidade da própria mudança e pode se tornar coletivo se a comunicação acontecer no coletivo.

É importante observar que o individual está contido no coletivo, pelo processo de socialização, mas cada indivíduo faz de suas orientações de pensamento e ações a expressão de sua dimensão individual, trata-se de sua vontade, de sua perspectiva de liberdade e civilidade. É fato que a iniciativa do indivíduo pode ser expressa na sua capacidade de comunicar e de apresentar-se engajado na dinâmica dessa comunicação. Zarifian (2001) afirma que esse significado da expressividade é essencial e de nada serve reconhecer os direitos de expressão dos indivíduos, por exemplo dos trabalhadores de base, de quem pouco se espera além do exercício de suas funções, se o seu poder de iniciativa não é levado a expressar-se em palavras, propostas de ações ou autonomia de responsabilidade por essas ações.

Se o indivíduo for visto como causa, isto é compreendido na sua subjetividade, ele será respeitado por ser a causa de seu próprio agir. Para o autor o fato de não se aceitar a comunicação autêntica produz certo mal estar na gestão. Talvez só não haverá mal estar quando a prática gerencial não estiver baseada no modelo taylorista, no sentido de passar instruções. Portanto somente haverá comunicação autêntica quando houver respeito e condições de expressão de pensamentos e ações dos indivíduos. Trata-se de um exercício.

De modo geral as posturas em termos de comunicação gerencial se apóiam numa visão de planejamento descendente dessas atividades e a comunicação favorece a orientação aos trabalhadores sobre o caminho correto a ser seguido e espera-se deles um bom comportamento conforme suas funções, sua definição de cargo e os objetivos a serem alcançados. A subjetividade é reduzida a uma preocupação da direção no sentido de que a mensagem seja compreendida e que haja um comportamento favorável.

Mesmo que a mensagem seja coerente com a função do trabalhador e com as tarefas a realizar no seu posto de trabalho, a comunicação autêntica pode existir mas não ocupar lugar relevante nessa condição. Zarifian( 2001:167) afirma:

(...) o poder de uma diretoria é limitado: ela pode controlar as maneiras de pensar e agir dos trabalhadores diante das situações concretas e dos riscos que eles devem assumir. E o fato de não aceitar essa comunicação produz freqüentemente certo mal estar na gestão. Essa pode perceber, de modo confuso, por um lado ela não compreende ou não reconhece realmente as motivações dos trabalhadores e, por outro lado, que os fenômenos essenciais para a eficiência da empresa lhe escapam. Contudo, esse mal estar não é 
suficientemente forte, a ponto de modificar o ponto de vista e a prática da comunicação gerencial, de inspiração taylorista, ou seja, que procede sempre, fundamentalmente, por instruções (qualquer que seja o revestimento ideológico dessas instruções). (ZARIFIAN 2002:167)

Se a comunicação gerencial é bastante instrumental visando ações dos trabalhadores na direção que a empresa fixa, ela deixa espaços apenas para que o trabalhador administre essas instruções gerais que são comunicadas. Esses espaços continuam sendo reguladores de comportamento. Entende-se que é preciso deixar espaço para novas aprendizagens para que as pessoas possam se apropriar, a sua maneira, das instruções comunicadas. Torna-se urgente a criação de um espaço para se aprender sobre o porquê de seu trabalho, o porquê das regras, o porquê de sua responsabilidade, o porquê de seu engajamento profissional, o porquê do imprevisto, o porquê da necessidade da empresa escolher o caminho para conduzir seu negócio e talvez o porquê da necessidade do indivíduo escolher o caminho para conduzir sua vida. Com essa postura um gerente ou um gestor reconhece a necessidade de uma outra forma de comunicação e pode ser um facilitador para a expressão e a participação do trabalhador.

A gerência e a gestão precisam aprender a reconhecer que há necessidade de outras formas de comunicação. Reconhece-se que a comunicação gerencial tem função própria e diz respeito ao que a direção espera dos trabalhadores, mas apoiar-se na comunicação autêntica e na realidade profissional vivida pelos diferentes níveis de trabalhadores pode torná-lo uma fonte reconhecida por sua capacidade de refletir. Quem reflete pode compreender sobre os desafios da empresa e sobre a própria condição na contribuição à eficácia produtiva. Refletir implica fazer emergir novas formas de engajar os indivíduos que compõem a organização, com a possibilidade de expressão de sua potencialidade, vontade de se conhecer e de auto desenvolver-se. Mas o gerente ou gestor deve ter aprendido primeiro, pois comunicação não é um "mal necessário" mas é o reconhecimento que um ponto de vista pode ser confrontado quando comparado com o daqueles que sofrem diretamente os efeitos das mutações do ambiente e das instabilidades conjunturais.

É importante observar que não se trata de introduzir mecanismos de "abertura" de canais de comunicação ou de caixas de sugestões para melhoria organizacionais, trata-se de discutir sobre o que acontece na realidade do mundo, da empresa, do profissionalismo, o momento daquela empresa, e nesse desafio podem ser colocadas questões que talvez ainda sejam apenas do domínio da diretoria. Nessa visão é importante observar que a comunicação autêntica é uma oportunidade para a comunicação ser valorizada, não como um sinal para que todos percebam que há um problema ou um evento perturbador, mas valorizada como fonte 
de re-elaboração dos rumos da empresa. Sabe-se que a empresa admite o valor da confrontação entre seu ponto de vista e do "outro", mas a utopia ganha força quando há uma visão de que a comunicação autêntica pode existir e dependerá de uma análise das causas que estão impedindo condições para seu desenvolvimento.

Essa utopia pode permitir o revigoramento das políticas da empresa, dos modelos de comunicação gerencial praticados e aceitos e da coragem de dar atenção à comunicação como competência de apoio às transformações. Não se trata de reduzir a comunicação a uma única forma social de comunicação, mas colocar em evidência a necessidade de uma reflexão sobre a questão da confrontação das idéias e dos pontos de vista em um contexto de desafios estratégicos e competências organizacionais e individuais necessárias à sobrevivência organizacional. Trata sim, de um momento necessário de lucidez e coragem para dirigentes compreenderem a importância de integrar esse conceito de comunicação aos novos modelos de gestão das empresas, em suas missões e práticas.

Para Corrado (1994), transmitir ao empregado uma nova visão não será fácil. Os profissionais de gestão precisarão aprender mais sobre pessoas, como seres com projetos de vida e profissional. Esse contexto conta com mais uma dificuldade, pois nos últimos anos a realidade foi marcada por uma administração empresarial com operações dinâmicas e enxutas, que rompeu com o antigo pacto que premiava fidelidade à empresa com a estabilidade ocupacional do funcionário.

As empresas que tiveram forte cultura de "evitar" dispensas têm feito o contrário, pois acreditam que, em longo prazo, esse comportamento será a evolução de um novo tipo de empregado, não mais fiel à empresa, mas fiel a sua própria carreira.

Para Corrado (1994) na função de comunicação organizacional há um grande número de responsabilidades a serem desenvolvidas e dentre elas, destacam-se:

- Estratégia de comunicações- Proporcionar à administração sênior a perspectiva interna e externa sobre como utilizar a comunicação para criar valor;

- Comunicações com os empregados- Apoio às responsabilidades da administração sênior e dos Recursos Humanos para se comunicar com os empregados.

Sobre "criar valor", entende-se nesse estudo que é tudo aquilo que permite orientar a evolução de uma empresa, como deseja ser reconhecida por sua credibilidade e perspectivas de agregação de valor à vida das pessoas, sejam daquelas que adquirem seus produtos ou serviços, sejam daquelas que trabalham para que isso aconteça. 


\subsection{3- A Comunicação na Prestação de Serviços}

Hoje, com a mudança tecnológica, os processos de trabalho são mais automatizados e informatizados, portanto mais integrados e exigindo uma intensa atividade de comunicação para diagnosticar problemas e inteligentemente, montar um plano de ação para diminuir possíveis impactos no todo. Apela-se para a iniciativa dos sujeitos interessados e comprometidos e sua capacidade de solucionar problemas e melhorar processos.

Cada profissional que se engaja nessa comunicação já possui senso de compreensão do que é necessário ser feito diante de um evento ou de um serviço a ser realizado. Diferente de produzir um bem, ao se estabelecer uma relação comercial ou de serviço exige-se de um profissional o diálogo com o cliente, que espera ter suas necessidades compreendidas e transformadas em um serviço oferecido. Da empresa espera-se uma capacidade interna de interpretar sobre o serviço desejado, conta-se com o engajamento profissional para produzi-lo, o que deverá ser construído percorrendo uma série de funções e contando com diferentes tipos de conhecimentos.

Verifica-se que a comunicação atinge o julgamento valorativo desse cliente e por mais objetividade que se tenha para satisfazer as necessidades do cliente, essas necessidades são sempre investidas da subjetividade desse cliente. Ele será sempre o juiz do resultado que ele espera. A comunicação torna-se fundamental, pois o valor do serviço não pode ser reduzido à objetivação de uma necessidade. Ela é necessária ao sucesso do compromisso assumido com o cliente e com certeza, nas empresas prestadoras de serviço, a comunicação se choca internamente com as divisões funcionais e profissionais, herdadas da revolução industrial que privilegiava a divisão do trabalho.

A questão paradoxal é que parece que a manutenção do taylorismo até os dias de hoje criou uma taylorização mesmo nas atividades que se exige comunicação como competência para o trabalho, a exemplo da prestação de serviço. Uma certa visão de eficiência na produção industrial, desconsidera que comunicação gera valor econômico para a empresa, porque talvez ainda se considere produtivo o trabalho que resulta em produtos materiais.

Para Zarifian (2001) o princípio de comunicação mínima da organização industrial remete "a uma concepção autoritária do controle social: todo discurso dos executantes, todo enunciado, toda palavra pronunciada são suspeitos. Seja porque os discursos não farão senão exprimir formas de resistências dos operários para com as diretrizes da hierarquia e portanto aparecerão como elemento de contestação ou de subversão da ordem social”. Então parece 
que tudo que for espontâneo, não sistematizado, será considerado não científico e por isso descartável, sob a ótica taylorista.

Refletir sobre as contribuições de Taylor, a comunicação zero, os operários pagos apenas para produzir (operar), ou seja, o não envolvimento da subjetividade ou interioridade, conforme Zarifian (2001), facilita a compreensão do processo de aceleração das transformações ocorridas nas duas últimas décadas e suas implicações no presente. $\mathrm{O}$ resultado disso é previsível, pois há uma forte tendência para que o discurso, envolvendo a comunicação autêntica, a expressividade do empregado e a interação social sejam desacreditadas. Não haverá lugar para ele pois não é legítimo até hoje.

Algumas transformações devem ocorrer e referem-se à necessidade de desenvolvimento de novas competências empresariais e humanas para adequação das organizações à era do conhecimento e de novos indicadores de competitividade. A necessidade de desenvolver novas competências para o trabalho e vida em sociedade tem como objetivo garantir o alcance de resultados em ambientes adversos, o compartilhamento de novos valores e a um novo planejar, organizar, liderar e controlar.

Conhecer sobre comunicação autêntica, para apoiar o campo profissional, valoriza a competência comunicacional como uma ponte com a aprendizagem e para o aumento da capacidade de pensar e agir em conjunto, para dar sentido às ações requeridas e efetuar as mudanças necessárias, para construir novos conhecimentos requeridos, para saber lidar com aquilo que já não é mais rotineiro e conhecido.

\subsection{4- Comunicação para Administração de Recursos Humanos}

Para Corrado (1994), uma estratégia organizacional que se proponha unir Comunicações e Recursos Humanos, precisa incluir um compromisso da administração para comunicações de recursos humanos fortalecidas, declaração de políticas de RH para as comunicações [...] a estratégia específica de RH para a questão da comunicação inclui os interesses dos empregados como pontos de referência, obtidos por meio de análises de atitudes. Nesse estudo observa-se a necessidade de ir além da análise das atitudes, pois há necessidade de se compreender que a empresa considera seu capital humano associado ao negócio da empresa, mas pouco se sabe da visão que as pessoas têm do seu trabalho, do que se espera delas, da necessidade de desenvolvimento de novas competências e do 
desenvolvimento humano e profissional. A Comunicação para Recursos Humanos tem se apresentado sob seu aspecto instrumental e visa resultados organizacionais.

\section{Análise do Ambiente Interno}

A comunicação PARA Recursos Humanos percorre inicialmente o ambiente interno da organização e assume um caráter quase que educativo, na medida em que a comunicação envolve aspectos de transparência quanto ao desempenho esperado dos funcionários. Essa comunicação pode ter base na declaração da Missão da organização, da Visão, das Crenças e Valores que devem criar condições de perspectiva de ação para cada indivíduo.

A comunicação é um instrumento para ampliar a visão do profissional no sentido do seu alinhamento com os objetivos organizacionais e da busca de desenvolvimento pessoal e profissional, de acordo com seu objetivo individual. Nesse sentido a comunicação formalizada em documentos, ações práticas e "fala" dos gestores estimulam uma idéia de cultura organizacional que sinaliza as capacidades da organização de pensar, sentir e agir por meio das pessoas.

A idéia de cultura transpassa da condição de preservação para transformação. $\mathrm{Na}$ perspectiva antropológica, uma nova dimensão comunicada deve ser capaz de integrar inúmeros aspectos da prática social. A comunicação pode possibilitar ao indivíduo perceber que existe uma correspondência entre os significados por ele atribuídos ao objeto e os significados atribuídos pelos outros, isto é, existe o compartilhamento da visão sobre a realidade. A organização é mantida através de modos simbólicos, como a linguagem que facilita os significados compartilhados e a realidade partilhada.

Para Fleury (1989), a cultura organizacional é concebida como um conjunto de valores e pressupostos básicos expressos em elementos simbólicos, que em sua capacidade de ordenar, atribui significações, constrói a identidade organizacional, pois tanto agem como elemento de comunicação e consenso, como ocultam e instrumentalizam as relações de dominação.

Eis, portanto, mais um desafio para Recursos Humanos: gerenciar a cultura das organizações incorporando a dimensão das relações de poder e da percepção que as pessoas têm da organização em que trabalham. Na visão de Kreps (1990), a comunicação pode ajudar os membros da organização a trabalhar através das distintas interpretações da realidade e aprender uns com os outros. A comunicação como uma preocupação mais contemporânea, pode ser um elo para traduzir nas políticas de pessoal e na organização do trabalho, o respeito 
pela importância da percepção e da opinião das diferentes pessoas, que compõem uma empresa.

O segundo desafio está na comunicação dos profissionais da área de Recursos Humanos com as demais áreas, que deve suprir a necessidade de orientar sobre questões internas, políticas, acordos trabalhistas, práticas anteriores e atuais, necessidade dos funcionários, condições e tendências externas de mercado de trabalho, dados econômicos, emergências globais, aspectos sociais e legais. O cuidado com a comunicação pode ser de valia para tomada de decisão, clareza dos obstáculos para alcance de metas e resultados e outras responsabilidades concernentes a rotinas como recrutamento e seleção, planejamento e condução de programas de treinamento, carreira, benefícios, remuneração e comunicação com os funcionários, dentre outros.

\section{8- Atração de Recursos Humanos com Potencial para Desenvolvimento}

No sentido de uma participação estratégica de Administração de Recursos Humanos, as atividades de recrutamento e seleção são consideradas partes de um processo de gestão de pessoas e visam atrair para a organização pessoas com talentos diversos e com potencial para ocupar novas funções futuras, de acordo com os objetivos estratégicos da organização.

A comunicação na seleção objetiva garantir a competitividade da empresa com as novas contratações e modifica os critérios e posturas requeridas dos participantes no processo, inclusive daqueles que serão os gestores diretos ou parceiros dos candidatos aprovados. Portanto, o envolvimento de outros profissionais além daqueles de Recursos Humanos revela a necessidade de um comprometimento com o desenvolvimento do profissional escolhido. Trata-se de uma preocupação com o nível macro da organização e adoção de um novo paradigma: atrair as pessoas certas para a empresa e, de acordo com a estratégia de negócio. $\mathrm{O}$ candidato ideal para a organização é aquele que revela no seu CHA, uma possível complementaridade para o perfil da equipe atual, visando o presente e o futuro da organização.

Para Marras (2000:262) um novo paradigma altera os procedimentos da Administração de Recursos Humanos, que deve preparar os demais envolvidos para a nova missão. Assim: 
A partir desse novo paradigma, certas características deverão ser prospectadas com maior rigor nos processos seletivos estratégicos de $\mathrm{RH}$, como por exemplo:

- Maior preocupação, nas entrevistas com questões ligadas às raízes dos indivíduos; seus laços de comprometimento e alcance de resultados nos núcleos sociais em que convive (igreja, clube, família, empresa, etc.).

- Análise profunda dos níveis de quociente-inteligência (Q.I.) e quociente-emocional (Q.E.) avaliando situacionalmente os diversos graus de raciocínio e relacionamento com o mundo exterior.

- Os aspectos natos e o estilo de liderança praticado pelo candidato.

- Traços específicos, como nível de agressividade voltado para processos produtivos, controle e resistência às pressões, flexibilidade técnica e política, coragem decisória e nível de intuição, são fortes determinantes de bons candidatos no modelo estratégico de $\mathrm{RH}$.

- $\quad$ Nível motivacional (energia interior) elevado, preferencialmente já situado no campo da auto-realização ou em busca dela.

- $\quad$ Forte presença de ambição, como alavanca propulsora da persistência necessária para atingir objetivos pessoais e organizacionais de difícil realização. (MARRAS 2000:262).

\subsection{1- Avaliação de Performance e Retenção de Talentos}

A expectativa de performance ou desempenho de um profissional numa organização deve ser compreendida numa dimensão que envolva o grau de desenvolvimento individual e sua contribuição com o negócio. Tradicionalmente esse desenvolvimento era observado pela análise clássica do cargo e por experiências acumuladas ao longo da vida profissional. A nãoobservância da multiplicidade de aspectos dentre os quais um profissional pode ser avaliado tem se apresentado como um fator crítico para compreensão do desempenho nesse novo padrão de aferição de potencial, de análise comportamental, do desenvolvimento profissional, da realização de metas e alcance de resultados. Novas diretrizes de Recursos Humanos devem contribuir para uma aferição do potencial e da capacidade das pessoas de responder ou não, aos diferentes graus de complexidade exigidos nas suas atividades. Reter talentos exige comunicar sobre a condição atual e a desejada do profissional. Nesse sentido, Santos (1999) reforça que:

A importância da comunicação do propósito estratégico, da negociação, das metas estratégicas e dos valores organizacionais, da transparência administrativa, da reformulação de modelos mentais, da confiança mútua, da fusão do trabalho operacional e gerencial, do gerenciamento de desempenho, entre outros, para viabilizar a realização profissional dos indivíduos. (Santos 1999: 55). 
A comunicação pode facilitar a compreensão dos funcionários gestores e dirigentes, quanto à afetiva participação do profissional e perspectivas de reconhecimento e de ocupação de novos espaços organizacionais. Logo a avaliação de performance favorece a comunicação autêntica e facilita em processos de negociação e busca de equilíbrio entre as expectativas organizacionais e as individuais. Trata-se de uma visão mais refinada sobre a empresa e seu quadro de profissionais, incluindo os funcionários de linha, gestores e dirigentes, pois revela as fragilidades e pontos fortes e facilita no suporte ao desenvolvimento.

Essa visão pode trazer um resgate do significado do trabalho, como algo que vai além do conceito de subsistência ou sobrevivência, pressupõe a crença do desenvolvimento para se alcançar equilíbrio e sabedoria na compreensão da realidade e da vontade de agir sobre essa realidade.

\subsection{2- Desenvolvimento do Capital Intelectual}

A comunicação torna-se fundamental para esclarecer sobre novos paradigmas da Administração de Recursos Humanos quando se refere ao desenvolvimento do capital humano nas organizações. Esses aspectos na visão de Ulrich (2001) referem-se a três pontos relevantes: o primeiro diz respeito a alavancagem do capital intelectual que pode ser desenvolvido com a aprendizagem. Para Ulrich (2001), capital intelectual é a soma do conhecimento de todos os participantes de uma organização; então um profissional comanda um corpo de conhecimentos, mas esses conhecimentos podem se modificar de acordo com as necessidades, com apoio da aprendizagem contínua. Para efeitos de estudo o autor identificou o intelecto profissional de uma organização em quatro níveis de análise: o conhecimento cognitivo desenvolvido por treinamento e certificação, as habilidades avançadas que se referem à capacidade de lidar com problemas complexos a compreensão sistêmica envolvendo uma teia de relacionamentos de causa e efeito e a criatividade automotivada que consiste na vontade, na motivação e na adaptabilidade.

Há necessidade do apoio da comunicação para elevar a visão de desenvolvimento associado à capacidade criativa. Ulrich (2001) considera que o valor do intelecto aumenta quando se sobe da escala intelectual do conhecimento cognitivo para a criatividade automotiva.

Ainda hoje nas empresas o que mais se observa é uma atenção com treinamento direcionado para desenvolvimento de habilidades e pouca ou nenhuma atenção à capacidade 
criativa. Sabe-se que o estímulo à aprendizagem permite o acesso a novos conhecimentos e informações que poderão contribuir com a criatividade se as pessoas aprenderem sobre compartilhamento e troca.

Os outros dois aspectos considerados pelo autor dizem respeito ao capital social que tem como base às redes de relacionamento que são estimuladas na organização e que permitem uma troca de conhecimentos, de visão e que privilegiam o surgimento de novas idéias e o capital emocional que se refere à capacidade do homem de pensar, sentir e agir em equilíbrio. A comunicação autêntica tem papel de suma importância para o desenvolvimento do capital emocional quando promove e estimula a compreensão de si próprio e a perspectiva de aprender sobre auto-análise, a partir de feedback recebido das demais pessoas.

$\mathrm{Na}$ visão de Terra (2000) para a empresa sobreviver no ambiente competitivo atual, terá de desenvolver capacidades e habilidades para participar das indústrias de poder “cerebral”. Treinamento na visão clássica não serve mais como o único caminho para desenvolvimento do intelecto. Há uma limitação gritante nas atividades de treinamento objetivando busca de conhecimentos para soluções técnicas, para resolução de problemas de conflito e de fortalecimento das comunicações e da cultura organizacional.

Nesse sentido o treinamento funciona como um estímulo aos funcionários para apoiar a realização de um trabalho bem feito e longevidade na organização. Observa-se que nem sempre as pessoas que participam dos treinamentos passam a rever posturas e utilizar os novos conhecimentos adquiridos. È um paradoxo atual, pois os treinamentos sempre objetivaram a manutenção da ordem vigente e o reconhecimento da organização como instituição eficiente, eficaz e efetiva. Para o treinando a atividade representava a possibilidade de ascensão hierárquica, manutenção de emprego, oportunidade de qualificação e de relacionamento com os outros profissionais.

Baldissera (2000) afirma que os treinamentos permitem às organizações comunicar uma determinada ordem, reiterando valores e códigos e por outro lado, não significa que os treinados os assumam passivamente. Considera-se que o treinando, caso não concorde ou aceite o que é apresentado, possivelmente procederá com um "mascaramento" de suas opiniões para adequá-las aos estereótipos de sentido mítico e ritualístico. É importante atentar para o fato de que a ação do treinamento, envolvendo as figuras do treinando e do instrutor sempre agregará ao processo de comunicação as marcas das experiências, crenças e valores de cada um, pois a mudez não é bem aceita. 
Esse fato nos leva a questionar que o treinamento não pode representar apenas o caminho para informar e formar seus funcionários, é preciso comunicar explicitamente o processo de transformação que o conhecimento trouxe para a vida das pessoas e das empresas. Não basta querer "lapidar" ou promover mudanças de atitudes se o treinamento não procurar comunicar sobre a necessidade de uma visão ajustada às mudanças.

Para a efetiva desconstrução das estratégias usadas pelos treinamentos, pensa-se na comunicação autêntica favorecendo um quadro de menos manobras e mais compreensão sobre objetivos organizacionais e individuais alinhados ao contexto de novas competências para o século XXI.

Primeiramente, é preciso que se atente para o fato de que as organizações, conhecedoras do valor das informações (boas, procedentes) e do poder que se constrói a partir de seu domínio, mudam-se de tecnologias e profissionais qualificados para desenvolver conjuntos de procedimentos que lhes permitam concentrar as informações para, estrategicamente, utilizá-las. Porém parece que o modo como elas compreendem a comunicação, é de certa maneira, estéril. O que se quer dizer é que, no âmbito da organização, a comunicação tende a ser entendida como sistema para que as informações possam circular, verticalmente, entre ela e seus públicos. Essa compreensão percebe os públicos com elevado grau de passividade, o que tem como conseqüência imediata, o uso de estratégias de comunicação que não consideram o processo de construção e disputa dos sentidos que se dá nas materializações comunicacionais. (BALDISSERA 2000: 31).

A comunicação autêntica pode contribuir para a Administração de Recursos Humanos inovar com elementos que permitam a revisão de comportamentos individuais e de práticas na organização. "A comunicação oficial poderá ser construída sobre verdades sociais uma vez que a sociedade espera que as organizações, de alguma maneira, criem oportunidades para que os funcionários possam ampliar seus conhecimentos, qualificando-se." (BALDISSERA, 2000:35).

\section{9- Aprendizagem Organizacional}

Quando se pensa na organização como um sistema que pode construir e facilitar comunidades de aprendizagem e de prática entende-se que há uma necessidade de se concentrar em questões de desenvolvimento pessoal, para as quais o conhecimento só pode ser criado pelos próprios indivíduos, ressaltam Nonaka e Takeuchi (1997).

As organizações aprendem, conforme ensinamentos de Senge (2004), à medida que suas pessoas desenvolvem cinco disciplinas básicas: pensamento sistêmico (acreditar que tudo acontece em sistemas interconectados), domínio pessoal (viver, cada um, a serviço das suas 
mais altas aspirações), modelos mentais (desvendar pressupostos arraigados que influenciam a maneira individual de ver o mundo), visão compartilhada (traçar metas genuinamente comuns para que todos aprendam porque querem), aprendizagem em equipe (pensar em conjunto). Todas as cinco disciplinas têm a ver com grupos de diálogo. As duas últimas especialmente existem na presença do diálogo, como sua "pedra-de-toque".

Para Santos (1999), no contexto de aprendizagem organizacional, atividades que envolvam desenvolvimento profissional exigem o envolvimento do funcionário desde a colaboração na elaboração de um conteúdo de treinamento até a reflexão sobre o treinamento no ambiente de trabalho. E ainda, observa que essa é a oportunidade que os líderes das equipes têm de se envolver mais com o treinamento daqueles que lideram ao invés de deixar essa responsabilidade para os profissionais de Recursos Humanos. Entende-se nessa visão que eles se tornam diretamente responsáveis pela gestão das equipes e pela contribuição dos membros da equipe no sentido de agregar valor, revelando as capacidades de pensar, sentir e agir.

Logo, pode se considerar, sob um aspecto, que a aprendizagem individual promove a aprendizagem organizacional. Conforme Argyris (1999) cabe à organização criar um ambiente, que permita aos indivíduos aprenderem, pois o processo de aprendizagem organizacional implica definição de novos comportamentos que facilitem a compreensão do que ocorre no ambiente interno e externo à organização. Para o autor deve-se considerar que as organizações que promovem o aprendizado também estão renovando e ampliando os estoques de conhecimento organizacional. Verifica-se que aprendizagem organizacional implica renovação da própria organização e de sua capacidade de lidar com sua complexidade.

Nesse sentido de auto-organização pelo desenvolvimento da capacidade de estar aprendendo continuamente, as empresas e o RH podem ser favorecidas se houver uma preocupação com uma comunicação que possa fluir, entre pessoas, entre áreas, entre níveis diversos, visando à criação de competências interdisciplinares. A preocupação com a aprendizagem ressalta a importância e a clareza no fato de que todos os membros participam e contribuem para a criação de novas idéias sobre a realidade e sobre o conhecimento.

Pode ser utilizado como referência o trabalho de Peter Senge, autor de "A Quinta Disciplina", que é um dos fundadores da "SOL" (Society for Organizational Learning), cujo propósito é favorecer uma mudança de consciência e uma solução em direção ao desenvolvimento integral de pessoas e comunidades sustentáveis no planeta. 
A "SOL" é uma das grandes instituições para disseminação e resgate do processo de diálogo.

\subsection{1- Compreensão para Aprender}

Grande parte do tempo, pessoas com acesso a muitas informações podem estar experimentando apenas uma armadilha intelectual com empréstimo de conhecimentos, aos quais não sabe dar um significado maior. Lidar com os conceitos de compreensão e aprendizagem gera um novo estado de ser, capaz de experimentar a interconexão da vida e perceber o todo ao invés de partes, significa ter consciência do presente, do que está acontecendo no exterior e como isso afeta o interior de cada ser.

Ao se perceber como as coisas se inter-relacionam, cada um pode desenvolver a consciência de que faz parte do mundo e não está separado dele. As novas competências referem-se a aprender para ter clareza das ações - a sua própria e a do outro e ainda, as conseqüências delas para o todo. A compreensão do conceito de competência leva ao desenvolvimento de ações novas porque mudam as regras e os valores básicos.

\section{2- Gestão COM Pessoas - Gestão, COMUNICAÇÃo e Pessoas}

A cultura do gerenciamento e do homem administrativo fez surgir palavras como gestão, gerir e gestor. As ações do gestor são fundamentadas nos princípios administrativos: eficácia, produtividade, performance, competência, empreendedorismo, qualidade total, cliente, produto, marketing, excelência. Esses mesmos princípios são aqueles que orientam a Administração de Recursos Humanos e toda a empresa. Por isso mesmo na vida privada a racionalidade e o gerenciamento estão presentes e mesmo se tratando das emoções, as pessoas aprendem sobre gerenciá-las, assim como se aprende como gerenciar o tempo, a imagem e a identidade. Os princípios de gerenciamento estão presentes na vida organizacional como forma de explicar e interpretar o mundo a partir das categorias da gestão. Uma sociedade de gestores busca racionalizar todas as esferas da vida social.

\section{Metáfora da Moeda}

Considerando a natureza e as exigências do gerenciamento quanto às práticas e processos, entende-se que são as pessoas que detém os postos na hierarquia das empresas, que 
são elas que exercem as funções de gestores e são elas que devem mudar seu nível de atuação em consonância com as novas exigências.

Os profissionais em Administração de Recursos Humanos e gestores fazem parte das estruturas organizacionais e, portanto, foram fortemente influenciados pela racionalização do mundo da administração científica, mas por outro lado, também se encontram fortemente pressionados a criar novas práticas com relação à gestão das pessoas.

Reconhece-se que a grande marca da Gestão versus Administração está na orientação para idéias de desenvolvimento mútuo: pessoas e organização. Trata-se de uma moeda com um único lado - a pessoa como profissional transforma-se em gestora de sua relação com a empresa, bem como de seu desenvolvimento profissional e garante uma avaliação satisfatória, revelando o nível de comprometimento profissional e a "entrega" de seus conhecimentos transformados em capacidade de mobilizar sua inteligência, seu potencial criador, sua capacidade de interpretar o contexto e de agir com responsabilidade, de modo que ela gere vantagens competitivas únicas para as empresas. O discurso das organizações é de que as pessoas são o principal capital de uma empresa.

O outro discurso coloca a área de RH no papel estratégico, que deve atuar de forma estratégica com foco nas pessoas e nas necessidades de negócio. Novas competências são requeridas dos profissionais que atuam na área de RH e essas se estendem aos demais gestores de pessoas: conhecimento do negócio da empresa; busca de profissionais com potencial para desenvolvimento das novas competências requeridas; retenção de talentos; desenvolvimento de equipes; remuneração por resultados; estímulo à aprendizagem contínua e relacionamento com público interno e externo.

No único lado da mesma moeda, novos contornos para políticas de administração e gestão de pessoas voltam-se para obtenção de resultados em termos de inovações, qualidade de produtos ou serviços e produtividade no trabalho.

A herança gerencial das escolas de administração afeta as perspectivas de transformação da Administração de Recursos Humanos para efetivação dos modelos de gestão de pessoas, pois a área responsável por procedimentos descritivos e pelo modo de funcionamento da organização é também a responsável pelas práticas ideológicas do sistema econômico. Pagés (1987) observa que "não podemos dissociar os procedimentos, os dispositivos e o discurso destes dispositivos, da maneira como funciona, como são vividos pelos indivíduos". Talvez aqui possa ser criado um espaço para análise de causas e possa ser 
introduzida a questão dos resultados humanos, pois as pessoas vivem esse drama. Observa-se que o processo de valorização dos indivíduos pelo mercado e pela empresa está vinculado ao nível de agregação de valor que a pessoa traz para a empresa e para o negócio. Não se pode perder de vista que ao se analisar o sentido do trabalho na sociedade contemporânea sob o foco do sistema econômico, o peso do dinheiro como meio de controle acabou por "abafar" o sistema de interação social e a esfera da comunicação.

Toda teoria de administração relega esse fato e a comunicação ocupa poucas páginas de algumas obras teóricas em Administração de Recursos Humanos. As escolas continuam formando profissionais para que eles próprios acreditem que serão pessoas melhores se gerarem melhores resultados para a organização. No entanto se Comunicação for ensinada com ênfase na sua instrumentalidade, o mesmo ocorrerá com as disciplinas com aderência em RH.

Dois dos autores clássicos em Administração e Comportamento Organizacional, Davis e Newstrom (2002) referem-se ao enfoque de RH baseado no desenvolvimento das pessoas, no sentido de preparar pessoas para que elas atinjam níveis cada vez mais altos de competência, criatividade e realização. Eles reforçam esse papel instrumental de RH como a área que dá suporte ao desenvolvimento profissional:

A posição de recursos humanos, por outro lado, é de apoio. Ela ajuda os empregados a se tornarem melhores, mais responsáveis e então tenta criar um clima no qual eles podem contribuir até os limites do desenvolvimento de suas habilidades. Assume que expandindo as capacidades e oportunidades para as pessoas chegar-se-á diretamente a melhoria da eficiência operacional. A satisfação no trabalho também será um resultado direto quando os empregados fazem uso mais complexo de suas habilidades. Essencialmente o foco dos recursos humanos significa melhores pessoas que atingem a melhores resultados. (DAVIS e NEWSTROM 2002:14).

Portanto as transformações na gestão devem ser entendidas como uma urgência para romper com essa falta de interação dos atores da organização, logo, não se trata de adaptação ao novo contexto ou mudança de discurso.

O que parece é que foi delegada à Administração de Recursos Humanos a responsabilidade para buscar soluções para problemas que possam impedir as organizações de manterem-se vivas. Não se questionam as causas que possam estar impedindo essas transformações, nem os efeitos sobre as pessoas. Promove-se a incorporação de novos modelos de gerenciamento, derivados das grandes companhias japonesas e freqüentemente, condiciona-se a vida no emprego aos fatores alto-compromisso e alto-desempenho para maior produtividade dos sistemas de trabalho. 
Nesse sentido, Boog (1995) contribuiu quando afirmou que o sucesso de uma organização é medido em três dimensões complementares: resultados financeiros, mercadológicos e operacionais; pessoas, incluindo o clima interno da organização, o ambiente de trabalho, a relação com a comunidade, os hábitos, as escalas de valores e a filosofia da empresa e a inovação e flexibilidade, isto é, grau de abertura, sensibilidade, possibilidades e interesse da organização em promover mudanças e renovações em sua forma de agir, em antecipação ou resposta às demandas mutáveis do meio ambiente.

Porém esse tipo ideal de trabalho está, paradoxalmente, colidindo com a realidade da insegurança no emprego. A mobilidade no emprego é agora um fato da vida. Teme-se que ao desenhar novos formatos de estruturas organizacionais baseados nas competências, uma nova condição no trabalho esteja apenas mascarando o tumulto humano envolvido.

A flexibilidade pode atingir as pessoas porque requer novas aprendizagens e adaptações, mas é a estabilidade que pode atingi-las ainda mais através de economias deprimentes. É bom lembrar que em países industrializados na década de 1970, a segurança no emprego era associada com uma produtividade mais alta e não se falava em inovações de produtos e assim, nos anos 1980, esta conexão desapareceu. O modelo de emprego tipo vitalício ou de carreira única, que foi estimulado em muitas empresas, preocupou-as muito, em décadas passadas, quando uma rotatividade muito baixa criou uma "leva" de empregados sem valor competitivo e que impedia a admissão de novos talentos. Nesse sentido um bloqueio às novas idéias fora construído em nome da segurança no emprego que habilitava empregados com muito tempo de casa a se recusarem a fazer certas coisas, sabendo que eles podiam sempre se transferir para outro departamento. Em contrapartida muitas empresas recém criadas, de rápido crescimento, baseiam suas políticas de recursos humanos em oferecer boas oportunidades de trabalho, mas sem garantia de estabilidade.

Outros paradoxos se apresentam, pois a mobilidade é tanto uma causa quanto um efeito de uma combinação inadequada entre as pessoas e os trabalhos. Em muitas partes do mundo, faltas ao trabalho e excessos de trabalho coexistem. A mão-de-obra tem um perfil de habilidades, mas o trabalho tem outro. A educação e habilidades estão aumentando em países em desenvolvimento, mas o trabalho está em países industrializados.

Uma melhor combinação entre habilidades da mão-de-obra e as necessidades empresariais devem significar que as pessoas possam crescer em trabalhos de maior habilidade sem traumas. Novas políticas devem refletir novas formas de segurança enquanto abarcarem novas realidades de flexibilidade, mobilidade e mudança. 
Uma nova utopia nasce com o vocabulário das competências e habilidades, essa pesquisa procurou resgatar elementos da ciência administração e seu legado de gerenciamento, os quais foram se somando ao longo de quase um século, até que hoje se possa aceitar como verdadeiros alguns termos como "aprendizagem constante", "aquisição de competências e conhecimento", "competitividade", "enfrentamento do mercado de trabalho", entre tantos outros.

Administradores de Recursos Humanos têm contribuído para que novos sentidos ao trabalho humano sejam legitimamente considerados como parte das regras ou normas de comportamentos esperados nas organizações. Com o propósito de cumprir seu papel na organização e alinhada às novas verdades, a Administração de Recursos Humanos contribuiu para a institucionalização de certa forma de vida, que tem implicações imediatas sobre como as pessoas se comportam, sobre como convivem umas com as outras, como se admite o "outro", sobre como se acha que deve ser a vida e as relações mútuas.

Trata-se de não alimentar o "quadro de esquizofrenia", conforme temática abordada por Wood Jr, porque é visível a todos que, graças à contínua reestruturação das relações sociais que se assiste hoje, há um enfraquecimento da ação do Estado no âmbito das relações entre empregador-empregado, há um esgotamento de modelos de condutas pessoais, as quais agora têm à disposição uma grande variedade de linguagens com as quais podem lidar, há uma espécie de privatização moral das responsabilidades pela ação, quer seja no caso do trabalho, enquanto projeto individual ou de performance, quer seja no caso das questões tratadas como públicas - ações coletivas, a política, órgãos e sistemas de representação etc. Nesse contexto, há uma forte e vigorosa injunção no sentido de forçar o indivíduo a agir por conta própria.

Olhando a moeda de um lado só, verifica-se que há nas empresas um incentivo muito grande para que seus funcionários sejam empreendedores, atualizados, enfim, há uma pressão para que adquiram permanente capacitação. O que parece é que o indivíduo está arcando com deveres que caberiam à empresa, por exemplo: custos de formação, embora alguns possam argumentar que muitas empresas investem muito nesse sentido, inclusive com Educação Corporativa ou, quanto o Estado tem investido em políticas de re-qualificação, de treinamento ou de re-inserção profissional. Sabe-se também que atualmente, se um profissional não age por conta própria ele pode ser classificado como "acomodado", "sem iniciativa", "fracassado", entre tantas outras designações moralmente depreciativas. Essa talvez seja uma das razões 
pelas quais as escolas de administração de empresas e as obras literárias proliferam e atraem milhares de alunos ansiosos por uma garantia de diferencial no mercado de trabalho.

\section{1- A Gestão}

Os profissionais nas organizações aprenderam princípios gerenciais, cuja base está em não forçar o processo de crescimento das pessoas, mas enfraquecer a sua fonte de limitação, treinando, capacitando e desenvolvendo um padrão de comportamento organizacional. Esta visão de gerenciamento trouxe transformações sociais e organizacionais, que são caracterizadas por: busca da hegemonia do econômico, culto à empresa e influência crescente do pensamento empresarial sobre as pessoas. Essa visão gerencial também influenciou na dinâmica e no tipo de sociedade que se conhece hoje.

Foi a partir da Revolução Industrial que a razão e o progresso deram voz a uma sociedade em movimento acelerado, orientada pelo crescimento econômico e pelas aspirações democráticas; uma lógica que sustenta o modelo capitalista, da propriedade privada e do jogo de interesses pessoais, da busca de lucro e da acumulação que se impôs gradualmente, em todas as partes.

\subsection{1- Contexto de ameaça estrutural ao trabalho}

Provavelmente as empresas não se orgulhem de oferecer benefícios reduzidos e baixos salários, mas essa foi a principal alternativa para a recuperação das grandes empresas no mercado global.

Os últimos 20 anos, sob influência da lógica técnica e da racionalização acelerada dos modos de gestão, que visam reduzir o tempo de resposta da produção e o custo operacional, foram marcados por desaceleração do crescimento, redução da produtividade, deterioração dos salários, queda dos benefícios sociais, aumento do desemprego, expansão do trabalho precário e do aumento da miséria.

Complementando essa visão, Thurow (1997) faz uma menção de que as pessoas têm sido abatidas por critérios de seleção, pelos quais a idade, o trabalho temporário e o teletrabalho, entre outros, ampliam o desemprego e o subemprego.

A Administração de Recursos Humanos pode estar diante de estragos de concepção antropológica que reduzam a condição humana, o que pode gerar na sociedade e nos 
indivíduos conseqüências humanas irreparáveis diante dos processos constantes de reestruturação: conclama-se a flexibilidade e a aprendizagem contínua das pessoas para que elas se apóiem numa única certeza: a de que somente a incerteza existe.

Esta é a comunicação corrente e as pessoas podem perder o sentimento de segurança e de perspectiva de criar novas alternativas para tomada de decisão porque perderam a liberdade para experimentar novas idéias. Esse agir "acuado" também afeta as questões da convivencialidade, pois representa o enfraquecimento da coesão social e nesse cenário, a tendência é que as pessoas se tornem mais prudentes e com maior dificuldade em estabelecer relações informais, evitando os acordos espontâneos mesmo entre colegas.

Não há como negar, mas hoje a empresa confunde-se com a gestão do aspecto financeiro. É sabido que com o aumento do nível de estresse profissional, a tendência é que a confiança degrade-se, o cinismo desenvolva-se e a angústia econômica estrangule cada vez mais as pessoas. "A economia marcha contra a sociedade enquanto a lógica financeira predomina sobre a lógica econômica", afirma Thurow (1997).

O gerenciamento de pessoas está inserido nesse contexto e a urgência em ampliar novos horizontes torna-se inadiável. Essa ampliação de horizontes passa pela reafirmação de algumas conotações sobre o que consiste a especificidade da espécie humana e principalmente, por uma contribuição mais ampla da ciência da comunicação: considerar a realidade humana e o homem como ser vivo, consciente e sociável.

Para Chanlat (1996):

Torna-se importante passar à apresentação de alguns elementos para uma teoria antropológica das organizações [...] "apreender a realidade humana nas organizações e apresentar os primeiros elementos de uma teoria antropológica em construção, distinguindo cinco níveis estreitamente correlacionados: do indivíduo, da interação, da organização, da sociedade e do mundo". (CHANLAT 1996:34).

Entende-se que essas dimensões esquecidas do indivíduo na organização e o foco da empresa centrada no mundo da gestão financeira criaram uma geração de pessoas amputadas dessas dimensões fundamentais e, como conseqüência, o agente social tornou-se um calculador racional. Na comunicação, o emissor e o receptor de mensagens, podem ter aprendido a desconsiderar o lado humano como primeiro plano nessa relação.

Segundo Enriquez (1997) a gestão privilegia a ação, a frieza, o conformismo, a masculinidade, a racionalidade industrial, a certeza, o universalismo abstrato e a tecnocracia. A realidade do gestor eficaz é cheia de paixões, manobras, panelas, desejos inconfessáveis, 
resultados incertos, comportamentos desviantes, sociabilidade paralela, inveja, ciúmes e diferenças.

Ao mundo do gerenciamento opõe-se o mundo a ser vivido porque o universo oficial da gestão deixa pouco espaço aos aspectos da condição humana. O autor esclarece que "para além da vontade de organizar alguma coisa estável, esta situação explica-se pelo medo do disforme, das pulsões, do desconhecido, dos outros, da palavra livre e do pensamento".

\subsection{2- A Subjetividade na Gestão}

Existe um agravante nessa questão da não-iniciativa do sujeito. Diante de tantos apelos sobre assumir responsabilidades com base em seus conhecimentos, empreender na própria vida e carreira mostrou-se como um estímulo ao desenvolvimento da competência individual, que será sempre colocada à prova (e cada vez mais), porque cada um estará sendo capacitado para desenvolver um código de sobrevivência que valoriza em demasia a ação individual.

Pouca importância tem sido dada às questões de convivencialidade ou de coletividade, visando os propósitos de sustentabilidade da condição humana.

A proposta da "CHAVE" de Macarenco e Zamora (2006) procura acrescentar uma transformação semântica no vocabulário do indivíduo, que se deixou levar por normas e condutas fixadas pela empresa e pela sociedade, mesmo que sem o seu consentimento.

É necessário ampliar a percepção do cenário no qual cada um está inserido. Conciliar os processos emocionais e racionais leva à compreensão de que é preciso saber equilibrar e harmonizar as Competências Técnicas e Comportamentais, presentes no "CHA", com as Competências Abstratas da Vontade e Expressão, presentes na "CHAVE".

As competências individuais referem-se ao fortalecimento da interioridade do ser para que ele aprenda a se ver como parte do todo, porque também ele é um ser completo e capaz de agir como Ser Total, em condições de pensar, sentir e agir.

A Tabela 1- "CHAVE" representa as competências técnicas (Pensar e Sentir), competências comportamentais (Agir) e competências abstratas (Ser Total). 
Tabela 1 - CHAVE

\begin{tabular}{|c|c|c|c|c|}
\hline $\mathrm{C}$ & $\mathrm{H}$ & A & $\mathrm{V}$ & $\mathrm{E}$ \\
\hline \multicolumn{2}{|c|}{ Competências Técnicas } & $\begin{array}{l}\text { Competências } \\
\text { Comportamentais }\end{array}$ & \multicolumn{2}{|c|}{ Competências Abstratas } \\
\hline $\begin{array}{l}\text { Conheci } \\
\text { mentos } \\
\text { (Pensar) }\end{array}$ & $\begin{array}{l}\text { Habilidades } \\
\text { (Sentir) }\end{array}$ & $\begin{array}{l}\text { Atitudes } \\
\text { (Agir) }\end{array}$ & $\begin{array}{l}\text { Vontade } \\
\text { (Querer) }\end{array}$ & $\begin{array}{c}\text { Expressão } \\
\text { (Compartilhar) }\end{array}$ \\
\hline $\begin{array}{l}\text { Conhecimen } \\
\text { tos técnicos, } \\
\text { cursos, } \\
\text { especializaç } \\
\text { ões, } \\
\text { capacitações }\end{array}$ & $\begin{array}{l}\text { Saber o que fazer } \\
\text { com os } \\
\text { conhecimentos } \\
\text { Habilidades } \\
\text { pessoais (intra) e } \\
\text { sociais (inter) }\end{array}$ & $\begin{array}{l}\text { Ter vontade de atingir a } \\
\text { eficácia em relação aos } \\
\text { conhecimentos ou } \\
\text { habilidades já } \\
\text { desenvolvidas }\end{array}$ & $\begin{array}{l}\text { A unidade do homem. Ética, } \\
\text { como processo direcionador } \\
\text { da evolução. O trabalho de } \\
\text { fixação de costumes. } \\
\text { Assuntos relativos à essência } \\
\text { da moralidade (renúncia e } \\
\text { redenção). }\end{array}$ & $\begin{array}{l}\text { Assuntos relativos a Sociabilidade } \\
\text { (devoção, solidariedade, } \\
\text { sentimento único da unidade, } \\
\text { fraternidade).Tendências positivas } \\
\text { e negativas }\end{array}$ \\
\hline Conhecer & $\begin{array}{l}\text { Sensibilidade para } \\
\text { problemas e valores } \\
\text { sociais }\end{array}$ & $\begin{array}{l}\text { Domínio dos } \\
\text { conhecimentos e } \\
\text { habilidades }\end{array}$ & $\begin{array}{l}\text { A interioridade do ser: } \\
\text { desejos e aspirações mais } \\
\text { secretos. }\end{array}$ & Auto Emoção \\
\hline Planejar & $\begin{array}{l}\text { Novos interesses e } \\
\text { aspirações }\end{array}$ & Tomar decisões & Auto Vontade & $\begin{array}{l}\text { Reconhecimento das } \\
\text { potencialidades que vibra em seu e } \\
\text { em cada Ser. }\end{array}$ \\
\hline Processar & Engajar-se & $\begin{array}{l}\text { Persistência e } \\
\text { Constancia }\end{array}$ & $\begin{array}{l}\text { A afirmação da liberdade no } \\
\text { individuo e na coletividade }\end{array}$ & $\begin{array}{l}\text { Necessidade de compartilhar e } \\
\text { complementar com o exterior. }\end{array}$ \\
\hline Desenvolver & Negociação & $\begin{array}{l}\text { Elaboração de tarefas e } \\
\text { projetos }\end{array}$ & $\begin{array}{l}\text { A superação da insegurança } \\
\text { e do medo através das } \\
\text { realizações }\end{array}$ & $\begin{array}{l}\text { Desenvolvimento da sensibilidade } \\
\text { estética }\end{array}$ \\
\hline \multirow[t]{9}{*}{$\begin{array}{l}\text { Criar } \\
\text { modelos }\end{array}$} & Ensinar & $\begin{array}{l}\text { Busca de qualidade em } \\
\text { processos }\end{array}$ & & $\begin{array}{l}\text { Disponibilizar a criatividade, } \\
\text { vontade e inteligência para o } \\
\text { exterior }\end{array}$ \\
\hline & Colaborar & Abertura à mudança & & \\
\hline & Criar & Atitude de melhoria & & \\
\hline & Superar bloqueios & Atitude criativa & & \\
\hline & Enfrentar conflitos & Flexibilidade & & \\
\hline & $\begin{array}{l}\text { Compreender e } \\
\text { conceber as } \\
\text { diferenças como } \\
\text { complementares e } \\
\text { não como fonte de } \\
\text { conflitos }\end{array}$ & Elaborar materiais & & \\
\hline & $\begin{array}{l}\text { Identificação com a } \\
\text { empresa e com seu } \\
\text { trabalho }\end{array}$ & $\begin{array}{l}\text { Avaliação de Projetos e } \\
\text { Programas }\end{array}$ & & \\
\hline & & $\begin{array}{l}\text { Análise das } \\
\text { necessidades }\end{array}$ & & \\
\hline & & $\begin{array}{l}\text { Aprender com erros ou } \\
\text { com outros }\end{array}$ & & \\
\hline
\end{tabular}

Fonte: "CHAVE" de Macarenco e Zamora

Olhando a moeda com dois lados verifica-se que exterioridade e interioridade coexistem. O "CHA" oferece os elementos exteriores ou objetivos, enquanto que a "CHAVE" oferece os elementos interiores ou subjetivos. Para que o homem desenvolva suas 
potencialidades e seja o melhor do que possa vir a ser, mas sendo ele mesmo, é necessário refletir e analisar sobre os processos emocionais e racionais.

É fundamental que haja uma compreensão das causas que levaram gestores e empregados a criarem uma percepção totalmente alterada sobre vida e trabalho, com a visão única de resultados organizacionais - da moeda com um único lado.

Pouco espaço é criado para se rever essa forma como esse caminho tem sido construído e como é possível, a partir desta compreensão, criar novos rumos para as organizações e as pessoas. A contribuição de Bendassolli (2001) é fundamental para essa reflexão, porque o reconhecimento de que um vocabulário está impregnado por uma cultura não significa um pessimismo aterrador semelhante ao que diz que nada podemos fazer. A consciência de que os vocabulários são contingentes, embora vigorosamente assimilados, nos permite pensar que tal como a Igreja (ou o pensamento religioso em geral) perdeu um dia sua influência devastadora sobre nós, assim também o vocabulário da habilidade e da competência poderá perder a aderência quase asfixiante que tem hoje (caso isso seja, de fato, posto em questão)" [...] "a caracterização de uma sociedade pós-industrial, não são termos isolados, desligados daquele jogo de linguagem que deu origem ao vocabulário das habilidades e da competência (ambos agindo um sobre o outro)". Este último não teria a força que tem exceto se atendesse a certos propósitos, e não seria absurdo dizer que tais propósitos são, entre muitos outros [...] criar, por um lado, um upskilling no mercado de trabalho, fazendo crescer rapidamente e se intensificar agressivamente o nível geral de formação técnico-profissional de carreiras sofisticadas e de ponta. Por outro lado, cria uma maior polarização entre carreiras, pois aquelas onde se exige (ainda) menor formação tende a ter um achatamento nas suas faixas de rendimento. (BENDASSOLLI 2001: 66).

\subsection{3- Dificuldade dos Gestores}

As causas para a dificuldade do gestor de lidar com novos paradigmas devem estar fundamentadas nos princípios clássicos de gerenciamento e nos seus ensinamentos sobre a racionalização do trabalho. Sobre o acesso aos novos conhecimentos e sobre os aspectos contemporâneos da administração sabe-se que eles encontram-se fartamente disponíveis, mas um novo aspecto passa a ser alvo de reflexão: a necessidade de uma mudança interna do indivíduo. Para alterar a conduta e aprender a fazer uso desses conhecimentos, mas com muito mais sabedoria, é preciso alinhar razão e emoção. 
A Figura I apresentada a seguir traz alguns elementos, que associados podem contribuir para que as pessoas abandonem a "falsidade", o conhecimento emprestado e entrem em contato com sua sabedoria e sua própria compreensão.

Figura I - Repercussões do Alinhamento da Razão à Emoção
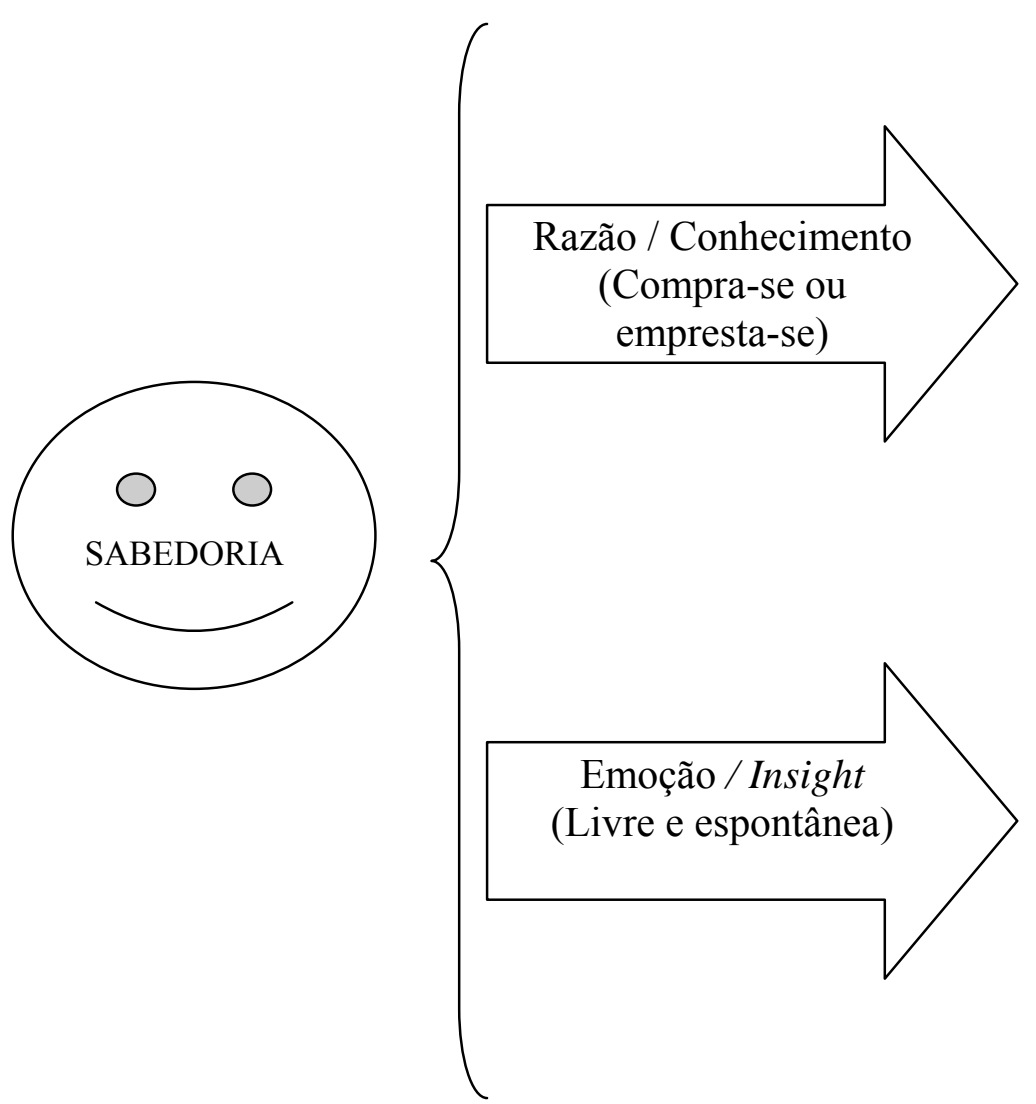

O que o indivíduo está pensando é reflexo da mente envolvida por modelos, crenças e idéias definitivas, e o que ele está fazendo pode refletir um ponto de vista estreito e controlador.

O que o indivíduo está dizendo é o que está comunicando, e o que ele está fazendo pode refletir um sentimento de estar explorando em nome da insatisfação ou satisfação com o que está acontecendo.

Esse alinhamento permite a compreensão de que conhecer e pensar não são verdades absolutas, e que o diálogo com a incerteza será sempre inevitável. O conhecimento "emprestado" é necessário, mas torna-se validado somente quando o homem consegue integrar esse conhecimento aos seus modelos mentais e utilizá-lo na condução de sua própria vida. Se o conhecimento representa saberes acumulados ou empilhados, e se a mente humana não dispõe de um princípio de seleção que lhe dê sentido, então o que prevalece é a "cabeça bem cheia", ou seja, uma memória privilegiada, um chip bastante potente para armazenar muitas informações. A "cabeça bem feita" de Morin (2000) esclarece que, em vez de acumular o saber, é mais importante dispor ao mesmo tempo de: uma aptidão para colocar e tratar problemas; princípios organizadores que permitam ligar os saberes e lhes dê sentido. 
Para tratar problemas é preciso que o conhecimento influencie o aprender a fazer, o aprender a viver junto e o aprender a ser de Delors (1999). Os princípios organizadores é que na prática podem levar a uma transformação do modelo mental, e a partir dessa mudança interna o homem pode aprender a transformar o externo. Essa reforma do pensamento é o que poderá levar as pessoas a usarem a inteligência para responder aos desafios do lidar com a razão e a emoção para fazerem transformações a partir das novas aprendizagens.

O conhecimento por conhecimento, enquanto mero acúmulo de idéias e informações, impede o movimento livre do pensamento, principalmente porque as pessoas podem ser tomadas pelo medo da crítica. Para explorar novas idéias e estar empenhado na exploração de novos fatos, o gestor deve estar interessado em se afastar do velho modelo de gerenciamento, por compreender o quanto este gera mentes preguiçosas, entorpecidas pela autoridade, modelação, controles e condicionamentos. É quando se tem a compreensão de que o velho modelo não pode se manter por si só; surge então o medo da crítica e, a causa está no medo de investigar o valor inerente a um fato, uma experiência ou uma idéia, e ainda, sabe-se que muitas idéias são consideradas apenas quando há uma qualidade atribuída a elas, a possibilidade de alguém tirar um proveito, lucrar ou gerar poder.

O processo de compreensão não vem da mera repetição das idéias anteriormente experimentadas. Assim, o gestor não é instrutor ou um pregador, que traz um auxílio temporário e pontual, que gera um conforto. O gestor poderá causar desconforto, (considerando-se que a idéia central da estrutura social no modo de produção capitalista é o lucro, o desempenho e o sucesso) quando houver espaço para questionar sobre a idéia que se tem de sucesso, de segurança, de lucro e do temor de perder oportunidade.

É um exercício, trata-se de abrir uma brecha para a coragem de explorar novos conceitos e novas formas de relacionamento, não há porque se enganar, mas essa idéia de crescer cumulativamente parece cada vez mais ser uma ilusão, pois na medida que o homem aumenta sua propriedade mais nela se encerra, ou quanto mais aumenta o conhecimento mais pode ser limitado por ele.

\subsection{4- Sobre o Desconforto de Aprender}

De modo geral, no dia a dia, quando as pessoas aprendem fazendo prevalecer uma busca do poder ou até mesmo a sobrevivência, a sedução ou crenças confortáveis, é preciso reconhecer que não há inteligência criadora presente nas suas ações. É do apoio à 
individualidade que nasce a ação baseada na inteligência criadora, sem medo e sem aprisionamento à ilusão, então talvez não se possa auxiliar outra pessoa a desenvolver a inteligência criadora pelos caminhos convencionais de educação e treinamento porque a verdadeira educação não traz conforto.

Quando o indivíduo aprende e cria entendimento da realidade, ele cria também uma preocupação - o de querer melhorar a si próprio, para então poder auxiliar os demais. Aprender implica buscar uma verdade e de modo geral as organizações, nas quais o indivíduo está inserido, estão estruturadas para prover o bem estar físico do homem e não para conduzilo à verdade. Entende-se que a verdade não pode ser encontrada através da organização, de qualquer método ou modelo institucional, mas pode ser encontrada quando o indivíduo, por seu entendimento, puder, com a inteligência de suas competências, responder às novas situações para trazer um novo entendimento nas organizações sobre a forma de perceber a realidade e agir nesse contexto.

Compreender para poder agir refere-se ao exercício da percepção e do entendimento, mas também é uma condição para que se liberte a mente e talvez por tanto tempo deve ter sido essa a razão para se ter tentado manter as pessoas presas aos modelos, à imitação e ao temor.

Verifica-se também o quanto essa verdade é paradoxal, pois assusta os que se descobrem como meros imitadores. Parece então que a mente funciona como um computador, mas antes do computador fornecer uma resposta, um analista deve abastecê-lo, supri-lo de informações, e então ele dará a resposta que provém de um acervo criado. Assim o entendimento é pura inteligência, uma "pessoa de entendimento" investiga as coisas diretamente e torna-se capaz de fazer a ponte entre o objetivo e o subjetivo, de acessar o acervo.

Para Senge (2004) "a complexidade da sociedade acontece numa dinâmica, na qual “causa e efeito" não estão próximos no tempo e no espaço e as intervenções óbvias e conhecidas não produzem mais os resultados esperados. Tornou-se necessário identificar estruturas e padrões de comportamento subjacentes, obscurecidos pelo frenesi dos eventos cotidianos e do incessante excesso de atividades. Aprender sobre esses padrões de comportamento ajuda o indivíduo compreender porque soluções convencionais estão falhando e onde podem ser descobertas ações de maior alavancagem e efeito sobre a complexidade”. É importante verificar que as ameaças básicas à nossa sobrevivência coletiva são acontecimentos que vêm ocorrendo de forma gradual, que surgem de processos complexos, 
tanto em termos de detalhes quanto de dinâmica. Ex. efeito estufa, a destruição da camada de ozônio, a Qualidade de Vida.

$\mathrm{Na}$ mesma proporção o desenvolvimento organizacional, para enfrentar as ameaças básicas, depende do desenvolvimento das pessoas, que por sua vez requer domínio pessoal e aprendizagem, de modo que venha à tona a estrutura de modelos mentais que se orientam pelo formato colaborativo e estímulo a convivencialidade. Tornou-se necessário alterar não apenas o que se pensa, mas as formas de pensar predominantemente.

A evolução da organização depende da evolução da inteligência. Conforme Senge (2004) a disciplina da aprendizagem ocorre quando atinge três níveis: a prática, que representa aquilo que se faz, os princípios, que são as idéias orientadoras e as novas idéias e a essência, que é o estado de ser daqueles que possuem altos níveis do domínio da disciplina.

A documentação de anos da Experiência de Hawthorne revela que o grupo de moças aprendeu a criar os resultados que realmente desejaram, foram estimuladas a desenvolver padrões de pensamentos novos e abrangentes, a aspiração coletiva fez com que as pessoas aprendessem juntas, foi cultivado nelas o comprometimento e a capacidade de aprender. As pessoas funcionavam juntas de forma extraordinária, confiavam umas nas outras, o que ressaltava seus pontos fortes e compensava suas limitações. Prevaleceu um objetivo em comum maior do que os objetivos individuais. Verificou-se que o grupo não começou excelente, mas aprendeu a produzir resultados excelentes.

Sabe-se que nas organizações as pessoas estão presas às fronteiras dos próprios cargos e nem sempre as teorias são praticadas, pois prevalecem a ilusão do controle e a necessidade de ser pró-ativo, como resposta à demanda organizacional, às exigências externas pontuais e aos eventos emergentes.

\subsection{5- Aprender para Ensinar}

Como ser social o sujeito precisa da comunicação e da interação com seus semelhantes. Com a convivência e a experiência o indivíduo desenvolve qualidades humanas, que revelam a capacidade de aprender sobre ter respeito pelo outro e por si mesmo. Observa-se que em gestão não é possível ensinar aquilo que não se aprendeu, então se recomenda aprender sobre convivencialidade para então poder ensinar. 
Sobre essa recomendação sugere-se a reflexão sobre as colocações de Albrecht (2006) que estimulam a elaboração de alguns princípios que podem orientar as ações de administradores de recursos humanos e gestores:

1. Atitudes assertivas e decentes devem ser entendidas "não como vantagens" para o perfil do gestor, mas para a divulgação da decência humana, de quem pode dar exemplo e orientar a convivência;

2. Ao lidar com o "outro" buscar pontos comuns com ele para deixar de reagir em particular;

3. Aceitação da pessoa que se está em contato para que ela também se sinta disposta a aceitar o contato. Muitas vezes, socialmente, usam-se "máscaras" para evitar rejeição do que se pensa ou quem é. Observa-se que o que faz com que alguém tenha estima e respeito pelo outro é a personalidade e suas realizações dele;

4. Convivência com as decepções, não há como exigir demais dos outros ou exagerar nas expectativas em relação ao outro;

5. Prática da conciliação mesmo quando a vitória for certa;

6. Submissão "às regras do jogo", impostas pelo outro ou pelo contexto pode não ter valor construtivo, pois revela acomodação;

7. Autoconfiança para não se assustar pelas dificuldades, para lidar com os próprios pontos fracos e qualidades, para exercitar a auto-avaliação e promover o autodesenvolvimento;

8. Aprendizagem sobre si mesmo e, por conseqüência, sobre o "outro";

9. Permissão negada à perplexidade imposta pelo "outro";

10. Conhecimento das pessoas não apenas para prever comportamentos, mas para saber lidar com elas. O conhecimento da natureza humana representa uma condição favorável de proteção contra as decepções, os erros, o modo de agir e até contra perigos;

11. Não fixação de julgamento precipitado. $\mathrm{O}$ erro está em julgar-se qualificado para julgar sobre a qualidade de um outro ser humano;

12. Nenhum ser humano possui toda a verdade. 
13. Prática da inteligência para pensar antes de dizer algo, especialmente quando se pretende dizer algo que realmente se pensa.

14. Tolerância com a maneira de ser do "outro";

15. Visão das coisas numa perspectiva correta. Sempre é preferível construir a destruir;

16. Aproximação do outro, além do sentido espacial, em termos de contato pessoal. Cria-se a distância como um espaço livre para a privacidade;

17. As palavras são pontes...

18. Aprendizagem com os conflitos;

19. Convívio entre as pessoas, baseado na consideração recíproca;

20. Atenção à sensibilidade para questões humanas, reduzidas pela racionalidade institucional, que se orienta pela consciência de direitos e obrigações.

\subsection{6- Gestores Aprendendo com Administração de Recursos Humanos}

$\mathrm{Na}$ visão de Senge (2004), a verdadeira pró-atividade consiste em perceber qual é a nossa contribuição pela criação e perpetuação de nossos próprios problemas. A teoria do pensamento sistêmico revela que as ameaças às empresas e aos profissionais não estão presentes apenas nos eventos específicos ou processos, mas são resultados de processos lentos e graduais. É assim que a Administração de Recursos Humanos vem se mantendo, talvez buscando modelos para imitar, mas se surpreendendo, o tempo todo, com ameaças e problemas, cujas soluções podem ser pontuais, mas não trabalham a cura dos sintomas pela descoberta das causas anteriormente provocadas.

Diante de situações repetitivas, os profissionais nas organizações parecem se acostumar aos problemas e a cada evento uma espécie de paralisia impede a ação da mudança e da aprendizagem para construção de novas práticas organizacionais.

A Administração de Recursos Humanos pode estar sendo guiada no sentido de identificar processos lentos e graduais e para tanto precisaria reduzir o nível frenético de atividades para prestar atenção tanto aos eventos sutis quanto aos trágicos.

Conforme Senge (2004) prevalece uma ilusão de que é possível aprender com a experiência, por tentativa e erro, mas evita-se o exercício da reflexão sobre as conseqüências 
das decisões importantes. Assim, a tendência para a Administração de Recursos Humanos é uma possível dificuldade com a análise mais importante dos problemas, sobre as questões complexas que atravessam os limites funcionais e que podem ter se tornado um exercício arriscado ou inexistente.

O mito da expertise e da capacidade gerencial da área responsável pelos Recursos Humanos tende a levar os profissionais da área a lutar pelo espaço próprio e não se expor para não parecerem incompetentes. $O$ conceito de Equipe gerencial passa a ser utilizado para manter a aparência de grupo coeso, para abafar divergências, polarizar as opiniões, mas sem revelar as diferenças de pensamentos e experiências de cada um; então pode estar faltando espaço interno para o diálogo e a equipe pode se ver em dificuldades diante de problemas complexos, que são encarados como embaraçosos ou ameaçadores. De modo geral a educação formal não prepara as pessoas para admitir que não saibam a resposta e na maior parte das empresas, há um reforço para que as pessoas não indaguem sobre os problemas.

Entende-se assim que o gerenciamento evita o imprevisível, o espontâneo e o agitado, pois prefere a ordem e a disciplina das estruturas e papéis bem definidos. A reação é compreensível, mas não conduz a parte alguma - afinal a única certeza é a incerteza.

Resguardando sua herança das escolas de Administração, o mundo do gerenciamento tem como base o modelo de controle e da racionalidade da organização, então o gerenciamento para a função de direção tornou-se refratário ao sentimento, emoção e afetividade, de modo que esse universo dá pouco espaço aos aspectos de convivência como contexto de espontaneidade e de idéias inovadoras, com a possibilidade de se mudar os níveis de tomadas de decisões e de solução de problemas, que muitas vezes têm impedido as transformações organizacionais e o alcance de resultados mais abrangentes. Assim as conversas são improdutivas e o sonho e o imaginário considerados ameaças à ordem estabelecida.

Esse mundo da gestão caracterizou-se mais por uma rejeição à reflexão, sendo que o prazer de pensar ou a faculdade de julgar as decisões de modo não convencional são evitados em função dos pensamentos pré-estabelecidos das últimas idéias ou correntes de pensamento em alta. $\mathrm{O}$ costume transforma-se em necessidade e o conformismo reina. 


\section{2- A Comunicação}

A valorização da comunicação, como competência de apoio à Gestão com Pessoas, remete a questões ainda não explicadas em consenso: Como comunicar para que a outra pessoa compreenda? Como escutar com compreensão ou como ser ouvido com compreensão?

Nesse sentido, a própria comunicação passa a ser compreendida como uma mudança do fato a ser comunicado. Essa mudança ocorre quando uma idéia, do ponto de vista de alguém, num determinado espaço e tempo, é disparada em direção a outras pessoas que têm outros pontos de vista, num outro espaço, e que deve ser duplicador dessa idéia na prática. Esse novo fluxo está representado na Figura II.

Figura II- Fluxo de Comunicação

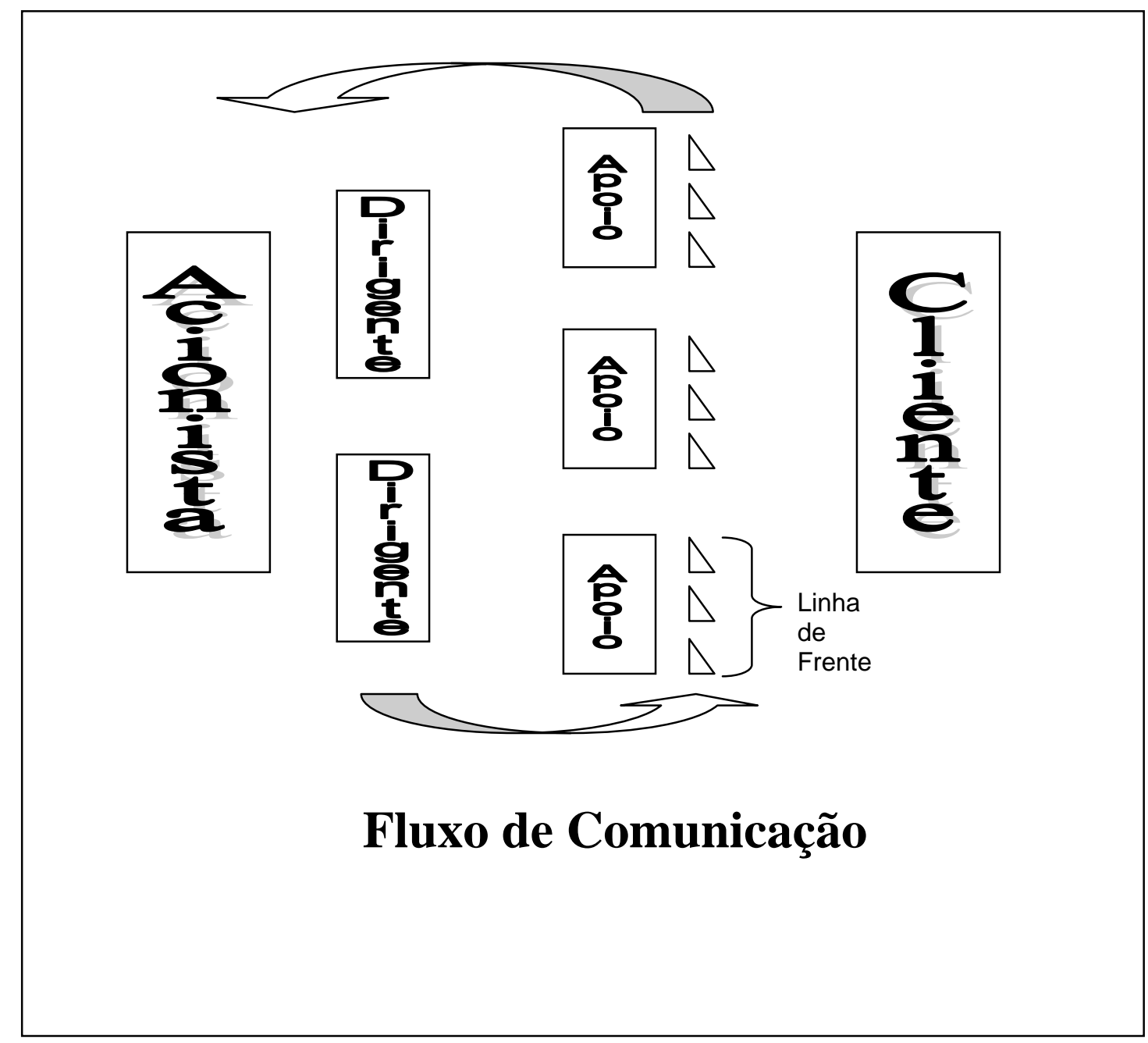




\subsection{1- Comunicação Para uma Idéia Com os Demais}

Considerando-se que a realidade dos fatos é relativa, isso também deve ser discutido e compreendido. Para tanto é importante refletir que a comunicação, em Gestão COM Pessoas, passa a ser compreendida como a ação Para promover uma idéia ou palavra do ponto de

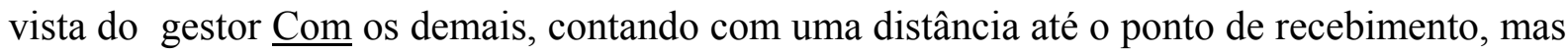
com a intenção declarada de criar nas pessoas - o ponto de recebimento - uma perspectiva de compreensão e de duplicação da mensagem enviada.

A duplicação da comunicação é que pode facilitar na implantação do Princípio da Convivencialidade e sugere "entregar" elementos para que as pessoas possam ter maior clareza e compreensão sobre o significado daquela idéia, em uma tentativa de se construir uma realidade comum, mesmo que haja diversidade de opiniões.

A comunicação serve para o Gestor e Pessoas perceberem a importância de se compartilhar uma visão, que também favoreça a possibilidade da criação de uma realidade que aumente a afinidade entre as pessoas. Para poder comunicar sobre novos paradigmas é fundamental que o conceito de Convivencialidade dê o suporte para que gestores experimentem novos paradigmas.

Gestor com Pessoas precisam estar preparados para serem duplicadores de idéias e também precisam estar dispostos a serem duplicáveis no ponto de recebimento, porque cada um passará a prestar atenção nas pessoas para que suas idéias sejam compartilhadas, ouvidas, compreendidas, respondidas e gerem novo compartilhamento, audição, compreensão e nova resposta. Gestores com Pessoas enquanto pontos de recebimento devem ser preparados e estarem dispostos a se tornarem um ponto de formulação de respostas.

Entende-se que o fluxo da comunicação passa a ser compreendido como um entrelaçamento de pontos de formulação de uma idéia ou fato e de respostas, ao mesmo tempo em um continuum. É importante muita lucidez nessa hora, uma vez que se trata de uma idéia a ser compartilhada e não de uma técnica mecânica a ser adotada para gerenciamento.

Os novos parâmetros de relacionamento introduzidos pela Convivencialidade é que podem favorecer essa perspectiva de construir um nível de disposição necessário aos Gestores com Pessoas experimentarem novas posições no fluxo da comunicação: ser ponto de duplicação da comunicação e ao mesmo tempo ser duplicável nas suas idéias.

Será algo a ser testado no futuro, mas se essa disposição estiver no presente de indivíduos e grupos, as pessoas poderão, cada vez mais, sentir-se igualmente participantes de 
uma engrenagem econômica, como seres vivos, conectados e abertos para experimentarem a comunicação como uma competência para uso próprio e ao mesmo tempo como um elo entre pessoas, promovendo afinidade e visão compartilhada sobre uma realidade que apenas "aparenta ser", cada qual em uma posição que pode se alterar o tempo todo, com novas compreensões dos fatos, novas duplicações de idéias e, acima de tudo, na busca de estar em equilíbrio.

Esta reflexão deve trazer para Gestores COM Pessoas uma indagação sobre o porquê eles costumam comunicar sobre coisas que são impostas a todos, por causas externas aos seres e como cada um pode estar esperando que uma fonte exterior lhe dê um motivo para haver uma comunicação. Quando a comunicação é tratada como uma competência de apoio ela pode ser analisada no seu duplo aspecto de construção e destruição, de extremos que se tocam e revelam que tudo existe e não existe ao mesmo tempo.

Coisas que aparentemente são opostas podem revelar uma questão de graus de dificuldade para lidar com elas. Nas organizações, Gestores COM Pessoas tendem a serem considerados fracos em originar comunicação ou criar alternativas para tomada de decisão, mas pode-se facilmente verificar que tais pessoas, dependentes de impulsos externos, sem conexão com a realidade, sem busca de afinidades com os demais, podem atingir níveis extremos de outros tipos de atitudes: oscilam entre compulsividade ou inibição, entre conversa amistosa ou sentimentos hostis ou entre o desconhecimento do próprio potencial e das limitações.

\subsection{2- Comunicação como Competência de Apoio}

De modo geral considera-se que o princípio da existência é a sobrevivência. Então a sobrevivência passou a ser compreendida como meta da vida e o homem é motivado para sobrevivência. Com os ensinamentos das Teorias da Administração tudo que foi aprendido sobre a teoria das Hierarquias das Necessidades de Maslow parece ter reduzido o enquadramento do ser humano à necessidade de sobrevivência, mesmo porque parece que o homem desaprendeu sobre pensar ao longo das últimas décadas.

Hoje a administração utiliza a comunicação como um meio para moldar as pessoas às novas necessidades organizacionais e não para fazê-las pensar, observa-se então com isso, que pode ter acabado de se destruir uma parte de sua personalidade e de sua ambição. 
Os princípios de Gestão descuidaram do desenvolvimento da habilidade do homem em entender o próprio homem, apesar de que a superioridade do homem está na sua capacidade de pensar. A mente é o instrumento básico para a sobrevivência humana, mas poucos estudos sobre a mente evoluem, enquanto as pessoas estão expostas à destruição das outras pessoas, são muitos os fatos sociais que vêm sendo observados e que expõem cada vez mais as pessoas nos mais diversos ambientes e em situações de tomada de decisão.

Até algumas décadas, como não havia outra necessidade, as pessoas precisavam apenas distinguir o certo do errado e decidir sobre o verdadeiro e o falso. $\mathrm{O}$ importante sempre foi manter o controle, por isso todas as ciências visaram estudar o homem e a natureza como um tubo de ensaio para seus objetivos científicos.

É preciso verificar o quanto falta à ciência da comunicação para que ela funcione como uma linguagem básica para a compreensão das idéias, para fazer com que o homem aprenda sobre utilizar a comunicação como uma competência para o próprio desenvolvimento, pois a comunicação como competência de apoio pode contribuir para:

o Servir como bússola para metas e organizações do pensamento;

o Servir como uma fonte de respostas para tanta disfunção;

o Trazer elementos para evidência científica sobre o fundo funcional da mente;

o Considerar a "Arte de Aplicar” a comunicação.

A comunicação como competência de apoio pode orientar profissionais no sentido de gerar idéias e concebê-las com uma intenção: que elas possam ser duplicáveis. É a intenção que comunica, não as palavras. A intenção é sempre nova e comunicada em tempos presentes.

Com essa visão de Administração de Recursos Humanos, apoiada na competência da comunicação, surge uma oportunidade para uma revisão dos padrões de convivencialidade e relacionamento, começando por sua área interna de organização, objetivando ser o "espelho" para os demais. O foco está centrado na comunicação com um propósito: comunicar conforme a realidade, comunicar com intenção.

Conforme Marras (2000) formar "espelhos" e posicioná-los como agentes multiplicadores dentro da organização tem sido uma preocupação da gestão estratégica de Recursos Humanos há muito tempo. É hora da própria área de Recursos Humanos espelhar os paradigmas para assimilação de crenças e valores organizacionais necessários para valorização das pessoas como talentos organizacionais. Gestão COM pessoas, passa a 
incorporar melhorias partir do aumento da capacidade das pessoas confrontarem e comunicarem o aumento de percepções. Esses ganhos podem estimular nas pessoas o desejo de aperfeiçoar a competência de comunicação, a partir da sua compreensão.

Ao revelar-se como espelho para os demais, as ações da área de RH estarão orientando gestores e orientadas para:

o - Ser reconhecida como realizadora;

o - Promover alianças para servir à causa da convivencialidade;

o - Comunicar para ganhar visibilidade de causa;

o - Auferir créditos por suas conquistas;

o - Contribuir para convivencialidade geral;

o - Desenvolver-se continuamente;

o - Ter um plano para a expansão na organização sobre suas novas funções;

o - Ter opções para desenvolvimento de seu trabalho atual;

o - Ter opções para desenvolvimento de suas atuais equipes e

o - Afastar profissionais que não compreendam a causa da área.

A Figura III representa a Roda da Comunicação e os elementos que podem apoiar a Administração de Recursos Humanos em comunicar a idéia dela ser o "espelho" para os demais.

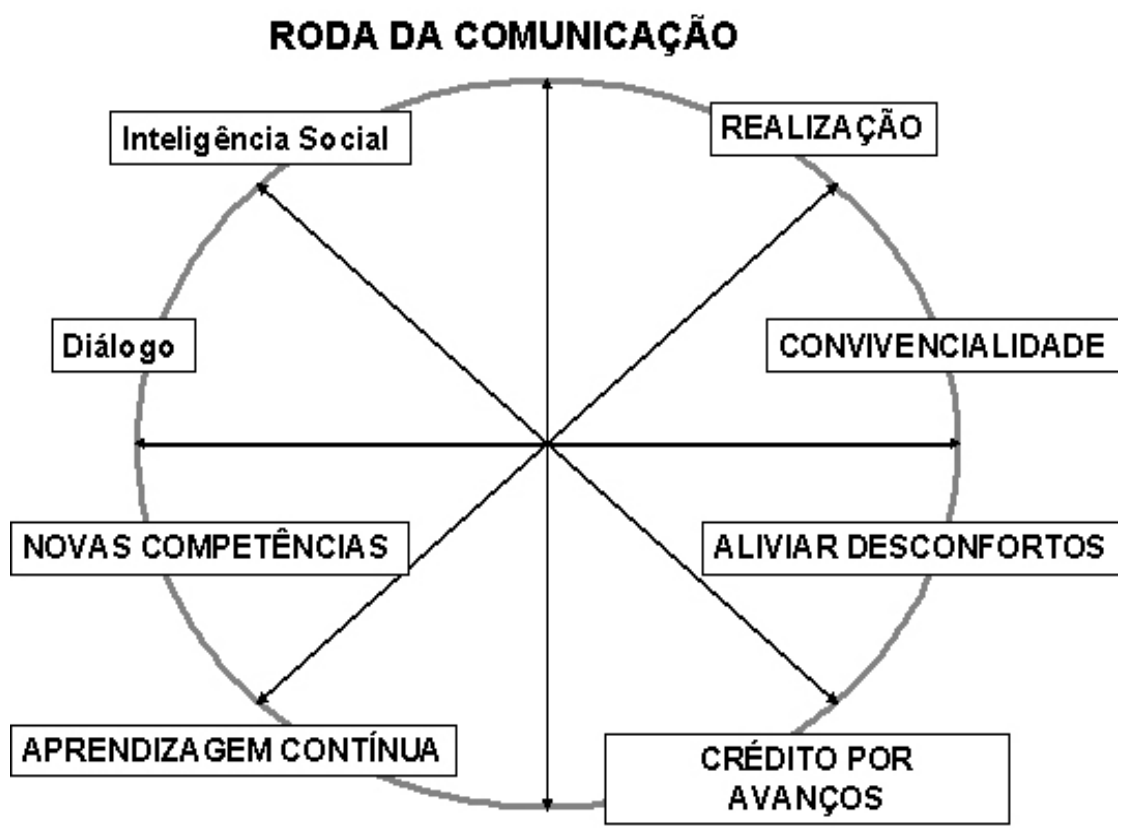


Para entender a roda é preciso considerar que diante da perspectiva de mudanças as pessoas tendem a avaliar a situação com base em um raciocínio linear de pensamento, como se não houvesse necessidade de novas aprendizagens e as velhas crenças fossem suficientes. A roda permite a constatação de que existem novos caminhos e novas aprendizagens e que ao girar não haverá como fazer tudo igual sempre. A roda quebra o ciclo da rotina e do hábito e mostra que vários componentes podem influenciar os participantes da comunicação a serem encorajados a fazer algo fora da rotina e do "círculo vicioso".

\subsection{3- Convivencialidade Aplicada}

Preparar-se para a convivencialidade sugere uma reflexão sobre si próprio e sobre aqueles com quem se convive. É sabido que conviver tornou-se um grande desafio quando se compreende o ser humano como corpo, mente, alma e emoção interligadas.

Para conviver estimula-se a "troca" entre as pessoas e é por meio da troca humana que cada um expande seu potencial e sua inteligência - é o processo de aprendizagem. Com a convivência percebe-se que o próprio referencial não é único e que o "outro" pode ter diferentes referenciais para encarar a vida, os problemas e necessidade de aprendizagem. A convivência pode despertar para a compreensão de que cada um tem capacidades a serem "exploradas" e limitações a serem "encaradas" e que quando se procura "ser humano" estruturado em si, há uma melhora na qualidade de vida, que pode influenciar os demais com quem se relaciona.

Usualmente convivemos com pessoas, situações, problemas e dificilmente nos preocupamos com o sentido do termo convivência. O termo faz parte do nosso dia-a-dia e em consulta ao dicionário Michaelis (2005) verifica-se que "conviver" significa ter convivência, ter intimidade, viver com outrem - uma revelação da complexidade de estar buscando conviver bem com os outros e conosco.

Quando se considera a complexidade dos ambientes de trabalho, da diversidade de pensamento das pessoas, das pressões que cada um sofre, do clima organizacional que influencia a ação das pessoas, todo esse desconforto ou tensão, possivelmente são analisados como algo que acontece externamente ao indivíduo. Pouco se pensa sobre si próprio ou sobre dificuldades ou facilidades para conviver pessoas, jogos de interesses, poder, dentre tantos outros. 
De Masi (2000) observa que os valores da sociedade pós-industrial são a intelectualização, a desespecialização, a feminilização, a desestruturação do tempo e do espaço, a importância crescente dada à qualidade de vida. Enfim, pede uma organização empresarial totalmente diferente do que se tem hoje. Pede um Ser Humano mais estruturado em si mesmo, mais de acordo com sua natureza, inteiro e vivo.

Nesse sentido "ser convivencial", conforme Rocha (2002), provoca uma revisão de postura diante da vida, obriga todos a pensarem sobre a materialidade da vida e sobre reagir diante da automecanização; instiga a desenvolver a inteligência emocional, pois se entende que há um sentido de "pertencimento" ao "conjunto maior". Ser convivencial é aprender formas de usar melhor a mente, cuidar do tempo, do espaço físico, do espaço de cada um e do clima favorável.

As mudanças levaram o ser humano a uma linha divisória na questão da rotina ou da flexibilidade. A flexibilidade está na capacidade do indivíduo de pensar, sentir e agir como ser humano mais "plugado" com essa nova sociedade. Investir na convivencialidade implica conversar com outras pessoas sobre o tema, sobre a ausência de laços humanos, que ameaça o funcionamento de qualquer empreendimento coletivo.

Propõe-se, portanto, cuidado especial com as pessoas que trabalham juntas, com o ato de comunicação, o que é mais importante não são os fatos a serem comunicados, mas as idéias, em um campo de jogo da conversa que precisa ser aberto e acessível, com o estímulo aos profissionais para que eles possam se posicionar como seres pensantes plenos, inclinados a levar para dentro da organização uma concepção moderna de gestão de pessoas e que cada um possa ensinar ao outro o que sabe e o que não sabe, porque está aberto às novas aprendizagens.

\subsection{4- Interação pelo Diálogo}

Culturalmente, aquilo que se conhece com o nome de diálogo é uma interação verbal a discussão/debate - em que os participantes defendem posições, argumentam, negociam e eventualmente, chegam a conclusões ou acordos. O termo “diálogo" já está consagrado pelo uso comum, mas é necessário buscar formas de diminuir as confusões derivadas dessa falta de adequação do termo. Nesse trabalho o diálogo é utilizado como parte do contexto da convivencialidade e representam uma atividade cooperativa de reflexão e observação da 
experiência vivida, cujo propósito é exercitar novos modos de ver e criar significados em conjunto.

O diálogo na convivencialidade é entendido como um meio de promover a confiança e a colaboração. Para Bohm (1998), o diálogo é um processo de comunicação em grupo, no qual pessoas em conjunto criam um curso de significados compartilhados, que lhes permite se entenderem e compartilharem uma visão do mundo. As pessoas podem começar uma comunicação em pólos opostos, mas ao conversar abertamente, podem descobrir terrenos comuns, questões comuns e metas compartilhadas, sobre as quais podem construir um futuro melhor. O diálogo contrasta-se com a discussão, que objetiva transmitir os pontos de vista de uma pessoa e persuadir os outros a adotá-los. Na discussão o oponente é derrotado e no diálogo os participantes deixam um pouco de lado suas convicções para ter um nível mais elevado de escuta. Para Daft (2005) o foco está em revelar os sentimentos e buscar construir um terreno comum e esperam do diálogo uma unidade em grupo, um significado compatível e opiniões transformadas.

É importante observar que para Mariotti (2000) a ciência ensinou que fragmentar é mais forte que a necessidade de integrar e as pessoas têm dificuldade de escutar até o fim algo que está sendo dito e passa a fazer uma comparação com outras pessoas e a fazer referenciais prévios. Esse processo mental de automatismo concordo-discordo tem levado as pessoas a trabalharem em extremos, o que é muito limitante porque não atinge o pouco conhecido ou o desconhecido e com isso o processo mental passou a ser condicionado pelo automatismo da lógica do ou/ou a lógica binária do sim/não. Na reflexão do autor o principal objetivo do diálogo é lidar com o automatismo concordo-discordo e tentar diminuir esses condicionamentos e buscar alternativas à atitude habitual.

Dessas observações é possível inferir que a principal utilidade do método dialógico é perceber e pensar as mesmas questões de modos diferentes, a fim de que daí possam emergir idéias novas e num segundo momento, por meio da discussão e do debate, estas poderão ser avaliadas, julgadas, o que pode resultar em novas perspectivas de ação não-repetitiva, diferente das rotineiras que podem estar cercadas das dificuldades e fracassos.

Entende-se que o questionamento básico do diálogo é simples e pode ser compreendido como uma "suspensão temporária" para as 'certezas' ou seja, aprender a mudar o modo de olhar, modificar a perspectiva, observar a partir de outros ângulos, pensar os mesmos problemas de modo diferente. Percebe-se que o método dialógico se aplica a qualquer contexto no qual seja necessário produzir idéias não-rotineiras e aprender em grupo. Ele pode ser útil em diversos 
setores e em diferentes oportunidades nos quais se torna necessário variar o modo habitual de perceber o mundo. A área educacional e o universo das empresas são dois desses domínios.

Para Mariotti (2000) são considerados pontos decisivos para o diálogo, como instrumento de busca de idéias novas e, portanto, de conhecimento e aprendizagem:

- Eliminar obstáculos gerados pelo fato de que as pessoas quase sempre definem o seu comportamento a partir de referenciais habituais e já consolidados, que acabam se constituindo no principal bloqueio à percepção e ao aprendizado.

- Observar que a cultura científica formatou um modelo mental fragmentador e como conseqüência aprendeu-se sobre uma visão de mundo voltada predominantemente para fora, isto é, na busca constante da objetividade, como se o conhecimento pudesse ser exclusivamente objetivo. Como conseqüência há um temor de se tratar sobre subjetividade, pois parece algo irrelevante para conhecê-lo, enquanto se aprende mais sobre conhecer para pensar em termos de causalidade imediata.

- Considerar que o aprendizado eficaz depende do modo como se aprende a questionar as idéias previamente concebidas, para que o resultado seja uma abertura mental, tão necessária para a diminuição da resistência à mudança.

Nesse sentido, reconhecendo-se o homem como um ser capaz de pensar, sentir e agir, entende-se que o pensar faz parte da mente e a mente faz parte do cérebro. O cérebro faz parte do corpo. O corpo faz parte do mundo, logo, a mente não é separada do mundo.

A realidade de um indivíduo é a visão de mundo que sua estrutura mental the permite perceber num dado momento. Tal estrutura muda continuamente, de modo que essa compreensão, que num dado instante parece fora de dúvida e definitiva, pode não ser assim mais tarde. Enquanto permanecer apenas individual, qualquer compreensão de mundo tende a ser precária e por isso, é preciso ampliá-la e quanto mais as pessoas conversar sobre suas percepções então as compreensões serão melhores. Observa-se que quanto maior for essa diversidade de pontos de vista das pessoas, melhor ainda será para a convivencialidade e para a perspectiva de dar atenção aos pontos de vista dos quais mais se discorda. Definitivamente não se trata de aceitar tudo ou concordar com tudo, significa que com a diversidade ampliam as possibilidades de aprendizagem e de abertura da mente. 


\subsection{5- Construção do Tripé: Realidade, Afinidade e Comunicação}

A comunicação como competência de apoio deve trazer um avanço para a aprendizagem e questões de convivencialidade e os gestores COM pessoas poderão estimular a descoberta de novos caminhos para reconhecer a capacidade das pessoas de pensar, sentir e agir, considerando alguns aspectos novos na sua própria aprendizagem:

a. Pensar: para o homem a realidade é aquilo que aparenta ser, mas sobre ela é fundamental que haja um acordo, porque aquilo que se acorda ser real é o real. O homem pensa com base na sua percepção e seu conhecimento, então ele constrói uma realidade. Entende-se que a realidade do mundo físico é percebida através de vários canais: com os olhos, com os ouvidos, com as mãos, com o nariz e então, decide-se que algo existe, que é real. O mundo é conhecido através dos sentidos: visão, audição, tato, paladar e olfato. O sentido é um canal artificial, pois não se contata o universo físico, mas todos estão em contato através de canais sensoriais. Assim cada pessoa tem uma realidade diferente daquela que a outra captou com seus sentidos e quanto mais uma pessoa concorda com uma realidade mais elas entram em comunicação. Para um indivíduo, a realidade pode consistir nas interpretações das percepções sensoriais que ele recebe, mas a realidade difere em detalhes, segundo cada observador, logo pode haver diversos relatos sobre o mesmo fato. Na verdade, existe uma extensa área de acordo, o acordo comum da humanidade: terra, homem, água, ar, sol, céu. Se a realidade consiste na percepção pessoal da realidade então a realidade consiste naquilo que se pode pensar e comunicar PARA outras pessoas.

b. Sentir: o homem sente, a partir de sua afinidade com pessoas e objetos. Então a afinidade corresponde à resposta emocional. Trata-se do sentimento de afeição ou da falta dele, de emoção ou não-emoção, que estão conectados com uma área da vida. Afinidade implica em uma maior ou menor distância com relação a algo ou alguém, corresponde ao grau de estima e de interesse por pessoas ou objetos, mas isso não significa identificação com a presença de um só sentimento, vai além de empatia. Afinidade não implica obrigações, mas há uma aproximação, uma influência animadora, pois as pessoas envolvidas concordam sobre uma realidade e são capazes de comunicar esta realidade entre si.

c. Agir: o homem age quando se comunica e muitas vezes a comunicação parece uma química para todas as coisas e essa química requer acordo e afinidade, e para haver 
uma realidade e um acordo, deve existir afinidade e comunicação. Entende-se que se não houver comunicação todas desaparecem. A afinidade pode ser aumentada de diversos modos, no caso da convivencialidade conversando com as pessoas. Quando se consegue fazer com que as pessoas entrem em acordo, comunicação e afinidade aumentarão; quando uma equipe está de acordo em relação ao que está fazendo então está se comunicando.

A Gestão, Comunicação e Pessoas, apoiada no tripé realidade, afinidade e comunicação pode elevar a afinidade das pessoas para discutir idéias básicas como aprendizagem e desenvolvimento de competências no sentido de aumentar a percepção do cenário que se vive. Tratar de Gestão COM Pessoas implica elevar o nível de necessidade do indivíduo para além da necessidade de sobrevivência e efetivar uma intervenção para estimular acordo sobre novas perspectivas humanas. Entende-se nesse estudo que gestão e pessoas coexistem e que a afinidade, o acordo sobre a compreensão da realidade e a comunicação podem fornecer o apoio para o desenvolvimento da convivencialidade e do diálogo. Em ambiente de ignorar ou não aplicar estes conceitos pode estar levando pessoas a se envolverem em conflitos, sofrimento, apatia e não motivação, simplesmente, em razão da falta de compreensão de idéias básicas para enfrentar novos contextos. Acredita-se que a melhor maneira de comunicar sobre essas idéias é fazer com que as pessoas acreditem que há algo dentro delas que pode ser apreciado pelos demais e que elas podem discutir sobre isto.

\section{3- Gestão COM Pessoas}

Gestão COM Pessoas refere-se à gestão apoiada na competência comunicação para promover pessoas ao desenvolvimento humano e abrir espaço para a figura do sujeito e para $\mathrm{o}$ aspecto da convivencialidade.

Se a comunicação é entendida como linguagem básica para que “idéias" sejam entendidas, então a figura do sujeito está ao lado da imaginação, da criação, da crítica e da reflexão sobre si mesmo; ele participa da transformação do mundo, ele é o criador da história quando tem consciência de sua fragilidade, da experiência vivida, do simbólico, da história e da ética. Visto como pessoa pode ser um cidadão, um profissional, um ocupante de um cargo de direção, um funcionário ou um trabalhador; é um ator social que conhece as normas e as regras a serem cumpridas na esfera social e na vida privada; desenvolve expectativas em relação ao seu comportamento, do outro e vice-versa. Visando a sua aceitação a pessoa 
aprende a observar as regras aplicáveis ao jogo de cada momento, regras para diversos jogos sociais e para o alcance do melhor resultado.

Gestão COM Pessoas é uma idéia nova e sabe-se que a ruína da maioria das idéias novas é que não se discute esses assuntos com as outras pessoas salvo quando há algum ponto de acordo, discute-se sobre aquilo com que se concorda, pois a tendência é que algo que esteja mais próximo da realidade de alguém seja mais real do que aquilo com o qual não se concorda. Para o aprimoramento de um modelo de Gestão COM Pessoas verifica-se que uma correlação necessária entre acordo e realidade, pois parecem ser reais, as coisas que se concorda serem reais. O diálogo pode levar a um acordo. Para se discutir assuntos novos com as pessoas torna-se necessário construir e estabelecer a realidade começando por tentar descobrir alguns pontos com os quais estas pessoas concordem. Para os gestores é importante procurar manter o nível de afinidade com a perspectiva de poder se comunicar com os demais, sob a ótica da convivencialidade, pois o objetivo é combinar elementos do tripé realidade, afinidade e comunicação para estimular a compreensão.

É por meio da compreensão que uma pessoa pode se fazer entendida, combinando afinidade, realidade e comunicação. Esse pode ser um caminho para que Gestores COM Pessoas sintam-se menos impotentes ao tratar com os outros - seja para criar novas relações, manter boas relações ou reparar aquelas que se desviaram.

Figura IV- "Modelo em Construção" para Gestão COM Pessoas

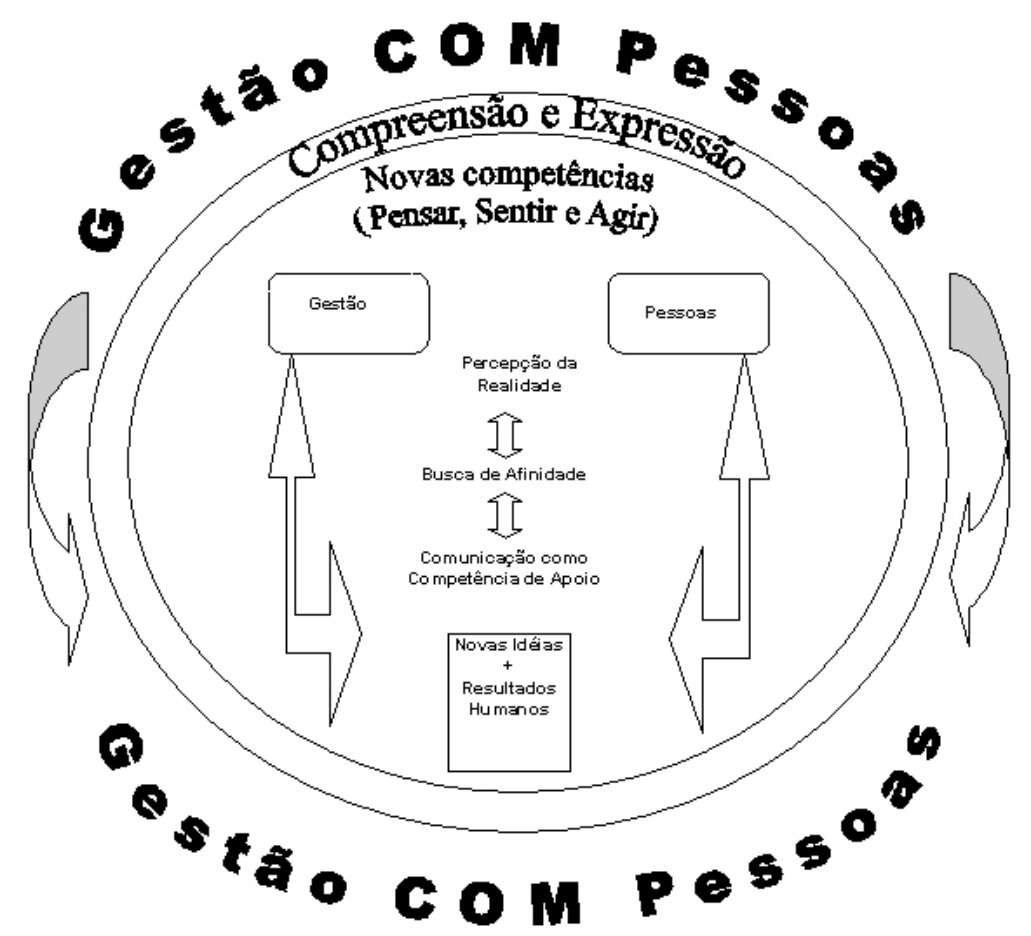


Faz parte da representação do modelo conceitos já desenvolvidos durante o trabalho e que aqui tomam uma forma que representa mais do que uma visão, mas também uma postura da autora perante a vida pessoal e profissional:

Compreensão e Expressão: é o denominador comum de todas as atividades da vida.

Compreensão: é referente à percepção que se constrói da realidade, o nível da afinidade e da capacidade de se comunicar; Expressão: é o mental abstrato se manifestando a partir das idéias de convivencialidade e compartilhamento de aprendizagens.

Novas Competências: são relativas às capacidades de pensar, sentir e agir e referem-se aos conhecimentos, habilidades e atitudes do SER TOTAL.

Gestão: é uma ação para a qual há menor grau de previsibilidade sobre o resultado do processo a ser gerido; o processo está em contínua transformação e depende de fatores humanos e aspectos técnicos.

Pessoas: são os seres em comunicação que existem dentro de um contexto e em um espaço temporal, que constroem a realidade a partir da percepção e da aprendizagem e cujo desenvolvimento pessoal e profissional envolvem competências técnicas, comportamentais e abstratas (Vontade e Expressão).

Percepção é uma construção ativa e implica interpretação.

Realidade é fundamentalmente um acordo sobre o que se concorda ser real e corresponde ao grau de acordo alcançado por pessoas.

Percepção da Realidade: é o processo de organizar e interpretar dados sensoriais recebidos para desenvolvimento da consciência do ambiente e de si próprio.

Busca de Afinidades: é uma atitude emocional e implica "grau" de gostar ou desgostar, estar em maior ou menor distância das pessoas ou idéias. 
Comunicação como Competência de Apoio: é compreendida como apoio em uma ação para promover uma idéia ou palavra do ponto de vista de uma pessoa com as demais, contando com uma distância até o ponto de recebimento, mas com a intenção de criar nas pessoas uma perspectiva de compreensão e de duplicação da mensagem ou da idéia.

Novas Idéias + Resultados Humanos: Novas idéias são as fontes de respostas para disfunções presentes e para construir novas formas de organizar o pensamento, em pessoas confiantes nas suas vivências e no seu potencial para desenvolvimento;

Resultados Humanos - RH é o resultado obtido porque houve um estímulo para as pessoas desenvolverem a capacidade de viver em um mundo totalmente revolucionado e carente de Inteligência Social. Indicadores de RH podem referir-se aos níveis que uma pessoa apresenta nas suas ações quanto a: abertura; autenticidade; anseio pela inteireza; atitude e autoridade Interna.

Abrahamson (2006) afirma que um mal que acomete um número cada vez maior de organizações é a síndrome da mudança repetitiva, cujos sintomas são sobrecarga de iniciativa, caos decorrente de mudanças e cinismo, desgaste e ansiedade entre funcionários. Como resultado além de causar sofrimento às pessoas, em todos os níveis da companhia, torna as mudanças organizacionais mais difíceis de administrar, mais caras para serem implementadas e aumenta a probabilidade delas fracassarem, como também interferem nas rotinas operacionais. Considera-se que Gestão COM Pessoas pode ser um ideal de mudança sem dor, mas com compreensão.

O cientista comportamental Kurt Lewin certa vez ensinou: "Não existe mudança sem sofrimento" e talvez essa seja mais uma herança do gerenciamento. Então se propõe a partir deste estudo que essa sobrecarga seja diluída com abordagens melhores para se aprender sobre mudanças, porque aquilo que as pessoas compreendem é o que se torna realidade, algo que ao ser recriado pode gerar menos sofrimentos e mais resultados, sejam organizacionais ou humanos. 


\subsection{1- Responsabilidade por Resultados Humanos}

Para efeito desta tese, o Índice de Desenvolvimento Humano (IDH) ${ }^{3}$, que é uma medida comparativa de pobreza, alfabetização, educação, esperança de vida, natalidade e outros fatores para avaliar o nível de desenvolvimento de diversos países do mundo, foi tomado como um parâmetro para dar início a uma reflexão sobre possíveis indicadores de Resultados Humanos nas Organizações.

Considerando-se que uma primeira busca de indicadores de desenvolvimento humano aplicado às organizações, possa estar atrelada ao IDH, verifica-se que o desenvolvimento das competências agrega valor social ao indivíduo, numa escala evolutiva, pesquisando-se como se apresentam os níveis de educação, condições para a longevidade e sustentabilidade financeira dos funcionários de uma organização.

Para a Administração de Recursos Humanos alcançar Resultados Humanos - RH é indispensável estimular as pessoas a desenvolverem a capacidade de viver em um mundo totalmente revolucionado e carente de Inteligência Social. Para futuras verificações são propostos os seguintes indicadores de RH:

- Abertura. As pessoas possuem uma abertura para o mundo - tanto interior quanto exterior. Estão abertas à experiência, a novas maneiras de ver, a novas maneiras de ser, a novas idéias e conceitos.

- Autenticidade. As pessoas que valorizam a comunicação como uma maneira de dizer as coisas como elas são. Rejeitam a hipocrisia e ambigüidade como parte da cultura.

- Anseio pela inteireza. As pessoas que não gostam de viver num mundo dividido em compartimentos. Acreditam na totalidade do ser, integram as suas experiências as capacidades de pensar, sentir e agir.

- Atitude. As pessoas sentem-se próximas aos ambientes e às pessoas. São adeptos da sustentabilidade e acreditam na perspectiva do equilíbrio e não da dominação.

- Autoridade Interna. As pessoas confiam em sua própria experiência, acreditam no seu potencial e conhecem suas limitações.

\footnotetext{
${ }^{3}$ Índice de Desenvolvimento Humano (IDH) é uma medida comparativa de pobreza, alfabetização, educação, esperança de vida, natalidade e outros fatores uma maneira padronizada de avaliação e medida do bem-estar de uma população, especialmente bem-estar infantil. O índice foi desenvolvido em $\underline{1990}$ pelo economista paquistanês Mahbub ul Haq, e vem sendo usado desde 1993 pelo Programa das Nações Unidas para o Desenvolvimento em seu relatório anual.
} 
Os indicadores que podem ser considerados para medir os Resultados Humanos alcançados pelas pessoas, a partir de uma ação renovada da área de RH e dos gestores são apresentados na Figura V.

Figura V- RH como Resultados Humanos

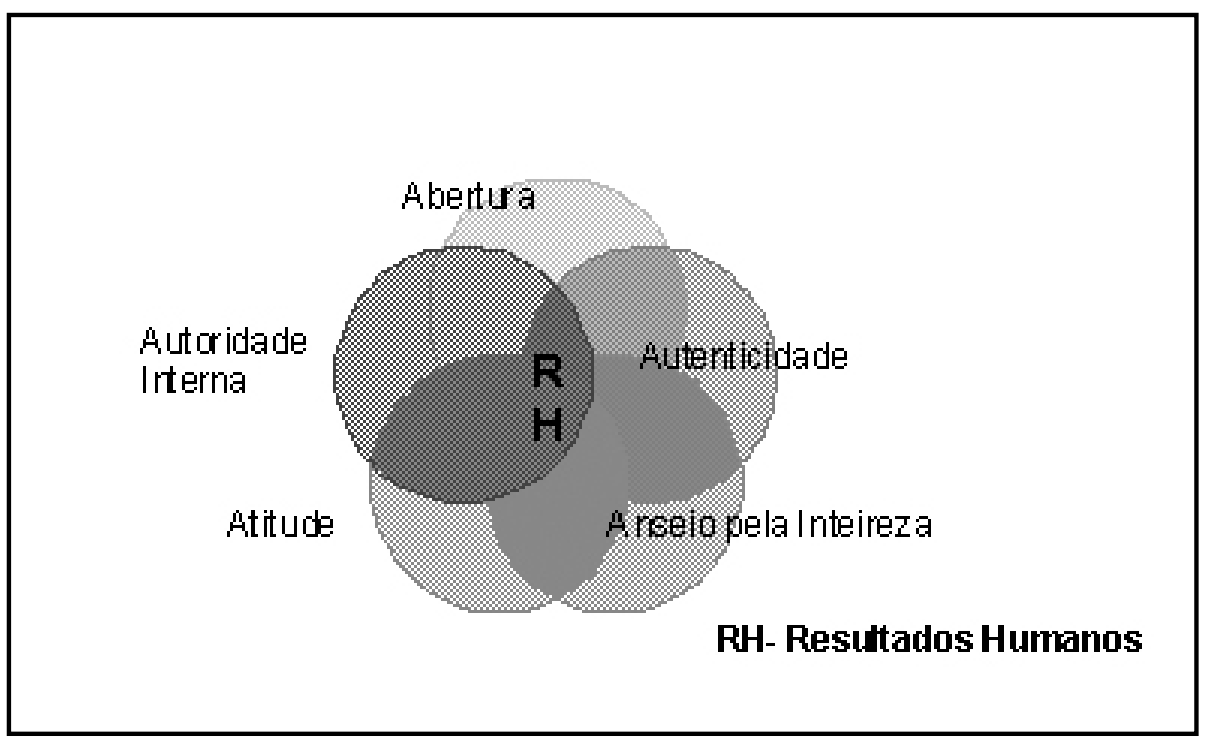

Uma visão mais esclarecida sobre alcançar RH - Resultados Humanos, além dos resultados econômicos almejados pelas organizações, requer uma re-adequação das idéias e conceitos no contexto da vida e de trabalho, e o que se pretende estimular é que o trabalho também seja considerado uma oportunidade de transformação para os seres humanos, sob o aspecto social.

Nesse sentido é preciso que a estrutura organizacional seja repensada, que critérios de designação de pessoas às funções sejam revistos e que o aspecto emocional do trabalho seja uma questão melhor elaborada pelos administradores. Todos esses aspectos dizem respeito à forma como foram feitas as projeções das funções nas estruturas organizacionais tradicionais e como a função que cada pessoa exerce hoje pode estar sendo encarada como algo apenas suportável. Ao revelar sobre esse aspecto emocional do trabalho entende-se que os profissionais já presentes na organização devem aprender a conhecer sobre suas capacidades e limitações, para buscar o próprio desenvolvimento. 


\subsection{2- O Trabalho Emocional na Administração de Recursos Humanos}

Como estudioso da prestação de serviços e qualidade no atendimento, a descoberta do trabalho emocional é de Albrecht (1992:118) e ele afirma que "os estudiosos de psicologia industrial e os teóricos da administração já há algum tempo perceberam um aspecto particularmente moderno do trabalho: o trabalho emocional. Ele tem estado presente há algum tempo, mas agora se torna claro que é um trabalho diferente do trabalho industrial. O trabalho emocional é todo aquele tipo de atividade no qual os sentimentos das pessoas representam as ferramentas utilizadas para seu trabalho. Ou seja, suas reações psicológicas, emocionais e pessoais são envolvidas como conseqüência de algum aspecto do próprio trabalho". O sentimento é de algum modo, uma parte do desempenho da tarefa e quase todas as funções envolvem alguma exigência humana em termos de trabalho emocional. Em algumas funções os psicólogos têm identificado uma reação especial nos seres humanos, denominada síndrome de sobrecarga de contato, que aflige as pessoas cuja função as põe em contato individual com muitas outras pessoas em base constante e repetida.

As funções de contato com clientes interno e externo contêm uma forte dose de trabalho emocional, por isso é difícil sua definição e é mais complexo ainda medir a competência para realizá-lo. Uma coisa é medir força física, habilidade manual, conhecimento técnico, ou a velocidade da digitação, outra coisa, bem diferente, é medir calor humano, preocupação com clientes, habilidades de relacionamento interpessoal, e flexibilidade emocional, porque o modelo industrial, muito diferente daquele exigido para a prestação de serviço, não se preocupou com esses fatores.

Para Albrecht (1992:228) "a montagem de uma equipe orientada para serviço é uma das metas de longo prazo do desenvolvimento de serviços. Embora os indivíduos em situação de trabalho sejam sensíveis ao ambiente que os cerca e à direção que recebem de seus supervisores, não é demais criar condições propícias ao sucesso, desde o início, obtendo pessoas que sejam adequadas para o trabalho de prestação de serviços". Isto quer dizer que as pessoas devem ser selecionadas cuidadosamente, e depois orientadas adequadamente antes de começarem a trabalhar. Sabe-se que a seleção de novos funcionários tem sido motiva de aprimoramento dos processos, mas mesmo assim a empresa não está vazia e muitos funcionários estão lá presentes, em atividade.

Para efeito das novas exigências requeridas quanto ao perfil profissional na organização, os administradores de recursos humanos não estão excluídos dessa avaliação do desempenho, principalmente porque há aqui um agravante - muitos perfis dos atuais 
administradores podem estar mais adequados para outras funções, que não as atuais. É variável a capacidade das pessoas em suportar o trabalho emocional. Muitos administradores ainda não perceberam completamente este fato. Na verdade, grande parte de nossa teoria da administração o ignora. Albrecht (2006) indica um ponto que pode contribuir muito para profissionais de Administração de Recursos Humanos e Gestores, que são por excelência profissões tidas como empáticas e com alta dose de trabalho emocional. O paradoxo é que por uma ironia das profissões empáticas, aquilo que um dia foi um idealismo pode se converter num calejado lastro, com o passar dos anos.

A ironia das profissões empáticas é que as pessoas erradas podem estar praticando-as. O autor enquadra em profissões empáticas as de psicólogos, psiquiatras e outros licenciados da saúde, mas há uma extensão aplicada aos Administradores de Recursos Humanos, Gestores de Pessoas, Professores, Médicos, Policiais, Clínicos da Saúde Mental, Funcionários de Serviço de Proteção aos Menores, Advogados, Funcionários de Atendimento e Recepção, dentre tantos outros, que ao prestarem assistência ao outro perdem a força emocional.

Conseqüentemente, para estes profissionais torna-se cada vez mais difícil enfrentar desafios ou simplesmente aquilo que lhes cumpre fazer. Albrecht (2006) traz algumas contribuições para que se perceba que um profissional atingido por essa desordem começa a evitar o contato com pessoas, apesar de sua ação requerer empatia, então quando eles desistem de seus ideais a tendência é que percam o vínculo com sua profissão, alterando a postura, desenvolvendo mecanismos de defesa e isolamento. Para alguns desses profissionais uma coisa é entender de comportamento, outra é operacionalizá-los, começando por si próprio.

Não se pode negar que a realidade está inundada por esse aspecto estressante de mudanças, incertezas, lideranças e gestores despreparados, falta de compreensão de uma nova realidade, pouca valorização da comunicação relacional e uma certa despreocupação com a importância de se adotar o princípio da convivencialidade para começar a tratar esses assuntos. Outros efeitos colaterais do trabalho emocional podem estar gerando reações e comportamentos, cada vez mais difíceis de se lidar no presente e no futuro, pois são transferidos à vida pessoal e retornam para a vida profissional, o que torna o trabalho, em muitos casos, insuportável e pouco compensador.

Em seus estudos sobre a corrosão do caráter, Sennett (2003) mostrou que a ênfase na empresa-privada e a visão de flexibilidade mudaram o significado do trabalho e também das 
palavras que empregamos para entender sobre ele. A carreira, durante muitos anos, foi sinônimo de canal para as atividades econômicas de alguém durante a vida inteira.

Esta necessidade de flexibilidade dos dias de hoje bloqueou a estrada reta da carreira e as pessoas passaram a ter que conviver com a liberdade para moldar suas vidas.

Uma nova ordem mundial impõe novos controles, em vez de abolir as regras do passado, mas também esses novos controles são difíceis de entender. Talvez o aspecto da flexibilidade que mais causa confusão seja seu impacto sobre o caráter pessoal.

Escritores da antiguidade não tinham dúvida sobre o significado de "caráter" como sendo o valor ético que se atribuí aos próprios desejos às relações com os outros. O clássico filósofo grego Horácio entendeu que o caráter de alguém depende de suas ligações com o mundo. Para Sennett (2003) o caráter é mais abrangente que a definição moderna de personalidade, pois se refere aos desejos e sentimentos que podem corroer por dentro, sem que ninguém veja. O termo caráter concentra-se no aspecto longo prazo da experiência emocional das pessoas e é expresso por lealdade e o compromisso mútuo, pela busca de metas em longo prazo, ou pela prática de adiar a satisfação em troca de um fim futuro. $\mathrm{O}$ caráter corrobora traços pessoais a que se dá valor a si próprio e pelos quais se busca que os outros valorizem. Como se decide sobre o que tem valor duradouro em cada um, em uma sociedade impaciente? Como buscar metas de longo prazo numa economia dedicada ao curto prazo? Como se pode manter lealdade e compromissos mútuos em instituições que vivem se desfazendo ou sendo continuamente re-projetadas? Estas são questões advindas da flexibilidade e há de se conviver com elas.

\subsection{3- Inteligência Social para Alcançar Resultados Humanos}

A convivência inteligente pode servir para facilitar as pessoas aprenderem a rearranjar os pensamentos sobre aquilo que cada um supunha estar arranjado, a levar a vida num espaço social inteligente. Conhecimento e métodos de produção aprendidos pelas pessoas

podem estar se tornando obsoletos mesmo antes que elas iniciem uma carreira ou apliquem os conhecimentos sobre os quais foram treinadas.

Esse é um tempo em que o valor do que se aprende está constantemente evaporando, os relacionamentos virtuais estão presentes, as pessoas trocando de carreira, sem vínculos, famílias mudando-se em busca de novas oportunidades e em condições transitórias. O modelo 
social está influenciado pela realidade local das diversas comunidades e a sensação de futilidade, alienação e falta do valor individual tendem a caracterizar essa época.

Nesse contexto a necessidade de um senso comunitário, longe de desaparecer requer de cada um uma competência social maior, Albrecht (2006) apresenta um conjunto de cinco competências primordiais para a vida: consciência situacional, presença, autenticidade, clareza e empatia. Estes conceitos mudam a visão da influência social e do funcionamento da sociedade humana. Para o autor o conceito de Inteligência Social-IS cristaliza muito sobre uma importante dimensão da eficiência humana e a caracterização de IS ocorre na combinação entre uma compreensão básica das pessoas - uma espécie de consciência social estratégica - e um conjunto de técnicas para bem interagir com elas. A Inteligência Social é a habilidade de se relacionar com as outras pessoas e conseguir que elas cooperem como você.

Para Albrecht (2006:26) a competência da "Consciência situacional é como uma espécie de "radar social" ou a habilidade de "ler" situações e interpretar os comportamentos das pessoas em tais momentos, em termos de suas possíveis intenções, estados emocionais e propensão a interagir" [...] a da "Presença" incorpora toda uma gama de padrões verbais e não verbais, como aparência, postura, qualidade de voz, movimentos sutis - uma coleção de indícios que as outras pessoas processam, numa impressão estratégica do indivíduo. A da “Autenticidade" são os radares sociais das outras pessoas, que captam os sinais dos comportamentos dos demais, o que as leva a julgar alguém como honestos, abertos, éticos, confiáveis e bem intencionados ou não autênticos. Da "Clareza" é a habilidade de explicar, esclarecer idéias e transmitir dados de forma clara, além de saber articular as visões e os cursos de ação propostas, o que permite a credibilidade e a conquista de cooperação alheia. Da "Empatia”, é algo que vai além de um sentimento por alguém, mas um sentimento compartilhado entre duas pessoas. A empatia é entendida como um estado de vinculação com outra pessoa e constrói as bases para interação e cooperação.

\section{Inteligência Social na Gestão COM Pessoas}

Compreender a questão da inteligência tem sido motivo de pesquisa, que extrapola as áreas de educação, filosofia ou psicologia e invade áreas técnicas do conhecimento. Algumas pesquisas acadêmicas sobre o funcionamento da mente prosseguem para descobrir medidas rigorosas das inteligências múltiplas que possam revelar o nível de inteligência das pessoas, 
ou seja, aquilo que vai além do raciocínio lógico e que afeta a forma de conduzir as questões da vida pessoal e profissional.

Há um forte interesse em caracterizar cientificamente essas inteligências e Albrecht (2006) entende que ampliar as pesquisas para caracterizar a Inteligência Social tem sido do interesse daqueles que trabalham no desenvolvimento profissional, comunicação e cultura organizacional, uma vez que todos eles continuam buscando modelos práticos que possam usar no dia a dia.

Sabe-se que o aspecto científico tem predominado na sociedade ocidental, mas não é possível excluir as verificações da ciência do senso comum, pois toda tentativa de definir e esclarecer sobre essas competências, mesmo que de forma subjetiva, pode servir para orientar a Gestão COM Pessoas, principalmente quanto ao desenvolvimento de capacidade individual para saber lidar com os aspectos inerentes ao ambiente da organização e das relações interpessoais. Então nesse sentido, o conceito de Inteligência Social pode contribuir para que a convivencialidade no mundo do trabalho, comece a ser compreendida e aplicada pelas pessoas que trabalham juntas, para que elas possam buscar um acordo referente à vida dos indivíduos na organização.

Esse estudo traz alguns elementos para chamar atenção sobre o sentido e as implicações da Inteligência Social como componente fundamental para orientar a Gestão COM Pessoas, pois a Inteligência Social pode acelerar o processo de reflexão sobre o papel da Administração de Recursos Humanos e seus profissionais assimilem a comunicação como uma competência de apoio para assumir a responsabilidade por resultados humanos.

É fundamental que os profissionais de Recursos Humanos sejam identificados pelos funcionários das empresas, como aqueles responsáveis por elevar a condição da comunicação e a inteligência, como competências essenciais para um saber agir com responsabilidade.

Gestão COM Pessoas é um modelo a ser adotado por Administração de Recursos Humanos e tende a ser considerada uma daquelas idéias que abalam com as estruturas convencionais e com as formas de pensar. Os próprios Administradores de Recursos Humanos podem se ver obrigados a descartar algumas crenças mais antigas e valorizadas por sua formação educacional e a experiência do dia a dia, crenças sobre eles e sobre os membros da organização, quanto ao que devem estar fazendo no novo contexto e como devem comunicar sobre isso. 
Para aprender sobre alcançar resultados humanos os gestores precisam aprender, a partir do exemplo dos Administradores de Recursos Humanos, sobre mudar idéias próprias e investir a favor do esclarecimento das causas que possam estar impedindo o alcance de resultados humanos nas organizações.

O modelo sugerido para gestão, comunicação e pessoas requer uma revisão de conceitos e ensinamentos envolvendo posturas ultrapassadas que ainda podem estar sendo praticadas: ignorar ou manter passividade frente às novas demandas do contexto de mudanças; não transmitir o espírito ou o significado das novas condições de trabalho; não tomar a iniciativa e não assumir liderança firme e coerente com os propósitos transformacionais; apegar-se às regras e regulamentos na tomada de decisão, em lugar de agir com bom senso e uma visão ampliada da realidade; estrangular a iniciativa dos colaboradores de modo geral ao refrear idéias novas e ainda não experimentadas, não valorizando o potencial desses profissionais; e, ignorar a necessidade de se tratar sobre essas novas idéias no ambiente de trabalho ao invés de procurar aprender novos conceitos de relacionamento e convivencialidade.

\subsection{4- Administração de Recursos Humanos e Inteligência Social}

É possível pensar na Administração de Recursos Humanos comunicando sobre inteligência social no âmbito das organizações e ainda pensar sobre os "porquês" ela não poderia não estar praticando a Inteligência Social. Entende-se que este é um tempo difícil e requer muito de sabedoria das pessoas, portanto vai além de contar com o nível da inteligência reconhecido pelos mais diversos instrumentos, pois trata da forma como ela é utilizada.

O conceito de sabedoria torna-se relevante para que se aprenda a olhar no entorno para compreender o que está ocorrendo e poder decidir - individual e coletivamente - quando é isso o que se quer que ocorra. Os conceitos de convivencialidade e inteligência social caminham lado a lado, porém talvez não se tornem amplamente aceitos se não forem comunicados nas organizações ou talvez porque possa parecer que não haja tempo para isso considerando o envolvimento das pessoas com seus afazeres. Vale a pena observar que esse tempo é relativo, pois sem que cada um percebesse a vida em sociedade introduziu o conceito de rapidez e ele foi absorvido como algo inerente ao estilo de vida contemporânea. Pensa-se que o mais rápido é o melhor ou ainda, por exemplo, quando um objeto se quebra, basta jogá- 
lo fora e comprar outro, rapidamente e com muitas facilidades. Esse pensamento está presente nas mentes das pessoas também quando elas estão nas empresas, pois por meio da Internet e Intranet é possível se comunicar rapidamente, curiosamente, muitas vezes descartando-se regras básicas de civilidade ou da própria língua.

Em função da velocidade a civilização está mudada, a sociedade está mudada, as instituições estão mudadas, as pessoas estão mudadas, o trabalho está mudado e o conhecimento como base dessa mudança chega mais rápido do que as pessoas conseguem fazer uso dele.

O desenvolvimento tecnológico está acelerado, mas o desenvolvimento humano não acompanha o mesmo compasso. Nas organizações os profissionais individualmente podem estar buscando esse desenvolvimento, mas trata-se de uma carga pesada, pois o ônus do interesse em desenvolver-se profissionalmente é de cada um e tem sido tratado como fato natural, que o indivíduo planeje a sua carreira talvez até com pouca clareza e facilidade. Resta refletir sobre esse fenômeno.

Nas organizações essa temática compete à Administração de Recursos Humanos, que nos dias de hoje é reconhecida pela função estratégica de buscar e reter talentos para suprir as necessidades da empresa. Resta refletir sobre mais esse fenômeno.

Para a Administração de Recursos Humanos obter resultados humanos, esta deverá reter e manter no contexto dos interesses de uma empresa, pessoas "equipadas" com algo parecido com consciência social, com a compreensão do que acontece a sua volta e com atitude para ocupar espaços organizacionais, que carecem de senso de conexão com a realidade local e global. A Administração de Recursos Humanos, com base nos estudos clássicos de comportamento organizacional tem enfatizado alguns modelos de ação, porém sempre no sentido de dar importância e comunicar valores, atitudes e norma de conduta, que são importantes para o indivíduo se moldar ao contexto organizacional. A administração de Recursos Humanos apoiada pela competência da comunicação pode ressaltar ações para o indivíduo se transformar no contexto organizacional. Se a primeira transformação já ocorreu no âmbito da área de recursos humanos então ela passa a ser reconhecida por seu discurso e prática: - Faça o que eu digo e faça o que eu faço!

Ao comunicar a postura desejada ela tende a ser "sentida" (gera um sentimento) em toda empresa e em todos os níveis, do topo da administração geral até o mais simples funcionário. Embora artigos, livros e teses retratem a evolução histórica da Administração de 
Recursos Humanos, não se encontram registros de estudos que chamem atenção sobre os paradigmas que orientam as ações de Recursos Humanos.

É uma ironia, mas a Administração de Recursos Humanos é tratada como uma "entidade suspensa" na estrutura organizacional, parece acima de tudo e de todos, servindo como instrumento para garantir operações compatíveis com as novas necessidades de competitividade organizacional.

Muito pouco se discute sobre a competência, a ética, a motivação e a forma de comunicar daqueles que fazem a Administração de Recursos Humanos e que devem ensinam os gestores.

Quando Alvim Toffler anunciou a Terceira Onda de Informação, já há quase quatro décadas, acreditava que uma inspiração tomaria conta do ambiente social e de trabalho. Foram muitos os gestores de pessoas que acessaram as suas obras, assistiram palestras, participaram de Workshops, foram aos Congressos para conhecer sobre o "futurista" que anunciava um novo mundo emergente, com pessoas e profissionais capazes de tomar atitudes transformadoras e baseadas em informações claras e de fácil acesso. Uma grande lição é que quem não aprendeu não pode ensinar, a sociedade e o mundo do trabalho podem estar agindo como se ainda continuassem aprisionados à Segunda Onda, que Toffler definiu como o modelo individual da produção.

É paradoxal, mas qualquer especialista da Administração de Recursos Humanos ou gestor de pessoas pode estar preparado para solucionar problemas com pessoas e as necessidades de produção e não necessariamente, para perceber o ruído fabril que ainda orienta a operação da área de Recursos Humanos. Os processos de trabalho envolvendo recrutamento e seleção, aplicação ao cargo, remuneração e benefícios, avaliação de desempenho e treinamento saíram sim diretamente da Era Industrial e muitas vezes demonstram que pouco se modificaram com o uso do conceito da Terceira Onda de Toffler.

O Modelo de Administração de Recursos Humanos pode mudar a nomenclatura para Gestão de Talentos ou Gestão de Pessoas, mas o modelo eficaz e econômico continua tendo como base a busca de resultados padronizados alinhados às estratégias organizacionais. Entende-se que esse paradigma de resultados padronizados pode estar contribuindo para uma mesmice no sentido de selecionar pessoas com potencial para desenvolvimento, para apresentar a empresa e promover a integração desses novos funcionários, promover ações para adaptação ao ambiente de trabalho e à estrutura vigente e definir políticas e 
procedimentos de recursos humanos, sem garantir a gestão com pessoas esteja ocorrendo de fato.

Para a Administração de Recursos Humanos pôr em prática "uma nova visão de resultados humanos", a área, representada por seus profissionais, deve se "inspirar" no sentido de aprender para ensinar aos gestores sobre novos conceitos, novas posturas e novas formas de trabalho para agregar valor econômico à empresa e valor social aos indivíduos.

Essa visão de RH como Resultados Humanos, confere à área de RH - Recursos Humanos uma nova função - ser responsável por apresentar respostas para uma efetiva capacidade de atrair, manter e reter talentos na organização, pessoas que possam fazer a diferença na organização e na sua própria vida. A Figura VI representa a junção do concreto com o abstrato e o ponto de encontro está no humano.

Figura VI- Recursos e Resultados Humanos

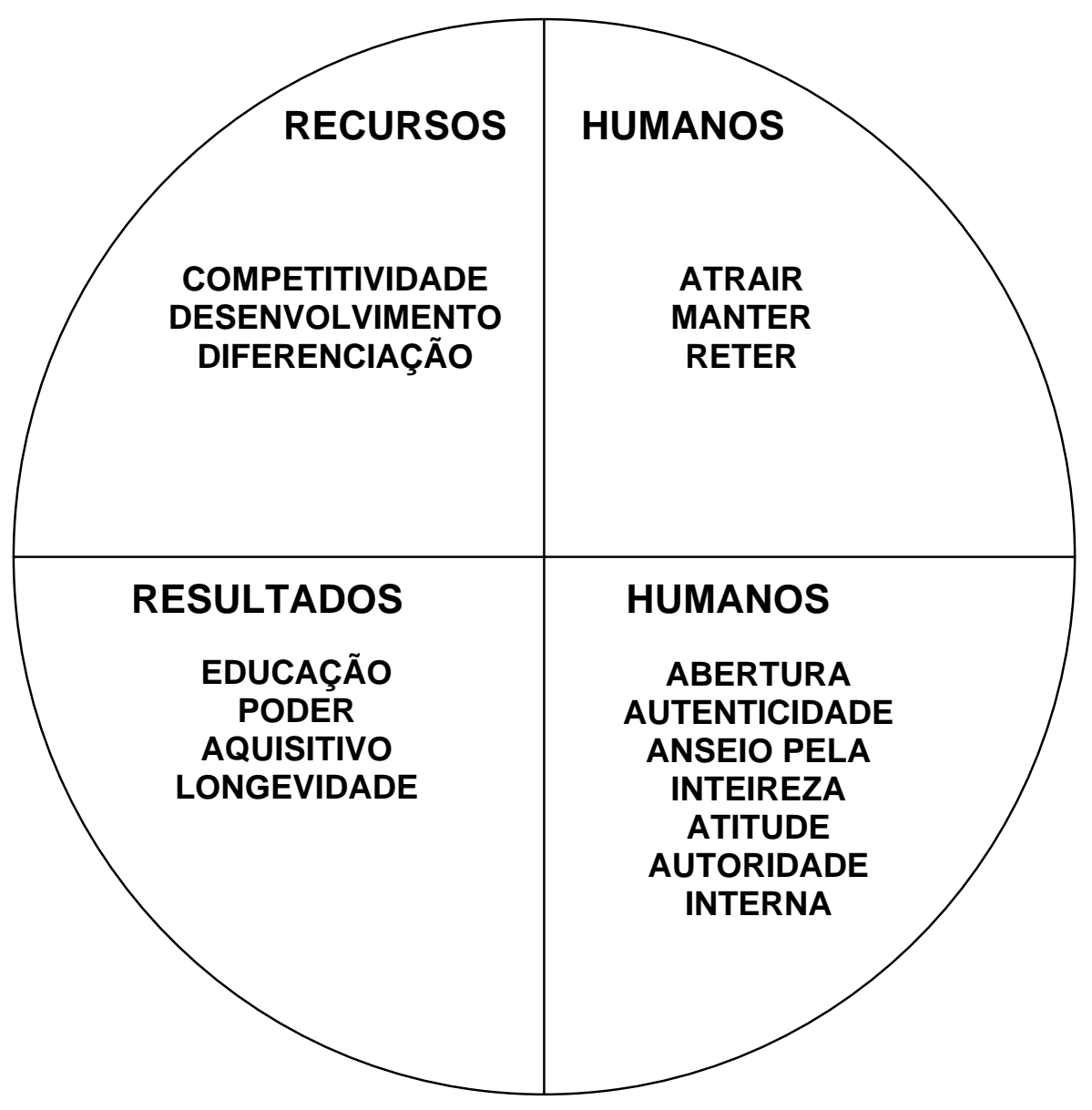


Uma visão funcional de Administração de Recursos Humanos aponta para um modelo de estrutura organizacional que se responsabiliza pelo Sistema de Administração de Recursos Humanos, cujas funções são Interação entre Pessoas e Organização, Subsistemas de Provisão, de Aplicação, de Manutenção, de Desenvolvimento e de Monitoração dos recursos humanos. Um inventário básico pode testar se as ações da Administração de Recursos Humanos e dos gestores de pessoas revelam o quanto o discurso sobre talentos está certo, mas o quanto essa prática pode estar errada.

A administração de Recursos Humanos pode com base na comunicação como competência de apoio se apresentar como a área responsável por elevar o nível de inteligência social da organização e conseqüentemente, das pessoas, na medida em que puder esclarecer sobre aprendizagem aplicada ao negócio e à conexão entre pessoas e a realidade, para que a busca por resultados financeiros não exclua a busca por resultados humanos.

Entende-se que essa é uma nova leitura da realidade: mais realista e compreensiva sobre o tempo presente, visão da necessidade de novas aprendizagens, criatividade para enfrentar essas dificuldades e desafios, investir no princípio da convivencialidade para que as pessoas tenham vontade de investir na sustentação da estrutura organizacional e na sua própria. Esse é um tempo de muitos desmoronamentos, a civilização experimenta o desenvolvimento tecnológico, mas o desenvolvimento humano não acompanha essa tendência. Assim, modelos, crenças e valores parecem "suspensos", pois não há um novo modelo a ser adotado. Esses desmoronamentos abalam as estruturas de vida em sociedade, dos indivíduos e do significado de produzir e de viver.

Nesse sentido, essa tese é resultado da busca de elementos da comunicação como competência que possa contribuir para um exercício de transformações internas às áreas de Recursos Humanos, para que profissionais de Administração de Recursos Humanos possam se ajudar e ajudar aos demais gestores, a se sentirem confortáveis em "pular fora" da Segunda Onda de Toffler.

Os profissionais de Administração de Recursos Humanos terão nota máxima na sua avaliação de desempenho quando trouxerem resultados para gestão dos recursos e dos humanos. Os gestores devem entender de acionistas e de humanos, os funcionários de linha de frente têm de entender de acionistas e de humanos - os clientes.

O melhor resultado humano pode ser estimulado pela Gestão COM Pessoas, cuja bandeira da inteligência social agita uma idéia simples - todos deveriam compreender a 
realidade, preparar-se para conviver com ela e criar diferentes ações, nos diversos sentidos do fluxo da comunicação no âmbito profissional e pessoal. Administrar recursos humanos, gerenciar talentos ou fazer gestão de pessoas dificilmente trará resultados melhores do que Gestão COM Pessoas, quando o paradigma de comunicar algo para as pessoas é substituído pelo paradigma de se comunicar com as pessoas. Nesse sentido a Gestão COM Pessoas requer mais alguns esforços de comunicação dos gestores:

- Melhorar a habilidade de comunicação, como competência de apoio para a sua própria ação;

- Conhecer sobre convivencialidade para poder estimular ações e programas de convivencialidade e

- Aprender para poder ensinar às pessoas sobre o desenvolvimento da competência de comunicação, que tem como base a compreensão do momento presente, o senso de conexão de cada um com a realidade local e global e, a necessidade de novas aprendizagens .

Em 20 anos o retrato da sociedade, da empresa e da Administração de Recursos Humanos terá o aspecto delineado pelas ações desenvolvidas hoje. A conjuntura conspira para a necessidade de se criar uma alternativa, socialmente mais inteligente, para a vida humana. $\mathrm{O}$ presente é agora e o momento é este. Nas organizações a Administração de Recursos Humanos pode deixar de ser a área que decide o destino das pessoas: fazer a seleção, o treinamento, a avaliação, o treinamento, a promoção e a demissão, para ser o apoio às

\section{transformações no tratamento dado às pessoas.}

A valorização da comunicação com modelo de Gestão COM Pessoas pode ser um marco evolutivo para a área de RH, pois o processo se inicia com a capacitação dos gestores para propósitos mais amplos, no sentido de apoiar o desenvolvimento de pessoas e de garantir o engajamento em projetos cujos objetivos sejam projetados para o alcance de resultados financeiros e resultados humanos, resultados que vão além de alto desempenho, preconizados pelas escolas de gerenciamento, mas levam a uma visão ampliada de interesses e perspectivas de ação, que se curvam diante da perspectiva histórica econômica de todo um planeta em renovação. 


\section{CONSIDERAÇÕES FINAIS}

A herança gerencial deixou marcas que afetaram sensivelmente os modelos de gestão no mundo contemporâneo, dificultando a ocorrência de mudanças obrigatórias na administração de recursos humanos, que possam favorecer as novas demandas de desenvolvimento de competências.

Desaprender os conceitos tradicionais de gestão é uma alternativa para oferecer um ambiente inteligente aos funcionários, o qual lhes possibilite o aprendizado e ao mesmo tempo, eleve os padrões competitivos de uma empresa com base no desenvolvimento de competências.

Desde Taylor e Fayol, os conceitos de administração evoluíram de forma que em cada época, surgiu uma configuração de um modelo a ser seguido, ocorrendo paralelamente tentativas de se livrar dos componentes do padrão anterior. Parece que um modelo ultrapassado deve ser rapidamente abandonado em favor da consolidação do novo padrão ou teoria emergente. Como exemplo dessa visão de modelo de management, a Experiência de Hawthorne foi considerada como algo mais ideal do que realista e novos enfoques possibilitaram o surgimento de outras escolas administrativas preocupadas com a modelagem do comportamento, motivação, trabalho em equipe e o papel da liderança. Observam-se algumas contribuições que deveriam ter mudado os rumos do tratamento dados às pessoas na organização e que permaneceram como um desafio à área de gerenciamento:

d) Necessidade da administração de recursos humanos das empresas, bem como seus gestores, saber identificar claramente o que interessa e o que preocupa os trabalhadores;

e) Resolver problemas com questões organizacionais de uma forma sustentável, quando é feito com esquemas adequados e com a efetiva contribuição das pessoas;

f) O processo de avaliação dos profissionais não é algo estático, mas deve ocorrer ao longo das situações enfrentadas no trabalho. O que requer acompanhamento e preparo para dar autonomia de ação ao grupo.

Em função desta sucessão de modelos, alguns insatisfatórios, foram criados espaços ao longo da história da administração para o surgimento de um conceito "mágico" - os paradigmas da administração - repetidos até o seu esgotamento, mesmo que em essência sejam desconhecidos ou até incompreensíveis. Para alguns a adoção do jargão: “é preciso 
superar os paradigmas!" ou "vamos criar novos paradigmas!" parece ser o suficiente para solucionar os problemas da empresa, mas isso não basta.

Um melhor entendimento sobre o significado de paradigma, mostra que, apesar de ser cada vez mais utilizado para indicar barreiras e/ou limites a serem superados no contexto apresentado, paradigma quer dizer "elaborar um modelo", ou seja, criar formas de medir aquilo que queremos avaliar, de modo que seja possível conhecer e julgar o que se quer avaliar. Trata-se, portanto de um modelo de avaliação em menor escala, não se refere a um modelo do desconhecido, mas apenas uma reapresentação. Assim, não há nada para impor que um paradigma emergente tenha de necessariamente, substituir o anterior, apesar de trazer sua contribuição com uma concepção, percepção e visão aprimoradas.

Para efeito desta tese, no universo da administração, neste momento, o primeiro paradigma é definir que tipo de sujeito é alvo da área de Recursos Humanos: embora todas as empresas reconheçam que é formado por pessoas, o mais importante é saber se são consideradas e tratadas como "pessoas úteis" ou "pessoas em desenvolvimento". As competências relacionam-se ao "saber fazer algo", que envolve uma série de habilidades. As habilidades expressam aptidões do indivíduo e a disposição, ou vontade, para fazer algo.

Quando uma pessoa se sente valorizada e dignificada pela empresa em que trabalha é capaz de "entregar" seus conhecimentos e se comprometer com a sua ocupação, de forma independente e autônoma, o que é sinal de estar alinhada às novas necessidades da organização.

A ação da área de recursos humanos, voltada ao desenvolvimento de competências, precisa integrar aspectos técnicos e humanistas e, para melhor valorização dessa integração, considera que aspectos de dimensão do ser, de percepção de ação, de ciclo vital, de concepção e de visão, devem ser revistos.

Fazendo um paralelo na forma como uma pessoa possa estar sendo tratada por gestores, como "útil" ou "desenvolvida" e nas conseqüências desse ato, verifica-se que na dimensão do ser, uma é vista como alguém que participa e a outra, compromete-se; na percepção do ser uma é dependente e a outra, independente; na ação do ser uma é subordinada e a outra, autônoma; no ciclo vital para uma há menor perspectiva de longevidade e para a outra, maior; na concepção do ser uma é um objeto descartável e para a outra é pessoa; e na visão do ser uma é homo economicus e a outra é parceira. Observa-se um confronto analítico, no qual as pessoas podem ser iguais na semântica, mas profundamente discordantes na essência do ser humano, no seu desenvolvimento e na sua dignidade. 
As organizações e seus gestores precisam aprender a lidar com esses extremos e viabilizar a junção dos aspectos tecnicistas com os humanos. São os profissionais de RH, que mais do que se adaptarem ou se deformarem, agindo como sinalizadores de mais um novo amoldamento, devem desenvolver a sua própria transformação para ensinar aos demais sobre essa integração de aspectos técnicos e humanistas.

Conforme manuais e teorias vigentes, as políticas de Administração de Recursos Humanos revelam por meio de suas estruturas, que com base nas diretrizes e políticas, abrigam atividades departamentalizadas no tratamento dado às questões relacionadas com o funcionário: remuneração, benefícios, treinamento e avaliação de desempenho. O indivíduo recebe tratamento isolado dentro do contexto e de modo geral sua relação com a administração de recursos humanos está na dependência do reconhecimento de seu valor e da perspectiva de aproveitamento de seu potencial para melhores oportunidades ocupacionais ou condições salariais.

É comum nas empresas a necessidade - poucas vezes satisfeitas - de que os funcionários estejam em comunicação e em sintonia com os objetivos organizacionais. O que pode tornar-se grave nessa situação é que muitas vezes dirigentes e gestores não representam o "espelho" do perfil que a empresa requer para que haja essa sintonia, isso ocorre quando:

- Algumas organizações desconhecem o rumo que desejam seguir;

- A maioria das pessoas não está consciente de que ao ser contratado como membro de uma organização, fazem parte de um objetivo organizacional que as transcende e as compromete;

- Descrições de cargo, quando existem, não definem sobre uma função crucial que é saber comunicar-se. Não há trabalho sem comunicação, mas a administração de Recursos Humanos procura garantir que nas descrições de cargos hajam verbos como reportar, verificar, supervisionar, documentar, mas não há nada para que se defina a comunicação como uma competência requerida, utilizando-se verbos como dar feedback, comunicar, integrar, co-responsabilizar-se, reproduzir idéias ou ser reproduzido nas suas idéias;

- O trabalho se torna rotineiro e pouco satisfatório, pois é executado sob comando e instruções. Observa-se que mesmo em um pólo oposto pode haver muito dinamismo, mas nem sempre isso garante que as trocas alcancem toda a organização. Como se tratam de extremos os resultados em ambos os casos é o mesmo, há um enfraquecimento da identificação dos colaboradores com a visão da empresa; 
- Empresas se sustentam nos pilares de uma corporação, não conciliam os planos locais e globais e passam a correr o risco de atuar mais por obrigação contratual do que por estratégia. Novamente a conseqüência será uma comunicação escassa entre a organização e as pessoas que a compõem.

- Empresas não formalizadas dependem da vocação de comunicação do gerente ou gestor, então a comunicação dependerá de seu estilo de administrar.

A comunicação pode transformar as práticas de Administração de Recursos Humanos, enquanto competência de apoio, para encurtar distâncias rumo ao desenvolvimento de competências e também de resultados humanos. São poucas ou talvez quase nenhumas as fontes, como livros, artigos, pesquisas, que estimulem uma reflexão e uma avaliação sobre gestão se comunicando com pessoas, mas essa omissão pode representar uma ameaça à realização do maior desafio declarado da área de recursos humanos -: atrair, manter e reter talentos nas organizações.

Para gerar uma cultura de gestão comunicação e pessoas - Gestão COM Pessoas o primeiro passo está em valorizar a comunicação como uma linguagem a ser adotada para encarar novas idéias. Há um reconhecimento de que a comunicação não é uma função da área de comunicação, de RH, da direção ou de uma prestadora de serviços, é responsabilidade da organização e nesse sentido é de responsabilidade de todos os membros da organização. A idéia é que pouco a pouco se transforme em algo menos controlável ou controlador e mais uma ação consciente, cientificamente falando.

A cultura de gestão e comunicação deve ser expressa em discurso e prática, isto é, as ações de RH e dos gestores que possam ser observadas por todos.

Para que a comunicação se converta em cultura ela passa a ser compreendida como uma competência que pode ser desenvolvida e integrada ao cotidiano das empresas favorecendo resultados, melhorias em sistemas e principalmente, facilitando a convivencialidade entre os membros de uma organização. Então o que há para aprender na nova cultura é sobre compartilhamento de valores, objetivos institucionais, objetivos individuais, princípios de ação e clareza quanto aos princípios e regras que devam orientar a convivencialidade. Trata-se de um exercício sobre "busca de acordo" entre as pessoas e prática da empatia, da assertividade e da negociação.

Alguns aspectos ao serem avaliados podem revelar como ocorre a relação da comunicação na organização e há de se considerar comunicação em dois sentidos, um geral que diz respeito aos métodos clássicos e o outro o humano. Para que novas circunstâncias gerem espaço para melhor compreensão de comunicação apoiando a gestão e 
convivencialidade é preciso que haja uma transcendência da cultura organizacional em benefício das empresas e das pessoas.

O sentido humano visa conseguir que entre as pessoas haja um ponto comum - um acordo. O significado de comunicação considerado nesse trabalho refere-se à complexidade de um intercâmbio de palavras e idéias que se dá entre os indivíduos, e que a comunicação autêntica entre as pessoas somente possa ocorrer por uma condição de afinidade com a outra pessoa, implica colocar-se no lugar do outro para perceber o que há de comum entre os envolvidos naquele ato. Logo não é algo que possa acontecer se não houver a vontade do indivíduo.

A comunicação, para os profissionais, não pode continuar sendo uma espécie de “caixa-preta". É sabido que a expressão "caixa-preta" tem significado metafórico, que pode designar qualquer coisa misteriosa nas mais diversas áreas. Na gestão, a comunicação pode não estar sendo utilizada para rever a própria ação como profissional, para que gestor e suas equipes aprendam sobre definir melhor posicionamento diante das necessidades de transformações ou de fazer a diferença no resultado como um todo (organização, pessoas, comunidade).

Quando ela é ineficaz não há receita simples para instaurá-la e depende dos níveis de pressão e stress, tipo de ação mais comum e energia.

Novas práticas para que ela seja sempre eficaz dependem de novas aprendizagens que permitam fazer frente às dificuldades intelectuais, emocionais e à exposição decorrente de alguém se ver ameaçado de perder seu sustento ou entrar em contato com a defasagem entre seus objetivos, seus conhecimentos e a realidade emergente.

A comunicação como uma competência de apoio favorecerá a mudança dos padrões de gestão, pois o sentido está em aprender lidar com idéias que possam transformar os caminhos para se alcançar resultados humanos em paralelo com os econômicos. Sabe-se que há muita preocupação com a comunicação na organização, principalmente para esclarecer sobre necessidades de acionistas e clientes e o posicionamento dos profissionais.

As empresas contam com uma multiplicidade de meios para uma abertura de canal de comunicação entre os membros da organização. Nesse sentido utilizam-se palestras, informações no Website e na Intranet da empresa, marcam-se reuniões e discutem-se sobre treinamentos e seminários.

Há uma visível tentativa de recuperar a comunicação espontânea porque na prática espera-se conseguir o "envolvimento dos empregados", mas pouco se questiona sobre as causas que podem estar impedindo uma maior integração de fato. Nesse sentido, a 
vigilância continua porque muitos não saberão lidar com a comunicação autêntica, mesmo porque ela transita em seus vários gradientes. Em um extremo ela pode ser uma contribuição para compreensão e para tomada de decisão, mas por outro faz emergir mais incertezas, que trazem no seu bojo a insegurança, o questionamento do sentido e dos rumos da própria existência.

Para alinhar desenvolvimento organizacional e individual, a administração de recursos humanos deve oficializar um modelo de gestão COM pessoas, apoiado por programas e ferramentas que promovam a interação das pessoas com base nos princípios compartilhados de convivencialidade, nos ajustes de procedimentos, políticas, processos de trabalho, agora em função das novas competências desenvolvidas. Por último é preciso definir parâmetros de conduta e indicadores que permitam avaliar o desenvolvimento alcançado a partir da compreensão da comunicação como competência de apoio à ação dos profissionais.

A avaliação permite que os resultados alcançados sirvam de feedback para estimular o desenvolvimento do potencial humano e a comunicação é entendida como sinônimo de chegar a acordos, compreender a realidade, encontrar objetivos comuns e criar uma identidade em torno da perspectiva de aprendizagem. Não se trata de querer que pessoas sejam todas iguais e muito menos que pessoas e organizações se tornem unas, trata-se sim, de reconhecer idéias simples, como a de que para haver desenvolvimento há necessidade de se reconhecer que não será da mesma forma que se convive hoje.

O fato é que o ambiente de empresa é feito para parecer muito mais "complicado e perigoso" do que é na realidade. O ambiente organizacional leva muitos profissionais a produzirem ambientes embaraçosos e pouco inteligentes. Talvez em alguns cargos ou postos de trabalho essa condição de dificuldade, ameaça, contradição, até estejam presentes para manter ou justificar sua existência. Para as demais pessoas envolvidas, que vivem nesse ambiente considerado esmagador, os seus métodos adotados para lidar com o ambiente devem ser inadequados para a sua própria sobrevivência. Então, por que é que as pessoas fazem um esforço para fazer com que o ambiente pareça mais “esmagador” do que já é? Exemplo óbvio pode ser visto em jornais, pois não existem artigos que descrevam boas notícias e muito provavelmente isso representaria o fim dos interesses desse segmento.

Almejar um ambiente de convivencialidade e de boas notícias se tornou algo imprudente ou inadequado num ambiente global que promove a incerteza e o medo. Talvez a idéia que esteja por trás disso tudo seja manter o "outro" preocupado e aflito para que cada um faça exatamente o que está sendo pedido a ele. 
A verdade, porém, é que o ambiente pode não ser de tanto transtorno como se faz parecer, pois uma quantidade enorme de pessoas e vasta quantidade de dinheiro estão produzindo esse ambiente "perigoso".

Acredita-se que essa ameaça potencialmente hostil possa ser reduzida com a aprendizagem e com a perspectiva das pessoas saberem mais sobre elas próprias, do "outro" e da realidade ao seu redor, para que cada um consiga uma melhor compreensão das situações e tenha menos dificuldade no seu meio. Um indivíduo menos ameaçado pelo meio ambiente tende a ressurgir, torna-se menos apático e pensa sobre o que pode fazer acerca do seu profissional e da vida pessoal.

A introdução de discussões sobre conceito e princípios de convivencialidade deve orientar as ações dos gestores para que eles sejam co-responsáveis por tornar o ambiente menos "esmagador" e aumentar a capacidade das pessoas em resolver problemas existentes, em vez de criar problemas.

Pode parecer inocente essa visão de uma sociedade diferente, de uma empresa diferente, mas muito provavelmente aqueles que não gostam de influências que acalmam, se revelarão como pessoas preocupadas em lutar contra qualquer coisa que diminua a perturbação do ambiente. O controlador entrará em luta para perturbar o ambiente, mas acredita-se que sua personalidade é uma fraude.

A convivência na vida organizacional e o bloqueio à comunicação autêntica encobrem cada um com uma "máscara" de profissional e suas competências. A verdadeira face não se expõe, mesmo porque há uma ameaça inerente a quem se expõe, pois quem erra ou falha pode desagradar e até mesmo gerar uma demissão. Há pouca discussão sobre algumas questões inerentes às mudanças e o desenvolvimento de competências: o contexto organizacional é que gera o dinheiro para sobrevivência, a perspectiva de manter o trabalho e o status adquirido.

Então é verdade que a organização em um extremo garante a satisfação e no outro, a sansão. A inteligência das pessoas é utilizada para que a empresa possa atingir resultados, competência e aprendizagem são alcançadas com troca de conhecimento e compartilhamento de informações, exige-se clareza na visão das pessoas sobre a necessidade de desenvolvimento, é necessário preparo dos gestores para lidar com essas novas tendências, e não há como negar a contribuição da comunicação para a gestão de pessoas inteligentes.

O modelo em construção, de Gestão COM Pessoas, pode ser mais bem elaborado por administradores de RH e gestores quando se aprender a "desaprender" as respostas 
previamente estabelecidas por modelos ultrapassados e que não são mais capazes de responder às demandas da nova realidade organizacional. É necessário “desaprender”, para reaprender a lidar com as causas que estão impedindo as empresas e gestores de valorizar o potencial das pessoas e os resultados humanos.

Todas as empresas, sem exceção, têm três grandes desafios pela frente: manter estruturas menores, aperfeiçoar processos administrativos, produtivos e de prestação de serviços e oferecer aos clientes produtos e serviços com valor agregado, aos diferentes perfis sócios econômicos do mercado. Para tal é preciso aplicar a aprendizagem contínua na gestão, em métodos de trabalho, nos processos, nos produtos, nas pessoas e ambientes. Esse aprimoramento implica desenvolvimento de competências organizacionais e individuais, o caminho que pode conduzir ao desenvolvimento a partir da "entrega" de conhecimentos e de responsabilidade de ação.

$\mathrm{Na}$ medida em que a eficácia da ação dos gestores dependerá cada vez mais das competências individuais e coletivas de todos profissionais da organização e, antes de tudo, da competitividade como um todo, haverá cada vez mais a necessidade de desenvolver respostas diferenciadas frente à diversidade e à complexidade do contexto de trabalho.

A competitividade da organização supõe que todos seus atores sintam-se responsáveis não apenas pelos resultados organizacionais, mas também por seu próprio desenvolvimento profissional, o qual está estreitamente vinculado à concepção e à implementação de um modelo de gestão de pessoas. Explicitando e confrontando seus pontos de vista, explorando coletivamente novas vias de gestão, avaliando de forma contínua a progressão dos profissionais, sem exceção, e verificando a pertinência e a coerência das abordagens escolhidas, os diversos atores são levados a mobilizar e a desenvolver permanentemente novos saberes, entre os quais saberes referentes à gestão e à comunicação.

Uma empresa difere da outra e essa diferença resulta da maneira como cada organização vem construindo uma cultura organizacional local fundada em múltiplos ajustes, que são mais ou menos explícitos e negociáveis, visando tornar compatíveis e justificar lógicas contraditórias ao tratamento das pessoas dentro da organização: garantir a igualdade de tratamento, lutar contra o fracasso profissional e a favor do desenvolvimento, transmitir valores sociais adequados à evolução sociocultural e econômica, manter a qualidade de vida, exigir mais de si próprio, levar em conta as necessidades das pessoas, respeitar a individualidade no quadro dos projetos organizacionais.

Diante dessas lógicas contraditórias, as organizações não dispõem de gestores preparados para as novas necessidades, alguns gestores se limitam aos conhecimentos 
técnicos na sua prática de gestão e se contentam em empregar os instrumentos mais correntes de avaliação de desempenho; eles marginalizam muitos funcionários. Se, ao contrário, leva em conta a diversidade no grupo e apóia as pessoas que apresentam mais dificuldade para desenvolvimento de competências, pode então dar prioridade de acesso a novas ocupações e às novas responsabilidades, àqueles que caminham para o desenvolvimento com excelência.

A solução para os gestores consiste em se inserir exclusivamente em uma dessas lógicas, o que é estimulado por uma minoria de empresas. Faltam algumas competências profissionais e princípios de convivencialidade como participação, cooperação, prática de contrato e de avaliação, a transparência na informação, a negociação e o acordo, que estão defasados em relação à cultura de gestão, ainda fortemente enraizada no individualismo e na visão hierárquica dos procedimentos de gestão e de controle.

Para responder ao paradigma de pessoas em desenvolvimento e valorizados por seus conhecimentos, a área de Recursos Humanos deve "refazer" seu próprio modelo de atuação, tomando por base, conceitos e modelos aqui apresentados e que podem ser testados no sentido de combater possíveis causas que impeçam o desenvolvimento das pessoas na organização. A idéia de uma revisão do próprio modelo de gestão requer a capacidade de "desvestir" os modelos impostos, pois só assim os profissionais de RH serão capazes de ver, aprender e colocar em prática, com convicção, conceitos que permitam alcançar mais do que resultados econômicos, estarão convictos, a partir do próprio exercício, a promover resultados humanos mensuráveis a partir de indicadores que permitam uma avaliação do perfil do profissional estimulado ao desenvolvimento, pois ele deverá manifestar nas suas ações a abertura de sua mente, a autenticidade, o anseio pela inteireza (pensar, sentir e agir), atitude e autoridade interna.

Exige-se um posicionamento dos administradores e gestores. Esse tem sido um problema para as empresas que investem em técnicas para desenvolvimento e capacitação de pessoal, em marketing de relacionamento ou em outros, sem que as idéias sobre relacionamento ganhem espaço para serem lançadas à discussão dentro da própria empresa, entre os profissionais, e aplicados para o bem de todos. Ao invés disso o que se encontra é muita acomodação em padrões, que não apresentam mais sentido, portanto essas posturas têm sido alvo de críticas e consideradas indesejadas, de modo geral. Então fica a questão de como tem sido comunicado aos gestores esse tipo de dificuldade, pois são eles que estão mais diretamente envolvidos com as pessoas e como a administração de recursos humanos tem verificado as causas que têm impedido essa mudança de padrão e "atacado" nesse campo. 
Acredita-se que é necessário refletir sobre a aprendizagem não apenas como sessões de treinamento, mas como resultado do convívio entre as pessoas, como ampliação da visão de necessidades do "outro" e como melhor compreensão do conceito de autodesenvolvimento a caminho do desenvolvimento profissional. Não se trata de amenizarem impactos ou dificuldades porque podemos estar adiando causas cujo efeito se traduz por cegueira e ignorância cada vez mais crônicas. 


\section{BIBLIOGRAFIA}

ABRAHAMSON, Eric. Mudança Organizacional. São Paulo: M. Books do Brasil, 2006.

AGOSTINHO, Márcia Esteves; BAUER, Rubem; PREDEBON, José (ORG.) Convivencialidade: A Expressão da Vida nas Empresas. São Paulo: Atlas, 2002.

AGOSTINHO, Márcia Esteves. Cap.1: Aprendizado Coletivo Como Resposta a Crises in Convivencialidade: A Expressão da Vida nas Empresas / Márcia Esteves Agostinho, Rubem Bauer, José Predebon (organizadores). São Paulo: Atlas, 2002.

ALBRECHT, Karl. Revolução nos Serviços: como as empresas podem revolucionar a maneira de tratar seus clientes; tradução de Antonio Zoratto Sanvicenti. São Paulo: Pioneira, 1992.

do Brasil, 2006.

Inteligência Social: a Nova Ciência do Sucesso. São Paulo: M. Books

ALBUQUERQUE, Luiz Guilherme. O Papel Estratégico de Recursos Humanos. Tese de Livre Docência apresentada à Faculdade de Economia, Administração e Ciências Contáveis da Universidade de São Paulo em 1987.

Competitividade e Recursos Humanos - Trabalho apresentado no concurso de Professor Titular, São Paulo, FEA/USP, 1992.

ALMEIDA, Martinho Ismar Ribeiro; MARTINELLI, Dante. Pinheiro; TEIXEIRA, Maria Luiza Mendes. Por quê administrar estrategicamente Recursos Humanos?. Revista de Administração de Empresas (FGV), v. 33, p. 12-24, 1993.

ANTUNES, Ricardo. Os Sentidos do Trabalho: Ensaio Sobre a Afirmação e a Negação do Trabalho: São Paulo: Boitempo Editorial, 2003.

APOLINÁRIO, Fabio. Metodologia da Ciência: filosofia e prática da pesquisa. São Paulo: Pioneira Thomson Learning, 2006.

AQUINO, Cleber Pinheiro. Administração de Recursos Humanos. São Paulo: Atlas, 1984.

ARENDT, Hanna. A condição Humana. Rio de Janeiro: Best Seller, 1989.

ARGYRIS, Chris. Personalidade e Organização : O conflito entre o sistema e o indivíduo. Rio de Janeiro: Renes, 1957.

BACCEGA, Maria Aparecida (Org.). Gestão de Processos Comunicacionais .São Paulo: Atlas, 2002.

BALDISSERA, Rudimar. Comunicação Organizacional: O treinamento de recursos humanos com rito de passagem. São Leopoldo: UNISINOS, 2000.

BENDASSOLLI, Pedro Fernando. O vocabulário da habilidade e da competência: algumas considerações neopragmáticas. Cadernos de Psicologia Social do Trabalho, São Paulo - USP, v. 3/4, p. 65-76, 2001.

BERLO, David K. O Processo da Comunicação: introdução à teoria e à pratica. São Paulo: Martins Fontes, 2003.

BOOG, Gustavo G. O desafio da Competência. Rio de Janeiro: Best Seller, 1995.

Makrom Books, 2006.

Manual de Treinamento e desenvolvimento ABTD. São Paulo; Pearson 
BOHM, David. A Totalidade e a Ordem Implicada: Uma Nova Percepção da Realidade. São Paulo: Cultrix, 1998.

BOHM, David. On Dialogue. Londres: Routledge, 1998.

BOHLANDER, George; SNELL Scott; SHERMAN Arthur. Administração de Recursos Humanos. São Paulo: Pioneira Thomson Learning, 2003.

BOWDITCH, James L. e BUONO, Anthony F. Fundamentos do Comportamento Organizacional/ Tradução Luiz Henrique Baptista Machado. Rio de Janeiro: LTC, 2006.

BUENO, Wilson da Costa. Comunicação Empresarial: Teoria e Pesquisa. Barueri- SP: Manole, 2003.

CATTANI, Antonio David ; HOLZMANN, Leon. Dicionário de Trabalho e Tecnologia. Porto Alegre: Editora da UFRGS, 2006.

CERVO, Amado Luis; BERVIAN, Pedro Alcino. Metodologia Científica. São Paulo: Prentice Hall, 2002.

CARVALHO, Antonio Vieira de. Aprendizagem Organizacional em Tempos de Mudança. São Paulo: Pioneira, 1999.

CERTO, Samuel C. Administração Moderna. São Paulo: Pearson, 2002.

CHANLAT, Jean François (coordenador). O Indivíduo na Organização: Dimensões Esquecidas - Vol I, II e III. São Paulo: Atlas, 1996.

São Paulo: Atlas, 2000.

, Ciências Sociais e Management: Reconciliando o Econômico e o Social.

CHIZZOTTI, Antonio. Pesquisa em Ciências Humanas e Sociais. São Paulo: Cortez, 1991.

COHN, Gabriel (et al). Desafios da Comunicação. Petrópolis Rio de Janeiro: Vozes, 2000.

CORRADO, Frank .M. A Força da Comunicação. São Paulo: Makron Books, 1994.

CORRÊA, Henrique L. Teoria Geral de Administração: Uma abordagem Histórica da Gestão de Produção. São Paulo: Atlas, 2003.

DAFT, Richard L. Administração; [tradução Robert Brian Taylor]. São Paulo: Pioneira Thomson Learning, 2005.

DAVIS, Keith e NEWSTROM, John.W. Comportamento Humano no Trabalho: Uma Abordagem Psicológica- vol. 1. São Paulo: Pioneira Thomson Learning, 2002.

, Comportamento Humano no Trabalho: Uma abordagem

Organizacional- vol. 2. São Paulo: Pioneira Thomson Learning, 2001.

DAVEL, Eduardo ; VASCONCELOS, João (Org.). Recursos Humanos e Subjetividade. Petrópolis, RJ: Vozes, 2000.

DAVEL, Eduardo ; VERGARA, Sylvia Constant (Org.). Gestão com Pessoas e Subjetividade. Petrópolis: Vozes, 2001.

DELORS, Jacques (Org.). Educação: Um Tesouro a Descobrir/ Relatório para UNESCO da Comissão Internacional sobre Educação para o Século XXI. São Paulo: Cortez; Brasília, DF: MEC: UNESCO,1999.

DEJOURS, Christophe. A Loucura do Trabalho: Estudo de Psicopatologia do Trabalho. São Paulo: Cortez, 1992. 
DEETZ, Stanley. Chapter 1: Conceptual Foundations in The Handbook of Organizational Communication: Advances in Theory, Research, and Methods / edited by Frederic M. Jablin and Linda L. Putnam. Thousand Oaks, California: Sage Publications, 2000.

DE MASI, Domenico. O Ócio Criativo. Rio de Janeiro: Sextante 2000. , Desenvolvimento Sem Trabalho. São Paulo: Esfera, 1999.

DEMO, Pedro. Metodologia do conhecimento Científico. São Paulo: Atlas, 2000. , Pesquisa: princípio científico e educativo. São Paulo: Cortez, 2003.

, Introdução à Sociologia: Complexidade, Interdisciplinaridade e Desigualdade Social. São Paulo: Atlas, 2002.

DERTOUZOS, Michel. O que será: Como o Novo Mundo da Transformação Transformará Nossas Vidas. São Paulo: Companhia das Letras, 2000.

DESSLER, Gary. Administração de Recursos Humanos. São Paulo: Prentice Hall, 2003. Petrópolis: Vozes, 1998.

Conhecimento Moderno: Sobre a ética e intervenção do conhecimento.

DOWBOR, Ladislau [et. al.]. Desafios da Comunicação. Petrópolis Rio de Janeiro: Vozes, 2000.

DRUCKER, Peter F. The Practise of Management. New York: Harper \& How, 1954.

Prática da Administração de Empresas. São Paulo: Pioneira de Administração e Negócios, 1981.

Sociedade Pós- Capitalista. São Paulo: Pioneira, 1993.

DURKHEIM, Émile. As Regras do Método Sociológico. São Paulo: Companhia Editora Nacional, 1972.

O suicídio: estudo de sociologia. São Paulo: Martins Fontes, 2004.

DUTRA, Joel Souza (Org.). Gestão por Competências. São Paulo: Gente, 2001.

Paulo: Atlas, 2002.

Gestão de Pessoas : modelos, processos, tendências e perspectivas. São

Competências: Conceitos e Instrumentos para a Gestão de Pessoas na Empresa Moderna. São Paulo: Atlas, 2004.

EDVINSSON, Leif e MALONE, Michel. S. Capital Intelectual: Descobrindo o valor real de sua empresa pela identificação de seus valores internos. São Paulo: Makron Books, 1998.

ELLINOR, Linda; GERARD, Glenna. Dialogue: Rediscover the Transforming Power of Conversation. NewYork: John Wiley \& Sons, 1998.

EISENHARDT, Joseph P. Ensino Jurídico: diagnóstico, pesquisa e metodologia. Brasília: T.A. Queiroz, 1991.

ENRIQUEZ, Eugène. A Organização em Análise. Petrópolis: Vozes, 1997.

FAZENDA, Ivani C. A. Interdisciplinaridade - Um projeto de parceria. São Paulo: Loyola: 1991.

, Interdisciplinaridade: qual o sentido?. São Paulo: Paulus, 2003. 
FERNANDES, Alina; GUIMARÃES, Flávio Romero; BRASILEIRO, Maria do Carmo Eulálio (Org.). O Fio que une as pedras: a pesquisa interdisciplinar na pós- graduação. São Paulo: Biruta, 2002.

FERNANDES, Bruno Henrique Rocha. Competências \& Desempenho Organizacional: O que há além do Balanced Scorecard. São Paulo: Saraiva, 2006

FERREIRA, Aurélio. Novo Dicionário Aurélio da Língua Portuguesa. Rio de Janeiro: Editora Nova Fronteira.

FISCHER, André Luiz. O Conceito de Modelo de Gestão de Pessoas - Modismo e Realidade em Gestão de Recursos Humanos nas Empresas Brasileiras (Introdução) in Gestão por Competências: um modelo avançado para gerenciamento de pessoas/ organizador e autor Joel Souza Dutra [et. al.]. São Paulo: Editora Gente, 2001.

Cap. 1- Um resgate conceitual e histórico dos modelos de gestão

de Pessoas in As pessoas na Organização / Maria Tereza Fleury [et al.]. São Paulo: Gente, 2002.

FLEURY André e FLEURY Maria Tereza Leme. Estratégias Empresariais e Formação de Competências: um quebra-cabeça caleidoscópio da Indústria Brasileira. São Paulo: Atlas, 2001.

FLEURY Maria Tereza Leme e FISCHER, Rosa Maria. Relações de Trabalho e Políticas de Gestão: uma história das questões atuais. Revista de Administração- USP, v.27, nº4, out/ dez, 1992.

, (Coord.). Cultura e Poder nas Organizações. São Paulo: Atlas,1996.

, (Coord.). As Pessoas na Organização. São Paulo: Gente, 2002.

FREITAS, Sidinéia Gomes. A comunicação social como instrumento do poder. As coordenadorias de comunicação social na “Nova República”. Tese de Doutorado na Escola de Comunicações e Artes da Universidade de São Paulo, 1987.

Cap.4: Cultura organizacional e comunicação in Obtendo Resultados com Relações Públicas / Margarida Maria Krohling Kunsch (org.). São Paulo: Pioneira Thomson Learning, 2006.

FREITAS, Sidinéia Gomes e FRANÇA, Fabio. Manual da Qualidade em Projetos de Comunicação. São Paulo: Pioneira, 1997.

FREUD, Sigmund. O Mal - Estar na Civilização. Rio de Janeiro: Imago, 1997.

FROMM, Eric. Análise do Homem. Rio de Janeiro: Zahar, 1968.

GARDNER, Howard. Mentes que criam: Uma anatomia da criatividade observada através das vidas de Freud, Einstein, Picasso, Stravinsky, Eliot, Graham e Gandhi. Porto Alegre: Artes Médicas, 1996.

GENTILI, Pablo Silva, T. (Org.). Pedagogia da exclusão: crítica ao neoliberalismo em educação. Petrópolis:Vozes, 1995.

GENTILI, Pablo SILVA, T. (Org.). Neoliberalismo, qualidade total e educação. Petrópolis: Vozes, 1994.

GEERTZ, Clifford. O saber Local: novos ensaios em antropologia interpretativa. São Paulo: Vozes, 1999.

, Gestão de Pessoas: Enfoque nos Papéis Profissionais. São Paulo: Atlas, 2001. 
GODOY, Arilda S. Introdução á pesquisa qualitativa e suas possibilidades. Revista de Administração de Empresas, Rio de Janeiro, v.35, n.2, p.57-63, abr./mar, 1995.

GOFFMAN, Erving. A Representação do Eu na Vida Cotidiana. Petrópolis: Vozes, 1975.

GOLEMAN, Daniel. Inteligência Emocional. Rio de Janeiro : Objetiva, 1996.

GOMES- MEJIA, Luis R. ; BALKIN David B; CARDY, Robert L. Managing Human Resourses. Upper Saddle River, New Jersey: Prentice- HALL, 2001.

GRAMIGNA, Maria Rita. Modelo de Competências e Gestão de Talentos. São Paulo: Makron Books, 2002.

GREENBERG, David F. Autonomous Group Functioning. Londres: Tavistock, 1975.

GUTIERREZ, L.H.S. Enfoque Estratégico da função recursos humanos. Revista de Administração de Empresa. São Paulo: FGV, V.31 nº, p.63-74, out/dez 1991.

HABERMAS, Jurgen. O Discurso Filosófico da Modernidade. São Paulo: Martins Fontes, 2002.

Brasileiro, 2003.

Consciência Moral e Agir Comunicativo. Rio de Janeiro Tempo , Theory and Practise. Boston: Beacom Press, 1973.

, Teoria De La Acion Comunicativa. Tomo I Racionalidade de la acion y racinalizacion social .Madri: Taurus, 1987.

Teoria De La Acion Comunicativa. Tomo II Critica de la razón funcionalista. Madri: Taurus, 1987.

HAMEL, Gary e PRAHALAD, C. K. Competindo pelo Futuro: Estratégias inovadoras para obter o controle de seu setor e criar os mercados de amanhã. Rio de Janeiro: Campus, 1995.

HANASHIRO, Darcy Mitiko Mori; TEIXEIRA, Maria Luisa Mendes; ZACCARELI, Laura Meneon (Organizadoras) [at al.]. Gestão do Fator Humano: uma visão baseada em stakeholders . São Paulo: Saraiva, 2007.

HANDY, Carl. The age of Unreason. Londres: Business Books, 1991.

HATHCOCK, B. C. The New- Bread Aproach to 21st Century Human Resources. Human Resources Management, vol.35, Number 2, 1996.

HELOANI, Roberto. Gestão e Organização no Capitalismo Globalizado: História da Manipulação Psicológica no Mundo do Trabalho. São Paulo: Atlas, 2003.

São Paulo: Cortez, 1994.

Organização do trabalho e administração: uma visão multidisciplinar.

A Identidade do Psicólogo do Trabalho em Tempos de globalização. In: Cadernos de Psicologia Social do Trabalho, Universidade de São Paulo, Instituto de Psicologia, 2(1), p.39-54, 1999.

HOHLFELDT, Antonio, MARTINO, Luiz C. e FRANÇA, Vera Veiga. Teorias da Comunicação: Conceitos, escolas e tendências. Petrópolis: Vozes, 2002.

IANNI, Octavio. Enigmas da Modernidade- Mundo. Rio de Janeiro: Civilização Brasileira, 2000 .

, A Sociedade Global. Rio de Janeiro: Civilização Brasileira, 2002. 
JABLIN, Frederic M. ; PUTNAM, Linda L. The Handbook of Organizational Communication: Advances in Theory, Research, and Methods / edited by Frederic M. Jablin and Linda L. Putnam. Thousand Oaks, California: Sage Publications, 2000.

KANAANE, Roberto. O Comportamento Humano nas Organizações: O Homem Rumo ao Século XXI. São Paulo: Atlas, 1999.

KOTTER, John P. O Fator Liderança. São Paulo: Makron, McGraw-Hill, 1992.

KREPS, G.L. Organizational Communication. Longman Group LTD, Londres , Inglaterra, 1990.

KRONE Kathleen J. JABLIN Frederic M. ; PUTNAM Linda L. Communication Theory and Organizational Communication: Multiple Perspectives (c.1) in Handbook of Organizational Communication. An Interdisciplinary Perspective / Editors: Frederic M. Jablin, Linda L. Putnam, Karlene H. Roberts, Lyman W. Porter . Newbury Park, California: Sage Publications, 1982.

KUNSCH, Margarida Maria Krohling. Planejamento de Relações Públicas na Comunicação Integrada. São Paulo: Summus, 2003.

, Relações Públicas e Modernidade: novos paradigmas na comunicação organizacional. São Paulo: Summus, 1997.

Thomson Learning, 2006.

(org.) Obtendo Resultados com Relações Públicas. São Paulo: Pioneira

LACOMBE, Francisco José Masset. Recursos humanos: princípios e tendências. São Paulo: Saraiva, 2005.

LAFER, Celso. A Reconstrução dos Direitos Humanos: Um Diálogo com o Pensamento de Hannah Arendt. São Paulo: Companhia das Letras, 1999.

LANNES, L. S. Equipes Auto- Gerenciáveis e a Forma de Organização de Trabalho Adequada a sua Implantação. São Paulo: Monografia de conclusão do Curso de MBA apresentada a FEA/ USP, 1999.

LE BOTERF, Guy. Desenvolvendo a competências dos profissionais. Porto Alegre: Artmed, 2003.

LEBOYER, Claude L. Gestion delas competências.Barcelona: Adiciones Gestión 2000, 1997.

LEFEBVRE, Henri. Sociologia de Marx. Rio de Janeiro: Forense, 1968.

LIBANIO, João Batista. A Arte de Formar-se. São Paulo: Loyola, 2002.

LUKÁCS, Gyorgy. Cap. 1: A Consciência de Classe in Estrutura de Classes e Estratificação Social/ organização e tradução de Antonio Roberto Bertelli, Moacir G. Soares Palmeira, Otávio Guilherme C. A. Velho. Rio de Janeiro: Zahar, 1973.

MARCELLINO, Nelson Carvalho (Org.) Introdução às Ciências Sociais. Campinas: Papirus, 2001.

MACARENCO, Isabel; DAMIÃO, Maria de Lurdes Zamora. Inclusão da CHAVE como Estratégia na Gestão de Pessoas. Revista Eletrônica Correlatio- $\mathbf{n}^{\circ} 10$ www.metodista.br/correlatio. 2006 
MARCHIORI, Marlene R. Cultura Organizacional: Conhecimento Estratégico nos Relacionamentos e na Comunicação com os Empregados. Tese de Doutorado Sob Orientação Prof ${ }^{a}$ Dra Sidinéia Gomes Freitas, apresentada à Escola de Comunicação e Artes da Universidade de São Paulo, 2001.

MARCONI, M. A. e LAKATOS, E. M. Técnicas de Pesquisa. São Paulo: Atlas, 2002.

MARIOTTI, Humberto. Organizações de Aprendizagem: educação continuada e a empresa do futuro. São Paulo: Atlas, 1999.

O Automatismo Concordo-discordo e as Armadilhas do Reducionismo. Instituto de Estudos de Complexidade e Pensamento Sistêmico (www.pluriversu.org),2000.

MARRAS, Jean Pierre. Administração de Recursos Humanos: Do operacional ao estratégico. São Paulo: Futura, 2000.

MARX, Karl. O capital: Crítica da Economia Política. Livro Primeiro: O processo de Produção do Capital. Volume I. Rio de Janeiro: Civilização Brasileira, 1971.

MASCARENHAS, André Ofenhejm; VASCONCELOS, Flavio Carvalho. Gestão de Pessoas: Estratégias de auto-atendimento para o Novo RH. São Paulo: Pioneira Thomson Learning, 2004.

MASLOW, Abraham H. Motivation and Personality. USA: Longman, 1987.

MATTERLART, Armand; MATTERLART, Michele. História das Teorias da Comunicação. São Paulo: Loyola, 2003.

MAXIMIANO, Antonio César Amaru. Teoria Geral de Administração. São Paulo: Atlas, 2000.

,Teoria Geral de Administração. São Paulo: Atlas, 2002.

MAYO, Andrew. O Valor Humano da Empresa: Valorização das Pessoas como Ativos. São Paulo: Prentice Hall, 2003.

MIÈGE, Bernard. O Pensamento Comunicacional. Petrópolis, RJ: Vozes, 2000.

MINAYO, Maria Cecília de Souza. QUANTITATIVO \& QUALITATIVO: OPOSIÇÃO OU COMPLEMENTARIDADE ? Cadernos de Saúde Pública, RIO DE JANEIRO, v. IX, n. 3, p. 239-262, 1993.

MORAES, D. A. F. Método de Gestão por competência para melhoria da qualidade do processo de recrutamento e seleção de profissional. Universidade Estadual de Campinas, Faculdade de Engenharia Mecânica. Dissertação de Mestrado sob a orientação de Dr. Ettore Bresciani Filho, 2003.

MORGAN, Gareth. Imagens da Organização. São Paulo: Atlas, 2000.

MORIN, Edgar. A Cabeça Bem Feita: repensar a reforma, reformar o pensamento. Rio de Janeiro: Bertrand Brasil, 2000.

Brasília, DF: Unesco, 2000.

Os Sete Saberes Necessários à Educação do Futuro. São Paulo: Cortez, Ciência com Consciência. Rio de Janeiro: Bertrand Brasil, 1996.

MOTTA, Fernando C. Prestes. Organizações: Vínculo e Imagem. Revista de Administração de Empresas. São Paulo, 31 (3): 5-11, Jul./Set. 1991. 
NONAKA, Ikujiro e TAKEUCHI, Hirotaka. Criação de Conhecimento na Empresa: Como as Empresas Japonesas Geram a Dinâmica da Inovação. Rio de Janeiro: Campus, 1997.

OLIVEIRA, Lucia Lippi, FERREIRA; Marieta de Moraes; CASTRO, Celso (Org.) Conversando com ...... Giddens, Ginzburg, Hobsbawm, Furet, Becker, Le Goff, Revel, Morse, Darnton, Donghi e Dean . Rio de Janeiro: FGV, 2003.

PAGÉS, Max. (et al.). O Poder das Organizações. São Paulo: Atlas, 1987.

PALOMINO, Roberto. Nem acaso, nem Milagre - A Gestão do Compromisso. São Paulo: Gente, 1997.

PERRENOUD, Philippe [et. al.]. As competências para Ensinar no século XXI. Porto Alegre: Artmed, 2002.

POCHMANN, Marcio. O Emprego na Globalização. São Paulo: Boitempo, 2001.

PRICE WATERHOUSE. Equipe de Change Integration. Princípios de Paradoxos: Como empresas de Alto Desempenho Administram o Caos, a Complexidade e a Contradição para Atingir Resultados Superiores. São Paulo: Atlas, 1999.

PUTNAM, Linda 1.; PHILLIPS; Nelson; CHAPMAN, Pamela. Cap 3: Metáforas da Comunicação e da Organização in: Handbook de estudos organizacionais (v.3)/ organizadores da edição original Stewart R. Clegg, Cynthia Hardy, Walter R. Nord; Miguel Caldas, Roberto Fachin, Tânia Ficher organizadores da edição brasileira. São Paulo: Atlas, 2004.

REGO, Francisco Gaudêncio Torquato do. Comunicação Empresarial: comunicação institucional, conceitos, estratégias, sistemas, estrutura, planejamento e técnicas. São Paulo: Summus, 1986.

Tratado de Comunicação Organizacional e Política. São Paulo: Pioneira Thomson Learning, 2002.

REIS, Germano Glufke. Avaliação $\mathbf{3 6 0}^{\circ}$ : um instrumento de desenvolvimento gerencial. São Paulo: Atlas, 2003.

RIBEIRO, Antonio de Lima. Gestão de Pessoas. São Paulo: Saraiva, 2006.

ROBBINS, Stephen Paul. Fundamentos do Comportamento Organizacional: tradução técnica Reinaldo Marcondes. São Paulo: Prentice Hall, 2004.

ROCHA, Silvia Renata Medina. Cap.3: Convivencialidade: Será que Estamos Preparados? in Convivencialidade: A Expressão da Vida nas Empresas / organizadores Márcia Esteves Agostinho, Ruben Bauer, José Predebon. São Paulo: Atlas, 2002.

RUIZ, J.A. Metodologia científica: guia para eficiência nos estudos. São Paulo: Atlas, 1979.

SANTOS, Fernando César Almada. Estratégia de Recursos Humanos: Dimensões Competitivas. São Paulo: Atlas, 1999.

SCHIRATO, Maria Aparecida Rhein Schirato. O Feitiço das Organizações: sistemas imaginários. São Paulo:Atlas,2000.

SCHULTZ, Theodore. O capital humano. Rio de Janeiro: Zahar, 1973.

SEAGAL, Sandra; HORNE, David. Human Dynamics: um Novo Contexto para Compreender Pessoas e Realizar o Potencial de Nossas Organizações. Rio de Janeiro: Quality Mark, 2004. 
SELLTIZ, Celso [et. al.]. Métodos de pesquisa nas relações sociais. São Paulo: Herder, 1987.

SENGE, Peter M. A Quinta Disciplina. São Paulo: Best Seller, 2004.

SENNETT, Richard. A Corrosão do Caráter: as conseqüências pessoais do trabalho no novo capitalismo; tradução Marcos Santarrita. Rio de Janeiro: Record, 2003.

SILVA, Reinaldo Oliveira. Teorias da Administração. São Paulo. Pioneira Thomson Learning, 2001.

SIMÕES, Luiz G. Reestruturação Produtiva e Recursos Humanos: Tendências e Impactos. Universidade Estadual de Campinas- Faculdade de Educação. Dissertação de Mestrado sob orientação do Prof. ${ }^{\circ}$ Dr. José Roberto Heloani, 2001.

SOUZA FILHO, Severino Gomes. Cap. 5: Comunicação e Interdisciplinaridade in O Fio que une as pedras: a pesquisa interdisciplinar na pós-graduação. São Paulo: Biruta, 2002.

STAKE, R. E. The Art of case study research. USA: Sage Publications Ltda, 1994.

STEWART, Thomas. Capital Intelectual: a nova vantagem competitiva das empresas. Rio de Janeiro: Campus, 1998.

TOSE, Marília de Gonzaga Lima e Silva. A evolução da gestão de recursos humanos no Brasil. Dissertação de Mestrado na Faculdade de Administração da Pontifícia Universidade Católica- PUC/ SP, 1997.

TEIXEIRA, Maria Luiza Mendes e ZACCARELLI, Laura Menegon. Cap.4: Os desafios da Atuação Socialmente Responsável in Gestão do Fator Humano: uma visão baseada em stakeholders / organizadoras Darcy Mitiko Mori Hanashiro, Laura Menegon Zaccarelli e Maria Luisa Mendes Teixeira; Arilda Schimidt Godoy...[at al.].- São Paulo: Saraiva, 2007.

TERRA, José Cláudio Cyrineu, Gestão do Conhecimento - O grande desafio empresarial. São Paulo: Negócio, 2000.

THUROW, Lester C. O Futuro do Capitalismo: Como as Forças Econômicas Moldam o Mundo de Amanhã; tradução de Nivaldo Montingelli Jr. Rio de Janeiro: Rocco, 1997.

TOMPKINS, PHILlIP K; THIBAULT, Maryanne Wanca. Prelude an Prospects: Comunicação Organizacional in The Handbook of Organizational Communication: Advances in Theory, Research, and Methods / edited by Frederic M. Jablin and Linda L. Putnam. Thousand Oaks, California: Sage Publications, 2000.

TOURAINE, Alan. Crítica da modernidade. Petrópolis: Vozes, 1994.

ULRICH, David (Org.). Recursos Humanos Estratégicos: Novas Perspectivas para os Profissionais de RH. São Paulo: Futura, 2000.

VASCONCELOS, Flavio Carvalho de e VASCONCELOS, Isabella Freitas Gouveia de. Paradoxos Organizacionais: Uma visão transformacional. São Paulo: Pioneira Thomson Learning, 2004

VAN PARIJS, Philippe. O que é uma Sociedade Justa?. São Paulo: Ática, 1997.

WEBER, Max. Ensaios de Sociologia. Rio de Janeiro: Guanabara, 1982.

WEISINGER, H. Inteligência Emocional no Trabalho. Rio de Janeiro: Objetiva, 1997.

VERGARA, Sylvia Constant. Gestão de Pessoas. São Paulo: Atlas, 2003.

WOOD JR, Thomaz. Administração Estratégica e Administração de Recursos Humanos. Revista de Administração da USP, São Paulo, v.27, nº 4, out/dez, 1992. 
A volta da teoria X . Revista Carta Capital. Edição 06/04/2005, nº336 ano

XI e pág 37

Remuneração por Habilidades e Competências: Preparando a Organização para a Era da Empresas de Conhecimento Intensivo. São Paulo: Atlas, 1997.

, (coord.). Gestão Empresarial: O Fator Humano. São Paulo: Atlas, 2002.

ZACCARELLI, Laura Menegon; DE DOMENICO, Silvia Márcia Russi; TEIXEIRA, Maria Luiza Mendes. Cap.6: O outro lado da Moeda: desenvolvendo a Empregabilidade e a Carreira in Gestão do Fator Humano: uma visão baseada em stakeholders/ organizadoras Darcy Mitiko Mori Hanashiro, Laura Menegon Zaccarelli e Maria Luisa Mendes Teixeira; Arilda Schimidt Godoy...[at al.]. São Paulo: Saraiva, 2007.

ZAMPOLO, Almir. A múltipla percepção dos elementos de auto gestão em uma instituição religiosa. Tese de Doutorado sob orientação do Prof ${ }^{\circ}$ Dr Antonio César Amaru Maximiano, apresentada à Faculdade de Economia e Administração da Universidade de São Paulo, Junho de 2004.

ZARIFIAN, Philippe. Objetivo Competência. São Paulo: Atlas, 2001.

Cap. 5: Comunicação e Subjetividade na Organizações in Gestão

com Pessoas e Subjetividade/ Eduardo Davel; Sylvia Constant Vergara (organizadores). São Paulo: Atlas, 2001.

\section{SITES}

http://www.convivencialidade.org.br, acessado em 10 de dezembro de 2006.

http://www.conviver.org.br ,acessado em 10 de dezembro de 2006.

ÍNDICE DE DESENVOLVIMENTO HUMANO. Disponível em http://pt.wikipedia.org/wiki/\%C3\%8Dndice_de Desenvolvimento_Humano, acessado em 12/outubro de 2006.

www.uol.com.br/houaiss, acessado em 23/08/2004 - 13h16.

http://michaelis.uol.com.br/moderno/portugues/index.php?palavra=conviver, acessado em 24 de abril de 2005.

http://www.pluriversu.org- Instituto de Estudos de Complexidade e Pensamento Sistêmico, acessado em 10 de dezembro de 2006. 


\section{GLOSSÁRIO}

Abertura à experiência- Uma característica de personalidade que indica uma tendência a imaginação, curiosidade e mente aberta.

Administração- Significa a maneira de governar organizações ou parte delas. É o processo de planejar, organizar, dirigir e controlar o uso de recursos organizacionais para alcançar determinados objetivos de maneira eficiente e eficaz.

Administração de Recursos Humanos ou Administração de RH- Refere-se às práticas e às políticas necessárias para conduzir os aspectos relacionados às pessoas no trabalho de gerenciamento, especificamente à contratação, ao treinamento, à avaliação, à remuneração e ao oferecimento de um ambiente bom e seguro aos funcionários. Todos os gerentes são, de algum modo, gerentes de RH, uma vez que precisam se envolver em atividades como seleção, entrevistas, avaliação e treinamentos.

ARH ou área de RH ou RH ou Departamento de Recursos Humanos- Funda-se nas tradições da psicologia industrial, das teorias organizacionais, da abordagem sócio-técnica, da dinâmica de grupos, entre outras. A ARH tem por princípio aumentar a produtividade e favorecer a busca pela vantagem competitiva da empresa.

Administrar- Gerir, dirigir e manter sob controle, um grupo

Afinidade- É o sentimento de agrado ou outra atitude emocional.

Aprendizagem- $\mathrm{O}$ modo como os seres adquirem novos conhecimentos, desenvolvem competências e mudam o comportamento. Contudo, a complexidade desse processo dificilmente pode ser explicada apenas através de recortes do todo. Por outro lado, qualquer definição está, invariavelmente, impregnada de pressupostos político-ideológicos, relacionados com a visão de $\underline{\text { homem}}, \underline{\text { sociedade e saber. }}$

Avaliação de Desempenho- É a ferramenta utilizada para melhorar os resultados dos recursos humanos da organização, objetivando a adequação do indivíduo ao cargo, treinamento correto, incentivo salarial entre outros. 
Avaliação $\mathbf{3 6 0}^{\circ}$ - Reconhecido como um processo que expande a avaliação de performance individual, é um processo de feedback que pode, se responsavelmente aplicado e dentro dos limites a que está sujeito, motivar para a criação de um ambiente favorável aos relacionamentos, à troca de experiências, ao atingimento de resultados e principalmente ao desenvolvimento organizacional.

Auscultação- É uma etapa do processo de transformação organizacional e refere-se ao mapeamento e análise de projetos de aperfeiçoamento organizacional já existentes na organização, para verificar a possibilidade de adequá-los e integrá-los ao processo de transformação em delineamento.

Capital Humano- É um conjunto de conhecimentos, treino e capacidades das pessoas, que lhes permitem realizar trabalhos úteis com diferentes graus de complexidade e especialização.

Capital Intelectual- Manifesta-se em todas as ações da vida, nas decisões e até mesmo na sobrevivência da espécie humana. O termo teve sua origem na propriedade intelectual; os componentes de conhecimentos de uma empresa, reunidos e legalmente protegidos.

Coaching- é uma palavra francesa antiga que significa "um veículo para transportar pessoas de um lugar para o outro". Atualmente, um coach ajuda uma pessoa a galgar um nível - ao expandir uma aptidão, aumentar a performance ou até ao mudar a forma como a pessoa pensa. Os coaches ajudam as pessoas a crescerem. Eles ajudam as pessoas a verem além do que são hoje para o que elas querem tornarem-se amanhã. É realizado quando a organização contrata alguém especializado com o objetivo de implantar ou rever seus Sistemas de Gestão e Aconselhamento de Carreiras.

Competência de apoio- Serve para firmar ou sustentar as ações profissionais.

Competência individual- É “o tomar iniciativa" e "o assumir responsabilidade" do indivíduo diante de situações profissionais e pessoais, com os quais se depara. A competência é assumida, pois resulta de uma postura pessoal de ter vontade de assumir uma situação e ser responsável por ela. A mobilização da competência é levada a efeito pela expressão desse interesse. 
Complexidade- Quer dizer diversidade, convivência com o aleatório, com mudanças constantes e com a conflituosidade, e ter de lidar com tudo isso mobilizando potenciais criadores e transformadores.

Comunicação- Como intercâmbio de idéias entre dois ou mais indivíduos de modo que as idéias possam ser duplicadas. Uma linguagem básica para que as idéias sejam entendidas.

Confronto- Fazer face sem evitar o contato. É a capacidade de estar ali e perceber.

Conhecimento- Pode ser obtido pelo estudo, pela pesquisa e pela observação sistemática. Pode-se falar em aquisição de conhecimento, produção de conhecimento, acumulação de conhecimento. $\mathrm{O}$ fato de ser acumulável faz com que ele seja até certo ponto controlável pelos os que o acumularam. O conhecimento é uma forma de capital, já conhecida pelos economistas desde o século XVIII.

Convivencialidade- Define-se como uma atitude de indivíduos ou de instituições de reconhecerem a si mesmos no outro (indivíduos,instituições, mercado, sociedade, natureza), estabelecendo pela identificação de um senso de integração que se desdobra em respeito, abertura e cuidado, não permitindo reduzir esse outro a objeto ou instrumento para consecução de interesses próprios.

Cultura de uma organização- É um sistema de valores e crenças compartilhados e que determinam os comportamentos dos que o compartilham. O conceito inclui a idéia de interação, de relação entre as pessoas e as múltiplas maneiras de relacionamento.

Dimensão do Ser- O homem é um “ser-no-mundo", e, nesse mundo, existe em relação a seus semelhantes. O mundo é a realidade humana. O homem habita o mundo e constrói/destrói um ambiente relacionado a ele próprio

Dimensões do ser humano- Pensar (dimensão de valores); Sentir (dimensão interpessoal e social) e Agir (dimensão prática).

Efetividade- É realizar a coisa certa para transformar a situação existente. 
Eficácia- É a capacidade de realizar objetivos.

Eficiência- É utilizar produtivamente os recursos.

Empregabilidade- É um termo relativamente recente, derivado do inglês employability e sua inserção no vocabulário empresarial está relacionada às mudanças nas relações de trabalho. A empregabilidade seria a capacidade de tornar-se empregado, de conseguir emprego e numa definição mais ampliada é a capacidade humana de obter trabalho e renda.

Gestão- Ato de gerir, gerência, administração

Incerteza- Condição para tomada de decisão na qual os administradores enfrentam situações externas imprevisíveis ou não têm informações necessárias para estabelecer a probabilidade de determinados eventos.

Informação- É um conjunto de dados, fatos ou notícias veiculados pelos meios de comunicação e que de nada vale sem que se tome consciência dela.

Instituição- É o conjunto de idéias que regulam a vida humana com base em valores que se traduzem em normas, regras e leis.

Inteligência- É um quesito que se tornou particularmente importante neste final de século e refere-se a uma capacidade exigida para as mais qualificadas funções no mercado de trabalho e, assim, fundamenta um poderoso mecanismo de legitimação da exclusão social ao permitir que se estabeleçam diferenças entre quem possui e quem não possui qualificação intelectual para o trabalho.

Inteligência criadora- Revela a capacidade de pensar, muito mais do que uma atitude passiva diante da realidade que se busca conhecer, é uma atitude ativa, de quem vai ao encontro da realidade, de maneira criativa, buscando a melhor maneira de exprimi-la, tal como é vivida na originalidade de cada pessoa, dadas as circunstâncias particulares e até certo ponto únicas, em que se acha inserida. 
Interdisciplinaridade- Nesse caso, várias disciplinas se reúnem e interagem. Há correlação e integração entre elas, o que permite que daí surja uma síntese, que se manifesta por uma nova expressão, diferente das linguagens das disciplinas separadas. Aqui existe sinergia, o todo é maior que a soma de suas partes.

Lei de Causa e Efeito- "Toda causa tem seu efeito, todo o efeito tem sua causa, existem muitos planos de causalidade, mas nenhum escapa à Lei". Nada acontece por acaso, pois não existe o acaso, já que acaso é simplesmente um termo dado a um fenômeno existente e do qual não conhecemos a origem, ou seja, não reconhecemos nele a Lei à qual se aplica.

Lei da polaridade- "Tudo é duplo, tudo tem dois pólos, tudo tem o seu oposto. O igual e o desigual são a mesma coisa. Os extremos se tocam. Todas as verdades são meias-verdades. Todos os paradoxos podem ser reconciliados" - (O Caibalion). A polaridade revela a dualidade, os opostos representando a chave de poder no sistema hermético. Mais do que isso, os opostos são apenas extremos da mesma coisa. Tudo se torna idêntico em natureza. O pólo positivo + e o negativo - da corrente elétrica são uma mera convenção. O claro e o escuro também são manifestações da luz. A escala musical do som, o duro versus o flexível, o doce versus o amargo. Amor e o ódio são simplesmente manifestações de uma mesma coisa, de diferentes graus de um sentimento.

Medo- É sempre o medo de crescer, de amadurecer, de ter de decidir sobre o próprio destino, sem tutelas ou protecionismo.

Mudança- Sempre foi a tônica da civilização. Em busca de alimento, abrigo, segurança e adaptação climática, os primeiros habitantes mudavam seu habitat ou de local. A construção das cidades, da sociedade e do mundo como se conhece hoje é fruto de muitas experiências bem e mal sucedidas. Para tudo isso o homem precisou rever sua forma de agir e interagir como meio. Necessitou mudar seu comportamento, suas atitudes, seus pensamentos, suas crenças e suas idéias e no mundo corporativo não é diferente. Atinge o sucesso aquele que, diante das mudanças, atua como agente de transformação, cria, pensa soluções inovadoras para os mais variados problemas organizacionais.

Mudança de paradigma- Uma mudança profunda no pensamento, na percepção e valores que forma uma determinada visão da realidade. 
Organização- É a instituição em funcionamento, materializada.

Outro- Um ser real que tem desejos, pensamentos e sentimentos. Compreender sobre o outro implica sair da postura vertical, em que alguém tem de ser melhor que o outro, e cair na horizontalidade.

Paradigma- São referenciais que se usa para balizar as decisões; são lentes usadas por um indivíduo e que condicionam a sua visão de mundo, dando-lhe cores e formas. Consideram-se paradigma as realizações científicas universalmente reconhecidas que, durante algum tempo fornecem problemas e soluções modulares para uma comunidade de praticantes de uma crença.

Paradoxo- É uma declaração aparentemente verdadeira que leva a uma contradição lógica, ou a uma situação que contradiz a intuição comum. Em termos simples, um paradoxo é 'o oposto do que alguém pensa ser a verdade'. A identificação de um paradoxo baseado em conceitos aparentemente simples e racionais tem, por vezes, auxiliado significativamente o progresso da ciência, filosofia e matemática.

Profissionais de Recursos Humanos- Atuam tradicionalmente no planejamento e gerenciamento dos subsistemas de gestão de pessoas, tais como recrutamento e seleção, cargos e salários, treinamento e desenvolvimento, avaliação de desempenho, rotinas de pessoal, benefícios, gestão de carreiras e sistema de informação de recursos humanos. Esse profissional promove o desenvolvimento de competências relacionadas ao comportamento nos níveis individual (motivação), de grupo (negociação, liderança, poder e conflitos) e organizacional (cultura, estrutura e tecnologias), catalisando os processos de elaboração de planejamento estratégico, programas de qualidade de vida do trabalho e avaliação do clima organizacional.

Qualidade Total- É uma filosofia de administração que volta toda a empresa para a missão de satisfazer as necessidades de seus clientes com excelência.

Racionalidade- É o resultado do diálogo constante entre a mente e o mundo real. 
Racionalização- Procura reduzir o mundo real ao que foi convencionado. Racionalizar significa querer que o real se enquadre num modelo de pensamento fragmentador, linear e reducionista.

Realidade- Aquilo que parece ser. A realidade é um acordo sobre um conjunto de percepções, relacionamentos e realizações das pessoas.

Recursos Humanos- É o conjunto de colaboradores ou empregados de uma organização. Refere-se ao quadro funcional que vai desde a mais simples função até o presidente e são os recursos humanos os responsáveis pela consecução das metas organizacionais

R.E.D.E.- Rede para a Educação, o Dom e a Expressão é uma comunidade auto- organizante dedicada a promover, divulgar, disseminar e fomentar a convivencialidade nas empresas, para que nelas se desenvolva a expressão dos potenciais humanos. Site http://www.convivencialidade.org.br

Roda- Para entender a roda é necessário compreender primeiro que a ignorância é uma forma de prisão do indivíduo e enfrentá-la é a parte mais difícil de aprendizado. A ignorância é muitas vezes percebida como um porto seguro, pois revela uma sensação de solidez, de nenhum movimento ou necessidade de transformação.

Sabedoria- Não pode ser obtida pelo estudo e aflora pela experiência vivida. Trata-se do modo de usar o conhecimento e a tecnologia para atingir e manter uma boa qualidade de vida.

Ser convivencial- Considera-se que todos são iguais em essência, com diferença no grau de percepção da humanidade de cada um e ser convivencial com o outro é respeitá-lo, onde ele está na sua caminhada de evolução.

Stakeholders- É qualquer grupo de indivíduos que afeta, ou pode ser afetado, pela realização e alcance dos objetivos organizacionais. Os stakeholders primários são aqueles com os quais a empresa mantém um relacionamento contratual e compreendem os acionistas, os investidores, os empregados, os fornecedores, os clientes e os que fazem cumprir leis e regulamentações; os secundários referem-se aos demais grupos da sociedade. 
Ser humano na tomada de decisão- É muito complexo, as suas necessidades, incertezas, valores, desejos, etc., individualmente ou em conjunto, influenciam o processo de tomada de decisão, levando por vezes a uma decisão de qualidade inferior em prol de um necessidade ou desejo.

Subjetividade- É considerada no estudo das pessoas nas organizações de modo a tornar compreensível a experiência humana em sua fonte mais complexa, rica e profunda. Designa a interioridade da pessoa e é expressa em pensamentos, condutas, emoções e ações. A subjetividade deve ser concebida como um fenômeno posicional e contingente em que o indivíduo não pode ser considerado unificado ao longo de tempo.

Teoria X - de Douglas McGregor- Define a forma como os gestores percebem a motivação dos funcionários e estabelecem sua abordagem gerencial. Apresenta os seguintes pressupostos: o trabalho é desagradável para a maioria dos indivíduos e eles tentam evitá-lo sempre que possível; a capacidade criativa e a iniciativa para resolver problemas organizacionais são características incomuns e a maioria das pessoas não deseja ter responsabilidades, por isso, deve ser controlada.

Terceira Onda- Identificada por Toffler em 1980, mostra que a Era do conhecimento permite uma grande descentralização de tarefas. Esta fase é caracterizada pelo poder do cérebro, na qual a informação assume o papel de principal recurso econômico.

Tomada de decisão- Pode ser definido como sendo a escolha, entre duas ou mais alternativas de ação, que possibilitem o resultado esperado. Tem por base a existência de um conjunto de critérios dentre os quais se encontram os valores do próprio tomador de decisão e o peso que cada valor adquire em cada momento ou em cada situação. A situação ideal para tomada de decisão é sem pressões, nem condicionamentos, onde o que prevalece é a melhor das alternativas encontradas para a resolução do problema.

Utilitarismo- É quando a empresa dispõe das pessoas, ignorando suas individualidades. Para consigo mesmo é a ausência de um projeto de vida. 
Visão- Orienta e delimita a ação da empresa definindo a que ela se propõe, a razão de sua existência, deve contemplar clientes finais, intermediários e internos, fornecedores, a sociedade, todos aqueles que estão envolvidos com as atividades da empresa. 